\title{
ANALYSIS OF POTENTIAL COMBUSTION SOURCE IMPACTS ON ACID DEPOSITION USING AN INDEPENDENTLY DERIVED INVENTORY
}

Volume I

December 1983

Work Performed Under Contract No.: DE-AC21-82MC19285

For

U. S. Department of Energy

Office of Fossil Energy

Morgantown Energy Technology Center

Morgantown, West Virginia

By

PEDCo Environmental, Inc.

Cincinnati, Ohio

and

Paul W. Spaite Co.

Cincinnati, Ohio

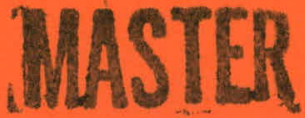

TECHNICAL INFORMATION CENTER OFFICE OF SCIENTIFIC AND TECHNICAL INFORMATION UNITED STATES DEPARTMENT OF ENERGY 


\section{DISCLAIMER}

This report was prepared as an account of work sponsored by an agency of the United States Government. Neither the United States Government nor any agency Thereof, nor any of their employees, makes any warranty, express or implied, or assumes any legal liability or responsibility for the accuracy, completeness, or usefulness of any information, apparatus, product, or process disclosed, or represents that its use would not infringe privately owned rights. Reference herein to any specific commercial product, process, or service by trade name, trademark, manufacturer, or otherwise does not necessarily constitute or imply its endorsement, recommendation, or favoring by the United States Government or any agency thereof. The views and opinions of authors expressed herein do not necessarily state or reflect those of the United States Government or any agency thereof. 


\section{DISCLAIMER}

Portions of this document may be illegible in electronic image products. Images are produced from the best available original document. 


\title{
DISCLAIMER
}

\begin{abstract}
This report was prepared as an account of work sponsored by an agency of the United States Government. Neither the United States Government nor any agency thereof, nor any of their employees, makes any warranty, express or implied, or assumes any legal liability or responsibility for the accuracy, completeness, or usefulness of any information, apparatus, product, or process disclosed, or represents that its use would not infringe privately owned rights. Reference herein to any specific commercial product, process, or service by trade name, trademark, manufacturer, or otherwise does not necessarily constitute or imply its endorsement, recommendation, or favoring by the United States Government or any agency thereof. The views and opinions of authors expressed herein do not necessarily state or reflect those of the United States Government or any agency thereof.
\end{abstract}

This report has been reproduced directly from the best available copy.

Available from the National Technical Information Service, U. S. Department of Commerce, Springfield, Virginia 22161.

Price: Printed Copy A11

Microfiche A01

Codes are used for pricing all publications. The code is determined by the number of pages in the publication. Information pertaining to the pricing codes can be found in the current issues of the following publications, which are generally available in most libraries: Energy Research Abstracts (ERA); Government Reports Announcements and Index (GRA and I); Scientific and Technical Abstract Reports (STAR); and publication NTIS-PR-360 available from NTIS at the above address. 
DOE/MC/19285-1505, Vol. I

(DE84012005)

Distribution Category UC-90i

UC.90j

\title{
ANALYSIS OF POTENTIAL COMBUSTION SOURCE IMPACTS ON ACID DEPOSITION USING AN INDEPENDENTLY DERIVED INVENTORY
}

\author{
Volume I
}

December 1983

Work Performed Under Contract No.: DE-AC21-82MC19285

\author{
For \\ U. S. Department of Energy \\ Office of Fossil Energy \\ Morgantown Energy Technology Center \\ P.O. Box 880 \\ Morgantown, West Virginia 26505
}

By

PEDCo Environmental, Inc. 11499 Chester Road Cincinnati, Ohio 45246 and Paul W. Spaite Co. 6315 Grand Vista Drive Cincinnati, Ohio 45213 


\section{THIS PAGE \\ WAS INTENTIONALLY \\ LEFT BLANK}




\section{ACKNOWLEDGEMENT}

The Fuel Consumption and Emissions Data Base at Morgantown Energy Technology Center was generated as a part of the project. This fossil fuel combustion source inventory was developed by PEDCo Environmental, Inc., and the Paul W. Spaite Co. Thomas Lukow, Technical Project officer, METC, and Timothy Powers of EG\&G analyzed this. new data base, produced graphics, and performed quality assurance testing. Some of the results of these DOE efforts efforts are included in this report. In addition, Richard Harrington, DOE-FE, and William French, METC, provided important recommendations relating to the format and content of this two-volume report. 
THIS PAGE

\section{WAS INTENTIONALLY LEFT BLANK}


TABLE OF CONTENTS

$\underline{\text { Page }}$

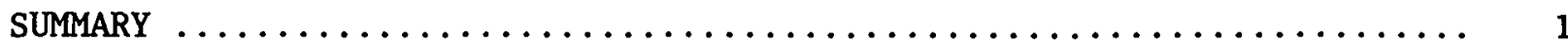

1. Introduction $\ldots \ldots \ldots \ldots \ldots \ldots \ldots \ldots \ldots \ldots \ldots \ldots \ldots \ldots \ldots \ldots$

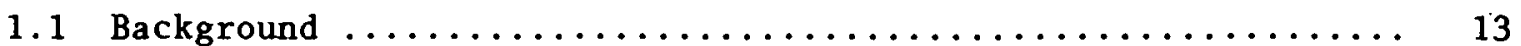

1.1 .1 Combustion Source Inventory ................. 13

1.1 .2 Analysis of Wet Deposition Data ............... 14

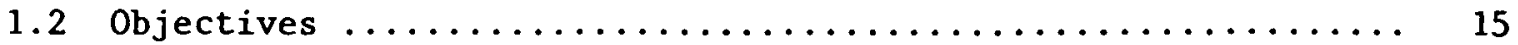

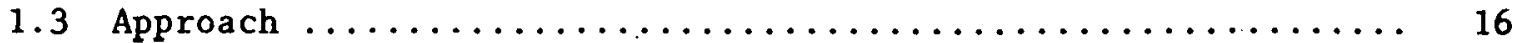

1.4 Report Content .............................. 19

2. Combustion Source Inventory and Acid Deposition Data

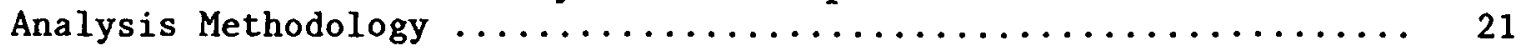

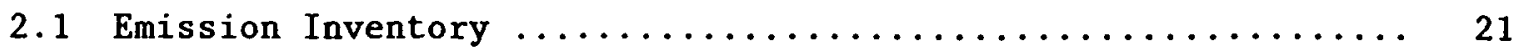

2.1.1 General Approach ....................... 21

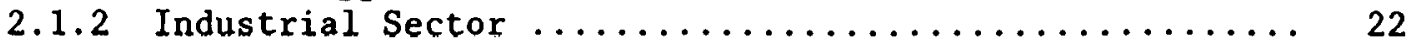

2.1 .3 Utility Sector ......................... 42

2.1 .4 Residential/Commercial Sector ................ 47

2.1.5 Transportation Sector ..................... 48

2.1.6 Summary Description of Data Base Installed

on DOE-METC Computer ................... 52

2.2 Methodology for Selection of Wet Deposition Monitoring Stations and Data Analysis Techniques ............ 54

2.2.1 General Approach -- Selection of Study Areas ........ 54

2.2.2 Evaluation of Existing Wet Deposition Networks for Analysis ..................... 55

2.2.3 Summary of Data Analysis Methods Applied to

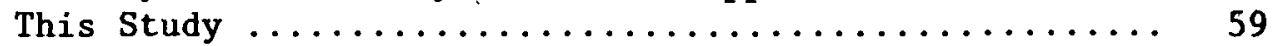

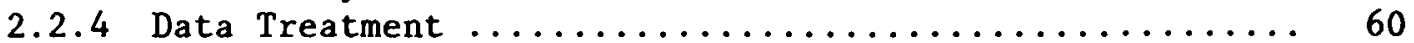

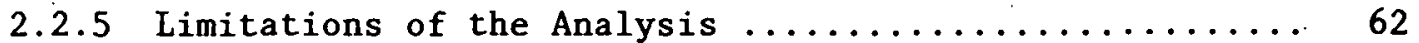

2.2 .6 Strengths of the Analysis .................. 64

3. Discussion of Inventory Resulıs ..................... 69

3.1 Discussion of $\mathrm{NO}_{\mathrm{x}}$, $\mathrm{SO}_{\mathrm{x}}$, and IIC Emissions $\ldots \ldots \ldots \ldots \ldots \ldots$

3.1 .1 Sector Summary Discussion $\ldots \ldots \ldots \ldots \ldots \ldots \ldots \ldots \ldots \ldots$

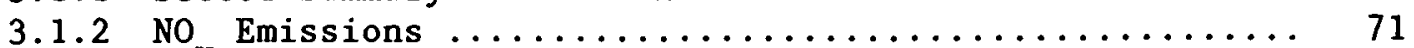

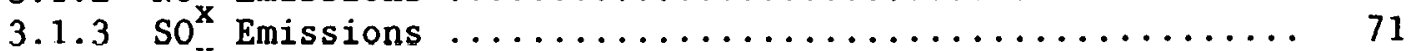

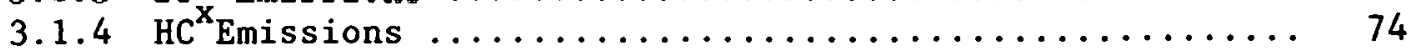


TABLE OF CONTENTS

(Continued)

Page

3.2 Sector Emission Summaries $\ldots \ldots \ldots \ldots \ldots \ldots \ldots \ldots \ldots \ldots \ldots \ldots \ldots$

3.2.1 Commercial/Residential Sectors $\ldots \ldots \ldots \ldots \ldots \ldots \ldots \ldots \ldots$

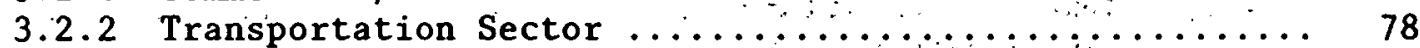

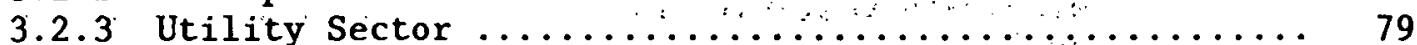

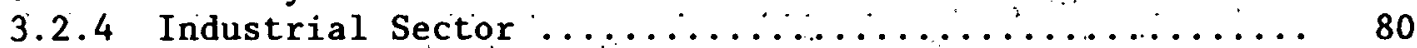

3.3 Emission Patterns $, \ldots \ldots \ldots \ldots \ldots \ldots \ldots \ldots \ldots \ldots \ldots \ldots \ldots \ldots \ldots \ldots \ldots, 86$

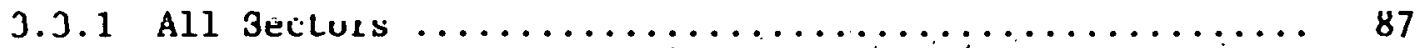

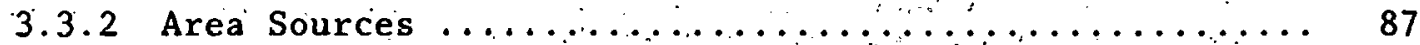

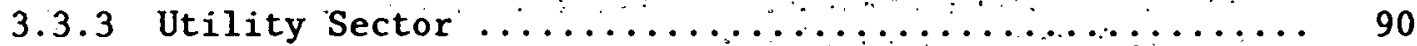

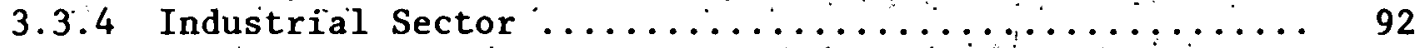

3.3.5 Emission Patterns in the Three Areas Chosen

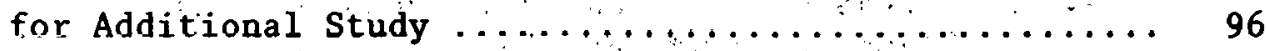

3.4 Comparison of National, Eastern U.S,, and Study

Area Fuel Consumption ......................... 108

3.5 Comparison of Study Area Emissions Versus NEDS $\ldots \ldots \ldots \ldots \ldots \ldots 11$

3.5.1 Transportation Sector ....................... 111

3.5.2 Residential/Commercial .................. 113

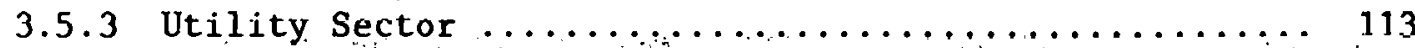

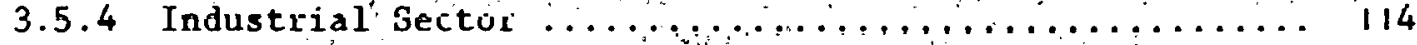

3.6 Comparison of Study Area Emissions Versus Work

Group 3B and the National Acid Precipitation

Assessment Program ........................... 115

4. Analysis of Possible Source Impacts $\ldots \ldots \ldots \ldots \ldots \ldots \ldots \ldots \ldots \ldots \ldots \ldots \ldots$

4.1 Introduction $\ldots \ldots \ldots \ldots \ldots \ldots \ldots \ldots \ldots \ldots \ldots \ldots \ldots \ldots \ldots \ldots \ldots \ldots$

4.1.1 Logic Behind Interpretation of Results ............. 118

4.1 .2 Staristical Procedures Used ...................... 119

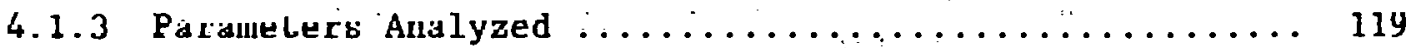

4.2 New York Area -- Hudson River Valley $\ldots \ldots \ldots \ldots \ldots \ldots \ldots \ldots \ldots \ldots \ldots$

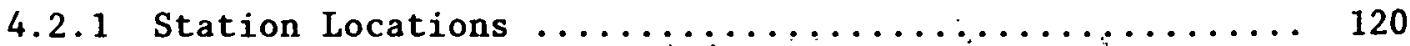

4.2 .2 Physical Features of the study Area ............... 120

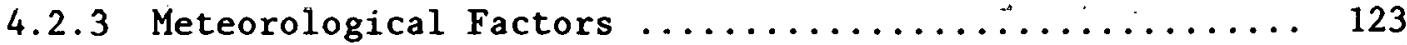

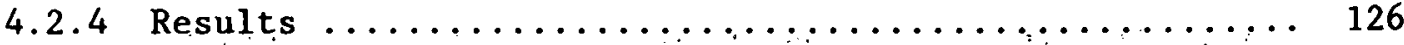

4.2 .5 Discussion of New York Results ................ 133 
TABLE OF CONTENTS

(Continued)

$\underline{\text { Page }}$

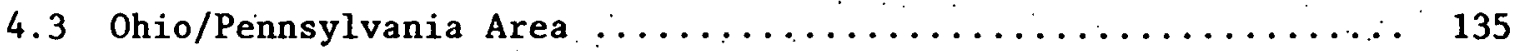

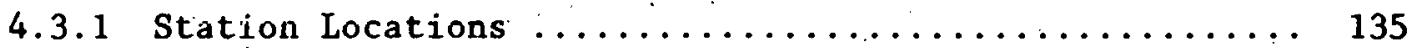

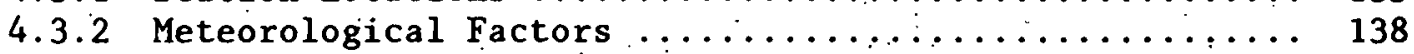

4.3 .3 Results ............................. 140

4.3.4 Discussion of Ohio/Pennsylvania Results ........... 150

4.4 Tennessee/South Carolina/North Carolina Area ............ 151

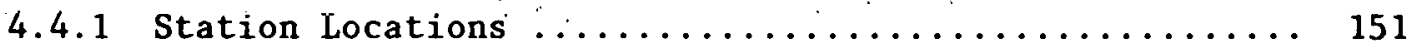

4.4.2 Physical Features of the Study Area ............. 151

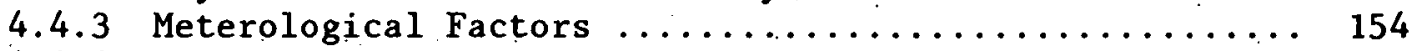

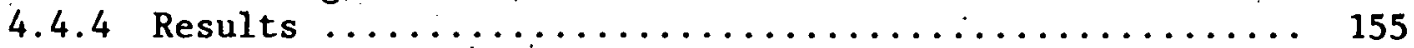

4.4.5 Discussion of Tennessee/South Carolina/

North Carolina Results ................... 164

4.5 Comparison of Study Results and Conclusions ............. 164

5. Conclusions and Recommendations $\ldots \ldots \ldots \ldots \ldots \ldots \ldots \ldots \ldots \ldots \ldots$

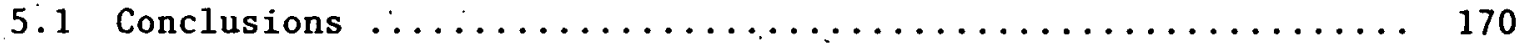

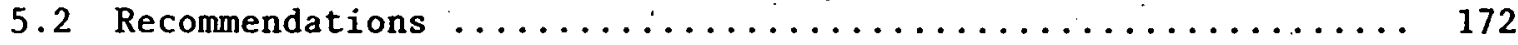

Appendix A Background Information for the Acid Deposition

Data.Analysis and Presentation of Detailed

Results for Each Study Area ..................... 175

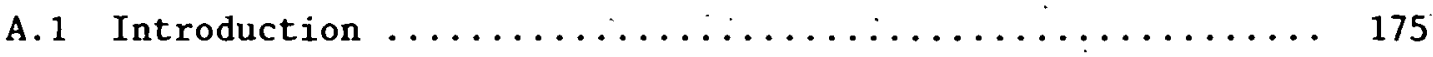

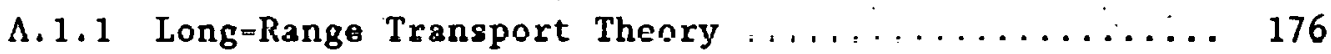

A.1.2 Focus of This Study .................... 177

A.2 Factors Influencing Wet Deposition ............. 179

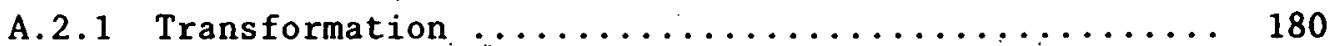

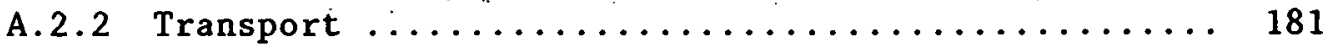

A.2.3 Deposition .......................... 184

A.3 Sclection of Data Analysis Methods $\ldots \ldots \ldots \ldots \ldots \ldots \ldots$

A.3.1 Time-Series Correlations ................. 186

A.3.2 Spatial Correlations .................. 188

A.4 Presentation of Wet Deposition Analysis Results ........ 189 


\section{LIST OF FIGURES}

Figure

$\underline{\text { Page }}$

1-1 Illustration of the 26-State Study Area East of the

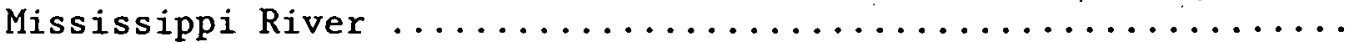

2-1 Graph for Estimating NO Emissions from Oil-Fired

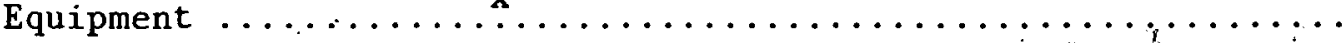

2-2 Graph for Estimating NO Emissions from Gas-Fired

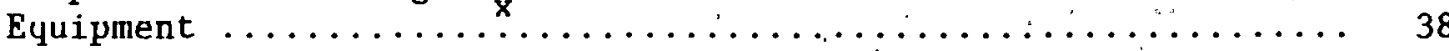

2-3 Sample Data Sheet from Pechan Data Base ..............

2-4 Locations of Sampling Sites Within Four Program Networks ..... 57

3-1 State Combustion Emission Densities for All Sectors in the Eastern United States ...................... 88

3-2 State Combustion Emission Densities for the Transportation, Commercial/Residental Sectors in the Eastern

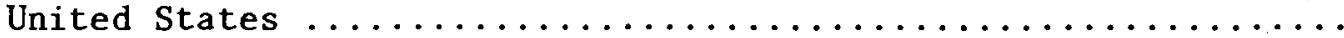

3-3 State Combustion Emission Densities for the Utility

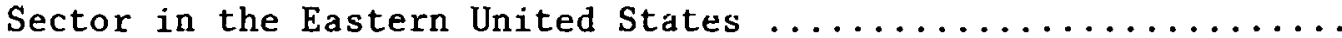

3-4 State Combustion Emission Densities for the Industrial

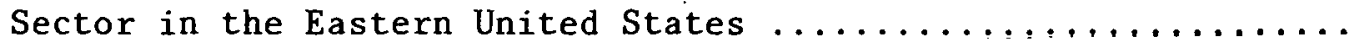

3-5 Distribution of Major Direct-Fired Facility Types

from Indiana through Pennsylvania .................... 94

3-6 Emission Density Ranges of NO for All Sectors Combined

in the New York-Hudson River Valley Study Area ............. 101

3-7 Emission Density Kanges of SO for Ail Sectors Combined

in the New York-Hudgon River Valley fitury Avet ............ 102

3-8 Emission Density Ranges of No by County for All

Sectors Combined in the Ohio/Pennsylvania Study Area .......... 104

3-9 Emission Density Ranges of SO by County for All

Sectors Combined in the Ohio/Pennsylvania Study Area .......... 105

3-10 Emission Density Ranges of NO for All Sectors

Combined in the Tennessee/South Carolina/North

Carolina Study Area ........................... 106

3-11 Emission Density Ranges of So for All Sectors Combined in the Tennessee/South Carolina/North Carolina Study Area ..... 107 
LIST OF FIGURES

(Continued)

Figure

Page

4-1 Location of Monitoring Stations in the New York Study

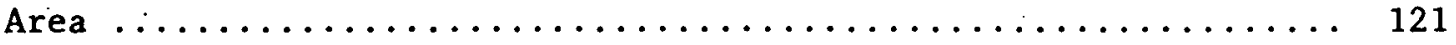

4-2 Winter, Spring, Summer, and Autumn Average Prevailing

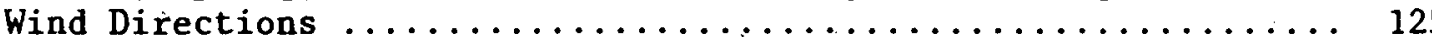

4-3 Emission Density Ranges of SO for All Sectors Combined in the New York-Hudson River Valley Study Area ............ 127

4-4 Emission Density Ranges of NO for All Sectors Combined

in the New York-Hudson River Valley Study Area ............ 128

4-5 Locations of Deposition Monitoring Stations in the Ohio/

Pennsylvania Study Area, and Separation Distances in

Kilometers ............................. 136

4-6 Prevailing Wind Directions in the Ohio/Pennsylvania

Study Area for January, April, July, and October ............ 139

4-7 Emission Density Ranges of So by County for All

Sectors Combined in the Ohio/Pennsylvania Study Area ......... 147

4-8 Emission Density Ranges of NO by County for All

Sectors Combined in the Ohio/Pennsylvania Study Area ......... 149

4-9 Tennessee/South Carolina/North Carolina Study Area, Sta-

tion Locations, and Separation Distances in Kilometers ........ 152

4-10 Prevailing Wind Directions, in the Mountain-Piedmont

Study Area for January, April, July, and October .......... 156

4-11 Emission Density Ranges of $\mathrm{SO}_{\mathrm{x}}$ for All Sectors Combined in the Tennessee/South Carolina/North Carolina Study Area ..... 161

4-12 Emission Density Ranges of NO for All Sectors Combined in the Tennessee/South Carolina/North Carolina Study Area ..... 163

LIST OF TABLES

$\underline{\text { Table }}$

$\underline{\text { Page }}$

2-1 List of Major Direct-Fired Combustion Point Source Processes and Associated $\mathrm{NO}_{\mathrm{x}}, \mathrm{SO}_{\mathrm{x}}$, and $\mathrm{HC}$ Emission Factors ......... 
LIST OF TABLES

(Continued)

Table

$\underline{\text { Page }}$

2-2 Large Industrial Boiler Emission Factors $\ldots \ldots \ldots \ldots \ldots \ldots \ldots \ldots \ldots$

2-3 Industrial Area Source Emission Factors $\ldots \ldots \ldots \ldots \ldots \ldots \ldots \ldots \ldots$

2-4 Utility Plant Emission Factors $\ldots \ldots \ldots \ldots \ldots \ldots \ldots \ldots \ldots \ldots \ldots$

2-5 List of Utility FGD Units East of the Mississippi

River Starting Operation After $1980 \ldots \ldots \ldots \ldots \ldots \ldots \ldots \ldots \ldots$

2-6 Residential and Commercial Emission Factors ............. 48

2-7 Trancportation Fuel Uses and Percentage of l'otal

Fossil Fuels .............................. 50

2-8 Summary of the Data Base by Sector for 26 States

East of the Mississippi ....................... 52

2-9 Industrial Direct-Fired Records for 26 States

East of the Mississippi ....................... 53

2-10 Acid Deposition Stations East of the Mississippi River ...... 56

2-11 Summary of Concurrent Weekly Observations Available in

Each Study Area $\ldots \ldots \ldots \ldots \ldots \ldots \ldots \ldots \ldots \ldots \ldots \ldots \ldots \ldots \ldots$

3-1 Annual Fuel Consumption and $\mathrm{NO}_{\mathrm{x}}, \mathrm{SO}_{\mathrm{x}}$, and $\mathrm{HC}$ Emissions

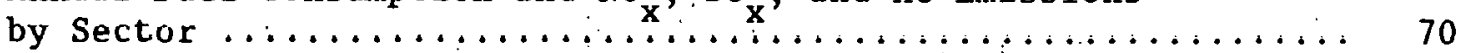

3-2. Summary of NO Emissions by Sector, State, and as

Percentage of Total Study Area $\mathrm{NO}_{\mathrm{x}}$ Emissions ............. 72

3-3 Summary of So Emissions by Sector; State, and as.

Percentage of $\mathrm{x}_{\mathrm{x}} \mathrm{Total}$ Study Area $\mathrm{SO}_{\mathrm{x}}$ Emissions $\ldots \ldots \ldots \ldots \ldots \ldots \ldots$

3-4 Summary of HC Emissions by Sector, State, and as

Percentage of Total Study Area HC Emissions .............. 75

3-5 First and Second Highest Emission Density Counties

for Each Sector in the Eastern United States .............. 77

3-6 Summary by State of Large Industrial Boiler Fuel Use and $\mathrm{NO}_{x}$, $\mathrm{SO}_{x}$, and $\mathrm{HC}$ Emiesions for Counties East of

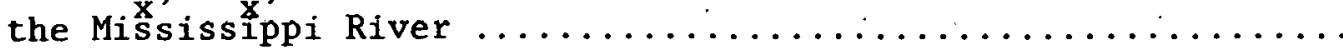

3-7 Summary of Fuel Consumption and $\mathrm{NO}_{x}$, SO ${ }_{x}$ and HC Emissions for Direct-Fired Point Sourcé Faclitities in the

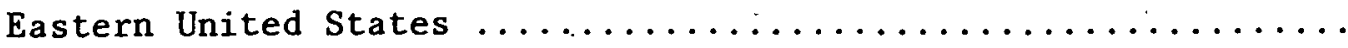


LIST OF TABLES

(Continued)

Table

$\underline{\text { Page }}$

3-8 Summary of County NO and SO Emission Densities by

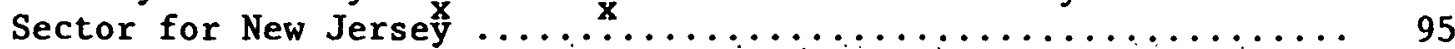

3-9 Total Emissions by Region for All Counties with More

Than 100 tóns $/ \mathrm{mi}^{2}$ per year for $\mathrm{NO}_{\mathbf{x}}$ or $\mathrm{SO}_{\mathbf{x}} \ldots \ldots \ldots \ldots \ldots \ldots \ldots \ldots \ldots$

3-10 Regional Densities for All Poilutants and All Sectors $\ldots \ldots . . .98$

3-11. Fuel Consumption Estimates by Fuel Types for the Study

Area and United States .......................... 10 g $^{\vdots}$

3-12 Fuel Consumption Estimates by Sector for the Study

Area and United States ......................... 109

3-13 Comparison of Combustion and Noncombustion Emissions ........ 110

3-14 Comparison of $\mathrm{NO}_{x}$, $\mathrm{SO}_{x}$, and HC Emission Estimates with

NEDS Emissions in the $26-$ State Study Area $\ldots \ldots \ldots \ldots \ldots \ldots \ldots \ldots \ldots \ldots$

3-15 Comparison of SO and NO Emissions from Canadian Work

Group 3B, National Acid Precipitation Assessment Program;

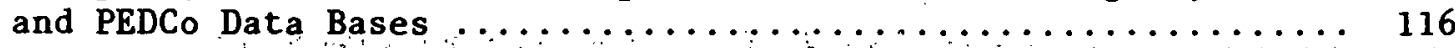

4-1 Acid Deposition Stations in the Hudson River Valley Area $\ldots \ldots \ldots 122$

4-2 Percent Winds from SSE-S-SSW at the Surface and $900 \mathrm{mb}$ at J.F.K. International Airport, New York ............... 126

4-3 Number of Concurrent Weekly Data Points $\ldots \ldots \ldots \ldots \ldots \ldots \ldots \ldots \ldots$

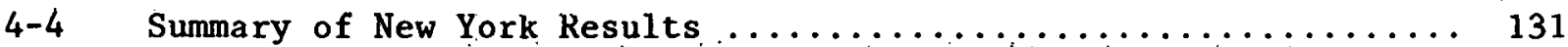

4-5 NADP Stations in the Ohio/Pennsylvania study Area $\ldots \ldots \ldots \ldots$

4-6. Number of Concurrent Weekly Data Points Availabiê in

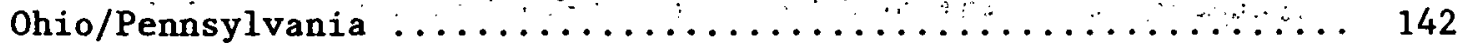

4-7 Deposition Rates at NADP stations in Ohio/Pennsylvania $\ldots \ldots \ldots \ldots 143$

4-8 Summary of Ohio/Pennsylvania Results $\ldots \ldots \ldots \ldots \ldots \ldots \ldots \ldots \ldots \ldots$

4-9 Acid Deposition Stations in the Tennessee/South Carolina/

4-10 Number of Concurrent Weekly Data Points Available at

Four Sites in Teinessee/South Carolina/North Carolina ......... 158

4-11 Summary of Tennessee/South Carolina/North Carolina Results .... 159 


\section{LIST OF TABLES}

(Continued)

Table

$\underline{\text { Page }}$

4-12 Summary of Sulfate Results for All Study Areas ............ 166

4-13 Summary of Nitrate Results for All Study Areas ............ 167 


\section{SUMMARY}

\section{REPORT OBJECTIVES}

This project had three major objectives. The first objective was to develop a fossil fuel combustion source inventory ( $\mathrm{NO}_{\mathrm{x}}, \mathrm{SO}_{\mathrm{x}}$, and hydrocarbon emissions) that would be relatively easy to use and update for analyzing the impact of combustion emissions on acid deposition in the eastern United States. The inventory should also be useful for energy-related studies. This inventory could be used as 1) an alternative to the EPA National Emission Data System (NEDS) data base (inasmuch as NEDS will require considerable modification before it can be used for modeling acid rain precursor impacts), or 2) an independent source for checking modifications that have been made to the EPA-NEDS data base.

The eecond objective of the project was to use the inventory data as a basis for selection of a number of areas that, by virtue of their importance in the acid rain issue, could be further studied to assess the impact of local and intraregional combustion sources.

The third objective was to conduct an analysis of wet deposition monitoring data in the areas under study, along with pertinent physical characteristics, meteorological conditions, and emission patterns of these areas, to investigate probable 
relationships between local and intraregional combustion sources and the deposition of acidic material. Statistical techniques such as intersite correlations and analysis of variance of deposition means were to be used as a means of measuring variations in acid deposition as a function of season, wind direction, and location of emission sources.

METHODOLOGY FOR DEVELOPING THE COMBUSTION SOIRCE INVENTORY

The combustion inventory covers all sectors: residential, commerclal, transportation, utility, and industrial. The basis of the inventory is primarily the total fuel used in each sector (with the exception of the utility sector, which is based on reported fuel-use data). Point sources were defined as those having fuel consumption $\geq 100 \times 10^{9} \mathrm{Btu} / \mathrm{Yr}$, and area sources were assumed to consume $<100 \times 10^{9} \mathrm{Btu} / \mathrm{yr}$.

The techniques used to develop the invontory consisted of a combination of new approaches, data from the open literature, and some data from NEDS (industrial boilers). For example, the approach to the evaluation of the direct-fired industrial sources to be included in the inventory was to use the Standard Industrial Classification (SIC) industry codes and the $100 \times 10^{9}$ Btu/yr reference value to evaluate 150 sic codes.: A list of 16 industries containing 45 facility types was produced.

For utilities, a specific listing of energy usage and emission estimates for the $800+$ utility plants in the eastern United States was selected as the principal data base because it combined information from a number of commonly used and acceptable 
information sources. For area sources, state fuel totals from U.S. Department of Energy publications were distributed to counties on the basis of population, vehicle registrations, or manufacturing establishments, depending on the sector being addressed.

The resulting data base, which has been installed on the Department of Energy's computer at METC, consists of a file of 8310 records, each pertaining to one of the seven sectors in the study: transportation, commercial, residential, utility, industrial boiler, industrial direct-fired, and industrial area. A single record exists for each of the 1576 counties in the study area for the transportation, commercial, residential, and industrial area sectors.

Each record contains identifiers for the state, county, and sector. Each also contains annual fuel consumption and the amount of $\mathrm{NO}_{x^{\prime}}, \mathrm{SO}_{\mathrm{x}}$, and $\mathrm{HC}$ (in tons) associated with each fuel. Records for point sources (utilities, industrial boilers, and industrial direct-fired sources) contain a facility identification number and the facility name. Records for industrial direct-fired plants also contain annual production (in tons).

\section{AREAS IDENTIFIED FOR ADDITIONAL ANALYSIS}

A review of the combustion source fuel and emission data as it was being generated led to the selection of three areas for further analysis: 1) the New York metropolitan area and northward through the Hudson River Valley to the Adirondacks (which has been extensively studied in the past), 2) eastern Ohio, upwind of the highly industrialized Pittsburgh area (the area most 
often defined as the probable major contributor to acid deposition in the Northeast, and 3) the Tennessee/North Carolina border area (scattered areas of low-, medium-, and high-emission densities that are not believed to be subject to significant long-range transport). Later examination of more detailed emissions data confirmed that these three locations were appropriate for further analysis.

METHODOLOGY FOR CHOOSING AN ACID DEPOSITION NETWORK AND SITES

In an evaluation of various operating acid deposition data bases in the Eastern United States, parameters such as representative siting, data availability, sampling technology, and quality assurance procedures were compared. Based on this evaluation, data generated by four acid deposition monitoring networks were gathered and tabulated for subsequent analysis.

Only wet deposition data from the National Atmospheric Deposition Program (NADP) network were used. Although ary deposition data are also available, the completely different deposition functions of wet and dry deposition create great uncertainty regarding the adequacy of dry deposition measurement techniques.

\section{INVENTORY ANALYSIS RESULTS}

The discussion of the inventury rcsults covers 1) analysis of the importance of $\mathrm{NO}_{x}, \mathrm{SO}_{\mathbf{x}}$, and $\mathrm{HC}$ emissions by sector; 2 ) analysis of emission patterns in each of the three study areas; and 3) comparison of the inventory fuel. and emission estimates with data from other independent sources. 
As expected, the $\mathrm{NO}_{\mathrm{x}}$ and $\mathrm{sO}_{\mathrm{x}}$ emissions $\left(32.2 \times 10^{6}\right.$ tons/yr) were much more dominant than HC emissions (only $3.6 \times 10^{6}$ tons/ yr). In some densely populated areas with high motor vehicle usage, however, the HC emission densities can be quite high. The contributions of the sectors to the total $\mathrm{NO}_{\mathrm{x}}$ emissions of $11.5 \mathrm{x}$ $10^{6}$ tons/yr were as follows: 42 percent from transportation, 33 percent from utilities, and 20 percent from industrial sources. The major sector contributions to the so $x$ total of $20.8 \times 10^{6}$ tons/yr were 72 percent from utilities and 24 percent from industrial sources (which represented the vast majority of the so $_{x}$ emissions).

An examination of the data on each sector pointed up the following :

- Although emissions in the commercial/residential sector are low, the sources of combustion emissions in this sector can be important where population densities are high.

- Emission density levels in the transportation sector were substantial and actually dominated the emissions in some areas. Although fuel use was distributed by motor vehicle registration, emissions in the transportation sector tended to reflect population density (similar to residential/commercial patterns).

- The utilities are dominant generators of $\mathrm{NO}_{\mathrm{x}}$ and $\mathrm{SO}_{\mathrm{x}}$ in most counties where they are located. The study are has a total of 779 utility plants, which were located in all states except Vermont.

- Fuel use and emissions in the industrial sector were dominated by the area source component, which accounted for 63 persent of the energy consumption and 72 percent of total emissions. This occurred because a large percentage of the industrial fuel consumption was not accounted for by the large industrial boilers ( $>250$ $\left.x 10^{6} \mathrm{Btu} / \mathrm{h}\right)$ and direct-fired point sources that were identified in the study area. Overall, boilers $>250 \mathrm{x}$ $10 \mathrm{Btu} / \mathrm{h}$ accounted for an estimated 30 percent of the 
industrial boiler fuel, and point sources $>100 \times 10^{9}$ Btu/yr accounted for 43 percent of the direct-fired fuel.

For direct-fired point sources, the top 15 energy-consuming facility types accounted for 97 percent of both the direct-fired energy consumption and the total emissions of $\mathrm{NO}_{\mathbf{x}^{\prime}} \mathrm{SO}_{\mathbf{x}}$, and $\mathrm{HC}$. The remaining 20 facility types accounted for only 3 percent of the energy and total direct-fired combustion emissions. This indicated that the $100 \times 10^{9} \mathrm{Btu} / \mathrm{yr}$ plant cutoff value established to classify direct-fired plants as point sources included all major direct-fired processes.

A marked geographical concentration of large industrial boiler facilities was noted. Nearly one-half of the total fuel consumption occurs in five states: Indiana, Florida, Ohio, New York, and Alabama. This concentration is even more striking at the county level. About one-quarter of the total industrial boilex fuel consumption can be accounted for by 10 counties. The majority of the large boiler facilities werc in the pulp and paper, chemicals, iron and steel, and petroleum industries. The remainder were in a variety of other industrial categories, including miscellaneous manufacturing, food products, and textiles.

\section{COMPARISON OF EMISSION PATTERNS IN THE THREE STUDY AREAS}

A comparison of emission densities at the county level in all three study areas indicated that very small areas (such as. New York County, New York) can produce very high.emission. densities although emissions are modest. This points up the weakness of using emission densities; however, this approach was still 
very useful in defining discrete emission concentrations and emission patterns and was better than using total emissions.

It was also noted that focusing only on the high-emissiondensity counties will identify the majority of utility emissions, but it will neglect the majority of industrial emissions, which tend to be concentrated more in the medium- and low-emissiondensity counties. Even with this bias, however, the New York study area is stili generally dominated by nonutility emissions. Both the Ohio/Pennsylvania and Tennessee/North Carolina areas, however, generally show the utility sector to be the dominant contributor to high-emission-density counties.

The Hudson River valley, which is downwind of a highemission-density area around New York City, New Jersey, and eastern Pennsylvania, is influenced by high area source emissions and strong seasonal patterns of surface wind directions. The NADP stations in the evaluation are generally north of the highdensity areas. Area sources are dominant overall, but utility and induetrial point snurces also make significant contributions to some counties. This observation is based on a review of both the high-emission-density counties (>100 tons/yr per $\mathrm{mi}^{2}$ ) and the low- and medium-emission-density counties 110 to 100 tons/yr per $\mathrm{mi}^{2}$ ).

In the Ohio/Pennsylvania area, several medium- to high-emission-density counties are located between the two NADP sites in eastern Ohio and the two NADP sites in western Pennsylvania. The high-emission-density counties in ohio tend to be dominated by 
utilities, especially with regard to so $_{\mathbf{x}}$ emissions, but area and industrial sources can make significant contributions to emission densities, especially in counties with medium-emission densities. This is also true for high-emission-density counties in western Pennsylvania and northern West Virginia, except for Allegheny County, Pennsylvania, and Hancock County, West Virginia, where.. all sectors contribute to the high-emission density:

Emissions in the Tennessee/North Carolina border area are generally low, with pockets of high emissinns scattered throughout the area. Utilities are present in the majority of the highemission-density counties. Therefore, utility and, to a lesser extent, industrial point sources are the major contributors to the emission density in these pockets. Area sources have less. influence here than in the New York and Ohio/Pennsylvania areas. Two of the NADP stations are located within or very near pockets of high-emission density, and two are some distance from the highdensity area.

COMPARISON OF INVENTORY FUEL USE AND EMISSIONS WITH OTHER INDEPENDENT SOURCES OF DATA

$\lambda$ limited comparisuil of the tnventory fuel use and emissions was made with other independent data sources [primarily DOE's State Energy Data Base (SEDB) and EPA's NEDS]. Because a number of minor fuels in various sectors were not included in the inventory, the inventory accounted for 93.2 percent of the SEDB total, with the biggest discrepancy occurring in the "other fuels" portion of the industrial sector. 
A number of significant differences were noted in the inventory emission results when compared with NEDS totals for the same 26-state area, although a detailed investigation of the reasons for these differences was not within the scope of this project. The major difference occurred in the industrial sector where the inventory was much higher than NEDS. The main reason for this difference was the fact that coking coal emissions were double counted in the DOE inventory. An estimated correction factor applied to the industrial coal area source emissions resulted in the DOE and NEDS inventories being much closer for the 26 State study area. Other differences noted were 1) small combustion emission sources ( $<100$ tons/yr) are not included in the NEDS data base and 2j the combustion portion of NEDS process emissions are not separated from the actual process emissions. The impact of these differences in methodology in comparing the DOE and NEDS inventories, however, is not known.

Other differences were noted in the transportation sector (the inventory was lower than NEDS, which was believed to be due to the differences in the methodology of calculating emissions), and the residential and commercial sectors (possibly due to coal not being included in the inventory, although this was not guantified for the 26-state study area). These differences in emission estimates will be investigated further in future studies.

\section{DISCUSSION OF MONITORING DATA ANALYSIS RESULTS}

The results of the statistical analysis of monitoring data were used, along with emission patterns, the physical characteristics of the area, and important meteorological parameters in 
various seasons of the year, to draw conclusions regarding the : mechanisms influencing wet deposition at the monitoring stations.. in each of the three study areas.

Two statistical techniques were used: 1) intersite correlations (i.e., do the sites increase and decrease together?); and ... 2) ANOVA-analysis of variance (i.e., are the measured values at one site significantly different from the measured values at other stations in each study area?).

If pairs of stations showed high intersite correlations or similar ANOVA values, it was concluded (in conjunction with the other supporting information) that the stations were impacted by the same well-mixed air mass, and indicated that the same set for possibly a different set) of sources was impacting the stations. Low intersite correlations or significantly different ANOVA values indicated that the stations were being impactcd by different air masses and consequently, different (possibly more localized sources.

In conjunction with lilis analysis, the emission density patterns in each area were examined in relationship to thoir intonsity and their proximity to the monitoring stations. The physieal fuaturee of each area were characterized to determine how the geography of the area influenced the transport of the pollutants. Finally, a number of important meteorological parameters were evaluated for each area: 1) wind patterns by season, 2) precipitation patterns by season, and 3) the mixing of pollutants in the atmosphere. 
A review of the results of the analysis in all three areas indicated that the conclusions drawn from each area were consistent based on what is known about the physical location of stations in each area, the emission patterns surrounding the stations, and meteorological conditions in each area. A comparison of the results of the sulfate analysis in each area led to the following conclusions :

1) The New York-Hudson River Valley area shows localized impacts. Sulfate deposition at Essex County in the Adirondacks is contributed at least partially by emissions from the New York City/New Jersey area in that its deposition rate increases with that of the two stations close to New York City. These two southern stations are impacted in essentially the same manner from the New York City/New Jersey area.

2) In the Ohio-Pennsylvania area, it was impossible to identify unique source areas that impact each station differently because all four stations have essentially the same deposition values, which increase and decrease together by season. This is not unexpected, given the similarities in climate, emission densities, and terrain at each station.

3) Localized impact was obvious in the Tennessee/North Carolina area in the comparison of several pairs of stations. The two stations most distant from emission sources generally do not correlate with those sites near to emission areas. One station situated near an area with high emission density clearly shows higher deposition rates when the wind is from the direction of this high-emission-density area. Results at those station pairs separated by physical divisions such as mountain ridges or distances greater than 150 miles generally do not correlate with one another, which indicates the tendency for deposition fairly close to high-emission-source areas.

A comparison of nitrate emissions from the three areas led to the following conclusions:

1) The impact of the New York/New Jersey metropolitan area is apparent when the deposition rates and correlations for one site near New York and the northern site in the Adirondacke are compared. The two sites near New York are not impacted in a similar manner as would be expected based on their proximity and the sulfate results. 
2) The Ohio/Pennsylvania nitrate results are the same as for sulfates. The results also confirm the greater winter nitrate deposition rates often discussed in the literature.

3) The two most highly industrialized areas in the Tennessee/North Carolina area produre significantly higher nitrate deposition rates than the most rural station, presumably because of the industrial/urban contribution.

OVERALL CONCLUSIONS

The main conclusions emerging from this report are as fol-

lows:

1) The combustion source emissions inventory that has been developed for the eastern United States adequately characterizes all important area sources and point sources on a county-by-county basis. Thio data base has been computerized and is to be complete without inclusion of unnecessary detail. Its design provides flexibility and simplicity and makes it uniquely useful in overall analysis of emission patterns in the eastern United States.

2) Three regions with basically different emission patterns have been identified and characterized. The statistical analysis of wet deposition monitoring data in conjunction with emission patterns, wind direction, and topography has produced consistent results for each study area and has demonstrated that the wet deposition in each area reflects the characteristics of the localized area around the monitoring sites (typlcally 50-150 miles). 
SECTION 1

INTRODUCTION

\subsection{BACKGROUND}

\subsubsection{Combustion Source Inventory}

Past attempts to evaluate the contribution of sources of acid rain precursor compounds (i.e., sulfur dioxide and nitrogen oxides) have pointed up the need for a better definition of the ways in which fossil fuels are burned. Many aspects of energy. supply and demand are already well documented. For example, data are available on the use of all major fuels in the various consuming sëctors (residential, commercial, industrial, utility, and transportation). Lack of information on the characteristics and location of the hardware consuming these fossil fuels, however, limits the analysis of fuel use and associated problems in two ways. First, fuel requirements cannot be defined with the specificity needed to make definitive estimates for possible fuel substitution. Second, process discharges cannot be defined with the specificity needed to evaluate the environmental consequences of the various forms of combustion.

A properly designed inventory of combustion sources could meet the informational needs for an analysis of fossil fuel usage. Currently, only one data base incorporates the kind of information required for a national inventory of combustion equipment. The National Emission Data System (NEDS), maintained 
by the Office of Air Quality Planning and Standards (OAQPS) of the U.S. Environmental Protection Agency (EPA), stores informa-. tion on combustion sources and other sources of air pollution. Although this system has served its purpose throughout the years since its inception in 1971, recent evaluations have shown it to be inadequate for current needs.*

Two options are available for development of an improved inventory: 1) to modify the combuetion souroe inventory inoorporated in NEDS; or 2) to devise a plan for development of an inventory independent of NEDS, one that does not rely solely on survey data (as NEDS does) and is designed to meet the specific requirements of the current analysis. Such an inventory should be complete as far as essential items are concerned and free of unnecessary detail that would limit its flexibility in analysis of fuel use patterns. Based on an analysis of these and other considerations (such as the need to evaluate sources of data that have not been widely used for inventory purposes), the second option was believed to be the better choice.

\subsubsection{Analysis of Wet Deposition Data}

Past attempts to determine the relative contributions of various sources of acid rain precursors to acid deposition (primarily in the northeastern United States) have focused on the use of long-range transport models and the general assumption that sources in the Midwest were primarily responsible for acid

* The EPA itself has concluded that NEDS will require considerable modification to meet their needs as a data base for the modeling of acid rain. 
deposition in the northeastern United States. Although Midwestern sources undoubtedly do contribute to acid deposition in the northeastern United States, the extent of this contribution has not been determined.

Currently available long-range transport models are not sufficiently developed for their reliable use as the basis of policy decisions regarding which sources should be controlled to reduce acid deposition in the northeastern United States. Thus, this study focuses on a simpler approach, i.e., the analysis of various wet deposition monitoring data in three eastern U.S. study areas as an alternative to the use of long range transport models. The results of these analyses are then combined with available information on the physical characteristics and meteorology (by season) in each study area and the combustion source emission patterns in areas surrounding wet deposition monitors to yield qualitative information about the potential contribution of combustion sources to acid deposition in the areas under study.

\subsection{OBJECTIVES}

The specific objectives for this project were as follows:

1) To develop a combustion source inventory, independent of fuel survcy data obtained from users, for use in the assessment of fuel use and the resulting environmental impacts, particularly acid rain. Such an inventory should account for the burning of all fossil fuels and provide the information needed to estimate nitrogen oxides ( $\left.\mathrm{NO}_{\mathrm{x}}\right)$, sulfur oxides $\left(\mathrm{SO}_{\mathrm{x}}\right)$, and hydrocarbon (HC) emissiofs from all sources of a countyby-county basis. Hydrocarbon emissions from combustion sources are included because of their role in the production of chemical oxidants. 
2) To use the inventory data (detailed to a county level for all consuming sectors) to identify the predominant areas of emissions generation and to assess their potential for contribution to regional acidification of precipitation.

3) To review acid rain monitoring data to determine availability of high-quality data for analysis; to use techniques to compare variations in seasonal values at stations in selected areas, and to use these results', along with meteorological information, to identify probable relationships between emission patterns and the deposition of acidic material.

\subsection{APPROACH}

The approach to inventory development was designed to provide an accounting of all reported fossil fuel combustion in the commercial, residential, industrial, utility, and transportation sectors. All fossil fuel combustion in these sectors was assigned to either major point sources* or area sources** for all counties in the 26 states (plus the District of Columbia) east of the Mississippi. This study area is shown in Figure 1-1.

For purposes of retaining the simplicity necessary for subsequent analysis, certain minor fuel uses were included with major uses; e.g., gasoline for motor boats is included with that for automobiles, and jet fuel burned by utilities was included with other distillate fuels. (The significant assumptions made in development of the inventory are discussed in Section 2.1.) This approach permitted analysis of all fuel consumption without

\footnotetext{
* Point sources for this study were defined as those facilities with fuel use $\geq 100 \times 10^{9} \mathrm{Btu} / \mathrm{yr}$.

** Area sources for this study were defined as those facilities with fuel use $<100 \times 10^{9} \mathrm{Btu} / \mathrm{yr}$.
} 


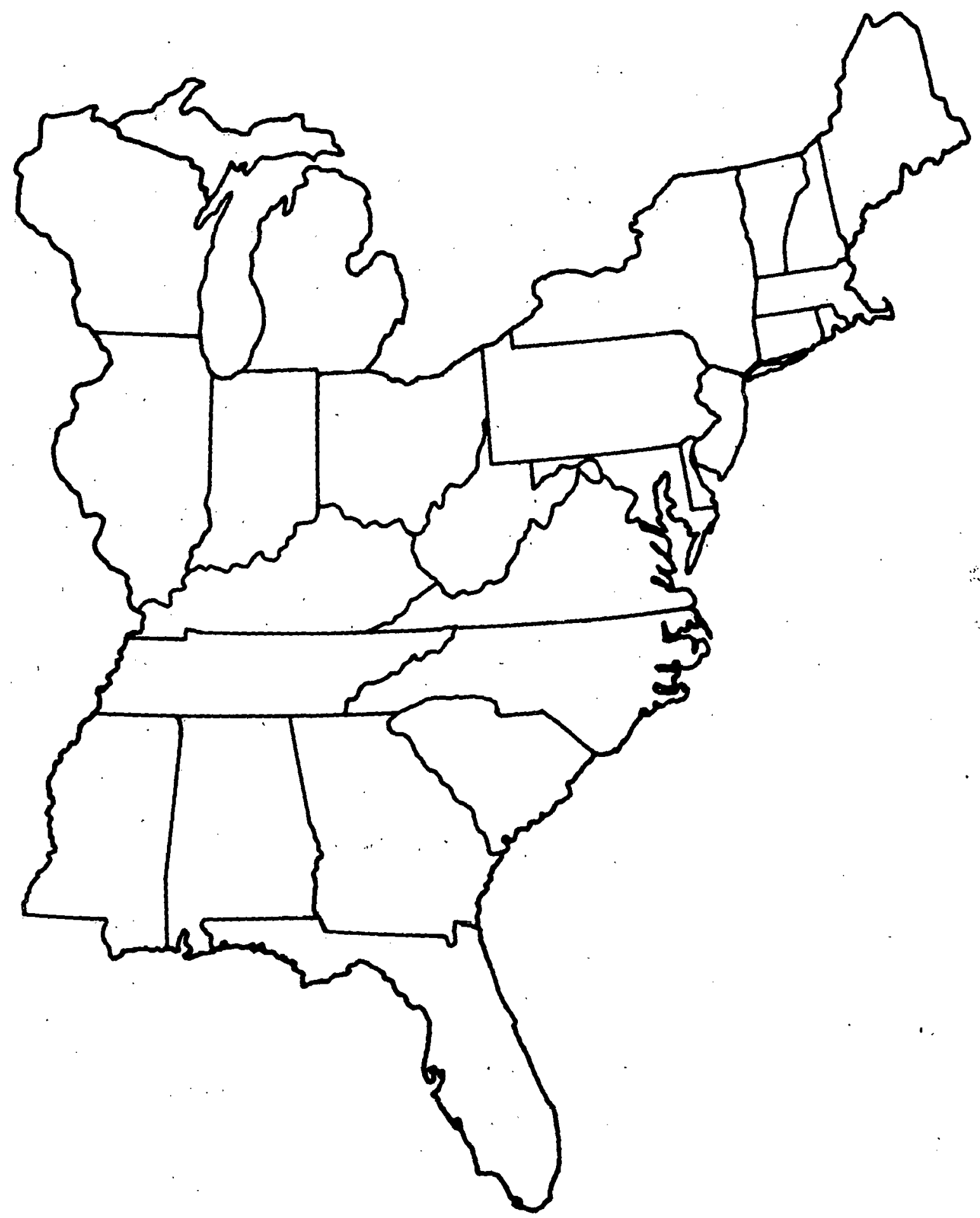

Figure 1-1. Illustration of the 26-state study area east of the Mississippi River. 
a proliferation of categories whose analysis would not significantly increase the accuracy of the inventory or the emission estimates.

For sectors other than industrial, the procedures for determination of fuel consumption for both point and area sources on a county-by-county basis were relatively straightforward. For the industrial sector, however, an approach was devised that used Census of Manufacturers data to identify all individual industrial processes that should be classified (on the basis of estimated annual fuel combustion) as "major point sources." The industrial fuel consumption other than that accounted for as fuel in major point sources was distributed as industrial area sources on a county-by-county basis.

After the source inventory was developed, fuel consumption estimates were used to develop emission estimates for $\mathrm{NO}_{\mathbf{x}} \mathrm{SO}_{\mathbf{x}}$ ! and HC for approximately 1600 counties in the study area. These counties were analyzed to identify areas with high emission density and to locate areas having the greatest potential for local and intraregional impacts on acid deposition.

Acid rain monitoring data in the eastern United States were reviewed and evaluated. For three areas showing emission patterns of interest, an analyeie wae pcrformed to determine the presence of any apparent associations between acidity of precipitation and emission patterns, wind direction, and season of the year. These three areas were 1) the New York Metropolitan Area and sites extending north through the Hudson River Valley (which 
has been extensively studied in the past); 21 sites in eastern Ohio that are upwind of the highly industrialized Pittsburgh area (the area most often indicated as the probable major contributor to acid deposition in the Northeast) and sites in western Pennsylvania that are downwind of this area; and 3) sites around the Tennessee/North Carolina border area (an area of low- to medium-emission densities that is not believed to be subject to significant long-range transport).

\subsection{REPORT CONTENT}

The information in this study is presented in two volumes. In Volume I, Section 2, the approach to this study is discussed as it pertains to the combustion source inventory, the selection of wet deposition monitoring stations, and data analysis techniques. Section 3 of this volume presents an analysis of the results of the source inventory and emission patterns, section 4 presents a review and analysis of acid rain monitoring data for the three study regions, and Section 5 states the conclusions and recommendations resulting from the study. Appendix A presents the background information used as the basis for conducting the analysis of wet deposition monitoring data and detailed information on the results of the statistical analysis of the wet deposition monitoring data in the three study areas.

Volume II consists of two appendices that arc related to the inventory portion of this study. Appendix A provides detailed documentation of the methodology used to calculate fuel 
use and emissions from direct-fired sources in the industrial sector. Appendix B summarizes an analysis of 4-digit industrial SIC codes that formed the basis of the direct-fired point source population used in the inventory. 


\section{SECTION 2}

COMBUSTION SOURCE INVENTORY AND ACID

DEPOSITION DATA ANALYSIS METHODOLOGY

This section summarizes the methodology used 1) to develop an independent combustion source energy and emissions ( $\mathrm{SO}_{\mathbf{x}}$ ' $\mathrm{NO}_{\mathbf{x}}$ ' and HC) inventory for 1600 counties in 26 states (plus the District of Columbia) east of the Mississippi River, and 2) to evaluate and choose wet deposition monitoring stations for an analysis of the variations in deposition rates in different seasons of the year.

\subsection{EMISSION INVENTORY}

\section{1 .1 General Approach}

After an examination was made of various approaches for developing an independent combustion source inventory, the utilization of data from the open literature was selected as the best method. Past work had demonstrated the feasibility of this approach and indicated that it could be designed to be compatible with data available from NEDS. The latter was desirable because it would permit making comparisons between the two systems if necessary. Paet work had also shown the feasibility of using an energy-accounting approach for overall analysis and had demonstrated that the industrial sector, which presented the most unknowns, was amenable to systematic analysis involving the 
use of Standard Industrial Classification (SIC) industry codes to provide a frame of reference. Hence, these techniques were used to develop the energy and emission data base. The approach for all sectors (i.e., industrial, utility, residential/commercial, and transportation) is described in further detail in the following subsections.

\subsubsection{Industrial Sector}

The three components of the industrial sector are directfired processes, industrial boilers, and industrial area sources. Following is a description of the methodology used to calculate fuel-based energy consumption and combustion emissions for each of these components.

Direct-Fired Sources--

Direct-fired industrial processes are defined as those that use fossil fuel to provide process heat. The combustion gases from the firing of fossil fuel can come into direct contact with the product (such as in a cement kiln), or they can be exhausted separately (such as in preheaters for atmospheric distillation units in refineries). Appendix $A$ in Volume II provides detailed documentation of the procedures used to estimate energy ard emissions for individual direct-fired processes burning solid, liquid, and gaseuus fuels. The romainder of this sertion deals with the general methodology used in developing the direct-fired source population evaluated in this study.

Previous work, in which Census of Manufacturers' data were used for four-digit SIC codes, formed the basis for the population of direct-fired sources evaluated here (see Appendix B in. 
Volume II). About 450 industries in SIC Codes 20 through 39 were investigated. Computation and inspection of energy consumption values showed that many of the 450 4-digit SIC categories included establishments with average annual energy consumption values of less than $100 \times 10^{9} \mathrm{Btu} / \mathrm{year}$. This is about equal to the fuel used by a 2- to 3-MW equivalent boiler operated 4000 to 5000 hours per year. Hence it was reasoned that establishments with average fuel consumption values below this limit could hardly be employing direct-fired processes of significant size, and further analysis was limited to 114 categories to determine whether their direct-fired fuel use exceeded this minimum.

This final analysis produced a list of 17 industries and 45 facility types, which is believed to be a comprehensive list of direct-fired industrial point sources. Of the 45 facility types identified, only 35 were located in the eastern United States study area, and these are the ones included in the inventory. The complete list of direct-fired sources is presented in Table 2-1, along with $\mathrm{NO}_{\mathrm{x}}, \mathrm{SO}_{\mathrm{x}}$, and HC emissions factors obtained for each process (which are discussed in a later section). The following subsection discusses the procedure used to reduce the possibility of missing major direct-fired sources. $\therefore$ Documentation of the direct-fired source listing--Various background references (many of which were industry specific) were compiled and used in developing and checking the population of direct-fired industrial sources. Eight primary references. and nine supplemental references comprised the cornerstone of 
TABLE 2-1. LIST OF MAJOR DIRECT-FIREQ COMBLSTION POINT SOURCE PFOCESSES AND ASSOCIATED NO ${ }_{x}$, $S O$, AND HC EMISSION FACTORS

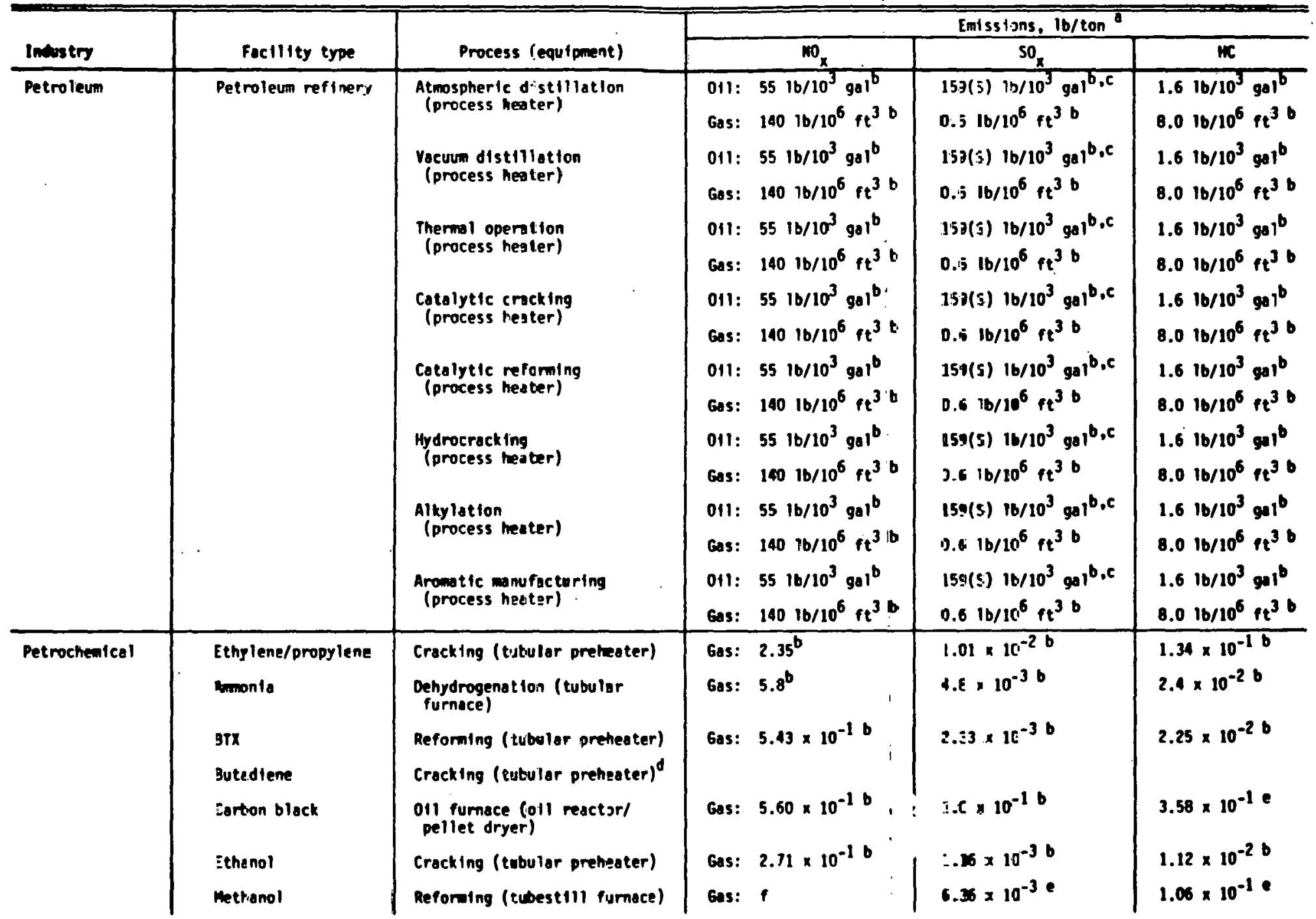

(continued) 
TABLE 2-1 (continued)

\begin{tabular}{|c|c|c|c|c|c|}
\hline \multirow[b]{2}{*}{ Industry } & \multirow[b]{2}{*}{ Facllity type } & \multirow[b]{2}{*}{ Process (equipment) } & \multicolumn{3}{|c|}{ Enissions, $16 /$ ton } \\
\hline & & & $\mathbf{m o x}_{\mathrm{x}}$ & & KC \\
\hline $\begin{array}{l}\text { Industrial organic } \\
\text { chentcals }\end{array}$ & $\begin{array}{l}\text { Oimethyl terephalate } \\
\text { Styrene }\end{array}$ & $\begin{array}{l}\text { Oxidation/esterification (tubu- } \\
\text { lar prehed ter } \\
\text { Alkylation/dehydrogenation } \\
\text { (superheater) }\end{array}$ & $\begin{array}{l}\text { Gas: } 4.92 \times 10^{-16} \\
\text { Gas: } 9.01 \times 10^{-16} b\end{array}$ & $\begin{array}{l}2.11 \times 10^{-36} \\
3.86 \times 10^{-3} 6\end{array}$ & $\begin{array}{l}2.04 \times 10^{-26} \\
3.73 \times 10^{-2} b\end{array}$ \\
\hline $\begin{array}{l}\text { Industrial inorgan- } \\
\text { tc chemicals }\end{array}$ & $\begin{array}{l}\text { Alumina } \\
\text { Borax } \\
\text { Lithtum carbonate } \\
\text { Sodlum carbonate } \\
\text { Titanium dioxide } \\
\text { sulfate }\end{array}$ & $\begin{array}{l}\text { Calcination (rotary ailn or } \\
\text { fluld bed calciner) } \\
\text { Orying (tray or spray dryer) } \\
\text { Colcination (rotary kiln) } \\
\text { Roasting (acid roaster) } \\
\text { Monohydrate (rotary } k i l n)^{d} \\
\text { Orying (slag dryer) } \\
\text { Colciner (rotary } k \mid l n \text { ) }\end{array}$ & $\begin{array}{l}\text { 011: } f \\
\text { Gas: } f \\
\text { Gas: } f \\
\text { Gas: } f \\
\text { 011: f } \\
\text { Gas: } f\end{array}$ & $\begin{array}{l}6.31 \times 10^{-1}(5)^{c, e} \\
1.35 \times 10^{-3} \mathrm{e} \\
9.60 \times 10^{-3} \mathrm{e} \\
6.64 \times 10^{-3} \mathrm{e} \\
4.17 \times 10^{-1}(5)^{c, e, g} \\
1.806 \times 10^{-2} \mathrm{e.g}\end{array}$ & $\begin{array}{l}1.66 \times 10^{-2} \mathrm{e} \\
2.24 \times 10^{-2} \mathrm{e} \\
1.60 \times 10^{-1} \mathrm{e} \\
1.11 \times 10^{-2} \\
7.56 \times 10^{-3} \mathrm{e.9} \\
3.01 \times 10^{-1} \mathrm{e.9}\end{array}$ \\
\hline $\begin{array}{l}\text { Phosphate rock and } \\
\text { basic fertilizer }\end{array}$ & Potosh & $\begin{array}{l}\text { Calcination (rotary kiln) } \\
\text { Drying (rotary dryer) } \\
\text { Leaching (rotary oryer) } \\
\text { Calcination (fuston furnace) } \\
\text { Calcination/drying (rotary } \\
\text { kiln/sproy dryer) }\end{array}$ & $\begin{array}{l}\text { Ges: } 2.38 \times 10^{-1} \mathrm{f} \\
\text { Ges: } 4.13 \times 10^{-1} \mathrm{f}\end{array}$ & $\begin{array}{l}2.95 \times 10^{-3} e \\
3.55 \times 10^{-3} \mathrm{e}\end{array}$ & $\begin{array}{l}4.92 \times 10^{-2} \bullet \\
5.91 \times 10^{-2} e\end{array}$ \\
\hline Pulp and paper & Krafe pulp & Line regeneration (1fine kiln) & $\begin{array}{l}\text { 0i1: } 3.0^{\circ} \\
\text { Gas: } \cdot 3.0^{b}\end{array}$ & $\begin{array}{l}4.60 \times 10^{-1}(s)^{b . h} \\
2.30(s)^{b .1} \\
2.35(s)^{b . J} \\
3.519 \times 10^{-3} e\end{array}$ & $\begin{array}{l}1.73 \times 10^{-16} \\
5.865 \times 10^{-2}=\end{array}$ \\
\hline Gypsum & Gypsum & $\begin{array}{l}\text { Drying/calcination (dryer/ } \\
\text { calciner) }\end{array}$ & Gas: $f$ & $3.08 \times 10^{-4} \mathrm{e}$ & $5.13 \times 10^{-36}$ \\
\hline Lime & Lime & Calcination (Iime kiln) & $\begin{array}{l}\text { Gas: } 1.79^{\mathrm{e}} \\
\text { Coal: } 3.0^{\mathrm{b}}\end{array}$ & $\begin{array}{l}3.00 \times 10^{-3} \mathrm{e} \\
6.10 \times 10^{-1}(s)^{b, c, 0} \\
3.04(s)^{b, c . p}\end{array}$ & $\begin{array}{l}5.80 \times 10^{-2} e \\
1.35 \times 10^{-1}\end{array}$ \\
\hline
\end{tabular}

(continued) 
TABLE 2-1 (continued)

\begin{tabular}{|c|c|c|c|c|c|}
\hline \multirow[b]{2}{*}{ Intustryi: $: \because$} & \multirow[b]{2}{*}{ Factlity type } & \multirow[b]{2}{*}{ Process (equipment) } & \multicolumn{3}{|c|}{ Entssians, $16 /$ ton $^{3}$} \\
\hline & & & ${ }^{100}{ }_{x}$ & $\mathrm{SO}_{\mathrm{k}}$ & HC \\
\hline clay products & $\begin{array}{l}\text { Brick and tile } \\
\text { Lightielght aggregate }\end{array}$ & 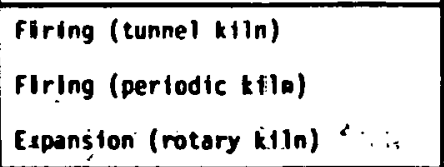 & $\begin{array}{l}\text { Gos: } 1.50 \times 10^{-1 b} \\
\text { Gos: } 4.20 \times 10^{-1 b} \\
\text { Coos } 1: 1.2^{b}\end{array}$ & $\begin{array}{l}1.44 \times 10^{-3 e} \\
1.44 \times 10^{-3 e} \\
3.2(5)^{6.6}\end{array}$ & $\begin{array}{l}2.00 \times 10^{-26} \\
1.00 \times 10^{-2} 0 \\
1.00 \times 10^{-2} b\end{array}$ \\
\hline Cesent & $\begin{array}{c}\text { Cemen! } \\
\vdots \\
\vdots\end{array}$ & $\begin{array}{c}\text { Calcination (rotory } h i 1 n \text { ). } \\
\vdots \\
\vdots\end{array}$ & $\begin{array}{l}\text { 011: } f \\
\text { Gas: } f \\
\text { Cosl: }{ }^{\prime} 2.6^{b}\end{array}$ & $\begin{array}{l}4.2(5)^{b . c}: \\
2.26 \times 10^{-3}= \\
6.8(5)^{t .0} \therefore\end{array}$ & $\begin{array}{l}1.11 \times 10^{-1} \mathrm{e} \\
3.16 \times 10^{-2} \times \\
2.2 \times 10^{-2}\end{array}$ \\
\hline Gless & $\begin{array}{l}\text { Container glass } \\
\text { Flat glass } \\
\text { Pressed and blown } \\
\text { glass }\end{array}$ & $\begin{array}{l}\text { Meliting (furnace) } \\
\vdots \\
\text { Melting (furnace) } \\
\vdots \\
\text { Melting (fumace) }\end{array}$ & $\begin{array}{l}\text { Gos: } 6.2^{b} \\
\text { Gas: } 8.0^{b} \\
\text { Gas: } 8.5^{b}\end{array}$ & $\begin{array}{l}3.03 \times 10^{-3}= \\
7.13 \times 10^{-3}= \\
1.37 \times 10^{-2}=\end{array}$ & $\begin{array}{l}2.0 \times 10^{-1} b \\
1.0 \times 10^{-1} b \\
3.0 \times 10^{-1}\end{array}$ \\
\hline Dlatonite & Diatonlte & Drying/calcination (calciner) & & & \\
\hline $\begin{array}{r}\text { Mineral wool } \\
: \quad \cdot \quad \therefore\end{array}$ & $\begin{array}{l}\text { Mineral wool :.: } \\
\text { Fibergigss . wool }\end{array}$ & $\begin{array}{l}\text { Matural rock or slas wool melt- } \\
\text { Ingl (cupole) } \\
\text { Fiserglass, wool melting (re- } \\
\text { cuperat Ive furnace) }\end{array}$ & $\begin{array}{l}\text { Coke: } 2.67^{n} \\
\text { Gos: } 5.0^{n}\end{array}$ & $29.1^{e}$ & $3.76 \times 10^{-2}$ \\
\hline Iron and steel & $\begin{array}{c}\begin{array}{c}\text { Integrated iron and } \\
\text { steel }\end{array} \\
\vdots \\
\cdot\end{array}$ & 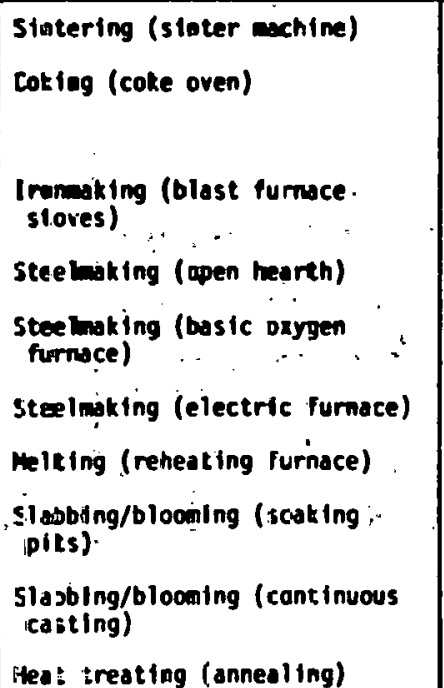 & $\begin{array}{l}1.816 / \text { ton sinter" } \\
1.8916 / \text { ton coke } \\
3.40 \times 10^{-1} 16 / \text { ton pig } \\
\text { ironf } \\
\text { Gas: } 4.50^{\mathrm{p}} \\
\text { Gas: } \mathrm{f} \\
\text { Gas: } 9.0 \times 10^{-3} \mathrm{p} \\
1.10^{\mathrm{P}} \\
8.0 \times 10^{-1} \mathrm{p} \\
\text { Gos: } \mathrm{P} \\
\text { Gas: } \mathrm{P}\end{array}$ & 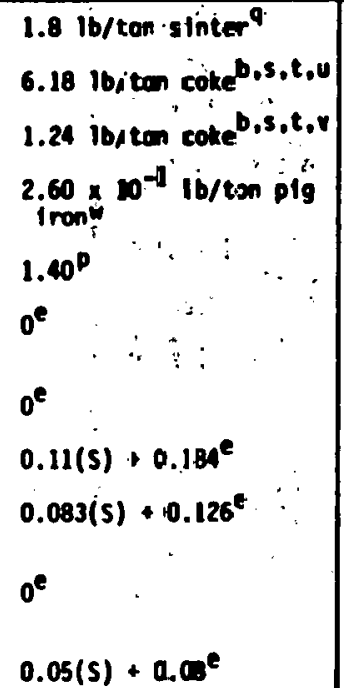 & 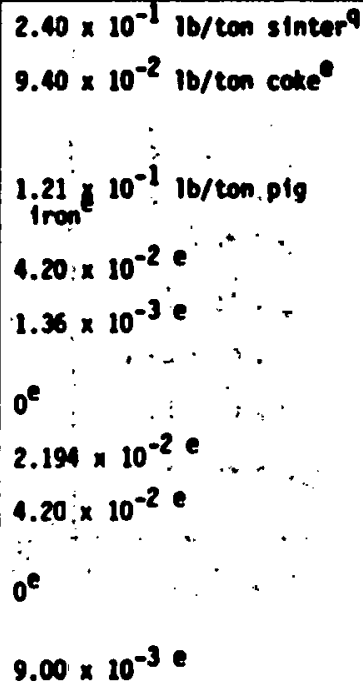 \\
\hline
\end{tabular}

(continued) 
TABLE 2-1 (continued)

\begin{tabular}{|c|c|c|c|c|c|}
\hline \multirow[b]{2}{*}{ Industry } & \multirow[b]{2}{*}{ Focility type } & \multirow[b]{2}{*}{ Process (equtponent) } & \multicolumn{3}{|c|}{ Emissions, $10 /$ ton } \\
\hline & & & No $x$ & ${ }^{50} x$ & HC \\
\hline $\begin{array}{l}\text { Iron and steel } \\
\text { (cont inved) }\end{array}$ & $\begin{array}{l}\text { Mini and midi stee? } \\
\text { plantsm } \\
\text { Coke plants" } \\
\text { Iron foundries: }\end{array}$ & $\begin{array}{l}\text { Steelmaking (open hearth) } \\
\text { Steelmaking (electric furnace) } \\
\text { Melting (reheating furnace) } \\
\text { slabbing/blooning (soaking pits) } \\
\text { Heat treating (annealing) } \\
\text { Coking (coke oven) } \\
\text { Helting (cupola). }\end{array}$ & $\begin{array}{l}4.50^{p} \\
9.00 \times 10^{-3} p \\
1.1^{p} \\
8.00 \times 10^{-1} p \\
1.8910 / \text { ton coke } \\
\text { Coke: } 1.10 \times 10^{-1} !\end{array}$ & 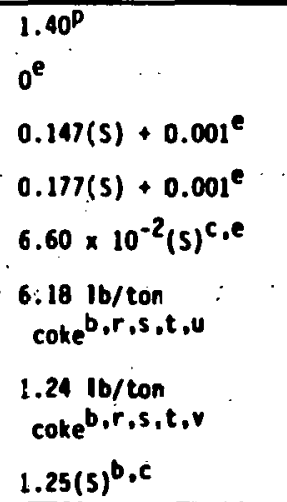 & $\begin{array}{l}1.41 \times 10^{-2} \mathrm{e} \\
1.00 \times 10^{-3} \mathrm{e} \\
1.60 \times 10^{-2} \mathrm{e} \\
1.10 \times 10^{-2} \\
7.00 \times 10^{-3} \\
9.40 \times 10^{-2} \\
16 / \text { ton coke } \\
0^{b}\end{array}$ \\
\hline $\begin{array}{l}\text { Primary nonterrous } \\
\text { etals }\end{array}$ & $\begin{array}{l}\text { Aluminumi sanel ters } \\
\text { Copper smelters and } \\
\text { refinertes }\end{array}$ & $\begin{array}{l}\text { Anode bak Ing (ring furnace) } \\
\text { Smelting (dryer) . . } \\
\text { Smelting (reverberatory furnace) } \\
\text { Smelțing (converter). } \\
\text { fire refining (anode furnace) }\end{array}$ & $\begin{array}{l}\text { Gos: } f \\
\text { Gas: } f \\
\text { 011: } \\
\text { Gas: } f \\
\text { 011: } f \\
\text { Gas: } f \\
\text { O11: } f \\
\text { Gas: } f \\
\text { Cosl: } 8.84 \times 10^{-5} b \\
\text { Gos: } f \\
\text {. . }\end{array}$ & $\begin{array}{l}8.51 \times 10^{-4} b \\
5.56 \times 10^{-4} e_{, x} \\
12.3(s)^{c, e, x} \\
5.24 \times 10^{-3} e_{, x} \\
4.4 \times 10^{-2}(s)^{c, e_{0} x} \\
3.48 \times 10^{-4} e_{, x} \\
2.55 \times 10^{-1}(5)^{c, x} \\
1.288 \times 10^{-3} e_{, x} \\
1.02 \times 10^{-4}(s)^{b, c} \\
1.76 \times 10^{-4} e_{.} x\end{array}$ & $\begin{array}{l}1.43 \times 10^{-2} b \\
9.58 \times 10^{-3} \\
2.266 \times 10^{-1} \\
8.576 \times 10^{-2} \\
4.64 \times 10^{-3} \\
5.82 \times 10^{-3} \\
\vdots .64 \times 10^{-3} \\
2.148 \times 10^{-2} \\
1.626 \times 10^{-4} \\
1.27 \times 10^{-3}\end{array}$ \\
\hline
\end{tabular}

\section{(continued)}




\section{TABLE 2-1 (continued)}

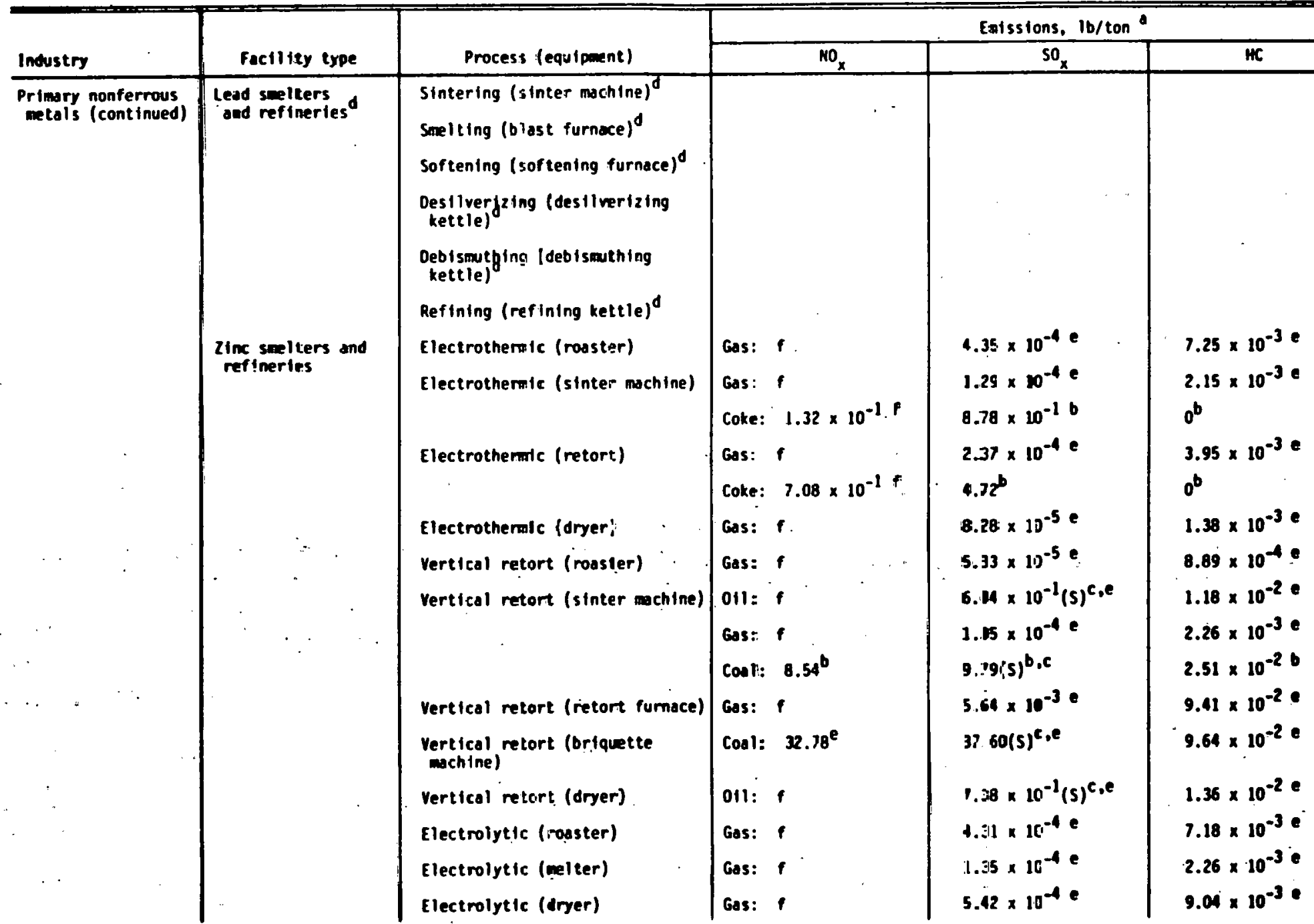

\section{(continued)}


TABLE 2-1 (continued)

\begin{tabular}{|c|c|c|c|c|c|}
\hline \multirow[b]{2}{*}{ Industry } & \multirow[b]{2}{*}{ foctlley type } & \multirow[b]{2}{*}{ Process (equipment) } & \multicolumn{3}{|c|}{ Enissions, $16 /$ ton } \\
\hline & & & ${ }^{10}{ }_{x}$ & so $_{x}$ & MC \\
\hline $\begin{array}{c}\text { Priagry. nonferrous } \\
\text { metals (continued) } \\
\vdots\end{array}$ & 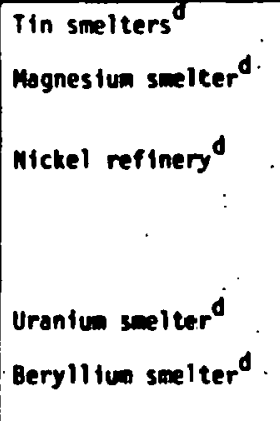 & $\begin{array}{l}\text { Snelting (blast furnace) } \\
\text { Calcinatign (reverberatory } \\
\text { furnace) } \\
\text { saeltigg (reverberatory fur- } \\
\text { nace) } \\
\text { Reduct ionj (reverberatory } \\
\text { furnace) } \\
\text { Drying (dryer) } \\
\text { Briquettigg/sintering (sinter } \\
\text { machine) }\end{array}$ & & $\vdots$ & $\begin{array}{l}: \\
\\
\therefore . \\
\therefore .\end{array}$ \\
\hline $\begin{array}{l}\text { Secondary nonferrous } \\
\text { metals }\end{array}$ & $\begin{array}{l}\text { Secondary copper } \\
\text { smelter and refin- } \\
\text { eries } \\
\end{array}$ & $\begin{array}{l}\text { Sweating (sweating furnace) } \\
\text { Smelting (reverberotory furnace) } \\
\text { sweating (sweat ing furnace) } \\
\text { Sneiting (blast furnace) } \\
\text { Swelting (reverberatory furnace) } \\
\text { Refining (reverberatory furnace) }\end{array}$ & 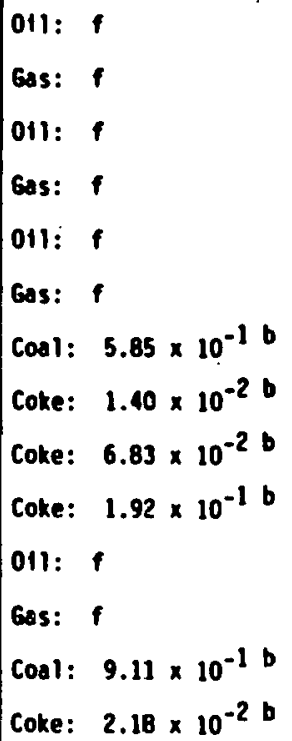 & $\begin{array}{l}1.46(s)^{c, e} \\
5.37 \times 10^{-4} \mathrm{e} \\
7.67(s)^{c, e} \\
2.83 \times 10^{-3} \mathrm{e} \\
4.78 \times 10^{-1}(s)^{c, e} \\
1.76 \times 10^{-4} \mathrm{e} \\
6.71 \times 10^{-1}(s)^{b, c} \\
9.46 \times 10^{-2} \mathrm{~b} \\
4.62 \times 10^{-1} \mathrm{~b} \\
1.30^{b} \\
7.44 \times 10^{-1}(s)^{c, e} \\
2.75 \times 10^{-4} \mathrm{e} \\
1.05(5)^{b, c} \\
1.47 \times 10^{-1} \mathrm{~b}\end{array}$ & $\begin{array}{l}2.64 \times 10^{-2} \mathrm{e} \\
8.96 \times 10^{-3} \mathrm{e} \\
1.39 \times 10^{-1} \mathrm{e} \\
4.12 \times 10^{-2} \mathrm{e} \\
8.67 \times 10^{-3} \mathrm{e} \\
2.94 \times 10^{-3} \mathrm{e} \\
1.72 \times 10^{-3} \mathrm{~b} \\
0^{b} \\
0^{b} \\
0^{b} \\
1.35 \times 10^{-2} \mathrm{e} \\
4.58 \times 10^{-3} \mathrm{e} \\
2.68 \times 10^{-3} \mathrm{~b} \\
0^{b}\end{array}$ \\
\hline
\end{tabular}

(continued) 
TABLE 2-1 (continued)

\begin{tabular}{|c|c|c|c|c|c|}
\hline \multirow{2}{*}{ Indenstry } & \multirow[b]{2}{*}{ Factlity type } & \multirow{2}{*}{ Process (equipsient) } & \multicolumn{3}{|c|}{ Enissions. $16 /$ ton } \\
\hline & & & $\mathrm{NO}_{\mathrm{x}}$ & $\mathrm{SO}_{\mathrm{x}}$ & m \\
\hline $\begin{array}{l}\text { Secondary nonferrous } \\
\text { metals (cont Inued) }\end{array}$ & $\begin{array}{l}\text { Secondary lead } \\
\text { smelters }\end{array}$ & $\begin{array}{l}\text { Smelting (t.last furnace) } \\
\text { Smelting (reverberatory furnace) }\end{array}$ & $\begin{array}{l}\text { Coke: } 5.33 \times 10^{-26} \\
\text { 011: } f \\
\text { Gas: } f\end{array}$ & $\begin{array}{l}3.61 \times 10^{-16} \\
5.29(5)^{c . e} \\
1.35 \times 10^{-3} \mathrm{e}\end{array}$ & $\begin{array}{l}0^{b} \\
9.6 \times 10^{-2} \\
3.25 \times 10^{-2}\end{array}$ \\
\hline Aluminum fabrication & $\begin{array}{l}\text { Aluminum sheet. } \\
\text { plate, ard foil }\end{array}$ & $\begin{array}{l}\text { Melting (reverberatory furnace) } \\
\text { Heat treat ing (heat treating } \\
\text { furnace) }\end{array}$ & $\begin{array}{l}\text { Gas: } f \\
\text { Gas: } f\end{array}$ & $\begin{array}{l}4.51 \times 10^{-3} \mathrm{e} \\
5.58 \times 10^{-3} \mathrm{e}\end{array}$ & $\begin{array}{l}1.52 \times 10^{-2} e \\
9.3 \times 10^{-2} e\end{array}$ \\
\hline
\end{tabular}

Enisstion factors expressed in units of pounds per ton of product unless spectfied otherwise.

U.S. Enviromental frotection Agency. Compilation of the Air Pollutant Emission Factors. 3rd Ed. (including Supplements 1 through 13 ), Ap-42. c Research Triangle Park. Worth Carolina, 1977 .

is is the meight percent sulfur in the fue

Plant/process located outside study area; thus, enission factors mere not assigned to this facility type.

U.S. Environmental Protection Agency. Atr Pollution Engineering Manual. 2nd Ed., Ap-40. Research Triangile Part, Morth Carolina, 1973.

Millis, J. L.. et al. Enissions of Oxides of Mitrogen from Stationary Sources in Los Angeles County. Report Mo. A. Prepared for the Los Angeles County APCD. LOS Angeles, Califfornia, 1961.

9 U.S. Bureau of Mines. Interim Repart on Energy Use Pattems in Retallurgical and Monmetallic Minaral Processing. Battelle Colunbus Laboratories, $n$ September 1975.

For. Ho. 5 fuel oll haviag sulfur content less than 18 by welght.

For Mo. 5 fuel ofl hoving sulfur cantent greater than ix by welght.

For Mo. 6 fuel oil having sulfur content greater than is by weight.

For coal having sulfur content less than is by weight.

For coal having sulfur content grealer than is by weight.

U.S. Environmental Protection Agency. Source Category Survey: MIneral Mool Manufacturing Industry. EPA-150/3-E0-016. Research Triangle Parth,

n W.S. Environaental Protection dgency. Glass Manufacturing Plants. Background Informetion: Propesed Stancards of Performance. EPA-450/3-79-005a. - Research Triangle Park, North Carolina, June 1979.

Acurex. Enission Characterization of Stationary MO fael(s) consumed in processes. (Appendix A). Research Triangle Part. North Carolina. 1978. 9 PEDCa Environmental, Inc. Developant of Air Pollution Control Cost Functions for the Integrated-I:no and Steel Industry. EPA Mo. 68-01-4600, Juily

J.S. Envtronmental Protection higency. Draft EIS. Coke Oven Battery Stacks. Mashington, D.C., 1980.

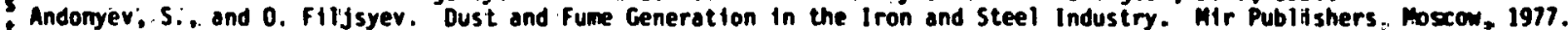

uEOCa Environmental. Inc. Cost EIfectiveness Nodel for Pollution Control at Coking Facilitles. EPA-600;2-79-185, August 1979.

$\checkmark$ For mondesulfurized coke oven gas.

W. Elast Fumace Cast House Eaisston Control Technology Assessment, Epa-500/2-71-231, 1971.

x.Aine. Extractive. Metallurgy of Copper, Volume 1, Pyrometallurgy and Electrolytic Refining. . New York, ists. 
the industrial energy data base. These references provided extensive coverage of' major energy-consuming industries. 'Each primary reference was used as a backup for the Census analysis described in Appendix $B$ and as a source of industries for possible inclusion in the data base. The supplemental references (1-8) provided additional processing and production information. The eight primary references are:

- Radian Corporation. Energy Use Patterns and Environmental. Implications of Direct-Fired.Industrial Processes. Prepared for U.S. Department of Energy, Washington, D.C. DCN 79-230-139-20-03, April 1980:

- Battelle Columbus Laboratories. Energy Use Patterns in Metallurgical and Nonmetallic Mineral Processing. Prepared for the Bureau of Mines, Washington, D.C. 1975 .

- Institute of Gas Technology. Study of Industrial Uses of Energy Relative to Environmental Effects. . Prepared for U.S. Environmental Protection Agency, Research Triangle Park, North Carolina. 1974.

- Institute of Gas Technology. Survey of Emission Control and Combustion Equipment Data in Industrial Process Heating. EPA-600/7-76-002, 1976.

- Energy and Environmental Analysis, Inc. The Technical Feasibility of Coal Use in Industrial Heat Applications. Washington, D.C. DOE EJ-78-C-01-28.32, 1978.

- PEDCo Environmental, Inc. Control Techniques for Sulfur Oxide Emissions from Stationary Sources. 1981.

- PEDCo Environmental, Inc. Characterization of DirectFired Industriàl Processes. Prepared for Department of Energy; Morgantown, West Virginia." 1981 .

- Drexel University.: Energy Analysis of 108 Industrial Processes. Prepared for the U.S. Department of EnergY, Contract No. E(11-1) 1862, Washington, D.C. 1980.

The following is a brief description of these references in terms of their usefulness and limitations for the development of the direct-fired energy data base: 
The Radian study ${ }^{1}$ analyzed on a national basis, the amount of direct-fired energy consumed by 130 individual processes, ranked these processes according to significance, and compared them with other types of energy consumption in the industrial manufacturing segment. Results indicated that 70 percent of the annual direct-fired energy consumption was accounted for by specific manufacturing processes within the six most energyintensive industry groups. This report provided a means of checking'for comprehensive coverage of direct-fired processes and a source of energy data for determining the relative importance of specific direct-fired industrial processes.

The Battelle report ${ }^{2}$ provides an extensive analysis of energy consumption in the mineral processing and metallic industries. It assesses energy consumption (including steam and electrical) within 85 industries and ranks these industries according to their significance. Twenty-one of these industries have been incorporated into the direct-fired energy data base. The remaining industries were dropped from consideration because they principally use steam or electricity rather than fossil fuels. Although this report was a valuable source of energy data in the mineral processing and metallics industries, it provided no data for other manufacturing categories (such as textiles, food, or chemicals). Also, it provided only national totals and did not analyze the data geographically.

The 1974 Institute of Gas Technology (IGT) report ${ }^{3}$ examines energy utilization patterns and air pollutant emissions in 12 
industry groups. This report was used as an aid in analyzing the ratio of fuel use in boilers to that used in direct-fired processes. In addition, all industries examined in this report were reviewed for possible inclusion in the energy data base. The 1976 IGT report ${ }^{4}$ considers six major fuel burning sources. Although not as broad in scope as the earlier report by IGT, each industry is studied in greater depth. Each of the six industries analyzed was incorporated into the direct-fired energy data base. Neither of the two IGT reports analyzed the energy data geographically.

The Energy and Environmental Analysis (EEA) report ${ }^{5}$ considers the feasibility of substituting coal in industrial process heat applications. This report is relatively comprehensive in both its scope and depth of analysis. Analysis of the data presented resulted in incorporation of 11 of the 22 industries analyzed into the direct-fired data base. The others were principally consumers of steam or electricity. This report reviewed data only at the national level and did not examine any findings at the local, state, or regional levels.

The PEDCo $\mathrm{SO}_{\mathrm{x}}$ Control Techniques document ${ }^{6}$ concentrates on So $_{x}$ emissions and their control. This document provides useful processing and energy data on the 12 industries with significant $\mathrm{SO}_{2}$ emissions (e.g., smelters, sulfuric acid plants, etc.). It was used both as a checklist and a source of pertinent production, processing, and energy data.

PEDCo's Industrial Direct-Fired Process Characterization report ${ }^{7}$ documents energy use in major direct-fired industrial 
processes by pulling together data from a number of the other references mentioned here. Although this report does not provide a great deal of detail in its analysis, the in-house file used to compile this report was used as a starting point for a number of the industries analyzed.

The Drexel study ${ }^{8}$ provides an energy analysis of 108 major industries. The data presented are theoreticaliy based on material and energy balances. This report proved usetul both as a checklist and as an indicator of the quantity of direct-fired energy consumed within specific industrial processes. Because the report provided little or no text qualifying its assumptions and lacked sufficient documentation, it was not used extensively beyond the preliminary industry analysis.

A number of supplementary documents provided information on capacity, production, plant population and location, emissions, and processing techniques. The key supplementary. references $(9-17)$ are:

- Kirk-Othmer. Encyclopedia of Chemical Technology. Volumes 1-20. 3rd Ed. John Wiley \& Sons, New York. 1980 .

$n$ SRI International, 1982 Dirootory of Chemical Producers. Menlo Park, California, 1982.

- U.S. Department nf the Interior. Minerals Yearbook Volume 1. Metals and Minerals. Bureau of Mines. Washington, D.C. 1980.

- U.S. Environmental Protection Agency. Industrial Process Profiles for Environmental Use. Chapters 1-29. EPA-600/2-77-023, 1977.

- U.S. Environmental Protection Agency. Compilation of the Air Pollutant Emission Factors. 3rd Ed. Research Triangle Park, North Carolina. AP-42, 1977. 
- U.S. Environmental Protection Agency. Air Pollution Engineering Manual: Research Triangle Park, North Carolina. AP-40 1973.

- U.S. Environmental Protection Agency. Aeros Manual Series. Volume V: Aeros Manual of Codes. Research Triangle Park, North Carolina. EPA-450/2-76-005. 1976.

- U.S. Environmental Protection Agency. Source Assessment Reports. Contract EPA-68-02-1874.

- U.S. Environmental Protection Agency. Source Category Survey Reports. Contract EPA-450/3-80-001 and series.

A review of all of the documents used made it obvious that the chemical and chemical processing industries are the least documented and quantified because of their complex structure and variety of products. Thus, as an additional check on the coverage, all chemicals having production capacities of $>500 \times 10^{6} 1 \mathrm{~b} / \mathrm{yr}$ were identified, 10 and the resulting list (135 chemicals) was reviewed to determine if any of the chemical manufacturing processes identified as direct-fired would meet or exceed the $100 \times 10^{9} \mathrm{Btu} / \mathrm{yr}$ cutoff. No processes were added as a result of the investigation; hence, it was concluded that coverage of chemical production processes was adequate.

Direct-fired source emission factors--The list of direct-

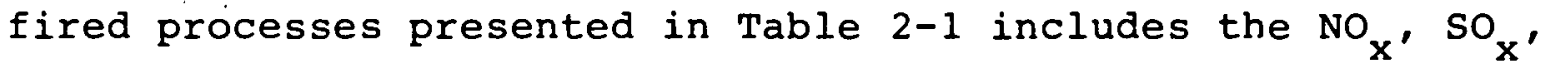
and HC emission factors used in the emission estimates. A more complete explanation of emission factors and associated assumptions is contained in the individual methodologies presented in Appendix A. When available, emission factors from published data (mostly from EPA's $A P-42)^{13}$ were used, but general industrial combustion source emission factors (mostly from AP-40, an 
earlier set of factors generated for Los Angeles County) ${ }^{14}$ were used to provide some estimate of emissions for a substantial number of processes.

Only combustion-related emissions were calculated, and for a number of processes, this meant separating out the combustion component from an existing emission factor that included both process and combustion emissions (e.g., carbon black, 'glass melting furnaces, and coke ovens).

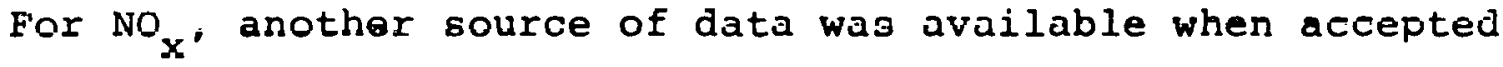
emission factors could not be located. In these cases, the emission factor graphs shown in Figures 2-1 and 2-2 were used to calculate $\mathrm{NO}_{\mathbf{x}}$ emissions for oil- and gas-fired processes. These graphs are based on heat input per hour and fit the following equations that were used for computations.

$$
\begin{aligned}
& \text { Gas: } y(1 \mathrm{~b} / \mathrm{h})=9.04 \times 10^{-9} \times(\mathrm{Btu} / \mathrm{h}) 1.17 \\
& \text { Oil: } y(1 \mathrm{~b} / \mathrm{h})=1.62 \times 10^{-8} \times(\mathrm{Btu} / \mathrm{h}) 1.17
\end{aligned}
$$

Industrial Boilers--

There are tens of thousands of boilers in the industrial sector in the eastern United states. The vast majority are small in size. Very little information has been published on the demographics of small boilers; most of the existing inventories have concentrated on large boilers. Because of the lack of data and the scope of this study, only large industrial boilers were analyzed (i.e., those with capacities of at least $250 \times 10^{6} \mathrm{Btu} / \mathrm{h}$ and fuel consumption greater than $100 \times 10^{9}$ Btu(yr). Fuel and emissions thought to be representative of the 


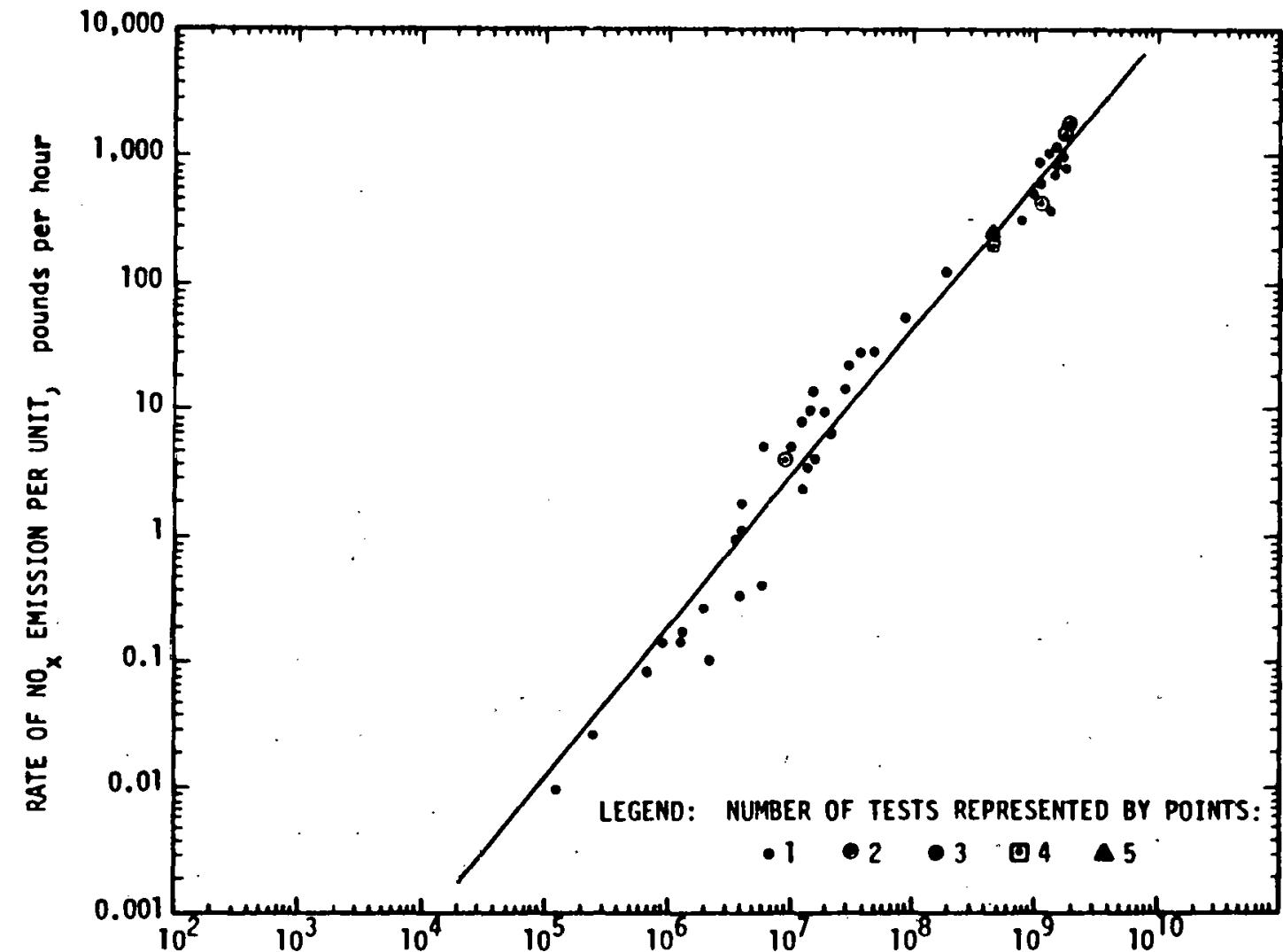

OIL-FIRED EQUIPMENT: RATE OF TOTAL GROSS HEAT INPUT TO A UNIT, Btu per hour

Figure 2-1. Graph for estimating $\mathrm{NO}_{\mathrm{x}}$ emissions from oil-fired equipment. ${ }^{18}$ 


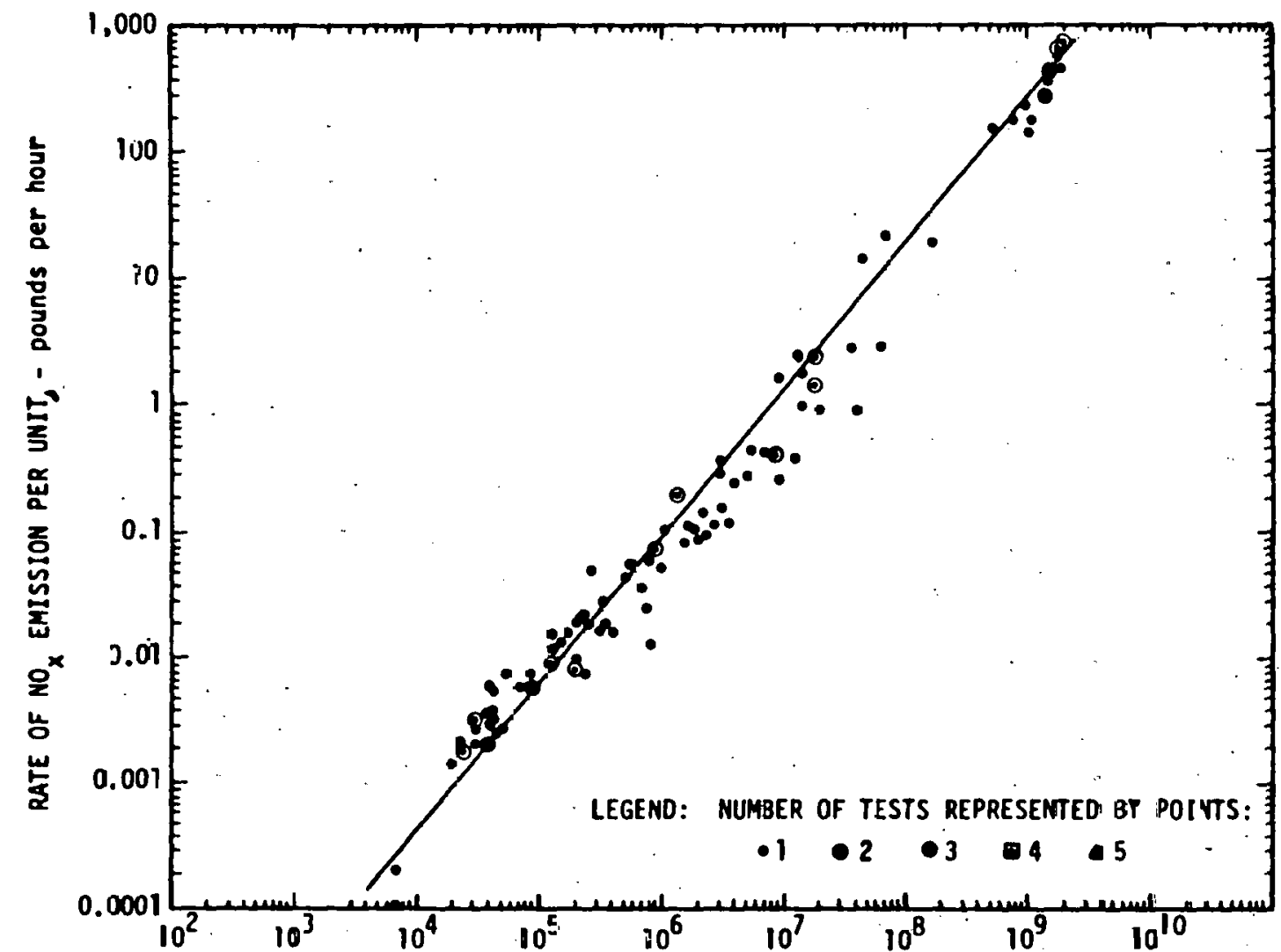

GAS-FIRED EQUIPMENT: RATE OF TOTAL GROSS HEAT.INPUT TO A UNIT, Gtu per hour

Figure 2-2. Graph for estimating $\mathrm{NO}_{\mathrm{x}}$ emissions from gas-fired equipment. ${ }^{18}$ 
smalier boilers are included in the industrial area source component of the industrial sector.

Results of a previous study ${ }^{19}$ indicated only two principal sources of data on large industrial boilers in the United States.

- The National Emission Data System (NEDS) maintained by the U.S. Environmental Protection Agency.

- The Major Fuel Burning Installation (MFBI) survey conducted by the U.S. Department of Energy in the mid-1970.'s.

Although discrepancies exist between these sources, and both sources are known to have limitations, they were utilized as the basis of the industrial boiler population that was generated.

Current NEDS printouts were obtained from EPA's office of Air Quality Planning and Standards, and an MFBI listing was provided by Argonne National Laboratory. Other in-house data and literature data were used to check the NEDS and MFBI data or provide missing information, where possible.

The National Emission Data System proved to be the more comprehensive source of information in terms of numbers of boilers, firing mechanisms, and fuel types reported. When differences were evident, the NEDS data were used as the primary source, and the information from MFBI was used as needed to characterize sources not found in NEDS.

Boilers in the study area with capacities equal to or greater than $250 \times 10^{6} \mathrm{Btu} / \mathrm{h}$ were identified from the data sets. Units in the utility, commercial, or institutional sectors were screened out to avoid duplication in the data base. Fuel types and guantities were recorded, and a capacity factor was calculated for each listing to identify any fuel data that might be erroneous. 
When the calculated capacity factor exceeded 100 percent, the fuel quantity was adjusted downward to achieve a more realistic 50 percent figure. The impact of this assumption on the results of the analysis is believed to be minimal, since this only occurred in a few instances.

It was not always possible to accurately identify individual units from the NEDS and MFBI data. Since the NEDS information is organized by emission point (i.e. stack), it is possible that some small boilers were combined and shown as a boiler $>250 \mathrm{x}$ $10^{6} \mathrm{Btu} / \mathrm{h}$. "In the MFBI survey multifuel boilers may be reported more than once.

The results of this analysis reflect total fuel consumption for all boilers with capacities of at least $250 \times 10^{6} \mathrm{Btu} / \mathrm{h}$ at each facility; the data from these boilers are combined and presented on a facility basis.

Emission factors for industrial boilers were obtained from EPA publications. ${ }^{13,20}$ Table 2-2 lists the factors that were used. Emissions for each boiler facility were then calculated by multiplying the emission factors for $\mathrm{SO}_{x}, \mathrm{NO}_{x}$, and $\mathrm{HC}$ by the appropriate fuel consumption.

Industrial Area Sources--

The industrial area source category includes all fuel use and emissions not associated with large point sources and boilers having fuel consumption over $100 \times 10^{9} \mathrm{Btu} / \mathrm{yr}$. Thus, this category consists of small industrial boilers $\left(<250 \times 10^{6} \mathrm{Btu} / \mathrm{h}\right)$, small direct-fired combustors, and gas turbines and IC engines. The relative breakdown of these components was not investigated. 
TABLE 2-2. LARGE INDUSTRIAL BOILER EMISSION FACTORS ${ }^{13,20}$

\begin{tabular}{|c|c|c|c|}
\hline Fuel/Firing Configuration & ${ }^{\mathrm{N} O}{ }_{x}$ & $\mathrm{so}_{\mathrm{x}}$ & HC \\
\hline Coal/pulverized wet bottom & $34 \mathrm{lb} /$ ton & $39(\mathrm{~s}) \mathrm{lb} /$ ton & $\therefore 0.1 \mathrm{lb} /$ ton \\
\hline Coal/pulverized dry bottom & $21 \mathrm{lb} /$ ton & $39(s) 1 b /$ ton & $0.1 \mathrm{lb} /$ ton \\
\hline Coal/cyclone furnace & $37 \mathrm{lb} /$ ton & 39 (S) $1 \mathrm{~b} /$ ton & $0.1 \mathrm{lb} /$ ton \\
\hline Coal/spreader stoker & $14 \mathrm{lb} /$ ton & 39 (S) $1 \mathrm{~b} /$ ton & $0.1 \mathrm{lb} /$ ton \\
\hline Coal/other stoker & $7.5 \mathrm{lb} /$ ton & $39(\mathrm{~s}) 1 \mathrm{~b} /$ ton & $0.1 \mathrm{lb} /$ ton \\
\hline Residual oil & $67 \mathrm{lb} / 10^{3} \mathrm{gal}$ & $159.9(S) .1 \mathrm{~b} / 10^{3} \mathrm{gal}$ & $1.04 \mathrm{lb} / 10^{3} \mathrm{gal}$ \\
\hline Distillate oil & $201 \mathrm{~b} / 10^{3} \mathrm{gal}$ & 144 (S) $1 \mathrm{~b} / 10^{3} \mathrm{gal}$ & $0.252 .1 \mathrm{~b} / 10^{3} \mathrm{ga} 1$ \\
\hline Natural gas & $550 \mathrm{lb} / 10^{6} \mathrm{ft}^{3}$ & $0.6 \mathrm{lb} / 10^{6} \mathrm{ft}^{3}$ & $1.7 \mathrm{lb} / 10^{6} \mathrm{ft}^{3}$ \\
\hline Process gas & $550 \mathrm{lb} / 10^{6} \mathrm{ft}^{3}$ & $950(\mathrm{~s}) 1 \mathrm{~b} / 10^{6} \mathrm{ft}^{3}$ & $1.7 \mathrm{lb} / 10^{6} \mathrm{ft}^{3}$ \\
\hline Wood & $2.8 \mathrm{lb} /$ ton & $0.148 \mathrm{lb} /$ ton & $1.7 \mathrm{lb} /$ ton \\
\hline Bagasse & $1.2 \mathrm{lb} /$ ton & 0 & $2 \mathrm{lb} /$ ton \\
\hline
\end{tabular}


For determination of industrial area source fuel use within. each state, the total fuel consumption in each of the eight fuel categories accounted for by the industrial direct-fired and boiler categories was subtracted from the total reported in the State Energy Data Base. 21 The industrial area source totals for. the state were then allocated into individual counties in direct proportion to the number of manufacturing establishments in each county, as reported by the Bureau of Census. 22 The factors reported in Table $2-3$ were used to calculate emissions.

TABLE 2-3. INDUSTRIAL AREA SOURCE EMISSION FACTORS ${ }^{13}$

\begin{tabular}{l|c|c|c}
\hline \multirow{2}{*}{ Fuel } & \multicolumn{3}{|c}{ Emission Factor, 1b/10 } \\
\cline { 2 - 4 } & $\mathrm{NO}_{\mathrm{x}}$ & $\mathrm{SO}_{\mathrm{x}}$ & $\mathrm{HC}$ \\
\hline Coal & 1.36 & $1.56(\mathrm{~S})$ & 0.004 \\
Residual oil & 0.133 & $1.1(\mathrm{~S})$ & 0.0202 \\
Distillate oil & 0.144 & $1.19(\mathrm{~S})$ & 0.0218 \\
Natural gas & 0.209 & 0.00041 & 0.00684 \\
\hline
\end{tabular}

$(S)=$ Sulfur content of fuel on a state basis.

It should be noted that follow-up efforts to this project have shown that some of the states in SEDB have coking coal included in their industrial coal totals. In future studies, this portion of the coal total will be subtracted, to avoid double counting of emissions already covered in the direct-fired portion of the industrial sector.

\section{1 .3 Utility Sector}

Energy and emission estimates for 1980 were based on fuel use data provided by Ed Pechan and Associates in hard copy form, for the $800+$ utility plants located in the eastern United States. 23 This data set, which combines information from a number of 
different sources of utility data [i.e., FPC-67, DOE's Generating Unit Reference File (GURF), DOE Form 423, etc.], was believed to reflect the best compilation of available data.

Pechan provided energy data for each plant for the three major fuel types: coal, residual oil, and natural gas. The data also included sulfur oxides emissions for each plant, based on the fuel mix. A sample data sheet from the Pechan data base is shown in Figure $2-3$.

The plant listing provided by Pechan was cross-checked with a 1981 listing from GURF $^{24}$ and a 1982 listing of utility generating plants obtained from DOE's Energy Information Administration (EIA) in order to locate a number of plants that were left unnamed in the Pechan data base and to provide county locations for all of the utility plants. In examining the EIA data it was noted that a number of plants contained in the Pechan data base had been retired. Since these plants burned no fuel in 1980 , they were eliminated from the data base.

Energy consumption by fuel was calculated as follows:

1). For coal, the consumption and heating value reported by Pechan were utilized.

2) For residual oil and natural gas, consumption was reported but heating values were not reported; hence, the consumption reported by Pechan was multiplied by assumed heating values of $150,000 \mathrm{Btu} / \mathrm{gal}$ and 1,000 Btu/ft ${ }^{3}$, respectively.

Sulfur oxide, $\mathrm{NO}_{x}$, and $\mathrm{HC}$ emissions were then calculated. Calculations were based on emission factors obtained from AP-42, which are summarized in Table 2-4.

These latest AP-42 emission factor values for $\mathrm{SO}_{\mathbf{x}}$ differ from the sulfur values presented in the Pechan data. The $\mathrm{SO}_{\mathbf{x}}$ 


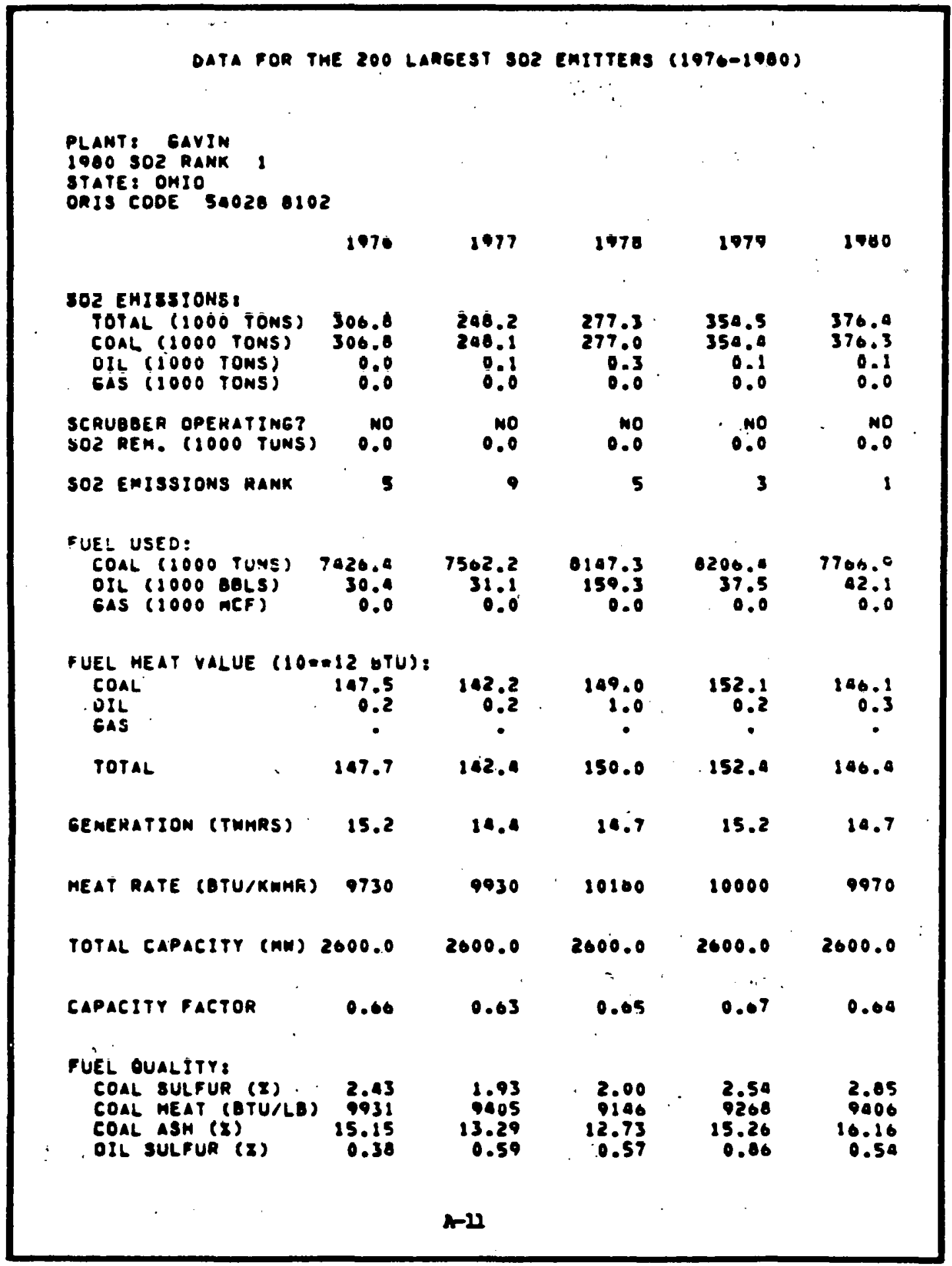

Figure 2-3. Sample data sheet from Pechan data base. 
emission factor of $39(\mathrm{~S}) \mathrm{lb} / \mathrm{ton}$ [as opposed to $38(\mathrm{~S})$ used by Pechan] is based on the use of a bituminous coal and was used for the present study. Because the coals considered were predominantly of Eastern origin, we did not differentiate the emission factor for subbituminous or lignite coals. The AP-42 $\mathrm{SO}_{\mathrm{x}}$ emission factor for subbituminous coal is $35(\mathrm{~s}) 1 \mathrm{~b} /$ ton [as opposed to 34 (S) $1 \mathrm{~b} /$ ton used by Pechan], and the factor for lignite is $30(\mathrm{~S}) \mathrm{lb} / \mathrm{ton}$ (same as Pechan). While differences in these factors are significant, inspection of the data indicated that adjusting the $\mathrm{SO}_{\mathrm{x}}$ emission factor for individual study area coals would make only a small difference; hence, no refinement was included.

TABLE 2-4. UTILITY PLANT EMISSION FACTORS ${ }^{13}$

Fue 1

Coal

$0 i 1$

Natural gas

${ }^{a} s=$ percent sulfur.

\section{Emission factors}

$\mathrm{NO}_{\mathrm{X}}$

$\mathrm{SO}_{x}^{\mathrm{a}}$

39 (S) $16 /$ ton

$18 \mathrm{lb} / \mathrm{ton}$.

$54.5 \mathrm{lb} / 1000 \mathrm{gal}$

159.9 (S) $1 \mathrm{~b} / 1000 \mathrm{gal}$

$0.6 \mathrm{lb} / 10^{6}: \mathrm{ft}^{3}$

$550 \mathrm{lb} / 10^{6} \mathrm{ft}^{3}$

$1.7 \mathrm{lb} / 10^{6} \mathrm{ft}^{3}$

Plants equipped with flue gas desulfurization (FGD) systems were accounted for by multiplying the values for uncontrolled SO $_{\mathbf{x}}$ emissions by the efficiency values provided by Pechan. Emission reductions due to scrubbers that began operating after 1980 were not included in the data base. Table 2-5 presents a summary of these plants. 25 .

The $\mathrm{NO}_{\mathbf{x}}$ emission factors represent average values that were applied to all boilers, including tangentially-fired, cyclone, 
TABLE 2-5. LIST OF UTILITY FGD UNITS EAST OF THE MISSISSIPPI RIVER STARTING OPERATION AFTER 1980 (AS OF JUNE 1982) 25

\begin{tabular}{|c|c|c|c|c|}
\hline Utility & Unit & $\begin{array}{l}\text { Generating } \\
\text { capacity } \\
\text { MW (gross) }\end{array}$ & $\begin{array}{l}\text { Startup } \\
\text { date } \\
\text { month/yr }\end{array}$ & \\
\hline Cincinnati Gas \& Electric & East Bend 2 & 650 & $3 / 81$ & \\
\hline Hoosier Encrgy & Merom 2 & 490 & 17.81 & \\
\hline Lakeland: & McIntosh & 364 & $1 / 82$ & \\
\hline Louisville Gas \& Electric & Mill Creek 2 & 350 & $12 / 81$ & \\
\hline Niagara Mohawk Power & $\begin{array}{l}\text { Charles } \dot{R} \text {. } \\
\text { Huntley } 66\end{array}$ & 100 & $4 / 82$ & $\begin{array}{l}. \\
\cdot \\
.\end{array}$ \\
\hline Philadelphia Electric & Eddystone 1 & 240 & $5 / 82$ & \\
\hline $\begin{array}{l}\text { South Carolina Public } \\
\text { Service }\end{array}$ & Winyah 4 & 280 & $7 / 81$ & \\
\hline
\end{tabular}


etc., for each fuel, since $\mathrm{NO}_{\mathbf{x}}$ emission factors by boiler type were unavailable at the time these estimates were made. Thus, although the $\mathrm{NO}_{\mathrm{x}}$ emission estimates should be considered preliminary until the more detailed $\mathrm{NO}_{\mathbf{x}}$ data are received, they were considered adequate for this study.

\subsubsection{Residential/Commercial Sector}

The Department of Energy's State 1980 Energy Data Base (SEDB) formed the basis for estimating energy consumption for the residential/commercial sectors. ${ }^{21}$ state data from SEDB were apportioned to the county level, based on 1980 population figures from the Bureau of Census. 26

\section{Fuels Consumed--}

In the residential sector, the major fuels consumed are. natural gas, LPG, distillate oil, and kerosene. 21 For this study, natural gas was grouped with LPG and distillate oil was grouped with kerosene. In the commercial sector, natural gas, LPG, distillate oil, kerosene, and residual oil are the major fuels consumed, and again natural gas was grouped with LPG and distillate oil with kerosene. Small amounts of coal in both the residential and commercial sectors were excluded from the data base.

Table 2-6 presents emission factors for both the residential and commercial sectors. ${ }^{13}$ It was assumed that emission rates for the combustion of LPG are the same on a heat input basis as those for natural gas. The emission rate from the combustion of kerosene was assumed to be the same as that for distillate fuel oil. 
TABLE 2-6. RESIDENTIAL AND COMMERCIAL EMISSION FACTORS ${ }^{13,27}$

\begin{tabular}{l|c|c|c}
\multicolumn{4}{c}{$\left(1 \mathrm{~b} / 10^{6} \mathrm{Btu}\right)$} \\
\hline & $\mathrm{NO}_{\mathrm{x}}$ & $\mathrm{SO}_{\mathrm{x}}$ & $\mathrm{HC}$ \\
\hline Residential & & & \\
Natural gas and LPG & 0.098 & 0.0006 & 0.008 \\
Distillate oil and kerosene & 0.130 & $1.036(\mathrm{~s})^{\mathrm{a}}$ & 0.018 \\
Commercial & & & \\
Natural gas and LPG & & & \\
Distillate oil and kerosene & 0.098 & 0.0006 & 0.008 \\
Residual oil & 0.144 & $1.036(\mathrm{~s})_{\mathrm{a}}^{\mathrm{a}}$ & 0.004 \\
\hline \hline
\end{tabular}

a Were $S$ equals the percent sulfur by weight.

\subsubsection{Transportation Sector}

The Department of Energy's SEDB formed the basis of energy consumption estimates for the transportation sector. The SEDB incorporates energy consumption from the following transportation segments: highway use (73\%), aviation (128), pipeline compressore and pumps (38), and other $(128) .21,28$ The "other" category includes marine use, railroads, and transportation fuels consumed by the armed forces.

The state transportation data are reported by fuel types (natural gas, aviation gasoline, distillate fuel, jet fuel, LPG, motor gasoline, residual fuel). Lubricants are also reported but are not used as fuel. In some cases, the specific uses (i.e., marine use, railroads, etc.) of small amounts of certain fuels cannot always be separated from the reported fuel values; therefore, simplifying assumptions (most of which have little impact on present results) were made. 
Table 2-7 lists the fuels consumed in the transportation sector, their use(s), and the percentage each represents of total transportation fossil fuels consumed. Motor gasoline and distillate fuel, which account for most (778) of the energy consumed in the transportation sector, were the only two fuels analyzed. All consumption was assumed to be in motor vehicles.

The 1980 estimate of energy consumption from transportation fuels was based on the assumption that motor gasoline and distillate fuel consumption (and resulting emissions) were proportional to the number of motor vehicles registered in individual counties. 29

Emission factors for motor gasoline and distillate fuel are as follows: 13,30

\begin{tabular}{c|c|c|c}
\multicolumn{2}{c}{} & \multicolumn{3}{c}{$1 \mathrm{~b} / 10^{6} \mathrm{Btu}$} \\
\cline { 2 - 4 } & $\mathrm{NO}_{\mathbf{x}}$ & $\mathrm{SO}_{\mathbf{x}}$ & $\mathrm{HC}$ \\
\hline Motor gasoline & 0.840 & 0.048 & 0.878 \\
Distillate fuel & 2.432 & 0.236 & 0.388
\end{tabular}

Jet fuel and aviation gasoline were not accounted for. Emissions are normally based on the number of landings and takeoffs rather than on total fuel used. The U.S. EPA method for estimating each county's emissions from these fuels, based on the number of aircraft landings and take-offs, is current to 1980. These data are updated annually. This is considered a satisfactory method for calculating and updating emissions. 31 The 1980 NEDS estimates (total U.S.) for aircraft are 131,000, 16,000, and 234,000 tons/yr for $\mathrm{NO}_{\mathrm{X}^{\prime}} \mathrm{SO}_{\mathrm{X}^{\prime}}$, and $\mathrm{HC}$ respectively. These emissions were not included in the present data base; 
TABLE 2-7. TRANSPORTATION FUEL USES AND PERCENTAGE OF TOTAL FOSSIL FUELL 21,28

\begin{tabular}{|c|c|c|c|}
\hline Fuel type & Uses & $\begin{array}{l}\text { Percentage } \\
\text { total fuel }\end{array}$ & $\begin{array}{l}\text { of } \\
\text { use }\end{array}$ \\
\hline Motor gasoline & $\begin{array}{l}\text { Highway } \\
\text { Marine use }\end{array}$ & $\begin{array}{l}\therefore \quad 63.0 \\
\text { Neg. }\end{array}$ & $\ldots 1$ \\
\hline Distillate fuels & $\begin{array}{l}\text { Highway } \\
\text { Vessel bunkering } \\
\text { Armed forces } \\
\text { Railroads }\end{array}$ & $\begin{array}{l}9.7 \\
4.5 \\
\because \quad 9\end{array}$ & 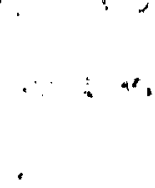 \\
\hline Jet fuel & $\begin{array}{l}\text { Military } \\
\text { Nonmilitary }\end{array}$ & 11.1 & $\therefore$ \\
\hline Aviation gasoline & $\begin{array}{l}\text { Military } \\
\text { Nonmilitary }\end{array}$ & 0.3 & \\
\hline Natural gas & Pipeline compressors and pumps & 3.3. & \\
\hline Residual fuel & $\begin{array}{l}\text { Armed forces (ships) ... } \\
\text { Railroads }\end{array}$ & $\therefore 7.1$ & \\
\hline Lubricants & & 0.9 & \\
\hline LPG & Internal combustion engines & 0.1 & \\
\hline
\end{tabular}


however, they could be added to the existing data base by obtaining the data from NEDS.

Residual oil consumed by railroad trains and vessels and by the military were also excluded from the present estimate. The 1980 NEDS estimates for vessels are $160,000,221,000$, and 463,000 tons/yr for $\mathrm{NO}_{\mathrm{x}^{\prime}} \mathrm{SO}_{\mathrm{x}}$, and $\mathrm{HC}$ respectively. Again, the methodology used by NEDS was judged to be satisfactory for estimating emissions from these sources should a more accurate inventory be needed.

The final fuel excluded from the analysis was pipelined natural gas used in combustors. This fuel was excluded because a methodology was not developed to allocate energy use and emissions to the county level. Although the use of this fuel is small (3.38 of the total in the transportation sector), the resulting $\mathrm{NO}_{\mathrm{x}}$ emissions are substantial (about 500,000 tons/yr, for the entire U.S. based on the SEDB fuel total and the assumption that the fuel use is split evenly between gas turbines and IC engines). "One possible solution to this problem would be to include natural gas from the transportation sector in the industrial sector fuel totals, and distribute the emissions according to the number of manufacturing employees per county. Alternatively, NEDS data could be utilized. The use of natural gas in gas turbines and IC engines is also reported in NEDS under "industrial fuel" rather than in the transportation sector. The 1980 NEDS estimate of total $\mathrm{NO}_{\mathbf{x}}$ emissions in the United States for this category is 763,000 tons. 
2.1.6 Summary Description of Data Base Installed on DOE-METC Computer

The data base that has been installed on the METC computer consists of a set of 8310 records, each pertaining to one of the seven sectors in the study: transportation, commercial, residential, utility, industrial boiler, industrial direct-fired, and industrial area sources. Table 2-8 summarizes the number of records in each sector. There is a single record for each of the 1576 counties in the study area for the transportation, commercial, residential, and industrial area source sectors. Table 2-9 presents a more detailed breakdown of the 956 records in the industrial direct-fired sector.

TABLE 2-8. SUMMARY OF THE DATA BASE BY SECTOR FOR 26 STATES EAST OF THE MISSISSIPPI

\begin{tabular}{l|c}
\hline \multicolumn{1}{c|}{ Sector } & $\begin{array}{c}\text { Number } \\
\text { of records }\end{array}$ \\
\hline Transportation & 1576 \\
Commercial & 1576 \\
Residential & 1576 \\
Utility & 779 \\
Industrial boiler & 271 \\
Industrial direct-fired & 956 \\
Industrial aroa & 1576 \\
\hline \hline
\end{tabular}

Every record in the data base contains fuel and emission data for a single source in the study area. Each record contains identifiers for the state, county, and sector. Each also contains annual fuel consumption (in $10^{9} \mathrm{Btu}$ ) for coal, residual oil, distillate oil, natural gas, motor gasoline, and other solid, liquid, and gaseous fuels, as well as the amount of $\mathrm{so}_{\mathbf{x}}{ }^{\prime}$ NO $_{x}$, and HC (in tons) associated with each fuel. Records for 
TABLE 2-9. INDUSTRIAL DIRECT-FIRED FECORDS FOR 26 STATES EAST OF THE MISSISSIPPI

\begin{tabular}{|c|c|c|}
\hline SIC & Industry & $\begin{array}{c}\text { Number } \\
\text { of plants }\end{array}$ \\
\hline $\begin{array}{l}2611 \\
2819 \\
2819 \\
2819 \\
2861 \\
2861 \\
2865 \\
2865 \\
2869 \\
2869 \\
2873 \\
2873 \\
2895 \\
2911 \\
3211 \\
3221 \\
3229 \\
3241 \\
3252 \\
3274 \\
3275 \\
3295 \\
3296 \\
3296 \\
3312 \\
3312 \\
3312 \\
3321 \\
3331 \\
3334 \\
3339 \\
3341 \\
3341 \\
3341 \\
3353\end{array}$ & $\begin{array}{l}\text { Kraft pulp } \\
\text { Alumina } \\
\text { Lithium carbonate } \\
\text { Titanium dioxide } \\
\text { Ethanol } \\
\text { Methanol } \\
\text { Dimethyl terephthalate } \\
\text { Styrene } \\
\text { BTX } \\
\text { Ethylene/propylene } \\
\text { Ammonia } \\
\text { Sodium phosphate } \\
\text { Carbon black } \\
\text { Petroleum } \\
\text { Flat glass } \\
\text { Container glass } \\
\text { Pressed and blown glass } \\
\text { Cement } \\
\text { Brick and structural clay tile } \\
\text { Lime } \\
\text { Gypsum } \\
\text { Lightweight aggregate } \\
\text { Mineral wool } \\
\text { Fiberglass wool } \\
\text { Coke } \\
\text { Integrated iron and steel } \\
\text { Mini/midi iron and steel } \\
\text { Iron foundries } \\
\text { Primary copper } \\
\text { Primary aluminum } \\
\text { Primary zinc } \\
\text { Secondary aluminum } \\
\text { Secondary copper } \\
\text { Secondary lead } \\
\text { Aluminum fabrication }\end{array}$ & $\begin{array}{r}75 \\
2 \\
2 \\
3 \\
1 \\
1 \\
5 \\
2 \\
1 \\
5 \\
21 \\
8 \\
4 \\
61 \\
21 \\
75 \\
64 \\
64 \\
134 \\
69 \\
20 \\
8 \\
8 \\
15 \\
23 \\
41 \\
41 \\
99 \\
2 \\
12 \\
4 \\
10 \\
6 \\
2 \\
47\end{array}$ \\
\hline
\end{tabular}


point sources (utilities, industrial boilers, and industrial direct-fired plants) contain a facility identification number assigned by PEDCo, and the facility name. Records for industrial direct-fired plants also contain annual production (in tons).

\subsection{METHODOLOGY FOR SELECTION OF WET DEPOSITION MONITORING STATIONS AND DATA ANALYSIS TECHNIQUES}

This section describes the methodology used in 1) selecting wet deposition monitoring stations in the eastern Uiited states, 2) choosing the statistical techniques for analyzing the monitoring data, and 3) ascertaining the strengths and weaknesses of this analysis. Appendix $A$ in Volume I presents background information on the rationale behind studying wet deposition monitoring data from the standpoint of local and regional-source contributions, and on the various data analysis techniques that are generally available for this type of study.

2.2.1 General Approach - Selection of Study Areas

Selection of the three areas in the eastern United States as the focal points for this analysis was based primarily on the availability of wet deposition monitoring data and the emissinn patterne in the areas. Each of these areas has different meteorological conditions and physical features:

- Hudson River Valley, New York-thigh area source emicsions, well-defined transport limits due to the valley, frequent precipitation, strong seasonal pattern of . ... surface wind directions. Area contains three NADP stations and one MAP3S Station essentially co-located with an NADP station. 
Eastern Ohio/western Pennsylvania--High industrial activity, utilities west and south, little fluctuation in monthly prevailing winds in Pennsylvania, monthly variation of prevailing winds in Ohio. Area contains four NADP stations, one EPRI station near an NADP station, and one MAP3S station near an NADP station.

- Tennessee, North Carolina, South Carolina--Generally 、 low emissions with pockets of high emission density counties, well-defined transport limits due to the mountainous terrain, minimal impact by long-range transport suspected. Area contains four NADP stations.

Emission patterns in these areas are discussed further in Section 3.

2.2.2 Evaluation of Existing Wet Deposition Networks for Analysis

Several monitoring networks east of the Mississippi River : . have generated wet deposition data, and these data were evaluated for possible use in this study (see Table 2-10). Given the scope of this study, however, only those networks having the greatest number of stations were singled out for further review: 1) the National Atmospheric Deposition Program (NADP), 2). the Electric Power Research Institute (EPRI), 3) the Multistate Atmospheric Deposition. Power Production Pollution Study (MAP3S), and 4) the Great Lakes Atmospheric Deposition Network (GLAD). Figure 2-4 shows the locations of monitoring stations in these four networks. Because the GLAD network has only been in operation since 1981, it was dropped. from further consideration, as this precluded the documentation of quality assurance/quality control ' $(\mathrm{QA} / \mathrm{QC}) \cdot$ procedures.

As shown in Figure 2-4, each network can provide data upon request; all except GLAD have been generating data for several 
TABLE 2-10. ACID DEPOSITION STATIONS EAST OF THE MISSISSIPPI RIVER

\begin{tabular}{|c|c|c|c|}
\hline Program & $\begin{array}{l}\text { Number of } \\
\text { stations } \\
\text { east of } \\
\text { the Missis- } \\
\text { sippi River }\end{array}$ & $\begin{array}{l}\text { Period of } \\
\text { data }\end{array}$ & $\begin{array}{l}\text { Collection } \\
\text { froquency }\end{array}$ \\
\hline $\begin{array}{l}\text { National Atmospheric } \\
\text { Deposition Program } \\
\text { (NADP) }\end{array}$ & 49 & 1978 to present & Weekly \\
\hline Department of Energy & 4 & Unknown & Unknown \\
\hline $\begin{array}{l}\text { Environmental Protec- } \\
\text { tion Agency/World } \\
\text { Monitoring Organiza- } \\
\text { tion }\end{array}$ & 5 & $1976-1978^{a}$ & Monthly \\
\hline $\begin{array}{l}\text { Multi-State Atmospheric } \\
\text { Power Production Pol- } \\
\text { lution Study (MAP3S) }\end{array}$ & 8 & 1976 to present & Event \\
\hline $\begin{array}{l}\text { Electric Power Research } \\
\text { Institute (EPRI) }\end{array}$ & 9 & 1978 to present & Event \\
\hline $\begin{array}{l}\text { Oak Ridge National } \\
\text { Laboratory }\end{array}$ & 1 & Unknown & Unknown \\
\hline Uiriversity of Floridd & 4 & 1978,1979 & Event/biweekly \\
\hline $\begin{array}{l}\text { Great Lakes Rain Depo- } \\
\text { sition }\end{array}$ & $25^{b}$ & 1981 to present & Weekly \\
\hline
\end{tabular}
a Became part of NADP.
b All located in EPA Region $V$. 


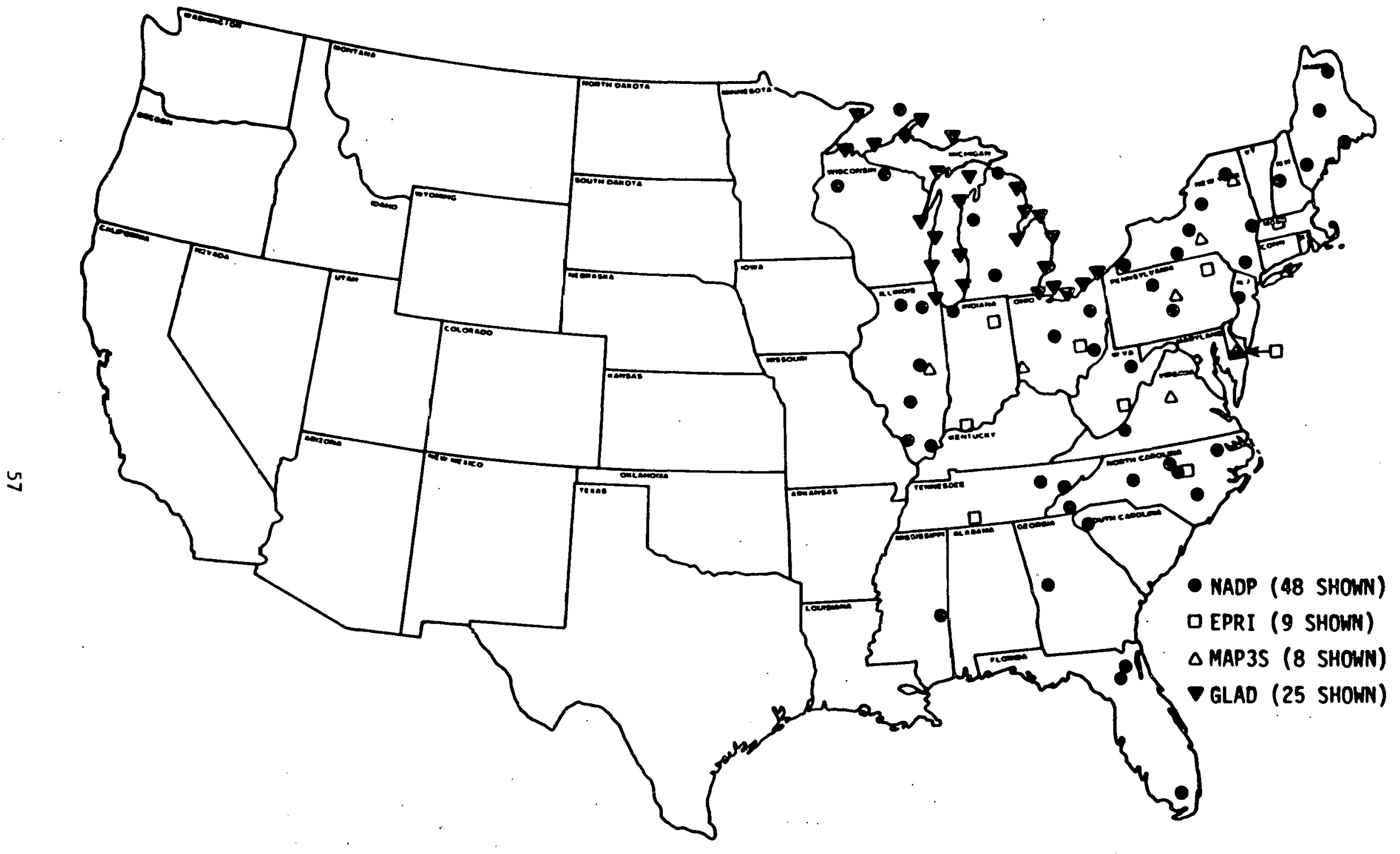

Figure 2-4. Locations of sampling sites within Four Program Networks (East of the Mississippi River sites only). 
years. The amount of data available varies with the startup time of each location. There also is a lag time between sample collection and data release to allow for sample analysis, quality control, data entry, data verification, etc. As of March 1983, both NADP and EPRI data were available through the end of 1980 .

Data from at least three NADP stations are available in each of the three selected study areas. Data from only one EPRI station and two MAP3S stations are availabie, and each of these stations is located near one of the NADP stations with current data. The available NADP data cover weekly. samples for all of the important ionic species ( $\mathrm{pH}$, calcium, magnesium, potassium, sodium, ammonia, nitrate, sulfate, phosphate, and hydrogen ion) on a wet basis only. Data on these same species are also available from EPRI and MAP3S stations on each precipitation event. Each of these three networks uses and documents proper $Q A / Q C$ procedures.

The data from NADP were chosen for analysis because 1) an adequate number of stations was available within the areas of interest, 2) the quantity of data available was sufficient for analysis, and 3) the quality assurance/quality control procedures appeared to be acceptable. Data from the EPRI and MAP3S networks were not unsuitable for analysis, but the NADP network was believed to be the best choice for this.study because of the quantity, quality, and accessibility of the data and the scope of this project. Other advantages in the use of NADP data are: 
- All samples are collected on the same sampling schedule, in sampling apparatus specified. by NADP.

- All sampling sites are subjected to identical sampling and reporting protocol.

- The data are available on magnetic tape, accompanied by a report-form hard copy and $Q A / Q C$ manuals.

- The NADP station that represents the limiting factor for data availability in each study area (i.e., the stations with fewest data points) is not located near a station from another network in any area. Thus, no additional data would actually become available for these sites.

Consideration was not given to adding data from EPRI or MAP3S because such additions would require verification of similar sampling and reporting protocol, combination of event data into a weekly period format, and reformatting of the data into a similar type format. "These tasks were beyond the scope of this effort. Even'a quick, qualitative look at these networks would require selection of data collected during the same time periods as those available in NADP, as all comparisons made in this study represent concurrently collected data points.

\subsubsection{Summary of Data Analysis Methods Applied to This Study}

Two different statistical analysis mcthods wore selected to analyze the temporal and spatial variations in the deposition data at all receptors available within the NADP data base in the three areas of interest. Pearson correlation coefficients were used to determine intersite correlations for various species $\left(\mathrm{NO}_{3}^{-}, \mathrm{SO}_{4}^{-2}, \mathrm{Ca}\right.$, and $\left.\mathrm{Cl}\right)$, which were tested against significant values of $r$. An analysis of the average values and standard 
deviations (analysis of variance, ANOVA) was performed to ascertain similarities in the amount of deposition at each station. Each study area average was tested for significance by use of the $F$ test and significant values of $F$. Station pair means within a study area were compared by testing for significant contrasts by use of the $t$ statistic and separate variances. Comparisons were made with a table of significant values of $t$ :

All conclusions regarding the significance of findings aro based on an a level of 0.10 , or a 90 percent significance level." Because most of the analyses were performed by use of a computerized statistical program, the actual significance levels were output as well, Common a levels for significance tcoting include $0.10,0.05$, and 0.01 , with corresponding significance levels of 90,95 , and 99 percent, respectively. This analysis uses an a level of 0.10 ; this level was selected because of the great variability of the data, the amount of data available for analysis, and investigators are of the opinion that 90 percent is a reasonable confidence level for sound interpretive justification. Actually, many of the results presented later would have tested significant even at a equal to 0.01 ; however, the decision to test at an a of 0.10 was made prior to obtaining the. . statistical results, and only significance stated is that at the. 90 percent confidence level.

\subsubsection{Data Treatment}

The NADP data, which were received in magnetic tape format from the colorado state University in Fort collins, Colorado, 
included all data generated as part of the program between mid1978 and the end of 1980." [More current data (1981) may be available in the near future.] The data were sorted by station (alphabetically by state, then county). The raw tape was first accessed to extract the sampling date, site code, quality assurance information, sample volume, and measured concentration of all species for the states east of the Mississippi River.

The deposition rate for the total sampling period was calculated as: follows:

Deposition rate $\left(\mathrm{mg} / \mathrm{m}^{2} / \mathrm{cm}\right.$ of $\left.\mathrm{ppt}\right)=$ $\frac{\text { measured concentration } x \text { sample volume }}{\text { area of sampler } x \text { depth of precipitation }}$

Deposition rate values were used in the analysis because they are less affected by precipitation volume.

Deletions were made from the sampling dates within each of the analysis areas until the list for analysis included a data point from a particular monitor only if all other monitors in the area also generated data at the same time. If one monitor in an area failed to collect a valid sample, the analysis did not include any monitor's results for that particular week.

Bulk samples (i.e., wet and dry) were missing data. Longduration wet samples (i.e., longer than the one-week sampling period) were split into two samples. If sampling was begun on a day different from sampling at the other stations in the area, the sampling date was modified so that all samples in the area 
are stated as being started on the same day. This modification was necessary most often around the holidays when samples were often collected one day late.

Although other data were used in this analysis, they are not included in the statistical treatment of data. Such additional data include meteorological and climatological records, emission summaries, and physical characteristics of the study areas. These data were used only in the selection of subsets of available data and in the process of drawing conclusions from the statistical analyses.

\subsubsection{Limitations of the Analysis}

The analysis has several limitations concerning the representativeness of the data used and the interpretive capabilities of the results. The most apparent limitation is that of data availability. As discussed earlier, although several networks have been generating data for many years, these data are generally readily available only through 1980 . The NADP network (chosen for analysis of the study areas) consists of elemental and ionic analyses from weekly precipitation samples. A procedure was used to ensure that all observations entering this statistical analysis were based on a comparable time period. Table 2-11 summarizes the observations used in this analysis. Although a reasonable number of total observations were analyzed, the number of points per station is somewhat small, especially for the Tennessee area. This results in the omission 
of some months of the year in the analysis. Often, only one or two observations for certain months are available in the origi-. nal data base.

TABLE 2-11. SUMMARY OF CONCURRENT WEEKLY OBSERVATIONS AVAILABLE IN EACH STUDY AREA

\begin{tabular}{l|c|c|c}
\hline \multicolumn{1}{|c|}{} & $\ldots$ & $\begin{array}{c}\text { Number of } \\
\text { Stations } \\
\text { observations } \\
\text { per station }\end{array}$ & $\begin{array}{c}\text { Total } \\
\text { number of } \\
\text { observations } \\
\text { analyzed }\end{array}$ \\
\hline $\begin{array}{l}\text { New York Hudson River Valley } \\
\text { Ohio/Pennsylvania }\end{array}$ & 3 & 29 & 87 \\
$\begin{array}{l}\text { Tennessee/North Carolina/South } \\
\text { Carolina }\end{array}$ & 4 & 54 & 216 \\
\hline
\end{tabular}

Another limitation of this analysis is that the average deposition rates of each of the three areas are not directly comparable. Although the data from each study" area are comparable, the average deposition rates in each area are derived from a subset of data representing a different time period." Thus, the average deposition rates cannot be compared between areas nor against annual averages.

The availability of meteorological data presents a minor limitation. Surface wind data necessary for adequate characterization of local wind patterns were available from most locations within each area; the exception was the availability of published surface data for extended time periods in the Adirondack area of New York. The availability of upper air data was more limited; at times the characterization of upper air patterns had to be based on average data published by Holzworth. 32 
Another limitation is that analyses could not be conducted for total acid deposition because all of the collection efficiencies of the deposition samplers were not always equal to 100 percent. Because the rain gauge depths required to calculate a total deposition quantity were not available for most of the observations within the data base utilized, total deposition analyses were not performed. For calculations of deposition rates, it was recessary to assume the collection efficiency for any particular observation that was not equal to 100 percent resulted from the actual amount of precipitation entering the sampler rather than to evaporation or other losses of collected precipitation.

Finally, although the statistical techniques used to anaIyze the data are quantitative, the assessment of source contributions is qualitative in nature. Thus, the results can only be used to suggest probable cause and effect relationships.

2.2 .6 strengths of the Analysis

The procedures for performing all of the statistical analyses and the guidance for interpretation of the results were developed before receipt of the magnetic tape containing the raw deposition data for two reasons. First, the tape was known to contain over 15,000 individual data records, and sesond, this minimizes the subjectiveness of data selection. Herein lies one of the major strengths of the analysis. With the exception of minor editing to manipulate the file into a similar format and the analysis required to check for outliers, none of the data selection was subjective. Definitions of all data subsets were 
based on meteorological data or seasons prior to actual receipt of the data. All valid observations were used, which eliminated any concerns regarding biased results.

Another strength lies in the fact that only concurrent observations were analyzed. That each set of observations used was obtained during the same weekly period at each station within the study areas produces consistency within the data. All variations between the observations at the stations are for the same collection periods; thus, the observations are subject to less stray variations than if the number of observations at each station were unequal. Because this ensures that the analysis does not utilize data when one of the stations did not collect a sample, it greatly reduces the chances of introducing a bias due to the inherent differences between time periods. As is shown later in Section 4, the results for sulfates follow a reasonable and consistent trend in each of the three areas. None of the results are very out of line, and most can be explained quite easily. In some cases, the same is true for the nitrate results, although explanation of these results is more difficult because much less background information is available. The results obtained for calcium and chloride verify that there is nothing unusual in the observations used in analyses, as these species also lead to logical but slightly different interpretation. Thus, there appears to be no systematic bias in the data used in the analyses as a result of collection method, analysis methods, station locations, etc. 


\section{REFERENCES FOR SECTION 2}

1. Radian Corporation. Energy Use Patterns and Environmental Implications of Direct-Fired Industrial Processes. Prepared for U.S. Department of Energy, Washington, D.C. DCN 79-230-139-20-03, April 1980 .

2. Battelle Columbus Laboratories. Energy IIse Patterns in Metallurgical and Nonmetallic Mineral Processing. Prepared for the Bureau of Mines, Washington, D.C. 1975.

3. Institute of Gas Technology. Study of Industrial Uses of Energy Relative to Environmental Effects. Prepared for U.S. Environmental Protection Agency, Research Triangle Park, North Carolina. 1974.

4. Institute of Gas Technology. Survey of Emission Control and Combustion Equipment Data in Industrial Process Heating. EPA-600/7-76-002, 1976 .

5. Energy and Environmental Analysis, Inc. The Technical Feasibility of Coal Use in Industrial Heat Applications. Washington, D.C, DOE EJ-78-C-01-2832, 1978.

6. PEDCo Environmental, Inc. Control Techniques for Sulfur Oxide Emissions from Stationary Sources. 1981.

7. PEDCo Environmental, Inc. Review of Energy Consumption in Major Industrial Direct-Fired Processes. Prepared for Department of Energy, Morgantown, West Virginia. 1981.

8. Drexel University. Energy Analysis of 108 Industrial Processes. Prepared for the U.S. Department of Energy under Contract No. E(11-1)1862. Washington, D.C. 1980 .

9. Kirk-Othmer. Encyclopedia of Chemical Technology. Volumes 1-20. 3rd Ed. John Wiley \& Sons, New York. 1980.

10. SRI International. 1982 Directory of Chemical Producers. Menlo Park, California. 1982.

11. U.S. Department of the Interior. Minerals Yearbook Volume 1. Metals and Minerals. Bureau of Mines, Washington, D.C. 1980 . 
12. U.S. Environmental Protection Agency. Industrial Process Profiles for Environmental Use. Chapters 1-29. EPA-600/2$77-023,1977$.

13. U.S. Environmental Protection Agency. Compilation of the Air Pollutant Emission Factors. 3rd Edition, including Supplements 1 through 13. Research Triangle Park, North Carolina. AP-42, 1977.

14. U.S. Environmental Protection Agency. Air Pollution Engineering Manual. Research Triangle Park, North Carolina. AP-40, 1973.

15. U.S. Environmental Protection Agency. Aeros Manual Series. Volume V: Aeros Manual of Codes. Research Triangle Park, North Carolina. EPA-450/2-76-005, 1976.

16. U.S. Environmental Protection Agency. Source Assessment Reports. Contract EPA-68-02-1874.

17. U.S. Environmental Protection Agency. Source Category Survey Reports. EPA-450/3-80-001 and series.

18. Mills, J. L., et al. Emissions of Oxides of Nitrogen from Stationary Sources in Los Angeles County. Report No. 4. Prepared for the Los Angeles County APCD. Los Angeles, California. 1961.

19. PEDCo Environmental, Inc., and Paul W. Spaite Company. Development of an Independent Combustion Source No Inventory and Application to 150 Counties in the Northeastern United States (Draft). Prepared for U.S. Environmental Protection Agency under Contract No. 68-02-3173, Task Order 78. Cincinnati, Ohio. October 1982.

20. U.S. Environmental Protection Agency. AEROS Manual. Volume V. AEROS Manual of Codes. Update Number 4. Research Triangle Park, North Carolina. EPA-450/2-76-005-4, August 1981 .

21. U.S. Department of Energy. State Energy Data Report 1960 through 1980. Washington, D.C. DOE/EIA-0214(80), 1982.

22. U.S. Department of Commerce County and City Data Book, 1977. U.S. Bureau of the Census, Washington, D.C. 1978.

23. E. H. Pechan and Associates, Inc. Estimates of Sulfur Oxide Emissions from the Electric Utility Industry. Prepared for the U.S. Environmental Protection Agency, Washington, D.C. 1982 . 
24. U.S. Department of Energy. Generating Unit Reference File Computer Printout. Generating Plant List in Numeric Order by Plant. Energy Information Administration, Washington, D.C. 1982 .

25. PEDCo Environmental, Inc. EPA Utility FGD Survey. April June, 1982. Volumes I and II. Prepared for U.S. Environmental Protection Agency under Contract 68-02-3173, Washington, D.C. 1982 .

26. U.S. Department of Commerce. 1980 Census of Population and Housing. Bureau of the Census, Washington, D.C. 1981.

27. U.S. Department of Energy. Heating Oils. Washington, D.C. $\mathrm{DOE} / \mathrm{BETC} / \mathrm{PPS}-82 / 4,1982$.

28. Federal Highway Administration. Tables MF-25, MF-26, and Mi-336LA. Highway Statistics Division. Washington, D.C. 1981 .

29. R. L. Polk \& Company. Cars and Trucks in Operation. Prepared for PEDCo Environmental, Inc. Chicago, Illinois. 1981 .

30. PEDCo Environmental, Inc., and Paul w. Spaite Company. Acid Rain: Commentary on Controversial Issues and observations on the Role of Fuel Burning. Prepared for U.S. Department of Energy, under Contract DE-AC21-81MC16361, Morgantown, West Virginia. 1982.

31. U.S. Environmental Protection Agency. NEDS Computer Printout. Area Sources. Research Triangle Park, North Carolina.

32. Holzworth, G. C. Mixing Heights, Wind Speeds, and Potential for Urban Air Pollution Throughout the Contiguous United States. Environmental Protection Agency. Research Triangle Park, North Carolina. AP-101, 1972. 


\section{SECTION 3 \\ DISCUSSION OF INVENTORY ANALYSIS RESULTS}

After the inventory was completed, the data were assembled for assessment of the relative importance of different types of sources within the 26-state study area. County-to-county emission patterns were then studied, and three areas were identified as being representative of distinctly different types of regional emissions: one in which area sources are dominant, one in which industrial sources are dominant, and one rural area in which emissions were expected to be quite low. These regions were later investigated further to determine if relationships existed between emissions and the acidity of precipitation. Finally, estimates for fuel use and emissions from this study were compared with data from independent sources.

\subsection{DISCUSSION OF $\mathrm{NO}_{x}$, SO $\mathrm{x}$, ANU HC EMISSIONS}

3.1.1 Sector Summary Discussion

Summary data for fuel consumption and emissions are shown in Table 3-1. These data confirm the importance of the contribution of utilities in overall emissions of $\mathrm{NO}_{x}$ and $\mathrm{so}_{\mathrm{x}}\left(18.8 \mathrm{x} 10^{6}\right.$ tons/yr); however, they also show that the combined $\mathrm{NO}_{x}$ and $\mathrm{SO}_{x}$ emissions from other sources are also large (e.g., nonutility sources emit $13.5 \times 10^{6}$ tons/yr, industrial sources emit $7.3 \times$ $10^{6}$ tons/yr, and all area sources combined emit $11.4 \times 10^{6}$ tons/yr, 
TABLE 3-1. ANNUAL FUEL CONSUMPTION AND NOx, $\mathrm{SO}_{x}$, AND HC EMISSIONS 3Y SECTOR

\begin{tabular}{|c|c|c|c|c|c|c|c|c|c|c|c|c|}
\hline \multirow[b]{2}{*}{ Sector(s) } & \multirow[b]{2}{*}{$\begin{array}{c}\text { Annual } \\
\text { fuel use, } \\
10^{12} \text { [: }\end{array}$} & \multirow[b]{2}{*}{$\begin{array}{l}\text { Percent } \\
\text { of total } \\
\text { fuel use }\end{array}$} & \multicolumn{7}{|c|}{ Annsal emisstons, tons/yr } & \multirow[b]{2}{*}{$\begin{array}{l}\text { Percent } \\
\text { of total }\end{array}$} & \multirow[b]{2}{*}{$\begin{array}{l}\text { All } \\
\text { pollutants }\end{array}$} & \multirow[b]{2}{*}{$\begin{array}{l}\text { Percent } \\
\text { of total }\end{array}$} \\
\hline & & & ${ }^{\mathrm{NO}} \times$ & \begin{tabular}{|c|}
$\begin{array}{c}\text { Percent } \\
\text { of } \\
\text { total } \\
\mathrm{NO}\end{array}$ \\
\end{tabular} & $\mathrm{SO}_{3}$ & 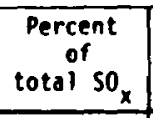 & HC & $\begin{array}{c}\text { Percent } \\
\text { of } \\
\text { total HC }\end{array}$ & $: 50 x+\mathrm{NO}_{x}$ & & & \\
\hline 1 transportation & 8,835 & 24.70 & $4,864,000$ & 42.44 & 348,000 & 1.67 & $3,487,000$ & 96.92 & $5,212,000$ & 16.14 & $8,699,000$ & 24.24 \\
\hline 2 comerctal. & 2,423 & 6.17 & 181,000 & 1.58 & 350,000 & 1.68 & 9,000 & 0.25 & 581,000 & 1.64 & 540,000 & 1.51 \\
\hline 3 residential & 4.650 & 13.00 & 249,006 & 2.17 & 154,000 & 0.74 & 25,000 & 0.70 & 442,000 & 1.25 & 427,000 & 1.19 \\
\hline 4 utflity & 11,275 & 31.52 & $3,896,000$ & 33.99 & $14,912,000$ & 71.59 & 26,000 & 0.13 & $1 E, 597,000$ & 58.24 & $18,833,000$ & 52.48 \\
\hline $\begin{array}{l}\text { Sa Industrial } \\
\text { bollers }\end{array}$ & 1,243 & 3.49 & 380,000 & 3.32 & 927.000 & 4.45 & 12,000 & 0.33 & $1,3[7,000$ & 4.05 & $1,319,000$ & 3.67 \\
\hline $\begin{array}{l}\text { Sb direct-fired } \\
\text { industrial pro- } \\
\text { cesses }\end{array}$ & $1,96]$ & 5.48 & 371,000 & 3.24 & 417.030 & 1.99 & 18,000 & 0.50 & $7 \times 8,000$ & 2.44 & 806,000 & 2.24 \\
\hline $\begin{array}{l}\text { 5c Industrial } \\
\text { area sources }\end{array}$ & 5,379 & 15.03 & $1,521,000$ & 13.21 & $3,723,000$ & 17.79 & 21,000 & 0.58 & $5,245,000$ & 16.24 & $5,265,000$ & 14.67 \\
\hline Total $(1-5 c)$ & 35,768 & 100.00 & $11,462,000$ & 100.00 & $20,830,0<0$ & 100.00 & $3,597,000$ & 100.00 & $32,29: 2,000$ & 100.00 & $35,889,000$ & 100.00 \\
\hline $\begin{array}{l}\text { Convent fonal area } \\
\text { sources }(1,2,3)\end{array}$ & 15.908 & 44.48 & $5.293,000$ & 46.18 & 852,000 & 4.09 & $3,521,000$ & 97.87 & $6,1 \%, 000$ & 19.03 & $9,666,000$ & 26.93 \\
\hline $\begin{array}{l}\text { Resident } 1 \text { al } / c \text { com- } \\
\text { merclal }(2,3)\end{array}$ & 7,074 & 19.78 & 429,000 & 3.75 & 504,000 & 2.42 & 34,000 & 0.95 & $93:, 000$ & 2.89 & 967,000 & 2.70 \\
\hline $\begin{array}{l}\text { Industrial peint } \\
\text { sources }(5 a, 5 b)\end{array}$ & 3,210 & 8.97 & 751,000 & 6.56 & $1,343,000$ & 6.45 & 30,000 & 0.82 & $2,095,000$ & 6.49 & $2,124,000$ & 5.92 \\
\hline $\begin{array}{l}\text { Total Industrial } \\
(5 a, 5 b, 5 c)\end{array}$ & 8,585 & 24.00 & $2,273,000$ & 19.83 & $\$, 060,000$ & 24.32 & 51,000 & 1.41 & $7,139.000$ & 22.73 & $7,390,000$ & 20.59 \\
\hline $\begin{array}{l}\text { Al1 point sources } \\
(4,5 \mathrm{a}, 5 \mathrm{~b})\end{array}$ & 14,485 & 40.50 & $4,547,000$ & 40.54 & $16,255,000$ & 78.04 & 55,800 & 1.55 & $20,900,000$ & 64.73 & $20,958,000$ & 58.40 \\
\hline $\begin{array}{l}\text { All area sources } \\
(I, 2,3,5 \mathrm{c})\end{array}$ & 21,283 & 59.50 & $6,015,000$ & 59.46 & $4,575,000$ & 21.81 & $3,542,000$ & 98.45 & $11,390.000$ & 35.27 & $14,932,000$ & 41.61 \\
\hline $\begin{array}{l}\text { All nonut } 111 \text { ty } \\
\text { sources }(1,2 \text {, } \\
3,5 a, 5 b, 5 c)\end{array}$ & 24,493 & 68.48 & $1,566,000$ & 66.01 & $5.919,000$ & 28.41 & $3,571,000$ & 99.27 & $13,485,000$ & 41.76 & $17,056,000$ & 97.52 \\
\hline
\end{tabular}


including $5.2 \times 10^{6}$ tons/yr for transportation). Most of the emissions from, nonutility sources occur near the ground, which means that localized impacts would be expected if source concentrations are high:

\section{1 .2 NO Emissions}

Table 3-2 presents data for $\mathrm{NO}_{\mathbf{x}}$ emissions by state and sector. These data reflect the importance of $\mathrm{NO}_{x}$ in total combustion emissions $\left(11.5 \times 10^{6}\right.$ tons in 1980 , or 328 of all the combined total for $\mathrm{NO}_{\mathrm{x}^{\prime}} \mathrm{SO}_{\mathrm{x}^{\prime}}$ and HC from combustion). Also illustrated is the contribution of transportation (428), utilities (33\%), and industrial operations $(208)$ in total NO from combustion. These data further show that six heavily populated industrial states in which these three types of activity are prevalent produce almost 50 percent of the total $\mathrm{NO}_{\mathbf{x}}$ from combustion east of the Mississippi River. These states are Pennsylvania (10.98), Ohio (10.58), Illinois (8.08), Indiana (8.08), New York (6.28), and Michigan (6.08). The data also show that total emissions by state are strongly influenced by the degree of industrial development, the population, and the extent of the county area. Hence, the lowest percentages are observed in small, less-developed states such as Vermont (0.28) and Rhode Island (0.38). 3.1.3 so $\mathrm{x}$ Emissions

Table 3-3 presents So $_{\mathrm{x}}$ emissions by state and sector. Sulfur oxides, the dominant combustion emissions being considered, amount to 5.8 percent of the combined total emissions of $\mathrm{NO}_{\mathbf{x}}$, $\mathrm{SO}_{\mathbf{x}}$, and HC. Patterns are similar to those for $\mathrm{NO}_{x}$ in that four of 
TABLE 3-2. SUMMARY OF NO X EMISSIONS BY SECTOR, STATE, AND AS PERCENTAGE OF TOTAL STUDY AREA NO ${ }_{x}$ EMISSIONS

\begin{tabular}{|c|c|c|c|c|c|c|c|c|c|c|}
\hline \multirow[b]{2}{*}{ STATE } & \multicolumn{2}{|c|}{ TRANSPORTATION } & \multicolumn{2}{|c|}{ COMM/RES } & \multicolumn{2}{|c|}{ UTILITY } & \multicolumn{2}{|c|}{ INDUSTRIAL } & \multicolumn{2}{|c|}{ TOTAL } \\
\hline & TONS & 2. & TONS & $z$ & TOHS & 2 & TONS & 2 & TONS & 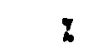 \\
\hline$A_{L}^{\prime}$ & 174878 & 1.33 & 5259 & 0.05 & 176688 & 1.54 & 138146 & 1.21 & 494971 & $4.3 \%$ \\
\hline $\mathrm{Cl}$ & 84136 & 0.73 & 10500 & 0.09 & 24715 & 0.22 & 8017 & 0.07 & $17736 \mathrm{R}$ & 1.11 \\
\hline OE & 21216 & 0.19 & 6371 & 0.06 & |RIT! & 0.16 & 7727 & 0.07 & 53445 & 0.4 \\
\hline$D C$ & 12618 & 0.11 & 1885 & 0.02 & 1798 & 0.02 & 633 & 0.01 & 16934 & 0.15 \\
\hline $\mathrm{Fl}$ & 350935 & 3.06 & 6758 & 0.00 & 208498 & 1.82 & 42416 & 0.37 & 608597 & 5.31 \\
\hline $6 \mathrm{AH}$ & 243390 & 2.12 & 8732 & 0.08 & 192974 & 1.68 & 40274 & 0.35 & 485370 & 4.2 \\
\hline Il & 389715 & 3.40 & 42779 & 0.37 & $32838 t$ & 2.87 & 154758 & 1.35 & 915638 & 7.99 \\
\hline IN & $25494 j$ & 2.22 & 19001 & 0.17 & 304340 & 2.66 & 335608 & 2.93 & 913892 & 7.97 \\
\hline RY & 177325 & 1.55 & .8622 & 0.08 & 220234 & 1.92 & 52442 & 0.46 & 458623 & 4.00 \\
\hline HE & 36892 & 0.32 & 4342 & 0.04 & 4212 & 0.04 & 10551 & 0.09 & 55997 & 0.4 \\
\hline no & 137735 & 1.20 & 11351 & 0.10 & $79 \overline{3} 18$ & 0.69 & 71539 & 0.62 & 299949 & $2.6 ?$ \\
\hline MA & $.14739 !$ & 1.29 & 25077 & 0.22 & 60524 & 0.53 & 7367 & 0.06 & 240359 & 2.1 \\
\hline HI & $27882 j$ & 2.45 & 35180 & 0.31 & 218456 & 1.91 & 150665 & 1.37 & 689124 & 6.01 \\
\hline M5 & 101106 & 0.89 & 7393 & 0.06 & -59684 & 0.52 & 18374 & 0.16 & 186557 & $1: 6$ \\
\hline NH & 25236 & 0.22 & 2894 & 0.03 & 14674 & 0.13 & 1556 & 0.01 & 44360 & 0.3 \\
\hline $\mathrm{NJ}$ & 231748 & 2.02 & 35724 & 0.31 & $6279 \%$ & 0.55 & 33019 & 0.29 & 363893 & 3.1 \\
\hline $\mathrm{HY}$ & $j 49201$ & 3.04 & $7575 z$ & 0.06 & 166212 & 1.45 & 121353 & 1.06 & 711521 & 0.2 \\
\hline NC & $21872 i$ & 1.91 & 8575 & 0.07 & 216389 & 1.89 & 41874 & 0.37 & 485565 & 4.2 \\
\hline $\mathrm{OH}$ & 416001 & 3.63 & 33798 & 0.29 & 140657 & 3.84 & $3111 ! 4$ & 2.71 & 1201570 & 10.48 \\
\hline$P A$ & 3880108 & 3.39 & 36435 & 0.32 & 405828 & 3.54 & 416799 & 3.64 & 1247070 & 10.8 \\
\hline RI & 23181 & 0.20 & 2794 & 0.02 & 2304 & 0.02 & 1307. & 0.01 & 29646 & 0.2 \\
\hline SC & 121025 & 1.06 & 3775 & 0.03 & 75852 & 0.65 & 42431 & 0.37 & 243093 & 2.1 \\
\hline IN & 213148 & $1.8 \dot{t}$ & 5769 & 0.05 & 195877 & 1.71 & $557: 0^{\circ}$ & 0.49 & 470504 & 4.10 \\
\hline VT & 17236 & 0.15 & 1705 & 0.01 & 219 & 0.00 & 687 & 0.01 & 19847 & 0.1 \\
\hline VA & 207844 & 1.81 & 9509 & 0.08 & 67989 & 0.59 & 63936 & 0.56 & 349278 & 3.05 \\
\hline$n:$ & 76546 & 0.67 & $4300^{\circ}$ & 0.04 & 257290 & 2.24 & 88196 & 0.77 & 426328 & $3: 7$ \\
\hline$n$ & $\operatorname{lthin} 4$ & 1.45 & 15067 & 0.13 & 91549 & 0.80 & 49544 & 0.43 & 322264 & 2.8 \\
\hline iotal & 4804108 & 42.44 & 429362 & 3.75 & 3995660 & 33.99 & 2272623 & 19.83 & 11461753 & 100.0 \\
\hline
\end{tabular}


TABLE 3-3. SUMMARY OF SO EMISSIONS BY SECTOR, STATE,

AND AS A PERCENTAGE OF TOTAL STUDY AREA $\mathrm{SO}_{x}$ EMISSIONS

\begin{tabular}{|c|c|c|c|c|c|c|c|c|c|c|c|}
\hline \multirow[b]{2}{*}{ STATE } & & \multicolumn{2}{|c|}{ TRAKSPORTATION } & \multicolumn{2}{|c|}{ COMM/RES } & \multicolumn{2}{|c|}{ UTILITY } & \multicolumn{2}{|c|}{ INDUSTRIAL } & \multicolumn{2}{|c|}{ TOTAL } \\
\hline & & TOHS & $x$ & TONS & 2 & TONS & 2 & TONS & 8 & TONS & $x$ \\
\hline AL & & 13105 & 0.06 & 517 & 0.00 & 609229 & 2.92 & 258692 & 1.24 & 881543 & 4.23 \\
\hline$C T$ & & 5535 & 0.03 & 16959 & 0.08 & 31835 & 0.15 & 35618 & 0.17 & 89947 & 0.43 \\
\hline DE & & 1484. & 0.01 & 21635 & 0.10 & 60436 & 0.29 & 15315 & 0.07 & 98970 & 0.47 \\
\hline$D C$ & & 885 & 0.00 & 1118 & 0.01 & 4565 & 0.02 & 1348 & 0.01 & 7917 & 0.04 \\
\hline$F !$ & : & 24503 & 0.12 & 11799 & 0.06 & 739362 & 3.55 & 119546 & 0.57 & 895270 & 4.30 \\
\hline GA & & 17885 & 0.09 & 681 & 0.00 & 754892 & 3.62 & 57027 & 0.27 & 830485 & 3.99 \\
\hline II & & $28 i 11:$ & 0.14 & 15903 & 0.08 & 1175151 & 5.64 & 256881 & 1.23 & 1476546 & 7.09 \\
\hline IN & & 19523 & 0.09 & 16356 & 0.08 & 1581919 & 7.59 & 926233 & 4.45 & 2544031 & 12.21 \\
\hline KY & & 13738 & 0.07 & $3742^{\circ}$ & 0.02 & 1037551 & 4.98 & 124239 & 0.60 & 1179270 & 5.66 \\
\hline ME & & 2554 & 0.01 & 9135 & 0.04 & 16427 & 0.08 & 29940 & 0.14 & 58056 & 0.28 \\
\hline no & & 9515 & 0.05 & 14060 & 0.07 & 228315 & 1.10 & 123456 & 0.59 & 375346 & 1.80 \\
\hline KA & & 9798 & 0.05 & 43909 & 0.21 & 278348 & 1.34 & 16440 & 0.08 & 348495 & 1.67 \\
\hline II & & 18669 & 0.09 & 9926 & 0.05 & 578275 & 2.78 & 222111 & 1.07 & 828981 & 3.98 \\
\hline nS & & 7470 & 0.04 & 22010 & 0.11 & 131987 & 0.63 & 17984 & 0.09 & 179451 & 0.86 \\
\hline HH & & 1637 & 0.01 & 5077 & 0.02 & 81794 & 0.39 & 5330 & 0.03 & 93838 & 0.45 \\
\hline HJ & & 16123 & 0.08 & 74598 & 0.36 & 105262 & 0.51 & 95865 & 0.16 & 291848 & 1.40 \\
\hline Nr & & $22 i 9 i$ & 0.11 & 156903 & 0.75 & 186774 & 2.34 & 288057 & 1.38 & 954531 & 4.58 \\
\hline NC & & 15517 & 0.07 & 9852 & 0.05 & 145366 & 2.14 & 83056 & 0.40 & 553791 & 2.66 \\
\hline $\mathrm{OH}$ & & 30681 & 0.15 & 9526 & 0.05 & 2273092 & 10.91 & 813214 & 3.90 & 3126513 & $15.0 !$ \\
\hline$P_{\hat{H}}$ & & 28233 & 0.14 & 32057 & 0.15 & 1506781 & 7.23 & 975069 & 4.68 & 2542140 & 12.20 \\
\hline RI & & 1514 & 0.01 & 3558 & 0.02 & 5224 & 0. & 3711 & 0.02 & 14007 & 0.07 \\
\hline SC & & 8649 & 0.04 & 2107 & 0.01 & 217344 & 1. & 76479 & 0.37 & 304579 & 1.46 \\
\hline IN & & 15884 & 0.68 & $1419^{\circ}$ & 0.01 & 957601 & 4.1 & 129942 & & 1104846 & 5.30 \\
\hline VT & & 1197 & 0.01 & 3199 & 0.02 & 380 & 0. & 1726 & 0.01 & 6502 & 0.03 \\
\hline VA & & 15037 & 0.07 & 9249 & 0.04 & 165082 & 0.7 & 84208 & 0.40 & 273660 & 1.31 \\
\hline$w$ & & 5742 & 0.03 & 1270 & 0.01 & 969028 & 4.65 & 216696 & 1.04 & 1192736 & 5.75 \\
\hline \multirow[t]{2}{*}{ II } & & 11904 & 0.00 & 7404 & 0.04 & 469642 & 2.25 & 88138 & 0.42 & 577088 & 2.77 \\
\hline & & & & & & & & & & & \\
\hline OTAL & & 348251 & 1.67 & 503969 & 2.42 & 14911662 & 71.59 & $506641 !$ & 24.32 & 20830293 & 100.00 \\
\hline
\end{tabular}


the six states producing the greatest amount of $\mathrm{NO}_{\mathbf{x}}$ are also highest producers of so $_{x}$; they are ohio (15.08), Indiana (12.28), Pennsylvania $(12.28)$, and Illinois $(7.18)$. Other states producing over 5 percent of the $\mathrm{SO}_{\mathrm{x}}$ east of the Mississippi River are Kentucky, Tennessee, and West Virginia. The data also show that the utility and industrial sectors produce most of the $\mathrm{SO}_{\mathbf{x}}$ in the study area, 71.6 and 24.3 percent, respectively. The states generating the most $\mathrm{SO}_{\mathrm{x}}$ are also high in coal production and use, and the data primarily reflect the use of coal in these sectors. The states with the lowest so $_{\mathbf{x}}$ generation are the same as those lowest in $\mathrm{NO}_{x}$ (Rhode Island and Vermont, both of which produce less than 0.1 percent of the total). Again, this reflects their small size and the more general use of low-sulfur fuels in the northeastern United States.

\section{1 .4 HC Emissions}

The HC emissions (Table 3-4) in the study area are estimated to be $3.6 \times 10^{6}$ tons. This amount represents only 10 percent of the total $\mathrm{NO}_{x^{\prime}} \mathrm{SO}_{x^{\prime}}$ and $\mathrm{HC}$ produced by combustion. Further comparison of $\mathrm{NO}_{x}, \mathrm{SO}_{x}$, and $\mathrm{HC}$ from combustion with total national emissions of these pollutants (presented later) shows that HC from noncombustion sources accounts for 65 percent of the national total. Thus, on an overall basis, HC emissions are not of great importance either in total national emissions or as a part of combustion emissions. In the study area, however, more than 95 percent of the HC from combustion come from the transportation sector, primarily from motor vehicles. As is demonstrated later, 
TABLE 3-4. SUMMARY OF HC EMISSIONS BY SECTOR, STATE, AND AS PERCENTAGE OF TOTAL STUDY AREA HC EMISSIONS

\begin{tabular}{|c|c|c|c|c|c|c|c|c|c|c|}
\hline \multirow[b]{3}{*}{ STATE } & \multirow{2}{*}{\multicolumn{2}{|c|}{ TRANSPORTATION }} & \multicolumn{2}{|c|}{ COHN/RES } & \multicolumn{2}{|c|}{ UTILITY } & \multicolumn{2}{|c|}{ INDUSTRIAL } & \multicolumn{2}{|c|}{ TOTAL } \\
\hline & & & $\cdots$ & $-\cdots$ & $\cdots$ & $-\cdots$ & $\cdots$ & $-\infty-\infty$ & $\cdots$ & \\
\hline & Tous & $x$ & TONS & 2 & TONS & $z$ & rons & 2 & TONS & $y$ \\
\hline$A L$ & 112601 & 3.13 & 412 & 0.01 & 985 & $0.0 j$ & 3577 & 0.10 & 117575 & 3.27 \\
\hline $\mathrm{Cl}$ & 71004 & 1.97 & 1014 & 0.03 & 470 & 0.01 & 709 & 0.02 & 73197 & 2.05 \\
\hline$D E$ & 15972 & 0.44 & 273 & 0.01 & 190 & 0.01 & 270 & 0.01 & 16705 & 0.46 \\
\hline $\mathrm{DC}$ & 9427 & 0.26 & 154 & 0.00 & 34 & 0.00 & 34 & 0.00 & 9649 & 0.27 \\
\hline $\mathrm{FL}$ & 263922 & 7.34 & 441 & 0.01 & 2181 & 0.06 & 4285 & 0.12 & 270829 & 7.53 \\
\hline 6A & 164379 & 4.57 & 698 & 0.02 & 1082 & 0.03 & 1993 & 0.06 & 168152 & 4.67 \\
\hline IL & 263733 & 7.33 & 3334 & 0.09 & 1963 & 0.05 & 4111 & 0.11 & 273141 & 7.59 \\
\hline IN & 154849 & 4.30 & 1452 & 0.04 & 1697 & 0.05 & 5833 & 0.16 & 163831 & 4.55 \\
\hline ky & 104413 & 2.90 & 683 & 0.02 & 1223 & 0.03 & $1150^{\circ}$ & 0.03 & 107475 & 2.99 \\
\hline ME :- & $2934 s$ & 0.79 & 418 & 0.01 & 80 & 0.00 & 921 & 0.03 & 29765 & 0.83 \\
\hline n: & 105308 & 2.96 & 995 & 0.03 & 578 & 0.02 & 1473 & 0.04 & 109354 & 3.04 \\
\hline$M A$ & 122126 & 3.39 & 2056 & 0.06 & 1045 & 0.03 & 427 & 0.01 & 125665 & 3.49 \\
\hline HI & 228095 & 6.34 & 2982 & 0.08 & 1354 & 0.04 & 2515 & 0.07 & 234946 & 6.53 \\
\hline RS & 67401 & 1.87 & 398 & 0.01 & 345 & 0.01 & 578 & 0.02 & 68722 & 1.91 \\
\hline HH & 21823 & 0.61 & 270 & 0.01 & 149 & 0.00 & 82 & 0.00 & 22324 & 0.62 \\
\hline NJ & $1763 t ?$ & 4.90 & 2540 & 0.07 & 536 & 0.01 & 2162 & 0.06 & 181600 & 5.05 \\
\hline $\mathrm{Ni}$ & 296259 & 8.24 & 5102 & 0.14 & 1836 & 0.05 & 2384 & 0.07 & 305581 & 8.49 \\
\hline MC & 160037 & 4.45 & 816 & 0.02 & 1211 & 0.03 & 1378 & 0.04 & 163442 & 4.54 \\
\hline $\mathrm{OH}$ & 279455 & 7.74 & 2844 & 0.08 & 2476 & 0.07 & 4725 & 0.13 & 288500 & 8.02 \\
\hline$P A$ & 268224 & 7.46 & 3383 & 0.09 & 2549 & 0.07 & 6705 & 0.19 & 280880 & 7.81 \\
\hline R! & 19809 & 0.55 & 274 & 0.01 & 37 & 0.00 & 84 & 0.00 & 20204 & $0.5 t$ \\
\hline SC & 87134 & 2.42 & 349 & 0.01 & 457 & 0.01 & 1348 & 0.04 & 89288 & 2.48 \\
\hline IN & 138905 & $3.80^{\circ}$ & 438 & 0.01 & 1092 & 0.03 & 1373 & 0.04 & 141869 & 3.94 \\
\hline VT & 13136 & 0.37 & 159 & 0.00 & 1 & 0.00 & 39 & 0.00 & 13335 & 0.37 \\
\hline VÁ & 145720 & 4.05 & 882 & 0.02 & 611 & 0.02 & 974 & 0.03 & $14818 ?$ & 4.12 \\
\hline$W$ & 49245 & 1.37 & 371 & 0.01 & 1439 & 0.04 & 629 & 0.02 & 51694 & 1.44 \\
\hline \multirow[t]{2}{*}{ NI } & 118857 & 3.30 & 1356 & 0.04 & 503 & 0.01 & 857 & 0.02 & 121553 & 3.38 \\
\hline & - n- & '--- & $\cdots$ & ---- & $-\infty$ & - - & -....- & 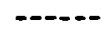 & - & -+- \\
\hline TOTAL & 3486583 & 96.92 & 34104 & 0.95 & 26124 & 0.73 & 50622 & 1.41 & 3597433 & 100.00 \\
\hline
\end{tabular}


in densely populated areas with high motor vehicle usage, the HC emission densities can be quite high in individual counties or in regions such as the New York metropolitan area.

\subsection{SECTOR EMISSION SUMMARIES}

In the five sectors, total emissions vary from an estimated $1.0 \mathrm{million}$ tons/yr for the $\mathrm{NO}_{x}, \mathrm{SO}_{x}$, and $\mathrm{HC}$ from the combined residential and commercial sectors* to $18.8 \mathrm{million}$ tons/yr from utilities. Because some utilities emit pollutants through tall stacks and utilities in general tend to be scattered about the study area, as opposed to other sectors, which emit at lower levels and tend to cluster in various regions, defining the impact of emissions from utilities versus those from other sectors in a given area can be difficult. Thus, total emissions can be misleading. Nevertheless, they are presented hore along with other materials describing the various sectors.

Conversion of total emissions by county to emission densities provides a better measure of the intensity of emissions. Table 3-5 shows the two counties with highest densities in each pollutant-sector category. These data show the variability in densities and also illustrate the weakness of density as a measure of the severity of emissions. Counties with very small areas (such as New York County. New York). show very high densi-

\footnotetext{
The residential and commercial sectors have the following in common: the types of fuel used (mostly oil and natural gas), the nature of the sources (all area sources), and the character of fuel uses (space heat, water heat, etc.). Emission density patterns from the two sectors are also very similar. Hence, - for this analysis, they have been combined.
} 
ties that are representative of small amounts of fuel. On the other hand, very large counties may show low densities even though some part of the county actually has a high concentration of emissions. Although both total emissions and emission densities can be misleading, especially at the county level, no better way was found to express emission distributions.

TABLE 3-5. FIRST AND SECOND HIGHEST EMISSION DENSITY COUNTIES FOR EACH SECTOR IN THE EASTERN UNITED STATES

\begin{tabular}{|c|c|c|c|}
\hline \multirow[b]{2}{*}{ Sector } & \multicolumn{3}{|c|}{ Emission density, tons $/ \mathrm{mi}^{2}$ per $y r$} \\
\hline & $\mathrm{NO}_{x}$ & $\mathrm{SO}_{x}$ & $\mathrm{HC}$ \\
\hline $\begin{array}{l}\text { Residential/ } \\
\text { commercial }\end{array}$ & $\begin{array}{l}268 \text { N.Y. Co., N.Y. } \\
138 \text { Kings, N.Y. }\end{array}$ & $\begin{array}{l}555 \text { N.Y. Co., N.Y: } \\
285 \text { Kings; N.Y. }\end{array}$ & $\begin{array}{l}18 \text { N.Y. Co., N.Y. } \\
9 \text { Kings, N.Y. }\end{array}$ \\
\hline $\begin{array}{l}\text { Transporta- } \\
\text { tion }\end{array}$ & $\begin{array}{l}374 \text { N.Y. Co., N.Y. } \\
275 \text { Phila., Pa. }\end{array}$ & $\begin{array}{l}24 \text { N.Y. Co., N.Y. } \\
20 \text { Phila. Co., Pa. }\end{array}$ & $\begin{array}{l}318 \text { N.Y. Co., N.Y. } \\
218 \text { Kings, N.Y. }\end{array}$ \\
\hline Utility & $\begin{array}{l}415 \text { N.Y. Co. , N.Y. } \\
323 \text { Hudson, N.J. }\end{array}$ & $\begin{array}{l}1357 \text { Gallia, Ohio } \\
1081 \text { Marshail, W. Va. }\end{array}$ & $\begin{array}{l}5 \text { N.Y. Co., N.Y. } \\
3 \text { Queens, N.Y. }\end{array}$ \\
\hline Industrial & $\begin{array}{l}1194 \text { N.Y. Co., N.Y. } \\
499 \text { Phila., Pa. }\end{array}$ & $\begin{array}{l}2944 \text { N.Y. Co., N.Y. } \\
1214 \text { Phila., Pa. }\end{array}$ & $\begin{array}{l}25 \text { N.Y. Co., N.Y. } \\
6 \text { Lake, Ind. }\end{array}$ \\
\hline
\end{tabular}

3.2.1 Commercial/Residential Sectors

Total annual fuel consumption in the combined sectors was $7073.5 \times 10^{12}$ Btu of natural gas, residual oil, and distillate oil, which accounted for 19.8 percent of the total fuel consumed in the study area (Table 3-1). The commercial/residential sectors, however, account for only 4 percent of the NO ${ }_{x}, 2.5$ percent of the $\mathrm{SO}_{x}$, and 1 percent of the HC emissions in the study area.

Fuel is used mainly for space heat, water heat, and other. familiar types of combustion in residences and in offices, stores, and other types of buildings used for commercial activities. The 
amount of fuel used in these activities in a given region is generally related to population density. This fuel use is also generally related to emissions from the transportation sector (mainly from motor vehicles), which also tend to be population related.

The emission densities for the residential/commercial sectors range from less than 1 ton/mi2/yr to 268,555 , and 18 tons/ $\mathrm{mi}^{2} / \mathrm{yr}$ for $\mathrm{NO}_{\mathrm{x}}, \mathrm{SO}_{\mathrm{x}}$, and $\mathrm{HC}$, respectively. These data indicate that although overall emissions in these sectors are low, in areas of hiqh population densities they can be an important source.

\subsubsection{Transportation Sector}

The transportation sector, which consumed $8834.9 \times 10^{12}$ Btu of motor gasoline and distillate fuel, accounted for 24.7 percent of the total annual fuel use in the study area (Table 3-1). Over 40 percent of the study area $\mathrm{NO}_{x}$ emissions, 1.7 percent of the SO ${ }_{x}$ emissions, and 97 percent of the HC emissions are attributed to the transportation sector (Table 3-1).

Transportation fuels that were considered in this study are those used primarily in automobiles and trucks. Fuel use by county was computed by using motor vehicle registrations; however, because emission density levels tend to reflect population densities, they tend to vary with the residential/commercial sector emissions.

The transportation emission densities (Table 3-5) of 374, 24, and 318 tons $/ \mathrm{mi}^{2}$ per year for $\mathrm{NO}_{\mathbf{x}^{\prime}} \mathrm{SO}_{\mathbf{x}^{\prime}}$ and $\mathrm{HC}$, respectively, in this sector as in the residential and commercial sectors, can be quite significant in areas with high-population density: 
These data, along with those for residential and commercial sectors, show that area sources are the dominant source of pollution in some regions. These data also suggest that HC emissions, which are relatively unimportant in most regions, may be important in highly populated areas.

\subsubsection{Utility Sector}

The utility sector consumed $11,274 \times 10^{12}$ Btu of the fuel 1778 coal; 188 residual oil, and 58 natural gas) burned in steam boilers, gas turbines, and internal combustion engines. This amounts to 31.5 percent of the fuel burned in the study area (Table 3-1). Utilities generated 34.0 percent of the $\mathrm{NO}_{\mathrm{x}}, 71.6$ percent of the $\mathrm{SO}_{x^{\prime}}$, and 0.7 percent of the $\mathrm{HC}$ emissions in the study area (Table 3-1).

The study area contained 779 plants that were located in every state except Vermont. Utility fuel consumption and emissions generated do not follow the same patterns observed with the residential, commercial, and industrial sectors. The plants constitute large point sources, which tend to be located near sources of fuel and cooling water. Emissions are not a function of population density. As illustrated by the data in Table 3-5, these large sources tend to dominate the emission density results for $\mathrm{NO}_{\mathrm{x}}$ and $\mathrm{SO}_{\mathrm{x}}$ in counties where they are located. The two counties with the highest density both contain two power plants (the Gavin and Kyger Creek plants in Gallia County, Ohio, and the Kammer and Mitchell plants in Marshall County, West Virginia). These plants account for essentially all of the $\mathrm{so}_{\mathbf{x}}$ produced in these counties. 


\subsubsection{Industrial Sector}

The industrial sector consumed $8584.7 \times 10^{12}$ Btu of fuel, and accounted for 24 percent of total annual fuel consumption in the study area (Table 3-1). Distribution of this fuel consumption is as follows: 31 percent coal, 19 percent oil, 38 percent natural gas, and 11 percent other fuels. An estimated 19.8 percent $(2.3$ million tons per $\mathrm{yr})$ of the $\mathrm{NO}_{\mathrm{x}}$ emissions, 24.3 percent $\left(5.1\right.$ million tons/yr) of the $\mathrm{so}_{\mathrm{x}}$ emissions, and 1.4 percent $(50,622$ tons/Yr) of the HC emissions in the study area were generated by the industrial sector (Table 3-1). The $\mathrm{NO}_{x}$ and So $_{x}$ emissions were divided between industrial boilers (17.8\%), direct-fired industrial processes $(10.8 \%)$, and industrial area sources $(71.48)$.

Density values for the industrial sector (shown in Table 3-5) were obtained by using the number of manufacturing establishments in the counties to distribute the fuel used in industrial area sources. Because area sources consume more than two-thirds of the fuel overall, errors in this assumption can have a great impact on emission and emission density values. This methodology is believed to have resulted in considerable overstatement of the emissions in New York County, New York, and Philadelphia County, Pennsylvania. This can be illustrated by comparing these counties with highly industrialized but much. larger Allegheny County; Pennsylvania, which has emission densities of 84,165 , and 2 tons/ $\mathrm{mi}^{2} / \mathrm{yr}$ for $\mathrm{NO}_{\mathrm{x}^{\prime}}$. $\mathrm{SO}_{\mathrm{x}^{\prime}}$ and $\mathrm{HC}$, respectively. This is discussed further in the industrial area source discussion. 


\section{Industrial Boilers--}

Each of the 271 large boiler facilities in the study area has one or more boilers with a capacity of at least $250 \times 10^{6}$ Btu/yr. Table 3-6 summarizes the calculations of industrial boiler energy and emissions.

The following is a breakdown of total energy consumption in the industrial boiler sector by principal fuel type:

Fuel

Coal

Residual oil

Distillate oil

Natural gas

Process gas

Wood

Bagasse

Other

$$
\begin{gathered}
\text { Quantity, } \\
10^{12} \mathrm{Btu} / \mathrm{yr}
\end{gathered}
$$

410

331

17

216

159

89

16

$\frac{12}{1250}$
Percent of total

$\begin{array}{r}33 \\ 27 \\ 1 \\ 17 \\ 13 \\ 7 \\ 1 \\ 1 \\ \hline 100\end{array}$

of particular interest is the contribution of process gas (refinery gas, blast furnace gas, coke oven gas, etc.l, wood, bagasse, and other. Together these fuels account for more than 20 percent of the total energy consumption in this sector.

There is a marked geographical concentration of these large industrial boiler facilities. Nearly one-half of the total fuel is consumed in five states: Indiana, Florida, Ohio, New York, and Alabama. This geographical concentration is even more striking at the county level. About one-quarter of the total industrial boiler fuel consumption can be accounted for by the following 10 counties:

County

Lake; Indiana Monroe, New York Hancock, West Virginia

Quantity, $10^{12} \mathrm{Btu} / \mathrm{yr}$


TABLE 3-6. SUMMARY BY STATE OF LARGE INDUSTRIAL BOILER FUEL USE AND $\mathrm{NO}_{x}, \mathrm{SO}_{x}$, AND HC EMISSIONS FOR COUNTIES EAST OF THE MISSISSIPPI RIVER

\begin{tabular}{|c|c|c|c|c|c|c|c|c|c|c|c|c|c|}
\hline \multirow[b]{2}{*}{ Sente } & \multirow{2}{*}{$\begin{array}{l}\text { no. of } \\
\text { Focil- } \\
\text { itiles }\end{array}$} & \multicolumn{9}{|c|}{ Fuel Consuption, Bllition Beviyear } & \multicolumn{3}{|c|}{ Enisstons, Tons/rear } \\
\hline & & $\cos 1$ & $\begin{array}{l}\text { kestdual } \\
\text { ofl }\end{array}$ & $\begin{array}{l}\text { urstil- } \\
\text { lete ofl }\end{array}$ & $\begin{array}{l}\text { Watura } \\
\text { gas }\end{array}$ & $\begin{array}{l}\text { Process } \\
\text { gas }\end{array}$ & Nood & Pagasse & other & Total & $\omega_{x}$ & sor & $\mathbf{m}$ \\
\hline Alabana & 20 & 31.531 & 16,681 & 287 & 21.784 & 16,509 & 16.251 & & & 103,144 & 27.214 & 60,950 & 1.790 \\
\hline connect tcut & $\mathbf{3}$ & & 3,660 & & & $\cdot$ & & & & 3,560 & $\mathbf{B 1 7}$ & 2,750 & 13 \\
\hline onleware & 3 & & 1,621 & 99: & 1.159 & & & & & 2,385 & 682 & 1,235 & 1 \\
\hline Dist. of Columbla & o & & & & & & & & & & $\mathbf{0}$ & & 0 \\
\hline Flortda & 18 & 559 & 39,628 & & 25,813 & & 22,908 & 16,292 & 10,964 & $\lfloor 16,163$ & 19,813 & 41,891 & 3.112 \\
\hline Ceorgite & 13 & 4,550 & 27,325 & 383 & 14,584 & & 13,500 & & & 60.342 & 13.218 & 34,072 & 1.250 \\
\hline IIIInois & 15 & 21 B21 & 11,894 & 3 & 21,951 & 3,447 & & & & 59,116 & 18.439 & 39,000 & 105 \\
\hline Indians & 16 & 31,912 & 15,508 & 103: & 18,310 & 71.085 & & & & 136,918 & 40,120 & 93.145 & 46 \\
\hline Kentucky & 9 & 5,791 & 838 & & 9,038 & 5,300 & & & & 21,047 & 6.028 & 12,003 & $n$ \\
\hline Maine & 11 & & 33,894 & & & & 8,529 & & & 42,123 & 8.775 & 25,536 & 84 \\
\hline Narylend & 3 & 6.565 & 1,859 & 435 & 733 & & & & & 9,591 & 5,501 & 9,846 & $\mathbf{u}$ \\
\hline Russacmusetts & 2 & & 493 & & 1,430 & & & & & 1,923 & 494 & 371 & 3 \\
\hline Michigan & 14 & 33,395 & 5,885 & 6. & 37.700 & 1.537 & 1.154 & & & 79,584 & 28.789 & 38,605 & 235 \\
\hline Wississippl. & 6 & & 3,368 & 1.535 & 12,160 & & & & & 17.063 & 4.128 & 3,623 & 23 \\
\hline New Mnopshtre & 1 & & 1,992 & & & & & & & 1,992 & 445 & 1.497 & 7 \\
\hline mew Jersey & 12 & & 16,609 & 506 & 7,856 & & & & & 24,971 & 5.855 & 12,544 & 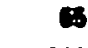 \\
\hline Men rort & 17 & 40,260 & 47,975 & 4,845 & 10,092 & & & & 。 & 103,171 & 35.772 & 94,413 & 20 \\
\hline Morth Caroline & 12 & 15.150 & 26,357 & 9 & 3,946 & & 7,180 & & & 52,543 & 16.056 & 38,500 & 50 \\
\hline Onto & 21 & 56,586 & 0,163 & 3,170 & 9,217 & 31.746 & 345 & & 52 & 109,578 & 4.000 & 124,202 & $m$ \\
\hline Pennsyivanis & 19 & 39.107 & 19,839 & & 1,822 & 9,493 & & & 677 & 71,188 & 24,569 & $\infty, 800$ & 174 \\
\hline mode Island & 2 & & 528 & $:$ & & & & & & 528 & 1118 & 397 & 2 \\
\hline sonth Carolias & 11 & $16 \$ 536$ & 14,136 & 20 & 2,800 & & 7.746 & & & 41,337 & 14.693 & 32,900 & $m$ \\
\hline Tennebsee & 1.3 & 28,283 & 3,545 & 720 & 9.872 & 233 & 0.452 & & .141 & 49,246 & 16.795 & 53.663 & 645 \\
\hline Venwont & 0 & & & & & & & & & & & & D \\
\hline virginte & 11 . & 18,812 & 24,356 & 4.492 & 922 & & 3,612 & & & 52,194 & 15,536 & 31,700 & 47 \\
\hline West VIrginis & B & 37,345 & 3,576 & 201 & 1,272 & 19,180 & & & 322 & 61,976 & 19,462 & 61,134 & 175 \\
\hline Misconsin & 11 & 20,755 & 781 & 84 & 3.612 & & 1.034 & & & 26.264 & 12,884 & 30,038 & 150 \\
\hline Total & 271 & 409.056 & 330.513 & 16,970 & 216,076 & 158,561 & 80.711 & 16,292 & 12,157 & $1,249,146$ & 300,203 & 926,575 & 11,243 \\
\hline
\end{tabular}


County

Midland, Michigan

Wayne, Michigan

Bay, Florida

Escambia, Florida

Summit, Ohio

Porter, Indiana

Mahoning, Ohio
Quantity, $10^{12}$ Btu/yr

26

25

24

21

21

21

20

Total läge industrial boiler fuel consumption exceeded $10 \times 10^{12}$ Btu/yr in 33 counties in the study area.

The majority of the large boiler facilities were in the pulp and paper, chemicals, iron and steel, and petroleum industries. A variety of other industrial categories, including miscellaneous manufacturing; food products, and textiles, accounted for the remainder.

Direct-Fired Point Sources--

The 956 direct-fired point sources (plants) in the study area consumed an annual $1960.78 \times 10^{12}$ Btu of fuel, and accounted for 5.5 percent of the total fuel consumed in the study area (Table 3-1). Table 3-7 summarizes fuel consumption and emissions for the 35 facility types analyzed in the study. An estimated 3.2 percent of the $\mathrm{NO}_{\mathrm{x}}$ emissions, 2.0 percent of the $\mathrm{SO}_{\mathrm{x}}$ emissions, and 0.5 percent of the HC emissions were generated by directfired sources (Table 3-1). The top 15 energy-consuming facility types accounted for 97 percent of both the direct-fired energy consumption and the total emissions of $\mathrm{NO}_{\mathrm{x}}, \mathrm{SO}_{\mathrm{x}}$, and $\mathrm{HC}$. The remaining 20 facility types accounted for only 3 percent of both the energy and total combustion emissions within this component of the industrial sector. This indicates that the $100 \times 10^{9}$ 

TABLE $3-7.5$ SUMMARY OF FUEL CONSUMPTION AND NO ${ }^{\prime} \mathrm{SO}_{x}$,
AND HC EMISSIONS FOR DIRECT-FIRED POINT SOURCE

FACILITIES IN THE EASTERN UNITED STATES

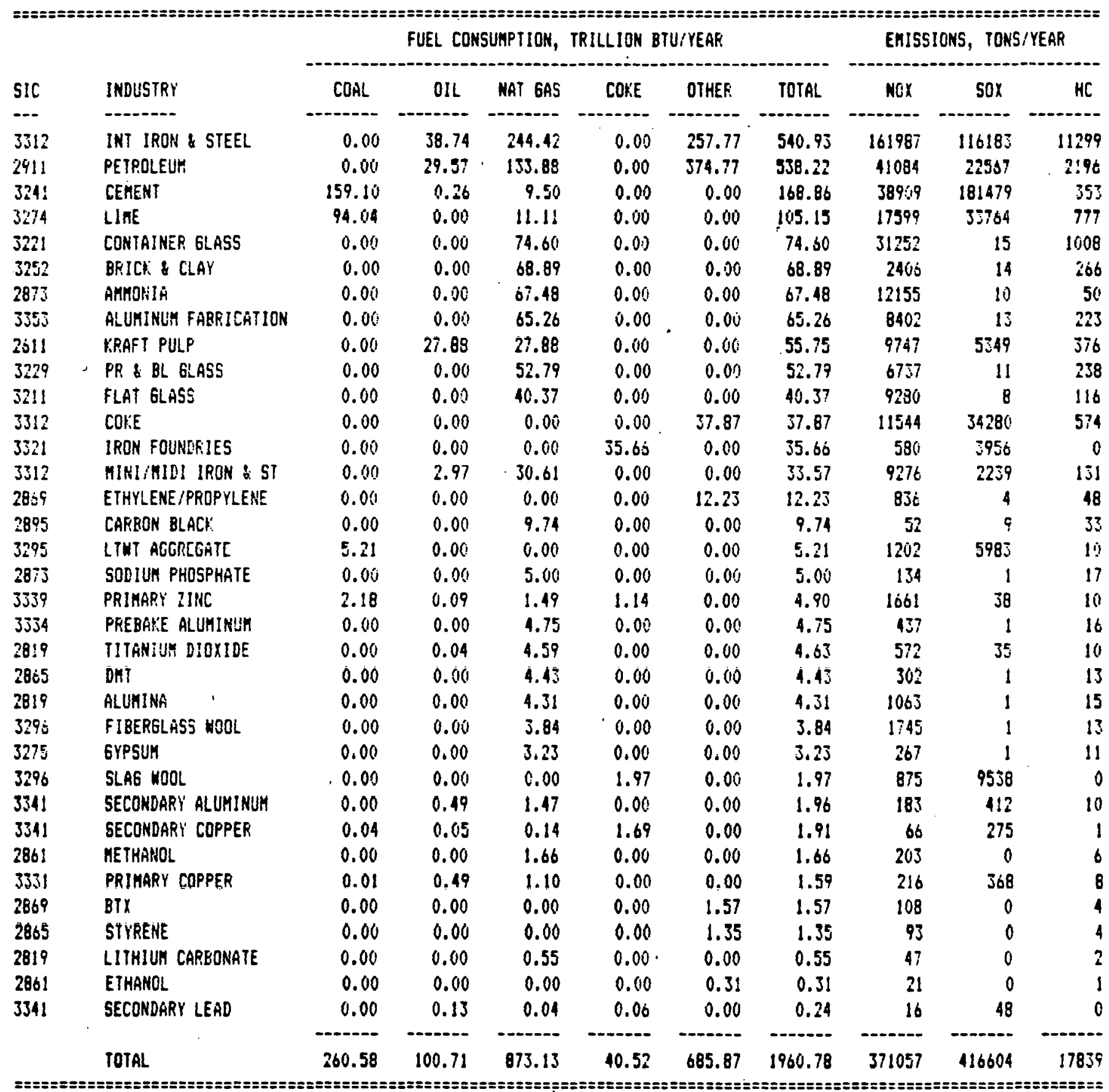


Btu/yr per plant cutoff value established to classify directfired plants as point sources (see section 2.1) is very conservative, and it is likely that no major direct-fired process has been missed.

\section{Industrial Area Sources--}

The industrial area sources consumed an annual $5374.7 \times 10^{12}$ Btu of fuel, and accounted for 15 percent of the fuel consumed in the study area (Table 3-1). An estimated 13.3 percent of the $\mathrm{NO}_{x}$ emissions ( 1.5 million tons/yr), 17.8 percent of the $\mathrm{SO}_{\mathrm{x}}$ emissions $(3.7$ million tons/yr), and 0.6 percent of the HC emissions $(20,947$ tons/yr) were produced by industrial area sources (Table $3-1)$.

The fuel and emission estimates are high because of double counting of emissions from coking coal, (considered to be a feedstock) in some of the states in the study area. It is estimated that the fuel total should be reduced by approximately $1,477 \times 10^{12}$ Btu to compensate for the over-estimate of coal consumption. Nitrogen oxide emissions should be reduced by about 1,000,000 tuns, $50_{x}$ emissions by 2,473,000 tons, and HC emissions by 2,900 tons. This will be done in subsequent work on the data base.

The industrial area sources are based on the number of manufacturing establishments per county. This approach to apportioning fuel use to counties tended to bias the fuel consumption in at least two places in the study area--Indiana and New York City. In Indiana, not enough of the area source energy consumption was believed to be directed to Lake County, where there is a large 
concentration of industrial sources; as a result, other counties in Indiana showed higher area source energy consumption than would be expected in that State. In New York the opposite was true, in that about 40 percent of the total industrial area source energy consumption was being allocated to New York County.

A more accurate approach appears to be the use of the number of manufacturing employees per county for apportioning industrial area source energy consumption to each county in a state." This approach will be used in subseguent work. Based on preliminary calculations, use of this method would increase the contribution of residual energy consumption in Lake County, Indiana, for example, from 5 to 13 percent, and reduce the amount apportioned to New York County from 40 percent to 23 percent.

\section{3 EMISSION PATTERNS}

Emission patterns are described best by emission density values (despite the limitations discussed earlier). Density values at the state level are the most reliable for comparisons because actual fuel consumption data are accumulated for individual states. County emission densities can be less reliable because of the assumptions made in prorating state fuel consump- . tion values to individual counties. Un the other hand, county emission densities show more discrete emission concentrations and. more detailed emission patterns. All the state-level densities for each sector and the selected county-level densities discussed in the following subsection illustrate the kind of analyses that emission densities will permit. 


\subsubsection{All Sectors}

Figure 3-1 presents emission densities of $\mathrm{NO}_{\mathbf{x}}$, SO $\mathrm{x}^{\prime}$ and $\mathrm{HC}$ by state for all sectors combined. The states having highest overall densities for $\mathrm{NO}_{\mathbf{x}}$ are New Jersey, Massachusetts, and Maryland, followed closely by Ohio, Pennsylvania, Rhode Island, Delaware, Connecticut, and Indiana. The states with the highest So ${ }_{x}$ emission densities are Ohio, Indiana, and Pennsylvania, followed, closely by West Virginia, Delaware, and Massachusetts. The $\mathrm{so}_{\mathrm{x}}$ emissions in the remaining states are generally in the low to medium range.

Hydrocarbon emission densities are generally much lower than those for $\mathrm{NO}_{\mathrm{X}}$ and $\mathrm{SO}_{\mathrm{x}}$; the states with the highest densities are in the northeast, i.e., New Jersey, Rhode Island, Massachusetts, and̈ Connecticut.

Although the state-level data do not show significant concentrations of emissions within the states, they do reflect the higher level of emissions in the highly industrial Midwest and Northeast.

\subsubsection{Area Sources (Iransportation, Commercial/Residential)}

As discussed previously, the transportation portion of the area sources dominates the emission densities of $\mathrm{NO}_{x}$ and $\mathrm{HC}$. Figure 3-2 shows, by state, the emission densities of ${ }^{\mathrm{NO}}{ }_{\mathrm{x}}, \mathrm{SO}_{\mathrm{x}}{ }^{\prime}$ and HC generated by these sectors. "The northeastern states of New Jersey, Rhode Island, and Massachusetts show the highest NO$_{\mathbf{x}}$ and HC densities, and it is obvious that these area sources constitute a large portion of the total emission densities in these states $(70$ to 1008$)$. 


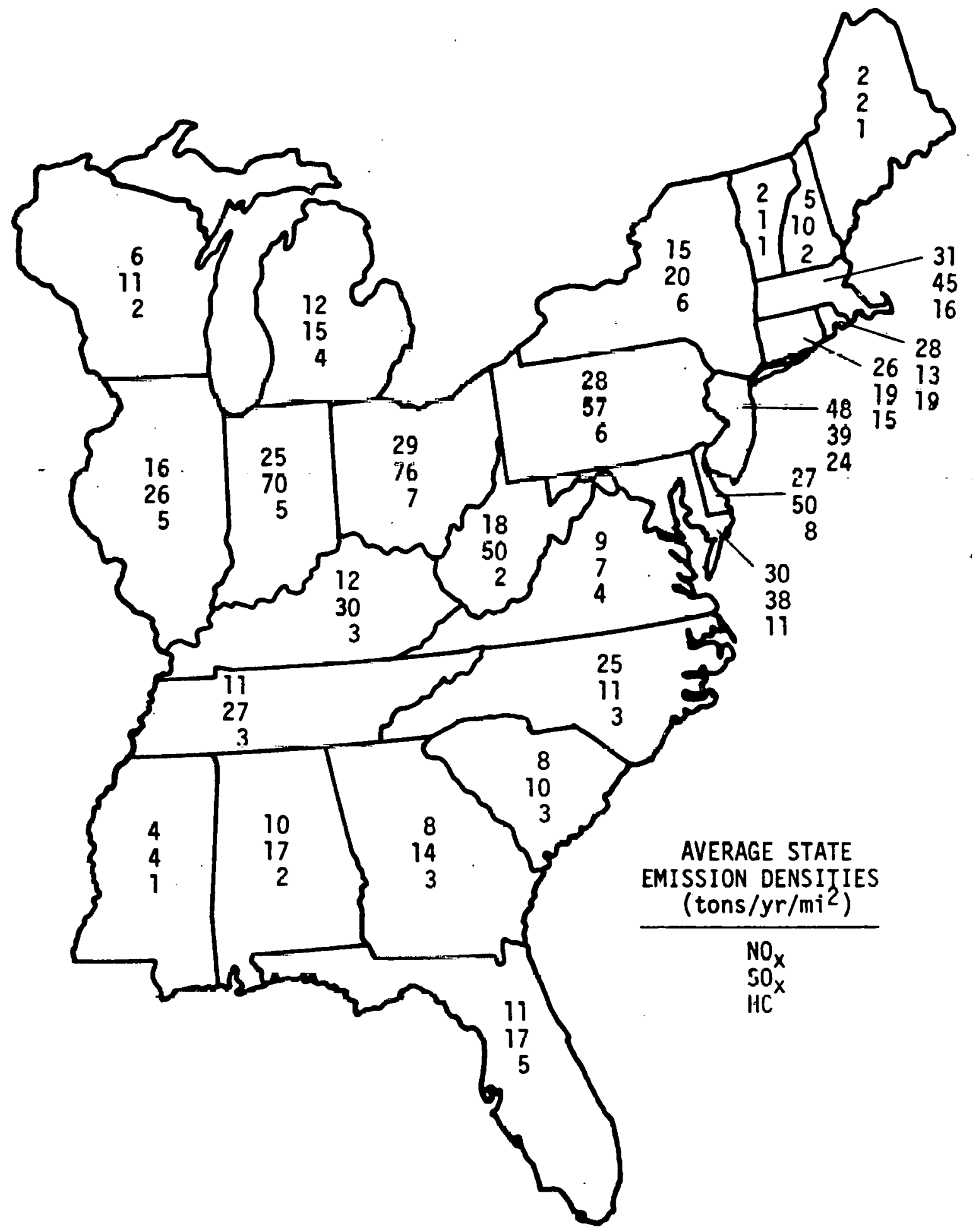

Figure 3-1. State combustion emission densities (tons/mi ${ }^{2}$ per $\mathrm{yr}$ ) for all sectors in the eastern United States. 


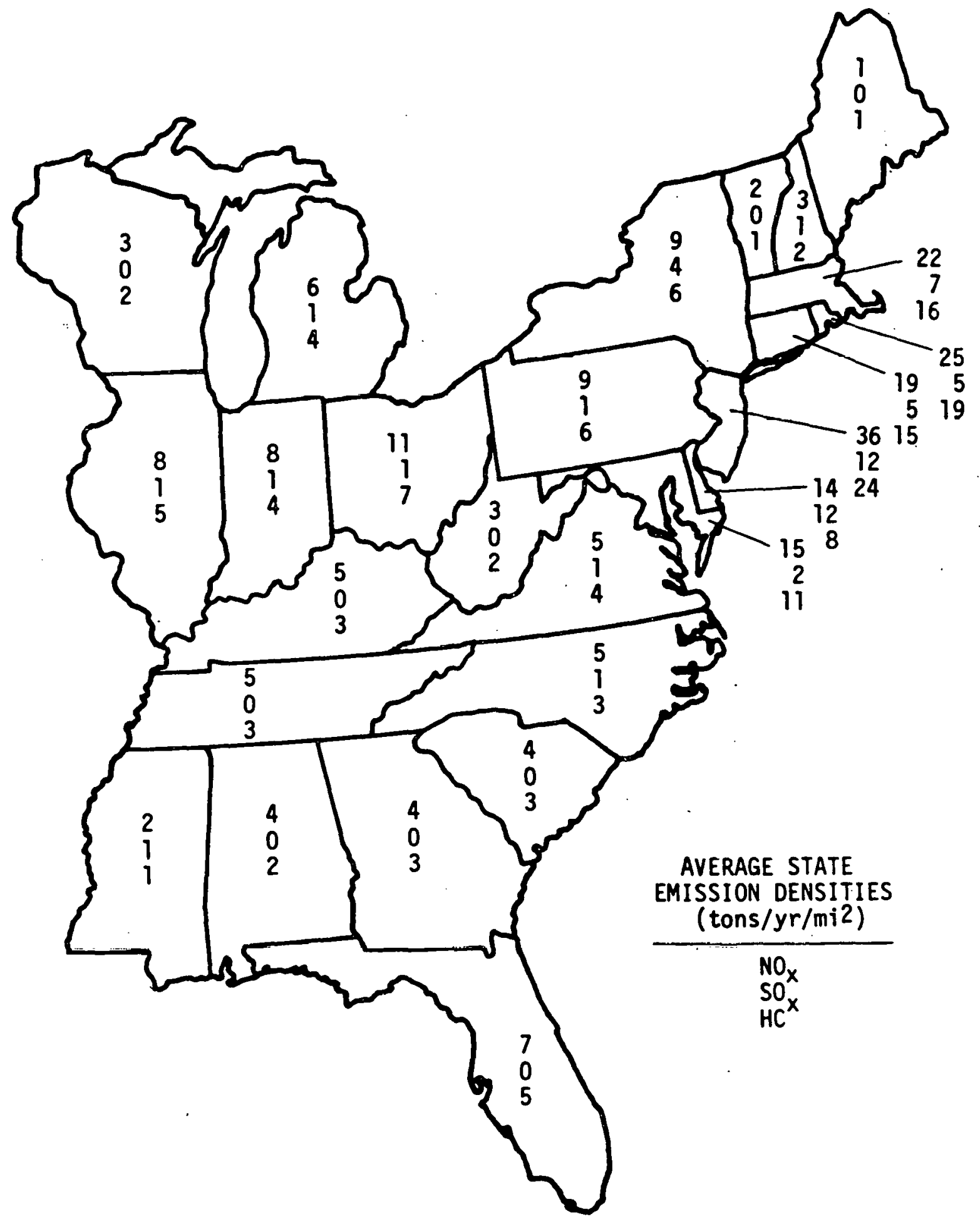

Figure 3-2. State combustion emission densities (tons $/ \mathrm{mi}^{2}$ per $\mathrm{yr}$ ) for the transportation, commercial/residential sectors in the eastern United States. 
Although $\mathrm{SO}_{\mathrm{x}}$ emissions are very low or negligible in almost all states, the aforementioned northeastern states show somewhat higher so ${ }_{x}$ densities. This is attributable to the general use of clean fuels except in the Northeast, where a substantial amount of sulfur-containing heating oil is burned.

\subsubsection{Utility Sector}

Figure 3-3 shows, by state, the emission densities for ${ }^{\prime}{ }_{x}$ ' SO $_{\mathrm{x}}$, and $\mathrm{HC}$ for the utility sector. The states with the highest densities of $\mathrm{NO}_{x}$ are ohio and West Virginia, tollowed by Pennsylvania, Deláwäre, New Jersey, Massachusetts, Maryland, and Indiana. These utility $\mathrm{NO}_{\dot{x}}$ emission densities account for 25 to 40 percent of total-sector $\mathrm{NO}_{\mathbf{x}}$ emission densities in these states. The So $_{x}$ emission densities, as expected, are also highest in the Midwestern states of Ohio, Indiana, and West Virginia, followed by Massachusetts, Pennsylvania, Delaware, Kentucky, and Tennessee. The utility-sector so emissions account for about 60 to 85 percent of the total-sector so $_{x}$ emission densities for these states. The so $_{x}$ data reflect the impact of coal burning in powerplants in Dhio, West Virginia, Pennsylvania, and Indiana. The high values in Delaware, New Jersey, Massachusetts, and Maryland are the result of residual oil burning in these relatively small states.

Utility HC emission densities are negligible for all states in the study area. 


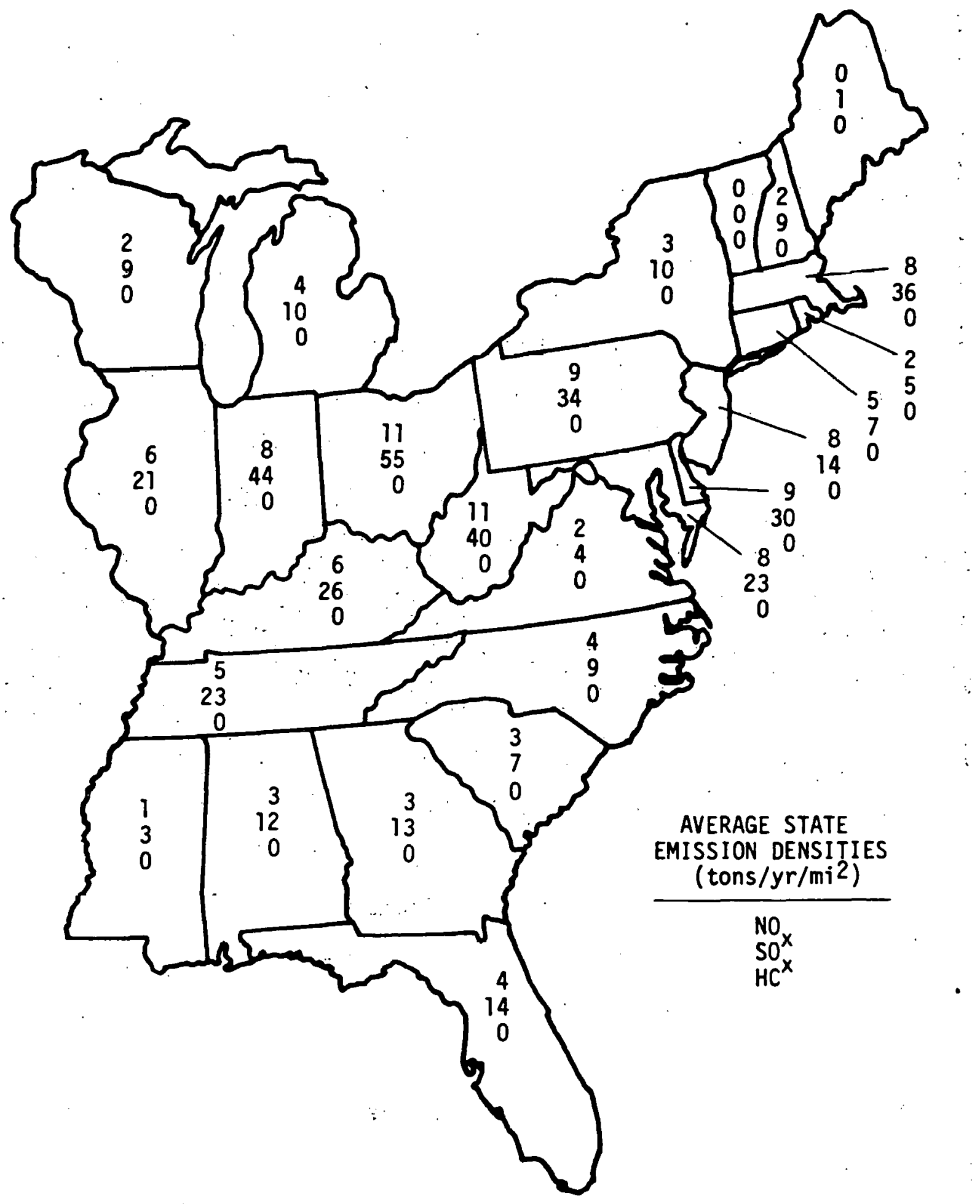

Figure 3-3. State combustion emission densities (tons $/ \mathrm{mi}^{2}$ per $\mathrm{yr}$ ) for the utility sector in the eastern United States. 


\subsubsection{Industrial Sector (Boilers, Direct-Fired Point Sources, and Industrial Area Sources)}

Figure 3-4 shows, by state, the emission densities for ${ }^{N}{ }_{x}$ " SO $_{\mathbf{x}}$, and $\mathrm{HC}$ in the industrial sector. As these data show, Indiana, Obio, and Pennsylvania are dominant as far as Industrial activity is concerned. The industrial sector accounts for between 26 and 38 percent of the $\mathrm{NO}_{x}$ and $\mathrm{SO}_{\mathbf{x}}$ emissions in these states.

On county density maps with combined $\mathrm{NO}_{\mathrm{x}}$ and $3 \mathrm{O}_{\mathrm{x}}$ el! issions shown shaded to indicate density (not presented here), industrial activity is reflected as a band that extends from Indiana through Pennsylvania and shows higher densities clustered around major industrial centers in northwest Indiana, eastern Ohio/western Pennsylvania, and eastern Pennsylvania. This band of industrial facilities is shown in Figure 3-5.

Although emiesions data have been computerized, the generation of isopleths or density maps to display county-to-county variations was not possible during the development of the report. This capability will be developed for future studies.

Table 3-8 presents an example of the extreme variability in emission density by county found throughout the study area by summarizing emission density by sector for all the counties in New Jersey. This table illustrates that No $\mathrm{x}_{\mathbf{x}}$ and $\mathrm{SO}_{\mathbf{x}}$ emissions from traditional area sources and industrial sources are frequently on the same level as utility emissions in many counties, and that they dominate the emission levels in counties where utilities are not present. 


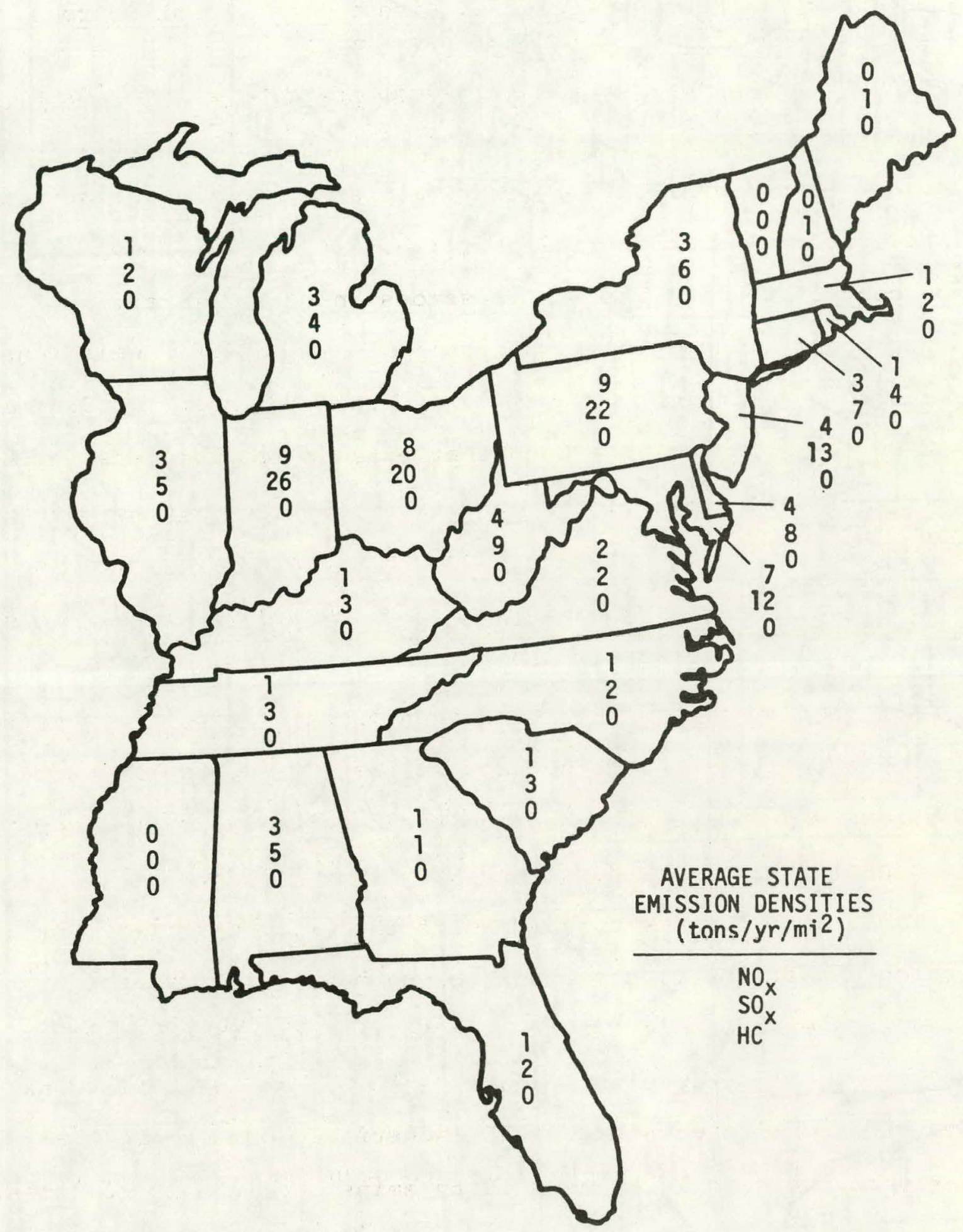

Figure 3-4. State combustion emission densities (tons $/ \mathrm{mi}^{2}$ per $\mathrm{yr}$ ) for the industrial sector in the eastern United States. 


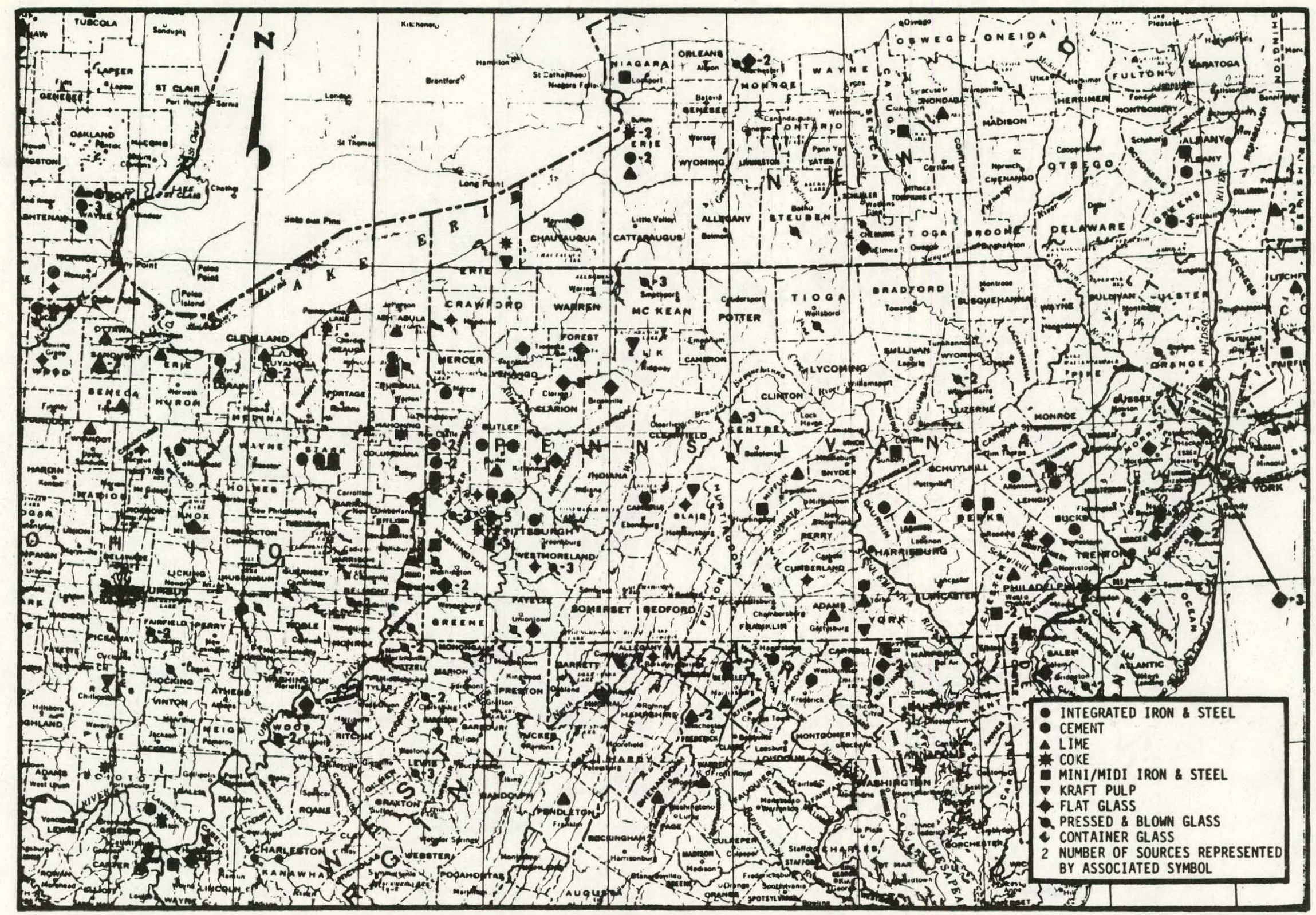

Figure 3-5. Distribtion of major direct-fired facility types from Indiana through Pennsylvania 
TABLE 3-8. SUMMARY OF COUNTY ${ }^{N O}{ }_{x}$ AND SO ${ }_{x}$ EMISSION DENSITIES BY SECTOR FOR NEW JERSEY

\begin{tabular}{|c|c|c|c|c|c|c|c|c|c|c|c|c|c|c|c|}
\hline \multirow[b]{3}{*}{ Mew Jersey } & \multicolumn{15}{|c|}{ Enission density (ton/sq. ml.) } \\
\hline & \multicolumn{3}{|c|}{ Trinsportat ion } & \multicolumn{3}{|c|}{ Utility } & \multicolumn{3}{|c|}{ Comercial/residential } & \multicolumn{3}{|c|}{ Industrial. } & \multicolumn{3}{|c|}{ All sectors } \\
\hline & ${ }^{N 0}{ }_{x}$ & ${ }^{50}{ }_{x}$ & 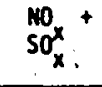 & ${ }^{n O_{x}}$ & ${ }^{{ }^{5}}{ }_{x}$. & SO $_{\text {SO }_{x}^{x}}^{+}$ & ${ }^{10}{ }_{x}$. & so $_{x}$ & ${ }_{{ }_{50}^{M 0}}^{\mathrm{NO}}+$ & $100_{x}$ & ${ }^{50}{ }_{x}$ & ${ }^{\mathrm{NO} 0_{x}^{x}}+$ & ${ }^{N O}{ }_{x}$ & ${ }^{50}{ }_{x}$ & $\begin{array}{l}\mathrm{NO}_{\mathrm{X}}^{\mathrm{x}}+ \\
\mathrm{SO}_{\mathrm{x}}\end{array}$ \\
\hline Atlantic & 10.48 & 0.73 & 11.21 & 0.15 & 0.03 & 0.18 & 1.65 & 3.45 & 5.10 & 0.37 & 2.09 & 2.46 & 12.66 & 6.30 & 18.96 \\
\hline Bergen & 123.66 & 8.60 & 132.26 & 29.53 & 4.19 & 33.72 & 17.53 & 36.60 & 54.13 & 11.53 & 54.96 & 66.49 & $182.25^{\circ}$ & 104.35 & 286.60 \\
\hline Burlington & 13.71 & 0.95 & 14.66 & i. 74 & 1.89 & 3.63 & 2.15 & 4.49 & 6.64 & 1.03 & 2.44 & 3.47 & 18.63 & 9.77 & 28.40 \\
\hline Canden & 66.20 & 4.61 & 70.81 & $\boldsymbol{J}$ & 0 & 0 & 10.35 & 21.61 & 31.96 & 5.41 . & i8.17 & 23.58 & 81.96 & 44.39 & 126.35 \\
\hline Cope May & 10.33 & 0.72 & 11.05 & 26.25 & 158.32 & 184.57 & 1.49 & 3.11 & 4.60 & 0.23 & 1.32 & 1.55 & 38.31 & 163.47 & 201.78 \\
\hline Cumberland & 8.64 & 0.60 & 9.24 & 2.89 & 9.51 & 12.40 & 1.29 & 2.69 & 3.98 & 5.44 & 2.45 & 7.89 & 18.26 & 15.26 & 33.52 \\
\hline Essex & 158.69 & 11.04 & 169.73 & 9:80 & 0,91 & 10.71 & 31.73 & 66.27 & 98.00 & 15.58 & 86.58 & 102.16 & 215.80 & 164.80 & 380.60 \\
\hline Gloucester & 18.61 & 1.29 & 19.90 & 0.32 & 0.09 & 0.41 & 2.95 & 6.16 & 10.77 & 14.05 & 14.32 & 28.37 & 35.93 & 21.85 & 57.58 \\
\hline Hudson & 255.34 & 17.77 & 273.11 & 322.70 & 464.81 & 787.51 & 57.49 & 120.02 & 177.51 & 72.91 & 255.19 & 328.10 & 708.45 & 857.79 & 1566.24 \\
\hline munterdon & 7.71 & 0.54 & 8.25 & E.53 & 2.55 & 8.08 & 1.00 & 2.09 & 3.09 & 0.26 & 1.46 & 1.72 & 14.50 & 6.65 & 31.15 \\
\hline Murcer & 45.78 & 3.18 & 48.96 & 41.87 & 105.00 & 146.87 & 6.54 & 13.69 & 20.23 & 1.86 & 10.39 & 12.25 & 96.06 & 132.25 & 228.31 \\
\hline Middlesex & 62.71 & 4.37 & 67.08 & $3 i .70$ & 10.93 & 48.63 & 9.27 & 19.34 & 28.61 & 13.59 & 33.73 & 47.32 & 123.27 & 68.37 & 191.64 \\
\hline Monnouth & 35.57 & 2.47 & 38.04 & 0 & 0 & 0 & 5.13 & 10.71 & 15.84 & 3.69 & 6.13 & 9.82 & .44 .39 & 19.31 & 63.70 \\
\hline Morris & 31.17 & 2.17 & 33.34 & o & 0 & 0 & 4.23 & 8.82 & 13.05 & 3.40 & 10.91 & 14.31 & 38.80 & 21.90 & 60.70 \\
\hline Oceen & 17.92 & 1.25 & 19.17 & o & 0 & 0 & 2.61 & 5.46 & 8.07 & 0.85 & 2.85 & 3.70 & 21.38 & 9.56 & 30.94 \\
\hline Passalc & 75.17 & 5.23 & 80.40 & 0 & 0 & 0 & 11.31 & 23.62 & 34.93 & 9.51 & 49.04 & 58.55 & 95.99 & 77.89 & 173.88 \\
\hline Salem & 5.66 & 0.39 & 6.05 & $\therefore .23$ & 8.42 & 15.65 & 0.86 & 1.80 . & 2.66 & 1.26 & 0.86 & 2.12 & 15.02 & 11.47 & 26.49 \\
\hline Somerset & 19.98 & 1.39 & 21.37 & 0 & 0 & 0 & 3.21 & 6.70 . & 9.91 & 1.99 & 4.69 & 6.68 & 25.18 & 12.78 & 37.96 \\
\hline Sussex & 7.55 & 0.53 & .8 .08 & 0 & 0 & 0 & 1.07 & -2.23 & 3.30 & 0.38 & 3.28 & 3.66 & 8.99 & 6.04 & 15.03 \\
\hline Union & 186.20 & 12.95 & 199.15 & 23.95 & 21.38 & 51.33 & 23.73 & 49.57 & 73.30 & 37.94 & 89.74 & 129.48 & 277.83 & 173.64 & 451.47 \\
\hline Mriren & 8.50 & 0.59 & 9.09 & 0 & 0 & 0 & 1.14 & 2.36 & 3.50 & 0.37 & 2.10 & 2.47 & 10.01 & 5.06 & 15.07 \\
\hline $\begin{array}{l}\text { State } \\
\text { density }\end{array}$ & 30.81 & 2.14 & 32.95 & B.35 & 14.00 & 22.35 & 4.75 & 9.92 & 14.67 & 4.47 & 12.75 & 17.22 & 48.38 & 39.80 & 87.18 \\
\hline
\end{tabular}




\subsubsection{Emission Patterns in the Three Areas Chosen for Additional Study}

Emission density maps on a county-by-county basis were made up for a number of different sector combinations and evaluated for emission patterns. Three areas in the eastern United States were chosen as sites for the evaluation of wet deposition monitoring data. These areas were: 1) the Hudson River Valley of New York State, 2) the eastern Ohio/wegtern Pennsylvania border ared, and 3) the 'l'ennessee/North Carolina border area.

Comparison of the Three Study Areas--

These three areas had 47 counties that showed either $\mathrm{SO}_{\mathrm{x}}$ or NO $x$ emission densities over 100 tons $/ \mathrm{mi}^{2}$ per year. Because analysis of data for all counties in the three regions was beyond the scope of this study, these 47 were evaluated to compare sectors and regions. Table 3-9 presents total emissions of No $x^{\prime}$ SO $x$, and $H C$ for the sum of these counties by study area. Emission densities for $\mathrm{NO}_{\mathrm{x}}, \mathrm{SO}_{\mathrm{x}}, \mathrm{HC}$, and all pollutants combined are shown in Table 3-10 for the 47 counties. For the 19 high density counties in the Hudson River Valley area, $\mathrm{NO}_{\mathbf{x}}$ densities ranged from 63 tons $/ \mathrm{mi}^{2}$ per year in York County, Ponnaylvania, Lu uver 2200 tons $/ \mathrm{mi}^{2}$ per year in New York County, New York. For So the range was from 68 tons $/ \mathrm{mi}^{2}$ per year for Midalesex County, New Jersey, to over 3700 tons $/ \mathrm{mi}^{2}$ per year in New York County, New York. For HC's, the range was 4.7 tons $/ \mathrm{mi}^{2}$ per year for Montour, Pennsylvania, to 365 tons $/ \mathrm{mi}^{2}$ per year for New York County, New York. 
TABLE 3-9. TOTAL EMISSIONS BY REGION FOR ALL COUNTIES WITH $>100$ tons $/ \mathrm{mi}^{2}$ per yr. $\mathrm{FOR} \mathrm{NO}{ }_{x} \mathrm{OR} \mathrm{SO}_{x}$

\begin{tabular}{|c|c|c|c|c|}
\hline \multicolumn{5}{|c|}{ Hudson River Valley (19 counties) } \\
\hline \multirow[b]{2}{*}{ Pollutant } & \multicolumn{4}{|c|}{ Emissions, tons/yr } \\
\hline & $\begin{array}{c}A 11 \\
\text { sectors }\end{array}$ & $\begin{array}{l}\text { Area } \\
\text { sources }\end{array}$ & Utility & Industrial \\
\hline $\mathrm{NO}_{x}$ & 810.6 & 394.2 & 220.5 & 196.6 \\
\hline $\mathrm{SO}_{\mathrm{x}}$ & 1126.8 & 146.4 & 481.5 & 498.9 \\
\hline$H C^{\wedge}$ & 264.5 & 258.3 & 1.9 & 4.2 \\
\hline Totals & 2201.9 & 404.7 & 703.9 & 699.7 \\
\hline
\end{tabular}

Ohio/Pennsylvania (19 counties)

\begin{tabular}{l|r|r|r|r}
\hline \multirow{2}{*}{ Pollutant } & \multicolumn{4}{|c}{ Emissions, tons/yr } \\
\cline { 2 - 5 } & $\begin{array}{c}\text { All } \\
\text { sectors }\end{array}$ & $\begin{array}{c}\text { Area } \\
\text { sources }\end{array}$ & Utility & Industrial \\
\hline NO $_{\mathrm{X}}$ & 883.7 & 186.9 & 494.6 & 140.0 \\
$\mathrm{SO} \mathrm{X}$ & 3042.6 & 20.1 & 2552.2 & 309.9 \\
$\mathrm{HC}$ & 124.0 & 117.3 & 2.7 & 3.0 \\
\hline Totals & 4050.3 & 324.3 & 3049.5 & \multicolumn{1}{c}{452.9} \\
\hline
\end{tabular}

.. North Carolina/Tennessee ( 9 counties)

\begin{tabular}{l|r|r|r|r}
\hline \multirow{2}{*}{ Pollutant } & \multicolumn{4}{|c}{ Emissions, tons/yr } \\
\cline { 2 - 5 } & $\begin{array}{c}\text { All } \\
\text { sectors }\end{array}$ & $\begin{array}{c}\text { Area } \\
\text { sources }\end{array}$ & Utility & Industrial \\
\hline NO $_{X}$ & 300.0 & 25.9 & 269.4 & 88.5 \\
SO $_{X}$ & 770.7 & 2.4 & 757.1 & 218.3 \\
HC & 5.4 & 17.5 & 1.5 & 5.4 \\
\hline Totals & 1076.1 & 45.8 & 1028.0 & 312.2 \\
\hline
\end{tabular}


TABLE 3-10. REGIONAL DENSITIES FOR ALL POLLUTANTS AND ALL SECTORS (tons $/ \mathrm{mi}^{2}$ per $\mathrm{yr}$ )

\begin{tabular}{l|r|r|r|r}
\hline \hline & All & ${ }^{N_{X}}$ & $\mathrm{SO}_{\mathrm{x}}$ & $\mathrm{HC}$ \\
\hline Hudson River Valley & & & & \\
All sectors & 545 & 201 & 279 & 65 \\
Area sources & 190 & 98 & 36 & 64 \\
Utility & 174 & 55 & 119 & 0 \\
Industrial & 173 & 49 & 123 & 1 \\
\hline Ohio/Pennsylvania & & & & \\
All sectors & & & & \\
Area sources & 482 & 105 & 362 & 15 \\
Utility & 39 & 22 & 2 & 14 \\
Industrial & 365 & 59 & 305 & 0 \\
\hline North Carolina/Tennessee & 79 & 24 & 55 & 0 \\
\hline All sectors & & & & \\
Area sources & 326 & 90 & 230 & 6 \\
Utility & 14 & 8 & 1 & 5 \\
Industrial & 307 & 80 & 226 & 0 \\
\hline \hline
\end{tabular}


These data illustrate several points. First, counties with very small areas such as New York County, New York, can display very high densities with relatively modest emissions. Secondly, they indicate that emission densities for HC's, primarily from transportation, can reach levels that make them a major contributor to the emissions in some counties even though they appear to play a minor role in the general picture. Comparable data for the ohio-Pennsylvania area are: $\mathrm{NO}_{\mathrm{x}}-22$ to 264 tons $/ \mathrm{mi}^{2}$ per $\mathrm{yr}, \mathrm{SO}_{\mathrm{x}}-110$ to 1118 tons $/ \mathrm{mi}^{2}$ per $\mathrm{yr}$, and $\mathrm{HC}-2$ to 81 tons $/ \mathrm{mi}^{2}$ per yr, comparable data for the North Carolina-Tennessee region are: ${ }^{N O} \mathrm{x}_{\mathrm{x}}-36$ to 123 tons $/ \mathrm{mi}^{2}$ per $\mathrm{yr}, \mathrm{SO}_{\mathrm{x}}-106$ to 553 tons $/ \mathrm{mi}^{2}$ per $\mathrm{yr}$, and $\mathrm{HC}-3$ to 13 tons $/ \mathrm{mi}^{2}$ per $\mathrm{yr}$.

These data are indicative of some of the fundamental differences in emission patterns in the three regions. Density values shown in Table 3-10 also illustrate the relative importance of different sectors. Those counties that have high-emission densities for $\mathrm{NO}_{x}$ or $\mathrm{SO}_{x}$ include ail of the large powerplants in the region while a very large portion of the emissions from other sectors are emanating from counties with lower emission densities. The data show that even with this bias, emissions in the Hudson River Valley are dominated by those originating from nonutility sources. The other two regions show very different patterns indicating that utilities are the dominant source in those counties with high emission densities. 
New York-Hudson River Valley--

This area was chosen because of the concern over acid precipitation in the Adirondack mountains and because the Hudson River Valley is downwind of a high concentration of area source emissions around New York City, New Jersey, and eastern Pennsylvania. This area also displays high strong seasonal patterns of surface wind directions that are important in demonstrating emission impacts.

Figures 3-6 and 3-7 present $\mathrm{NO}_{\mathrm{x}}$ and $\mathrm{SO}_{\mathrm{x}}$ emission densities for the New York Hudson River Valley study area. The high emission density area around New York City, New Jersey, and eastern Pennsylvania is readily discernable. The NADP stations evaluated are to the north of these high emission-density areas. Sector contributions in the counties with the highest densities vary widely. In many counties, a strung area source component is generally present and can account for the majority of emissione. In some counties, however, utility and industrial emissions are either dominant or of the same magnitude as the area source component. This observation is based on a review of individual counties for both the high-emission-density counties $\left(>100\right.$ tons/mi ${ }^{2}$ per $y r)$ and the low and medium density counties $\left(10\right.$ to $100 \mathrm{tons} / \mathrm{mi}^{2}$ per $y r)$. 


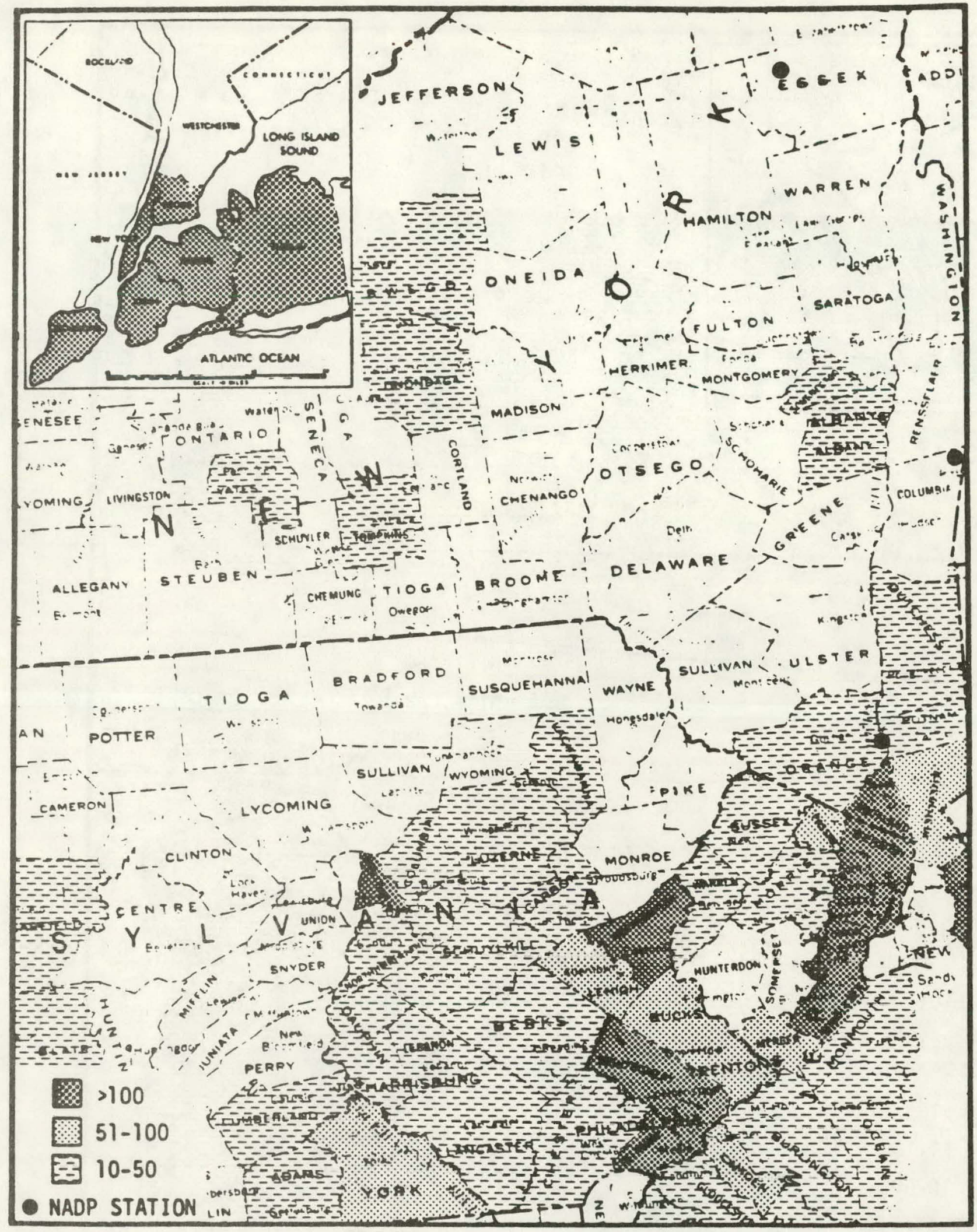

Figure $3 \approx 6$. Emission density ranges of $\mathrm{NO}_{\mathrm{x}}$ (tons $/ \mathrm{mi}^{2}$ per $\mathrm{yr}$ ) for all sectors combined in the New York Hudson River Valley study area. 


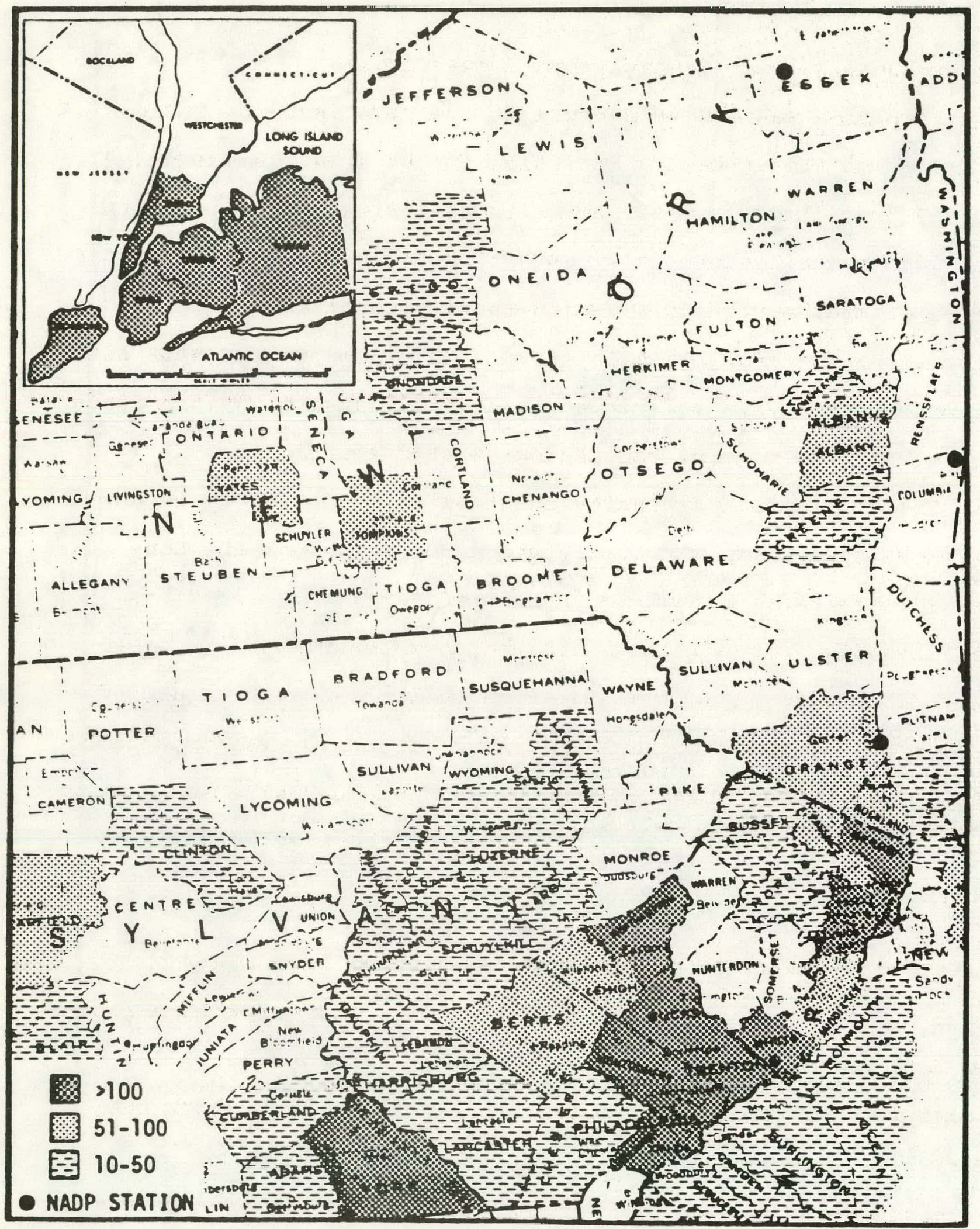

Figure 3-7. Emission density ranges of $\mathrm{SO}_{\mathrm{x}}$ (tons $/ \mathrm{mi}^{2}$ per $\mathrm{yr}$ ) for all sectors combined in the New York - Hudson River Valley study area. 
Eastern Ohio/Western Pennsylvania Border Area--

This area was chosen because of the high level of industrial activity and the number of utilities in the area. Figures 3-8 and 3-9 present $\mathrm{NO}_{\mathrm{x}}$ and $\mathrm{SO}_{\mathrm{x}}$ emission densities for all sectors combined in the eastern Ohio/western Pennsylvania study area. A number of medium to high-emission-density counties are located between the two NADP sites in eastern Ohio and the two NADP sites in western Pennsylvania. This entire study area gives the appearance of a large mass of combustion-related emissions.

The high-emission-density counties in Ohio tend to be dominated by utilities, especially where $\mathrm{So}_{\mathbf{x}}$ emissions are concerned, even though area and industrial sources do contribute significantly, especially in the medium-emission-density counties. This also holds true for high-emission-density counties in western Pennsylvania and northern West Virginia, with exceptions such as Allegheny County, Pennsylvania, and Hancock County, West Virginia, where all sectors contribute to the high emission density.

Tennessee/North Carolina Border Area--

This area was chosen as a control area for comparison with New York and Ohio/Pennsylvania. Emissions are generally low except for pockets of high emissions scattered throughout the area.

Figures 3-10 and 3-11 present $\mathrm{NO}_{\mathrm{X}}$ and $\mathrm{SO}_{\mathrm{x}}$ emission densities for the Tennessee/North Carolina border area. As in the Ohio/- 


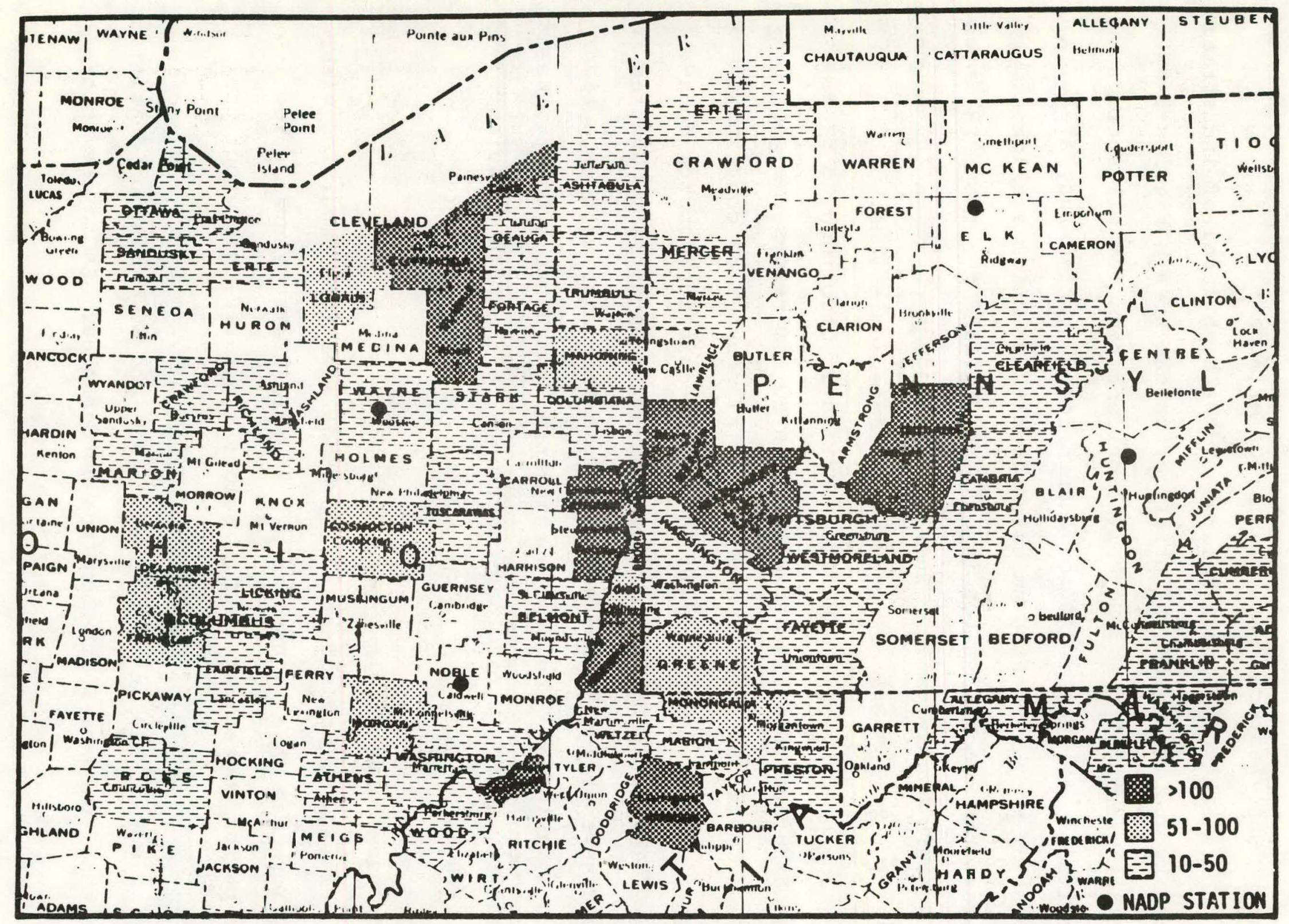

Figure 3-8. Emission density ranges of $\mathrm{NO}_{\mathrm{X}}$ (tons $/ \mathrm{mi}^{2}$ per $\mathrm{yr}$ ) by county for a11 sectors combined in the Ohio/Pennsylvania study area. 


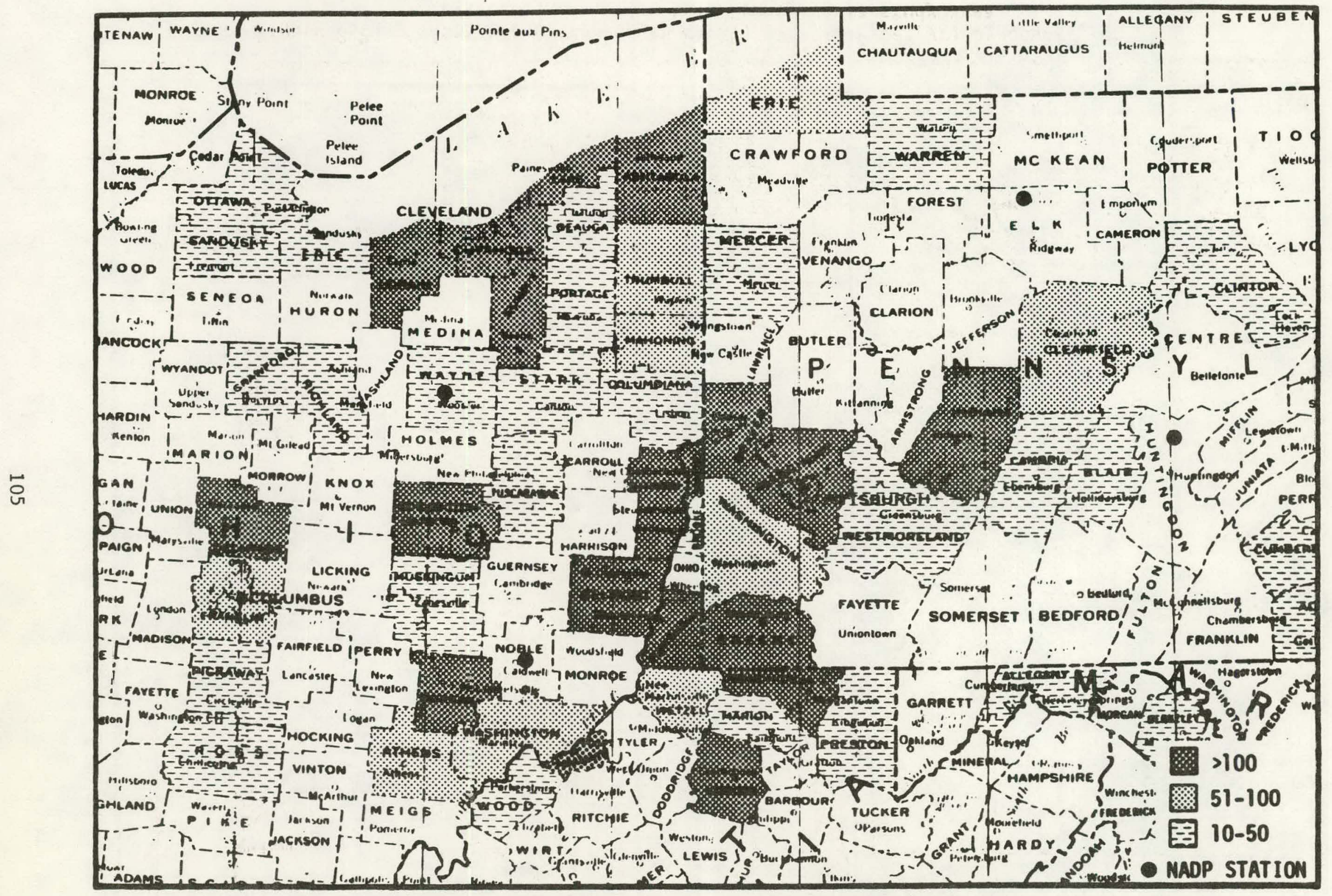

Figure 3-9. Emission density ranges of $\mathrm{SO}_{\mathrm{x}}$ (tons $/ \mathrm{mi}^{2}$ per $\mathrm{yr}$ ) by county for all sectors combined in the Ohio/Pennsylvania study area. 


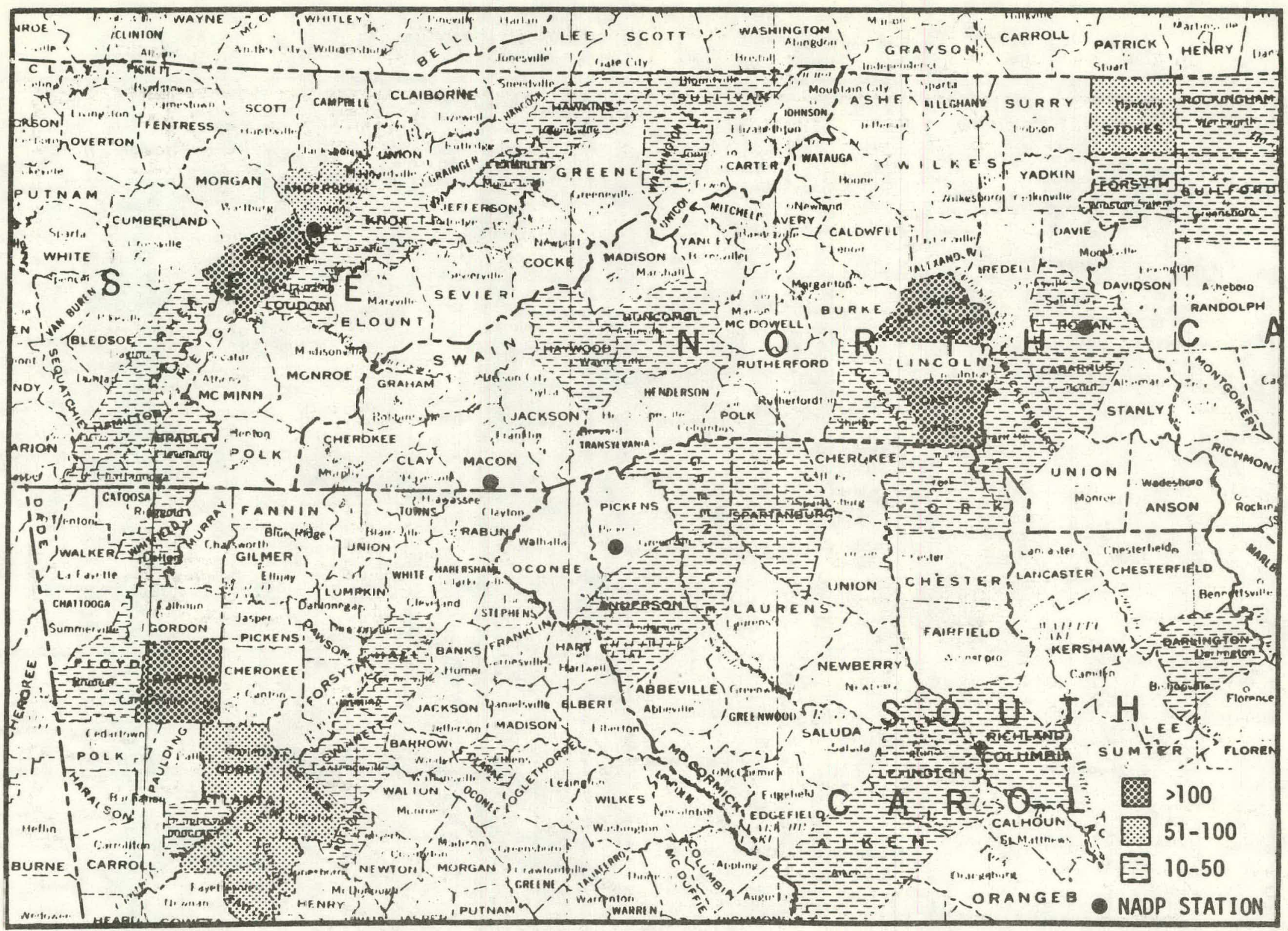

Figure 3-10. Emission density ranges of $\mathrm{NO}_{\mathrm{x}}$ (tons $/ \mathrm{yr} / \mathrm{mi}^{2}$ ) for all sectors combined in the Tennessee/South Carolina/North Carolina study area. 


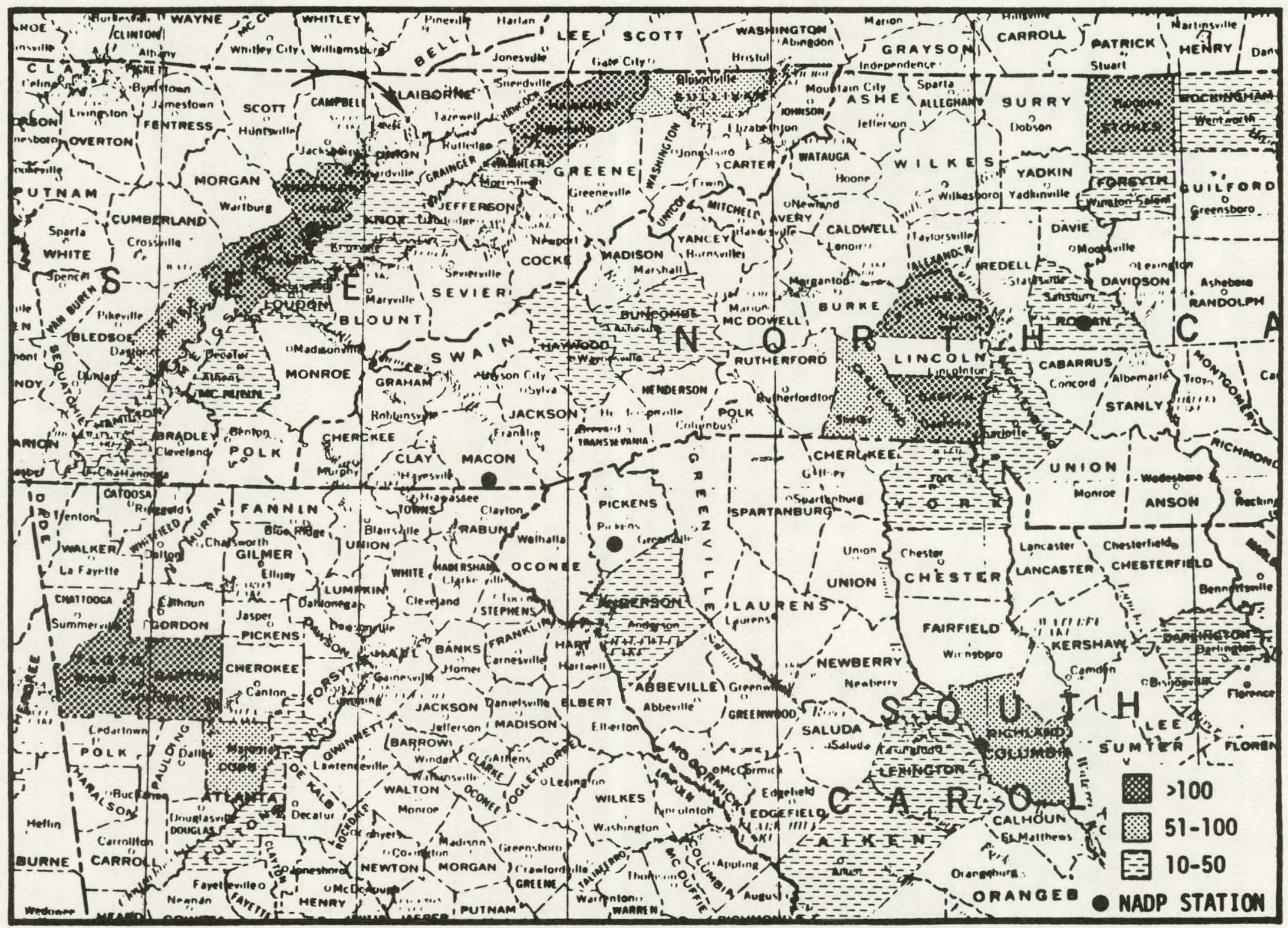

Figure 3-11. Emission density ranges of $\mathrm{SO}_{\mathrm{x}}$ (tons/mi2 per $\mathrm{yr}$ ) for all sectors combined in the Tennessee/South Carolina/North Carolina study area. 
Pennsylvania area, the high-emission-density counties $1>100$ tons $/ \mathrm{mi}^{2}$ per $\mathrm{yr}$ ) are dominated by utilities; the industrial and area sources (mostly transportation $\mathrm{NO}_{\mathbf{x}}$ ) occurring in all counties. The NADP stations in this area are distributed between the pockets of high-emission-density counties.

\subsection{COMPARISON OF NATIONAL, EASTERN U.S., AND STUDY AREA FUEL CONSUMPTION}

Table 3-11 presents a comparison of total fuel consumption in the United States and in the 26-state study area (as shown in the State Energy Data Report ${ }^{1}$ ), with fuel combustion in the fuel-usage categories considered in this study by individual fuel type. Table 3-12 presents this information for all fuel types by sector.

The difference between total fuel use in the study area and that considered in this study reflects fuel consumption omitted because of the strategy used to simplify the initial inventory development (Section 2).

For the most part, the fuel-use data tend to indicate that coverage of major fuel consumption is reasonably complete. The data further indicate that more of the fuels of greatest interest (coal and other "dirty" fuels that generate the most $\mathrm{NO}_{\mathrm{x}}$ and $\mathrm{SO}_{\mathrm{x}}$ emissions) are consumed in the eastern United States than in the rest of the country. This is especially true for coal; the study area accounts for almost 75 percent of the total.

The biggest discrepancy in the comparison by type of fuel (Table 3-12) appears to be in the category that includes "other solid and liquid fuels" used in the industrial sector. Except 
TABLE 3-11. FUEL CONSUMPTION ESTIMATES BY FUEL TYPES FOR THE STUDY AREA AND UNITED STATES

$\left(10^{12}\right.$ Btu per year)

\begin{tabular}{|c|c|c|c|c|c|}
\hline \multirow[b]{3}{*}{ Fuel type } & \multirow[b]{3}{*}{$\begin{array}{c}\text { Total U.S. } \\
\text { fuel } \\
(\text { SEDB })^{a}\end{array}$} & \multicolumn{4}{|c|}{ Twenty-six-state study area } \\
\hline & & \multirow[b]{2}{*}{$\begin{array}{l}\text { Total } \\
\text { fuel } \\
(\text { SEDB })^{a}\end{array}$} & \multicolumn{3}{|c|}{ Data base fuel consumption } \\
\hline & & & $\begin{array}{c}\text { Totàl } \\
\text { fuel used }\end{array}$ & $\begin{array}{l}\text { Percent } \\
\text { of study } \\
\text { area total }\end{array}$ & $\begin{array}{l}\text { Percent of } \\
\text { U.S. total }\end{array}$ \\
\hline Coal & 15,492 & 11,552 & 11,373 & 98.5 & 73.4 \\
\hline Residual oil & 5,772 . & 3,546 & 3,321 & 93.7 & 57.5 \\
\hline $\begin{array}{c}\text { Distillate oil } \\
\text { and kerosene }\end{array}$ & 6,439 & 4,011 & 3,876 & 96.6 & 60.2 \\
\hline $\begin{array}{l}\text { Natural gas } \\
\text { and } L P G\end{array}$ & 22,367 & 9,131 & 8,827 & 96.7 & 39.5 \\
\hline Motor gasoline & 12,648 & 7,505 & 7,386 & 98.4 & 58.4 \\
\hline $\begin{array}{l}\text { Other solid, } \\
\text { liquid, and } \\
\text { gaseous fuel }\end{array}$ & $5,079^{b}$ & 2,641 & 985 & 37.3 & 19.4 \\
\hline Total & 67,797 & 38,386 & 35,768 & 93.2 & 52.8 \\
\hline
\end{tabular}

a State Energy Data Report, 1980.1

b Estimate based on 1977 census data. 2

TABLE 3-12. FUEL COMBUSTION ESTIMATES BY SECTOR FOR THE STUDY AREA 'AND UNITED STATES

$\left(10^{12}\right.$ Btu per year)

\begin{tabular}{|c|c|c|c|c|c|}
\hline \multirow[b]{3}{*}{ Sector } & \multirow{3}{*}{$\begin{array}{l}\text { Total U.S. } \\
\text { fuel } \\
(\text { SEDB })^{a}\end{array}$} & \multicolumn{4}{|c|}{ Twenty-six-state study area } \\
\hline & & \multirow[b]{2}{*}{$\begin{array}{l}\text { Total } \\
\text { fuel } \\
\text { (SEDB) }\end{array}$} & \multicolumn{3}{|c|}{ Data base fuel consumption } \\
\hline & & & $\begin{array}{c}\text { Total } \\
\text { fuel used }\end{array}$ & $\begin{array}{l}\text { Percent } \\
\text { of study } \\
\text { area total }\end{array}$ & $\begin{array}{l}\text { Percent of } \\
\text { U.S. total }\end{array}$ \\
\hline $\begin{array}{l}\text { Transportation } \\
\text { Commercial } \\
\text { Residential } \\
\text { Utility } \\
\text { Industrial } \\
\end{array}$ & $\begin{array}{r}17,230 \\
4,092 \\
6,887 \\
18,597 \\
20,991 \\
\end{array}$ & $\begin{array}{r}9,482 \\
2,565 \\
4,703 \\
11,283 \\
10,348 \\
\end{array}$ & $\begin{array}{r}8,835 \\
2,423 \\
4,650 \\
11,275 \\
8,585 \\
\end{array}$ & $\begin{array}{l}93.2 \\
94.5 \\
98.9 \\
99.9 \\
83.0\end{array}$ & $\begin{array}{l}51.3 \\
59.2 \\
67.5 \\
60.6 \\
40.9\end{array}$ \\
\hline Total & 67,797 & 38,386 & 35,768 & 93.2 & 52.8 \\
\hline
\end{tabular}

a State Energy Data Report, 1980.1.

b Ineludes other fuel estimates based on 1977 Census data. ${ }^{2}$ 
for the stated 35 to 40 percent of the total, these could not be accounted specifically without effort beyond the scope of this study. A more complete accounting will be made in followup studies.

In the data by consuming sectors (Table 3-12), the largest discrepancy in fuel use coverage is in the industrial and transportation sectors. Again, the variation in the industrial sector is due in large part to the failure to include all "other" fuels discussed above. The discrepancy in the transportation sector results from the exclusion of fuels used in ships, aircraft, and pipeline compressors. The impact of excluding these fuel uses for emission estimates was negligible except for pipeline compressors; during the study these were belatedly proven to be significant producers of $\mathrm{NO}_{\mathrm{x}}$. For followup studies, pipeline compressor fuel use will be included with industrial area sources. In addition to the above comparisons, a check was made to determine the impact of limiting the study to combustion sources (as opposed to all sources, including noncombustion processes). Comparison of NEDS data (Table 3-13) for combustion and noncombustion sources illustrates the effect of this limitation on the amounts of $\mathrm{NO}_{\mathbf{x}}, \mathrm{SO}_{\mathbf{x}}$, and $\mathrm{HC}$ included in the study.

TABLE 3-13. COMPARISON OF COMBUSTION. AND NONCOMBUSTION EMISSIONS ${ }^{3}$

\begin{tabular}{c|c|c|c}
\hline & $\begin{array}{c}\text { Total } 1980 \text { NEDS emissions, } \\
10^{6} \text { tons/yr }\end{array}$ & $\begin{array}{c}\text { NEDS combustion } \\
\text { emissions, 106 tons/yr }\end{array}$ & $\begin{array}{c}\text { Percent } \\
\text { of total }\end{array}$ \\
\hline NO $_{\mathrm{x}}$ & 24.0 & 22.9 & 95 \\
SO $_{\mathrm{X}}$ & 29.1 & 23.8 & 82 \\
$\mathrm{HC}$ & 24.3 & 8.6 & 35 \\
\hline
\end{tabular}


The summary of 1980 NEDS data shows that the combustion-related emissions of $\mathrm{NO}_{\mathbf{x}}$ and $\mathrm{SO}_{\mathbf{x}}$ represent a large percentage of the total $\mathrm{NO}_{\mathbf{x}}$ and $\mathrm{SO}_{\mathbf{x}}$ emissions in the United States. The hydrocarbon emissions, however, are less than half of the total emissions, which illustrates the magnitude of emissions of HC from other sources.

These data would seem to indicate that coverage of fuel consumed is reasonably complete despite the omissions of fuel-use categories as defined in Section 2.' Also, it suggests that while some fuel-use categories that are omitted may be significant; it does not appear likely that they would have a great impact on the emission estimates that have been generated.

3.5 COMPARISON OF STUDY AREA EMISSIONS VS. NEDS

As a further test of the reasonableness of the results, the estimated emissions of $\mathrm{NO}_{x^{\prime}}, \mathrm{SO}_{x^{\prime}}$ and $\mathrm{HC}$, for the study area and the values from the NEDS are compared in Table 3-14. These data show significant differences that are only partially explainable wilhuil a delailed comparison of the estimation methods used for both data sets. Although such comparisons were beyond the scope of this study, they will be considered in followup work. Although detailed analysis was not possible some explanations are offered for each sector evaluated.

\subsubsection{Transportation Sector}

The transportation emission estimates in this study are low in comparison to NEDS, but they are at least partially explainable 
TABLE 3-14. COMPARISON OF $\mathrm{NO}_{x}$, $\mathrm{SO}_{x}$, AND HC EMISSION ESTIMATES WITH NEDS EMISSIONS IN THE 26-STATE STUDY ARE.A

\begin{tabular}{|c|c|c|c|c|c|c|c|c|c|}
\hline \multirow[b]{3}{*}{ Sector } & \multicolumn{9}{|c|}{ Annual estimated emissions in stugy area, :ons/yr } \\
\hline & \multicolumn{3}{|c|}{$\mathrm{NO}_{\mathrm{x}}$} & \multicolumn{3}{|c|}{$\mathrm{SO}_{\mathrm{x}}$} & \multicolumn{3}{|c|}{ HC } \\
\hline & $\begin{array}{c}\text { PEOCo } \\
\text { data base }\end{array}$ & MEDS & $\begin{array}{l}\text { PEJCC } \div \overline{1} \\
\operatorname{MEDS}(\not)\end{array}$ & $\begin{array}{c}\text { PEOCo } \\
\text { data base }\end{array}$ & NEDS & $\begin{array}{l}\text { PEDCO } \div \\
\text { NEDS (\%) }\end{array}$ & $\begin{array}{c}\text { PECCo } \\
\text { tata base }\end{array}$ & NEOS & $\begin{array}{l}\text { PEDCo } \div \\
\operatorname{MEDS}(x)\end{array}$ \\
\hline Transportation & $4,864,000$ & $5,252,800$ & 93 & 348,000 & 465,800 & .75 & $3,487,000$ & $5,437,100$ & 64 \\
\hline Residential/commercial & 430,000 & 497,600 & 86 & 504,000 & 642,800 & 28 & 34,000 & 36,400 & 93 \\
\hline Ut1lity & $3,856,000$ & $5,082,700$ & $? 7$ & $14,912,000$ & $14,855,400$ & 100 & 26,000 & 42,200 & 62 \\
\hline Industrial & $2,272,000$ & $1,492,100$ & 152 & $5,067,000$ & $2,89 B, 300$ & 175 & 51,000 & 190,800 & 27 \\
\hline Total & $11,462,000$ & $12,325,200$ & 93 & $20,831,000$ & $18,862,300$ & 130 & $3,598.000$ & $5,706,500$ & 63 \\
\hline
\end{tabular}


in terms of the fuel use omitted in this category. The relevant NEDS transportation emission estimates (in tons) are aircraft (NO $\mathrm{N}_{\mathrm{x}}-62,800 \mathrm{,} \mathrm{SO}_{\mathrm{x}} 6,700$, HC $\left.-91,200\right)$ and ships (NO $_{\mathrm{x}}-71,500$, so $_{x} 104,300$, HC $\left.-230,800\right)$. When added to the estimates in this study, the respective results total 95, 99, and 70 percent of the $\mathrm{NO}_{x}, \mathrm{SO}_{x}$, and $\mathrm{HC}$ totals found in NEDS. Thus, only HC emissions are still significantly low. The third omission from this study (pipeline compressors) is not relevant to the comparison because these omissions are classified with industrial emissions in the NEDS system.

\subsubsection{Residential/Commercial}

For the residential and commercial sectors, the study area NO ${ }_{x}$ and $\mathrm{SO}_{\mathrm{x}}$ emissions are 14 and 22 percent lower, respectively, than in the NEDS estimate: This may be due to the small amounts of coal not included in the inventory fuel estimates, although this was not quantified for the 26-state study area. The reasons for these differences will be substantiated in future studies.

\subsubsection{Utility Sector}

The utility sector $\mathrm{NO}_{x}$ emissions in this study are 23 percent lower than NEDS. This could be caused by the fact that $\mathrm{NO}_{\mathbf{x}}$ emissions were not differentiated by firing mechanism as is presumably the case in NEDS. Sulfur oxide emissions agreed very well between the two data sets, but HC emissions in this study were 38 percent lower than in NEDS. No explanation was immediately obvious for this discrepancy. 


\subsubsection{Industrial Sector}

The largest discrepancy is in emissions from the industrial sector, where this study estimated $\mathrm{NO}_{\mathbf{x}}$ and $\mathrm{SO}_{\mathbf{x}}$ emissions that are 52 and 75 percent higher than NEDS estimates. Hydrocarbon emissions in this study were 73 percent lower than in NEDS. The extremely low estimate of HC in this study is not surprising and reflects the low contribution of combustion sources to HC emissions in general.

There are a number of reasons for the $\mathrm{NO}_{\mathrm{x}}$ and $\mathrm{SO}_{\mathrm{x}}$ differences that can be traced to the methodology used to calculate the emissions. First, and apparently the most important; is that the $\mathrm{NO}_{\mathrm{x}}$ and $\mathrm{SO}_{\mathrm{x}}$ emissions from this study have not been reduced to compensate for double counting of emissions already accounted for in the direct-fired portion of the industrial sector. This was discussed previously, and it was estimated that this would reduce $\mathrm{NO}_{\mathrm{X}}$ emissions by about $1,000,000$ tons and $\mathrm{SO}_{\mathrm{x}}$ emissions by $2,473,000$ tons for the total study area. This would brings the totals from this study and NEDS much closer together.

Another difference in methodologies is that NEDS includes some combustion emissions in their "Industrial Process" categories instead of aspect of their industrial combustion emissions. This apparently occurs in a number of major industry groups such as stone, clay and glass, primary and secondary metals, and petroleum. In contrast, this study includes combustion related emissions from process sources. The amount of combustion emissions included in the NEDS industrial process category is not known.

A third difference in methodology is the fact that while this study accounts all industrial fuel as a point or area source, 
NEDS only includes facilities with $>100$ tons/yr of emissions as reported from state agencies. To some extent this is not followed, since there are facilities with emissions $<100$ tons/yr in the NEDS file. The impact on emissions from the absence of these small sources in the NEDS file is not known.

3.6 COMPARISON OF STUDY AREA EMISSIONS VS. WORK GROUP 3B AND THE NATIONAL. ACID PRECIPITATION ASSESSMENT PROGRAM

The emission estimates in this study. were also compared with two other data sets: the U.S./Canadian Work Group 3B Emission Inventory (1980 basis) and the December, 1983 Draft of National Acid Precipitation Assessment Plan (NAPAP) 1980 data base. Table. 3-15 shows a comparison of these three data bases on a state basis for the eastern U.S. The so $_{\mathbf{x}}$ emissions from this study were 7 and 2 percent higher than the respective WG $3 B$ and draft NAPAP data sets. Individual states showed differences in both directions for the three data sets.

In comparison, $\mathrm{NO}_{\mathrm{x}}$ emissions in this study were consistently lower than the draft NAPAP data; but close to the WG3B data on a state basis, and the total No emissions for the 26 states in this study were 1 and 8 percent lower than the WG3B and draft NAPAP data bases, respectively. The low $\mathrm{NO}_{\mathrm{x}}$ emissions (compared with the draft NAPAP data) could be caused by the lack of differentiation of $\mathrm{NO}_{x}$ utility boiler emission factors by firing mechanism in this study. This will be confirmed in future studies. 
TABLE 3-15 COMPARISON OF SO AND NO EMISSIONS FROM CANADIAN WORK GROUP 3B, NATIONAL ACID PRECIPI YATION ASSESSMENT PROGRAM, AND PEDCO DATA BASES

\begin{tabular}{|c|c|c|c|c|c|c|}
\hline \multirow[b]{2}{*}{ state } & \multicolumn{3}{|c|}{ SO $_{x}$ Emissions $\left(10^{3}\right.$ tons $)$} & \multicolumn{3}{|c|}{${ }^{N O}{ }_{x}$ Emissions $\left(10^{3}\right.$ tons $)$} \\
\hline & Wf.3R & NAPAP ' & PFחR:n & Wh.3R & NAPAP & PFOCA \\
\hline $\begin{array}{l}\text { Alabama } \\
\text { Connecticut } \\
\text { District of Columbia } \\
\text { Delaware } \\
\text { Florida } \\
\text { Georgia } \\
\text { Illinois } \\
\text { Indiana } \\
\text { Kentucky } \\
\text { Maine } \\
\text { Maryland } \\
\text { Massachusetts } \\
\text { Michigan } \\
\text { Mississippi } \\
\text { New Hampshire } \\
\text { New Jersey } \\
\text { New York } \\
\text { North Carolina } \\
\text { Ohio } \\
\text { Pennsylvania } \\
\text { Rhode Island } \\
\text { South Carolina } \\
\text { Tennessee } \\
\text { Vermont } \\
\text { Virginia } \\
\text { West Virginia } \\
\text { Wisconsin }\end{array}$ & $\begin{array}{r}759 \\
72 \\
15 \\
109 \\
1,095 \\
840 \\
1,471 \\
2,008 \\
1,121 \\
95 \\
338 \\
344 \\
907 \\
285 \\
93 \\
279 \\
944 \\
602 \\
2,647 \\
2,023 \\
15 \\
326 \\
1,077 \\
7 \\
361 \\
1,088 \\
637\end{array}$ & $\begin{array}{r}841 \\
65 \\
15 \\
114 \\
1,226 \\
891 \\
1,537 \\
1,923 \\
1,175 \\
159 \\
328 \\
354 \\
898 \\
303 \\
111 \\
322 \\
869 \\
668 \\
2,881 \\
1,902 \\
15 \\
359 \\
1,158 \\
99 \\
394 \\
1,148 \\
707\end{array}$ & $\begin{array}{r}882 \\
90 \\
8 \\
99 \\
895 \\
830 \\
1,477 \\
2,544 \\
1,179 \\
58 \\
375 \\
348 \\
829 \\
179 \\
94 \\
292 \\
955 \\
554 \\
3,127 \\
2,542 \\
14 \\
305 \\
1,105 \\
7 \\
274 \\
1,193 \\
577\end{array}$ & $\begin{array}{r}450 \\
134 \\
22 \\
52 \\
648 \\
494 \\
1,005 \\
773 \\
531 \\
59 \\
248 \\
254 \\
690 \\
285 \\
56 \\
406 \\
680 \\
536 \\
1,145 \\
1,038 \\
36 \\
260 \\
517 \\
25 \\
405 \\
452 \\
420\end{array}$ & $\begin{array}{r}523 \\
94 \\
25 \\
67 \\
628 \\
591 \\
1,086 \\
864 \\
604 \\
57 \\
279 \\
261 \\
734 \\
292 \\
60 \\
434 \\
743 \\
571 \\
1,225 \\
1,079 \\
40 \\
304 \\
573 \\
44 \\
409 \\
472 \\
425\end{array}$ & $\begin{array}{r}495 \\
127 \\
17 \\
53 \\
609 \\
485 \\
916 \\
914 \\
458 \\
56 \\
300 \\
240 \\
689 \\
187 \\
44 \\
364 \\
712 \\
486 \\
1,202 \\
1,247 \\
30 \\
243 \\
471 \\
20 \\
349 \\
426 \\
322\end{array}$ \\
\hline Totals & 19,558 & 20,372 & 20,832 & 11,623 & 12,484 & 11,462 \\
\hline
\end{tabular}

* December, 1983 Draft of the NAPAP 1980 Data Base. 
REFERENCES FOR SECTION 3

1. U.S. Department of Energy. State Energy Data Report 1960 Through 1980. Washington, D.C. DOE/EIA-0214(80), 1982.

2. U.S. Department of Commerce. County and City Data Book, 1977. U.S. Bureau of the Census, Washington, D.C. 1978 .

3. U.S. Environmental Protection Agency. The 1980 National Emissions Report - National Emissions Data System. EPA450/4-82-010. 


\section{SECTION 4 \\ ANALYSIS OF POSSIBLE SOURCE IMPACTS}

\subsection{INTRODUCTION}

This section presents the results of the etatistioal analysis of meaourcmento of acid deposition data obtaincd from moni toring stations in each of the three study areas described in. previous sections. The analytical results are compared with the characteristics of each area to draw conclusions regarding the mechanisms influencing wet deposition. The study area boundaries were defined so the stations within each area were relatively near to each other (generally within easily defined wind-direction sectors relative to potential sources) and were impacted by similar precipitation patterns.

\subsubsection{Logic Behind Interpretation of Resuits}

The following logic was used to interpret the results:

1) Similar means and standard deviations between stations determined by the analysis of variance (ANOVA) indicate that the stations are impacted by a well-mixed pollutant mass; thus; the pollutant mass is deposited at a fairly uniform rate throughout an area from the same or possibly different sources.

2) Statistically significant positive intersite correlations indicate that acid deposition rates of pairs of stations increase or decrease together.

3) Failure to observe both of the above results is an indication that the acid deposition rate at one or more stations within the designated geographical area is ". affected by localized sources of emissions. Such 
localized impacts appear to be possible at typical distances of 80 to 240 kilometers (50 to 150 miles) between a monitor and a source or source area, depending on the geological and meteorological characteristics of the area.

\subsubsection{Statistical Procedures Used}

The results are presented for three statistical parameters: 1) means with standard deviations, 2) Pearson correlation coefficients (for intersite correlations), and 3) significance levels for ANOVA with contrast comparisons. The statistical significance of results is based on an a (probability) level equal to 0.10 , or a 90 percent confidence level, which is consistent with the level of sophistication of this analysis. The statistical significance of the intersite correlation coefficients is based on the magnitude of the correlation coefficient and the sample size (i.e. number of pairs of observations). Contrasts in ANOVA were compared to identify significantly different mean deposition rates determined by use of the t-statistic.

\subsubsection{Parameters Analyzed}

Deposition rates for sulfate, nitrate, calcium, and chloride are presented in the text and in the appendix in milligrams of material deposited per square meter of surface area per centimeter of precipitation $\left(\mathrm{mg} / \mathrm{m}^{2}\right.$ per $\mathrm{cm}$ of $\mathrm{ppt}$ ). The results of the statistical analyses performed on the calcium and chloride deposition rates are only given in the appendix. Although not discussed in the text, these analyses indicate that deposition rates for calcium are partly a function of industrial sources in the area. The chloride results follow no apparent trend. 
The statistical results of sulfate and nitrate analyses were combined with other types of information, including dispersion factors (physical features), meteorological factors, and emission patterns, to reach the conclusions presented in this study. Each area is discussed separately in the balance of this section.

\section{2 NEW YORK AREA - HUDSON RIVER VALLEY}

\subsubsection{Station Locations}

This study area contains three NADP stations. Figure 4-1 shows the general study area and the location of deposition stations. Table 4-1 presents additional pertinent information for each station. All of the NADP stations are located along the Hudson River, north of New York City 4.2.2 Physical Features of the Study Area

The study area, which encompasses all of the Hudson River Valley, extends from New York City in the south to the Adirondack Mountains in the north. The Catskill Mountains lie to the west of the the southern part of the study area. The elevation of the southern half of the Hudson River, from New York City to Albany, is near sea level. Elevations of the monitoring stations range from 200 meters (660 feet) above mean sea level (MSL) at the Columbia station, to 520 meters $(1700$ feet) above MSL at the Essex station. The station in Orange County [elevation 300 meters (985 feet)] overlooks the Hudson Valley where the river divides. 


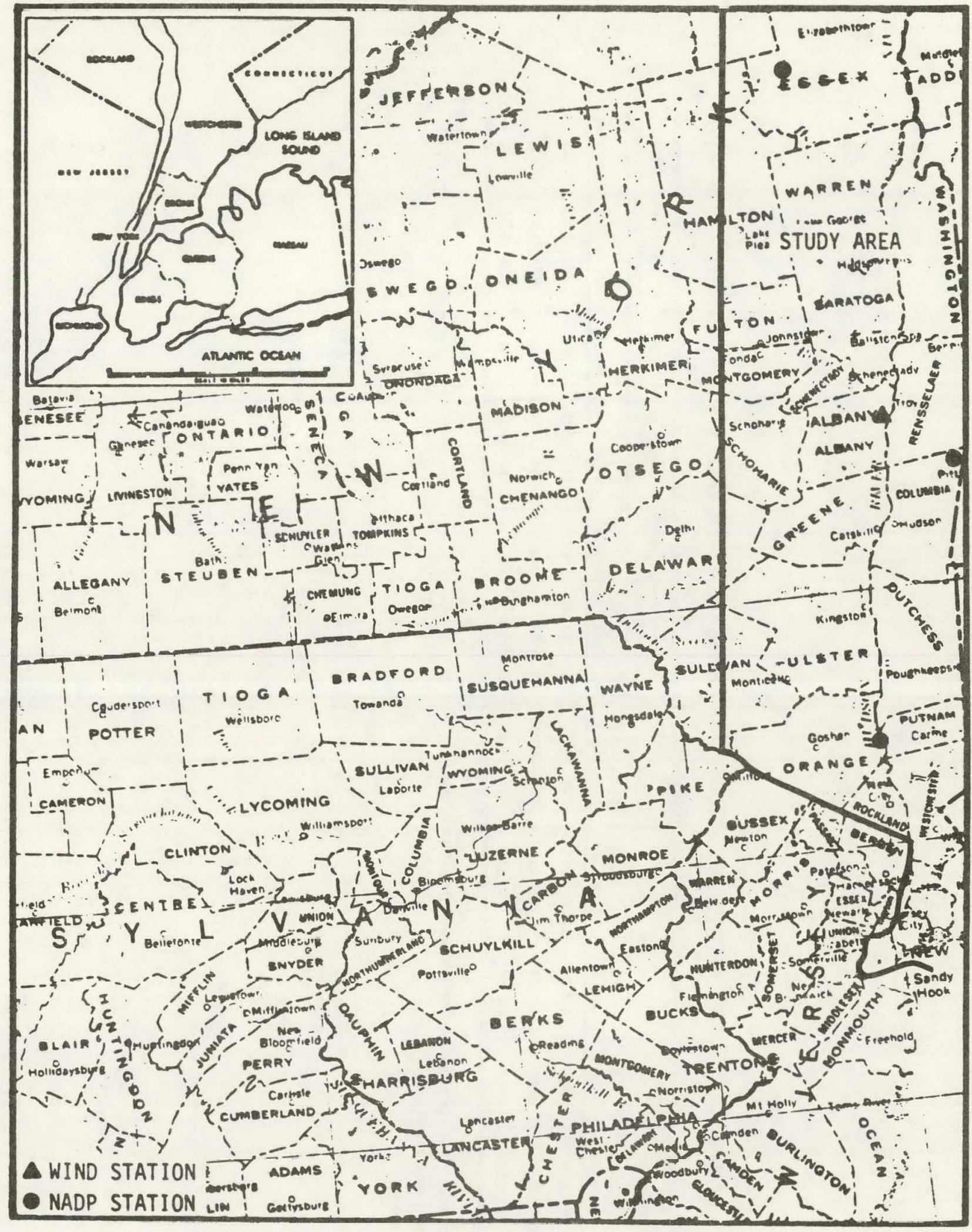

Figure 4-1. Location of monitoring stations in the New York study area. 
TABLE 4-1. ACID DEPOSITION STATIONS IN THE HUDSON RIVER VALLEY AREA

\begin{tabular}{|c|c|c|c|c|c|c|c|c|c|c|c|}
\hline \multirow[b]{2}{*}{ County } & \multirow[b]{2}{*}{$\begin{array}{r}\text { Station } \\
\text { number }\end{array}$} & \multirow[b]{2}{*}{ Metwork } & \multirow[b]{2}{*}{ Latitude } & \multirow[b]{2}{*}{ Longltude } & \multirow[b]{2}{*}{$\begin{array}{c}\text { Elevation, } \\
\text { ( } \mathrm{ft} \text { ) }\end{array}$} & \multicolumn{2}{|c|}{$\begin{array}{l}\text { Locat ion relatjue } \\
\text { to Manhattan }\end{array}$} & \multicolumn{2}{|c|}{$\begin{array}{c}\text { Locat ilon relag̨ive } \\
\text { tc A"buny }\end{array}$} & \multicolumn{2}{|c|}{$\begin{array}{l}\text { Location relative } \\
\text { to SW cormer of Onto }\end{array}$} \\
\hline & & & & & & $\begin{array}{l}\text { Distance, } \\
\mathrm{km} \text { (miles) }\end{array}$ & Direction & $\begin{array}{l}\text { Distance, } \\
\mathrm{km} \text { (miles) }\end{array}$ & Direction & $\begin{array}{l}\text { Distance, } \\
k \text { (milles) }\end{array}$ & Direction \\
\hline Orange & 335140 & MEOP & $41^{\circ} 21^{\prime}$ & $74^{\circ} 02^{\prime}$ & $300 \quad(985)$ & 74 (46) & N & $.45 \quad(90)$ & $s$ & $949(590)$ & EME \\
\hline Columbia & 331220 & MADP & $42^{\circ} 07^{\prime}$ & $73^{\circ} 31^{\circ}$ & $201 \quad(660)$ & $161(100)$ & M⿻上 & $64(40)$ & SSE & $1014(630)$ & EWE \\
\hline Essex & 332020 & MAOP & $44^{\circ} 00^{\prime}$ & $74^{\circ} 13^{\prime}$ & $5 ? 1(1710)$ & $362(225)$ & ต & $: 45 \quad(90)$ & men & $1030(640)$ & WE \\
\hline
\end{tabular}

- Approximate elevation above sea level based on topographic maps.

Southern wost point.

c city center. 
The Columbia station is located in an area where the valley walls increase rapidly in elevation to a maximum of 790 meters (2600 feet). Albany lies to the northwest of Columbia County at the confluence of the Mohawk and Hudson Rivers. The Mohawk River, which flows from the Rome/Utica area (Oneida County) to Albany, forms the southern edge of the Adirondack Region. The average elevation of the Mohawk River Valley is 150 to 180 meters (500 to 600 feet).

The station in Essex County is approximately 40 kilometers (25 miles) west of the Champlain Valley, very near the origin of the Hudson River. The elevation at this station $[520$ meters $(1710 \mathrm{ft})]$ is about one-third the maximum elevation of the Adirondack Mountains.

\subsubsection{Meteorological Factors}

Local and mesoscale transport winds affect the general flow of air masses in the study area. In the Hudson River Valley, an up-valley air flow from the major metropolitan area of New York City toward the Albany area is suspected of causing some transport of pollutanls from sources of emissions located in the New York City metropolitan area northward up the Hudson River Valley. From May through October, the general wind flow is from the south (New York City) and southwest (Allentown, Pennsylvania), and most precipitation occurs during thunderstorms of intense duration. Conversely, in the winter and early spring, winds are generally from the west and northwest; precipitation in this period occurs during widespread storms that may persist for several days. 
Figure 4-2 shows this seasonal shift in wind directions for several wind stations and also shows the potential for transport of emissions from the New York City area up the Hudson River Valley during the summer months.

Data on the transport of pollutants in the mixing layer are also helpful in analyzing possible source impacts. Pollutants that are released into the atmosphere are dispersed and transported throughout the mixed layer of the atmosphere. The mixing layer is generally defined as the height above the surface through which vertical atmospheric mixing occurs. Below this height, pollutants are expected to mix quite well; above this height, only limited mixing occurs. On the average, mixing heights and windspeeds are higher during precipitation events than when no precipitation is occurring.

An analysis of the winds at $900 \mathrm{mb} 11000 \mathrm{~m}(3280$ feet.) in the U.S. Standard Atmosphere] gives an indication of the difference between surface measurements and measurements taken higher up within the mixing layer. The latter are believed to be the ones most likely to transport pollutants in the mixed layer. Table 4-2 presents the frequency of occurrence of winds from 180 \pm 22.5 degrees for both surface and average $900-\mathrm{mb}$ winds at the J.F.K. International Airport. The data show that southerly surface winds occur more frequently during spring and summer than during autumn and winter. At the $900-\mathrm{mb}$ level southerly winds occur more frequently during autumn than in any other season. 


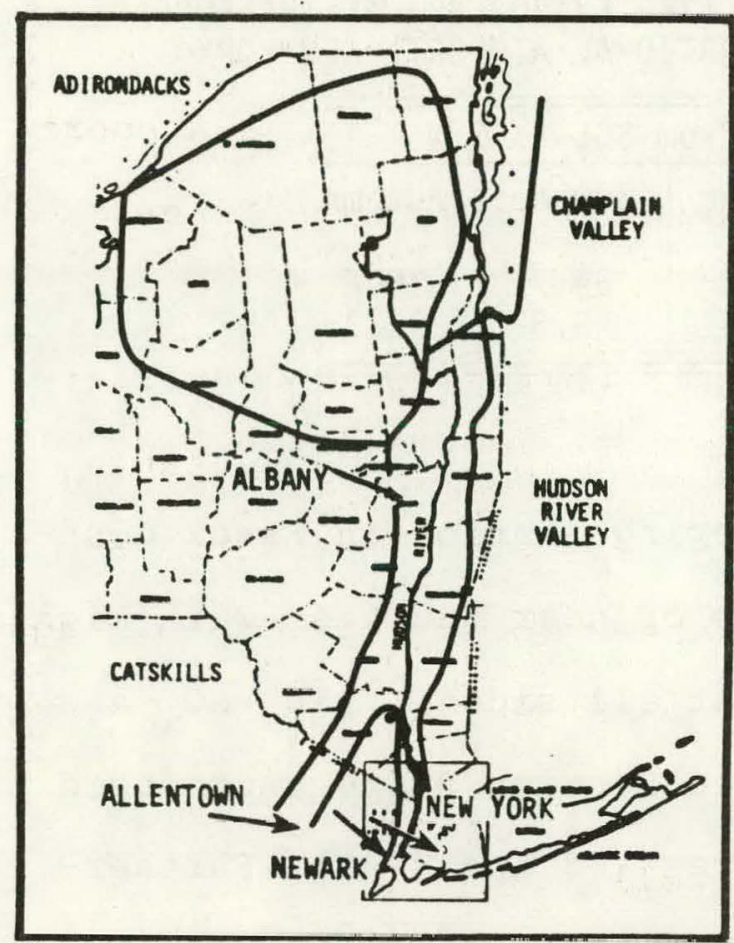

Winter

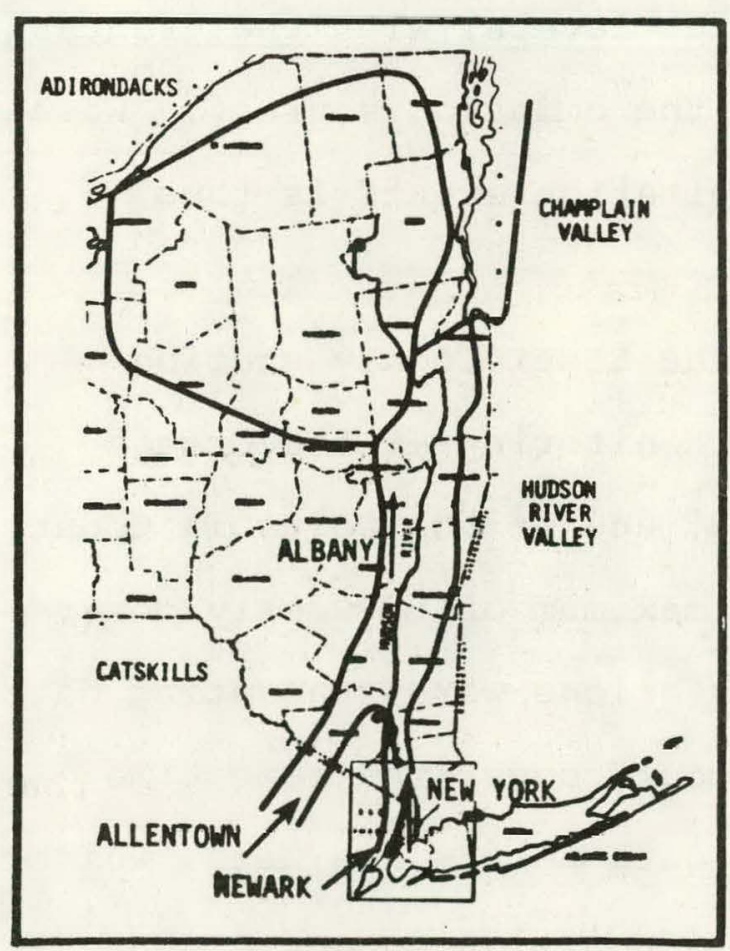

Summer

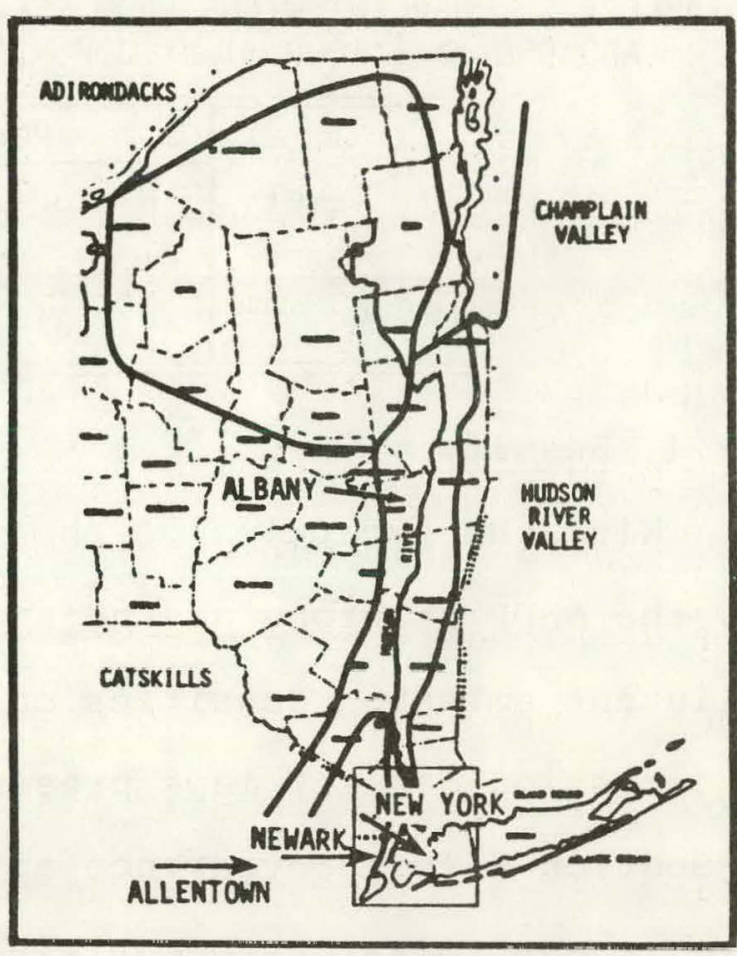

Spring

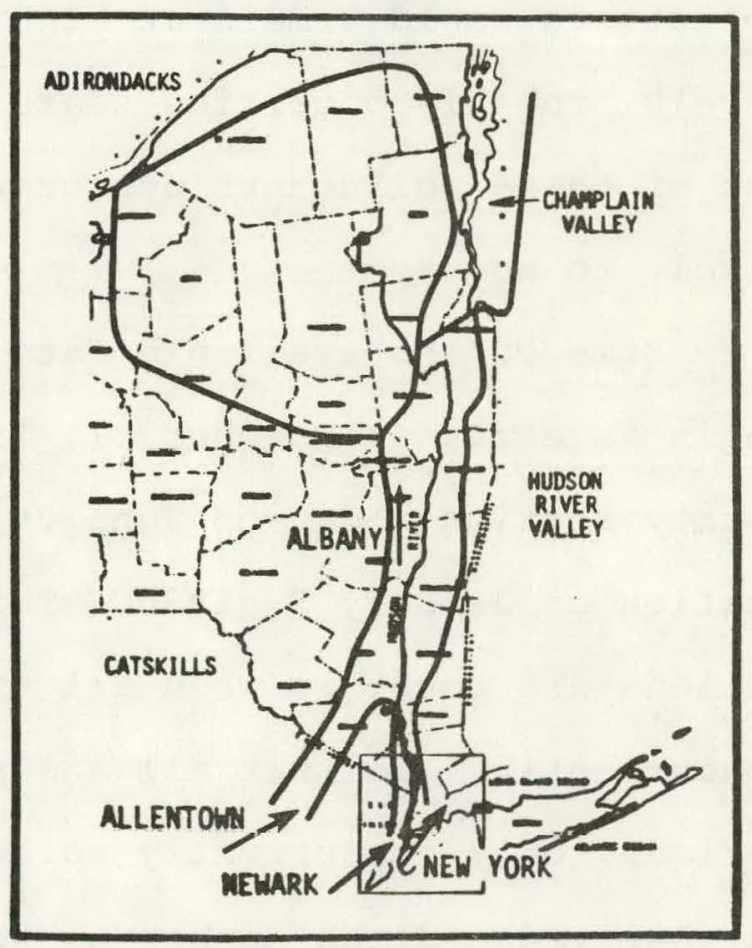

Autumn

Figure 4-2. Winter, spring, summer, and autumn average prevailing wind directions. 
TABLE 4-2. PERCENT WINDS FROM SSE-S-SSW $\left(157.5^{\circ}-202.5^{\circ}\right)$ AT THE SURFACE AND $900 \mathrm{mb}(\sim 1000 \mathrm{~m})$ at J.F.K. INTERNATIONAL AIRPORT, NEW YORK

\begin{tabular}{l|c|c|c|c}
\hline \hline \multirow{2}{*}{ Wind leve1 } & \multicolumn{4}{|c}{ Percent from SSE to SSW } \\
\cline { 2 - 5 } & Winter & Spring & Summer & Autumn \\
Surface & 11.1 & 27.2 & 35.7 & 18.4 \\
$900 \mathrm{mb}$ & 7.3 & 9.4 & 8.3 & 12.3 \\
\hline \hline
\end{tabular}

\subsubsection{Results}

With the exception of the monitoring station in Essex County, the NADP stations are adjacent to or near counties with high pollutant emission densities on almost all sides. (The $\mathrm{SO}_{\mathrm{x}}$ and $\mathrm{NO}_{\mathrm{x}}$ emission density maps presented in section 3 are reproduced in Section 4 for convenience as Figures 4-3 and 4-4.) Furthermore, these emissions occur within the confines of the Hudson River Valley or its extensions. When mixed in the valley, these pollutants would remain at high ambient levels, with the greatest levels probably occurring nearest to the emission sources. Washout of these pollutants during precipitation events is thus Likely to occur.

Some of the available data for the Essex County station begin as early as October 31, 1978. Monitoring at the Orange County station began on June 26, 1979, and at the Columbia County station on January 2, 1980. Thus, a maximum of 52 weekly observations are possible when all three stations were generating data concurrently. So that all analyses would cover the same time periods, only concurrently collected data points are used, which further reduced the number of weekly deposition measurements available for analysis. 


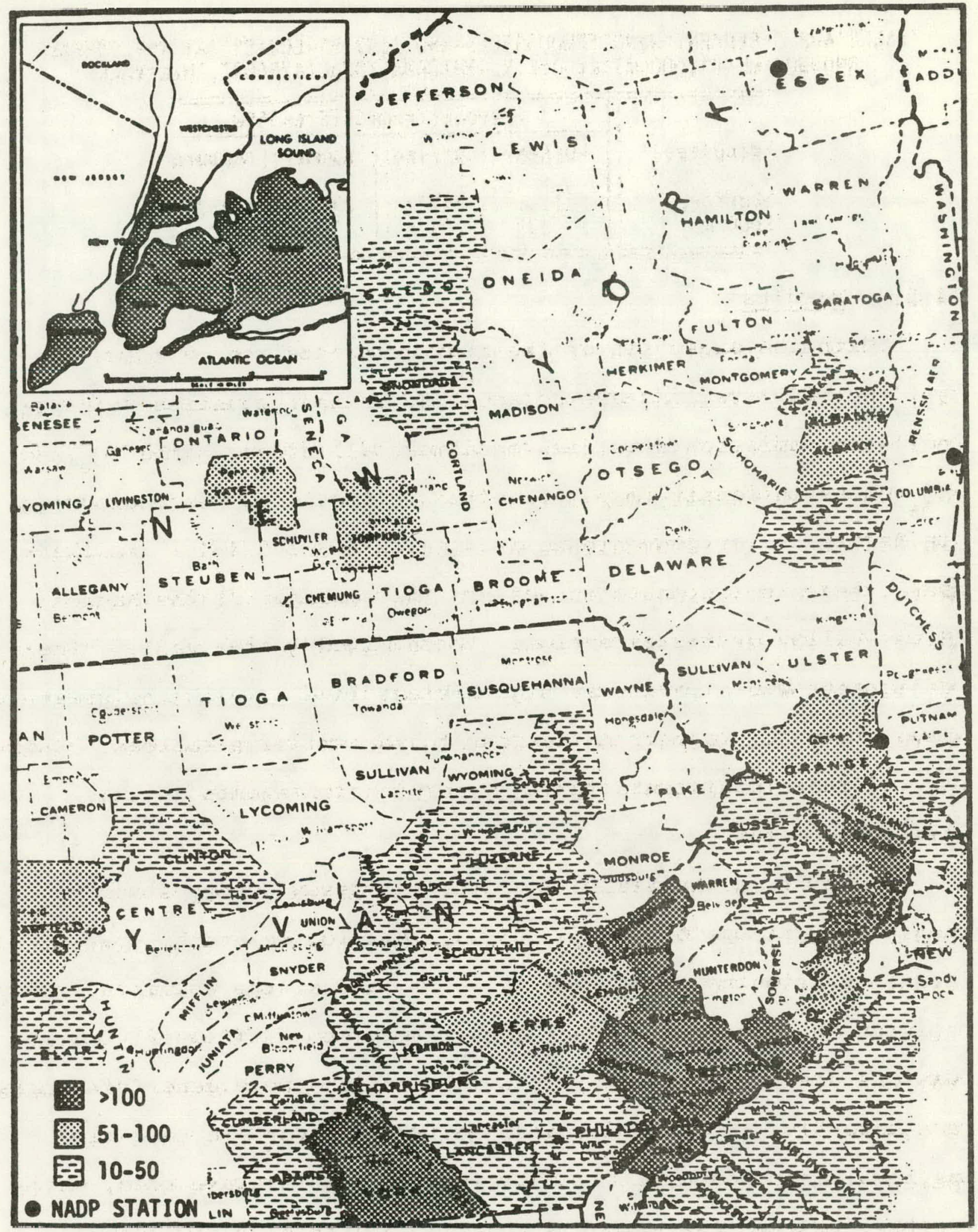

Figure 4-3. Emission density ranges of $\mathrm{SO}_{\mathrm{x}}$ (tons $/ \mathrm{mi}^{2}$ per $\mathrm{yr}$ ) for all sectors combined in the New York Hudson River Valley study area. 


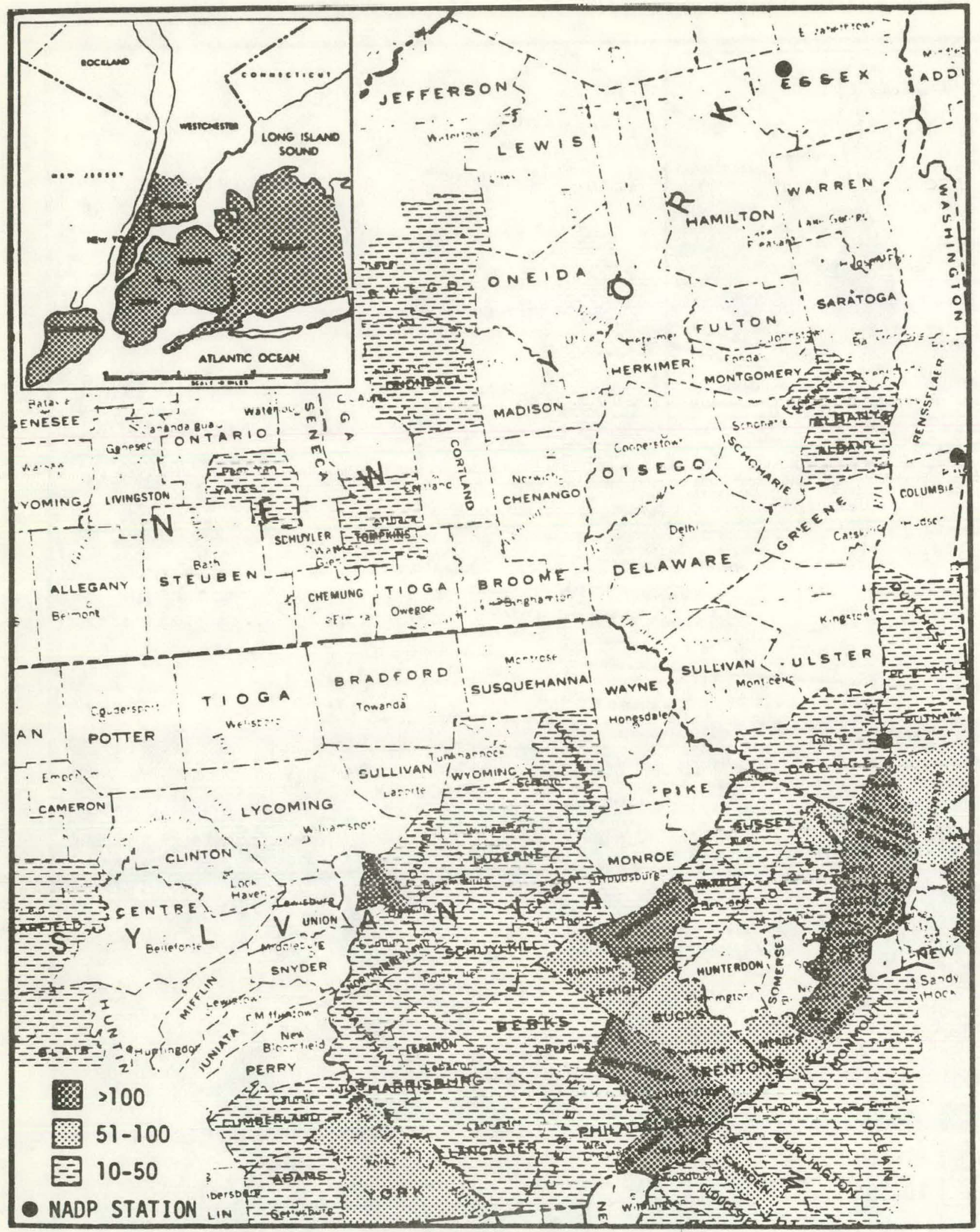

Figure 4-4. Emission density ranges of $\mathrm{NO}$ (tons $/ \mathrm{yr} / \mathrm{mi}^{2}$ ) for all sectors combined in the New York Hudson River Valley study area. 
Twenty-nine data points were used in this analysis. Grouping the data by wind direction produces 11 data points when winds are from the northwest at Albany and 18 points when winds are from the south at Albany. The distribution of data by month is given in Table 4-3. The three data sets analyzed consisted of sets containing all data and two subsets of the data based on the prevailing wind directions at Albany. One data point was deleted from all three stations as an outlier. The measured deposition rates of this data point, generated on April 15, 1980, were more than four standard deviations away from the mean at each station (the range was from 36.9 for nitrate and 39.7 for sulfate at Essex to 304.2 for nitrate and 264.8 for sulfate at orangel.

\section{Sulfate Results--}

The input data and complete statistical results are provided in the appendix. Table 4-4 summarizes these results for all pollutants. The highest individual average value occurred at the Columbia station while the lowest individual average value occurred at the Essex station. All three stations display similar seasonal deposition rate patterns and all show maximum rates when winds are from the south as opposed to the west-northwest: Columbia, 47.4 vs. 34.0 ; Orange, 43.4 vs. 26.0 ; and Essex, 33.5 vs. 19.3. Intersite correlation coefficients $(r)$ are also summarized in Table 4-4. As stated earlier, all tests of significance are at the 0.10 level. The correlations observed range from 0.00 between Essex and orange during west-northwest winds up to 0.63 
TABLE 4-3. NUMBER OF CONCURRENT WEEKLY DATA POINTS

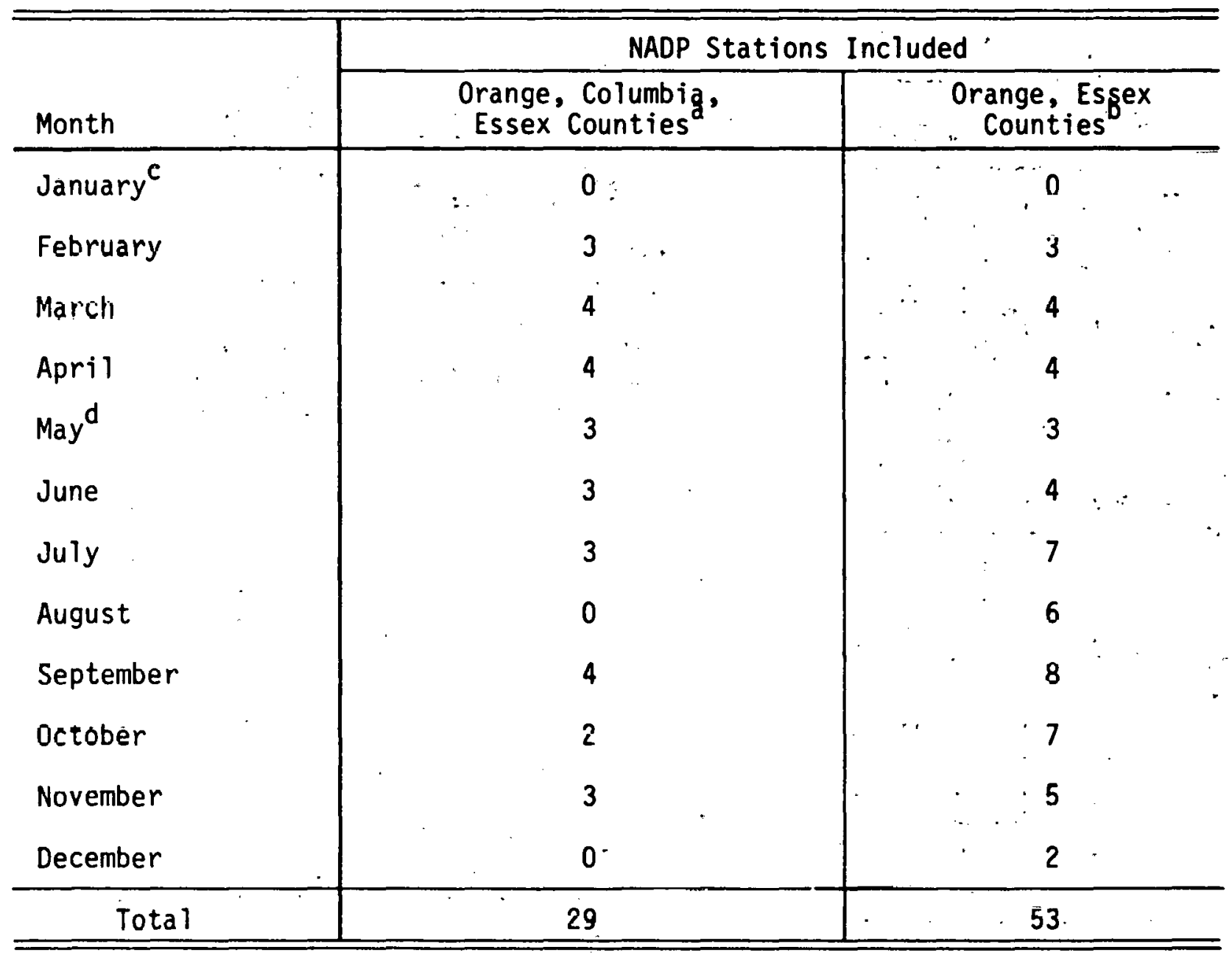

a January 1, 1980 to December 31, 1980.

b June 26, 1979 to December $31, .1980$.

c Surface winds from the WNW from January to April at Albany.

d Surface winds from the $S$ from May to December at Albany. 
TABLE 4-4、 SUMMARY OF NEW YORK RESULTS

A. Average Deposition Rates and Standard Deviations, $\mathrm{mg} / \mathrm{m}^{2} / \mathrm{cm}$ of ppt

\begin{tabular}{|c|c|c|c|c|c|c|c|c|c|c|c|c|}
\hline \multirow[b]{3}{*}{ Station } & \multicolumn{4}{|c|}{ All concurrent observations } & \multicolumn{4}{|c|}{$\begin{array}{l}\text { Surface winds } \\
\text { from south at Albany }\end{array}$} & \multicolumn{4}{|c|}{$\begin{array}{l}\text { Surface winds from } \\
\text { west-northwest at Albany }\end{array}$} \\
\hline & \multicolumn{2}{|c|}{$\mathrm{SO}_{4}^{-2}$} & \multicolumn{2}{|c|}{$\mathrm{NO}_{3}^{-}$} & \multicolumn{2}{|c|}{$\mathrm{SO}_{4}^{-2}$} & \multicolumn{2}{|c|}{$\mathrm{NO}_{3}^{-}$} & \multicolumn{2}{|c|}{$\mathrm{SO}_{4}^{-2}$} & \multicolumn{2}{|c|}{$\mathrm{NO}_{3}$} \\
\hline & $\bar{x}$ & .5 & $\bar{x}$ & $\mathbf{s}$ & $\bar{x}$ & s & $\bar{x}$ & s & $\bar{x}$ & $\mathbf{s}$ & $\bar{x}$ & s \\
\hline Orange & 36.8 & 20.8 & 25.4 & 15.5 & 43.4 & 21.1 & 26.7 & 13.0 & 26.0 & 15.8 & 23.2 & 19.5 \\
\hline Columbia & 42.3 & 30.6 & 29.4 & 24.1 & 47.4 & 26.9 & 30.3 & 17.3 & 34.0 & 35.6 & 27.8 & 33.6 \\
\hline Essex & 28.1 & 13.7 & 23.1 & 10.8 & 33.5 & 11.9 & 21.3 & 7.8 & 19.3 & 13.7 & 26.0 & 14.4. \\
\hline
\end{tabular}

$n=29$

$n=18$

C $n \cdot 11$

B. Intersite Correlation Coeffictents

Sulfate

\begin{tabular}{l|r|l}
\multicolumn{2}{|c|}{ Sulfate } \\
\hline & Columbia & Essex \\
\hline Orange & $0.76^{\mathrm{a}}$ & $0.55^{\mathrm{a}, \mathrm{b}}$ \\
Columbia & & $0.46^{\mathrm{a}, \mathrm{b}}$ \\
\hline & Columbia & Essex \\
\hline Orange & $0.70^{\mathrm{a}}$ & $0.63^{\mathrm{a}, \mathrm{b}}$ \\
Columbia & & $0.63^{\mathrm{a}, \mathrm{b}}$ \\
\hline & Columbia & Essex \\
\hline Orange & $0.92^{\mathrm{a}}$ & 0.00 \\
Columbla & & 0.15 \\
\hline \hline
\end{tabular}

All concurrent observations

- Significant at 90 percent level.

b AMOVA results are significant for this pair of stations.

South winds at Albany

Mest-northwest winds at Albany

\begin{tabular}{|c|c|c|}
\hline \multicolumn{3}{|c|}{ Nitrate } \\
\hline & Columbla & Essex \\
\hline \multirow{3}{*}{$\begin{array}{l}\text { Orange } \\
\text { Columbla }\end{array}$} & $0.43^{a}$ & $0.47^{\mathrm{a}}$ \\
\hline & & 0.04 \\
\hline & Columbla & Essex \\
\hline \multirow{3}{*}{$\begin{array}{l}\text { Orange } \\
\text { Columb ia }\end{array}$} & $0.59^{\circ}$ & $0.46^{\circ}$ \\
\hline & & $0.29^{b}$ \\
\hline & Columbia & Essex \\
\hline Orange & 0.34 & $0.54^{\circ}$ \\
\hline Columbia & & -0.18 \\
\hline
\end{tabular}


between Essex and both other stations during south winds. Correlations are generally less when the entire data set is used than when the subsets are used. Low correlations during west-northwest winds indicate that the impact on the Essex station is different from that on the other two stations. The significant correlations during south winds indicate that the impact on the Essex station is similar to that on the other two stations. The high correlation between the Orange and Columbia stations was expected because of the proximity of the two stations and the likelihood of impact by similiar air masses.

An ANOVA performed on these same data sets produced the results as shown in Table 4-4. Most notable is the significant difference in the values at the Essex station during winds from the south compared with those at the other two stations; when the winds were from the west-northwest, the values were not significantly different. At all times, the Eeccu data vary muils less than lijuse for the other two stations, as evidenced by the low standard deviations in the data sets at Essex.

Nibrále Reeults--

Results for $\mathrm{NO}_{3}^{-}$deposition rates are also summarized in Table 4-4. The two stations closest to the New York City area display maximum mean $\mathrm{NO}_{3}^{-}$deposition rates $(30.3$ and 26.7$)$ and minimum standard deviations $(17.3$ and 13.0$)$ when winds are from the south. The mean and standard deviation for the Columbia station $(\bar{x}=27.8, s=33.6)$ are greater than those for the Orange station $(\bar{x}=23.2, s=19.5)$ during west-northwest winds because 
of the influence of emission sources near Albany. Contrary to the $\mathrm{SO}_{4}^{-2}$ results, however, $\mathrm{NO}_{3}^{-}$results at the two stations are not significantly correlated during the west-northwest wind pattern $(r=0.34)$. None of the results at Columbia correlate well with those at the Essex station $(r=0.04,0.29$, and -0.18$)$. Therefore, a source near the Columbia station strongly influences its variation, but that source has little impact on the other stations. The ANOVA results for $\mathrm{NO}_{3}{ }^{-}$do not reveal any significant differences between the deposition rates at the 90 percent confidence level for any comparison except the Columbia/Essex pair when winds are from the south (mean difference equals 9.0). These results indicate that although similar source types contribute to the deposition at each station, a unique source or source area that influences the deposition at the Columbia station has a less-pronounced effect on the other two stations. This points to the New York area as a contributing source when southern winds prevail (Columbia mean $=30.3$ ) and the Albany area as a contributing source during west-northwest winds (mean $=27.8$ ). 4.2.5 Discussion of New York Results

Based on the statistical results presented in the text and in Appendix $A$ and the discussion of the factors affecting the deposition of material in the Hudson Valley, the following conclusions and interpretations are offered:

Sulfates--

Contributing sources. (or source areas) at all three stations analyzed during periods of southern wind flow are concluded to be located in the New York City area, 
or even further south in New Jersey. The results of the statistical analyses confirm this in several ways: a) the Columbia station has a higher mean value and a larger standard deviation than any other station, which indicates the impact of a strong source area subject to fluctuations in emission rates or pollutant delivery into the valley; b) the means at both the Columbia and Orange stations are significantly different from those at the Essex station during south winds, but not during west-northwest winds (Columbia and Orange are never significantly different from one another); c) even given the significant difference in the mean at the Essex station, results at Essex significantly correlate with those at orange and Culumbla during south winds, but do not correlate at all when winds are from the western dircction, which lndicates the same source impart in the sumimer, but at a much lesser impact rate. It is apparent that the same source area is delivering pollutants from south to north in the Hudson Valley and that the source is continually depleted as the pollutants travel farther from New York City. Finally, all stations exhibit a higher mean deposition rate when winds originate from the direction of New York City rather than from the west, where clearly defined source areas are less prevalent.

- The contributing source iocation is not the same for all three stations during west-northwest wind periods, and is not the same as when the winds are from the south. The source areas impacting the Columbia and Orange stations are west of these stations and include the Albany area. Some unknown, but different area (possibly Canada) impacts deposition at the Essex station. This is substantiated by the same results cited above, i.e., lack of a significant correlation between stations in the southern part of the area and the northern part, but deposition rates that are not significantly different.

Nitrates--

- Sources contributing to nitrate deposition have a greater impact on the columbia station than on any other station in the study area, but there is some question as to whether the same source areas impact all three stations during southern wind flows. As in the case of sulfate, the nitrate deposition at orange and Columbia is never significantly different (although the mean at Columbia is greater than at orange), and the two stations are always significantly correlated. Also as for sulfate, the Columbia nitrate mean is significantly different from the Essex mean during southern 
winds, but not during western winds. The two stations, however, are never significantly correlated with one another, which indicates the possibility of different sources of impact. In contrast to this, the orange and Essex stations, although never significantly different, are always significantly correlated, which implies that the same source is impacting both stations in a similar manner. The only definite assessment of contributing source areas that can be ascertained from the results is that the Columbia monitor is impacted by nitrate sources south of the station (most likely motor vehicles) during southern wind flows and from the Albany area during west-northwest wind flows.

\subsection{OHIO/PENNSYLVANIA AREA}

\subsubsection{Station Locations}

As shown in Figure 4-5, four NADP stations are located within this study area. Table 4-5 presents pertinent information on each station. All stations except the one in Huntingdon County are located within the geographic area defined as the Appalachian Plateau, which is characterized by increasing elevations from west to east and rolling hills with steeper gradients on the eastern side. The station in Huntingdon County is in a valley and ridge area characterized by low, even-crested ridges that predominate over the valley areas. This ridge and valley area is separated from the Appalachian Plateau by a section of the Allegheny Mountains.

The station elevations given in Table 4-5 show the effect of the gently rising land areas at the first three stations. The elevations also show that the Huntingdon station is located in a valley area [approximately 210 meters (700 feet) lower than surrounding areas]. 


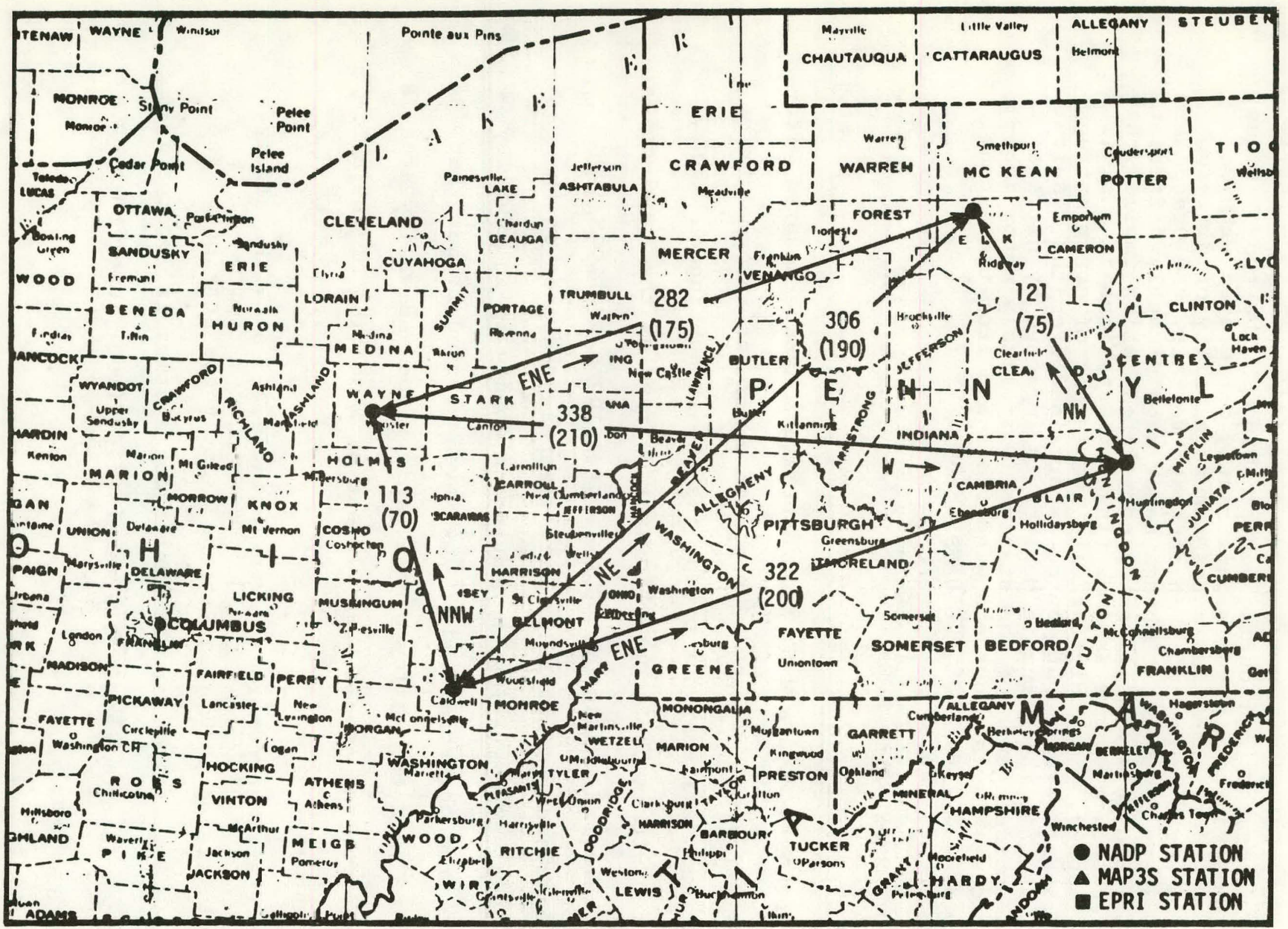

Figure 4-5. Locations of deposition monitoring stations in Ohio/Pennsylvania study area, and separation distances in kilometers (miles). 
TABLE 4-5. NADP STATIONS IN THE OHIO/PENNSYLVANIA STUDY AREA

\begin{tabular}{|c|c|c|c|c|c|c|c|c|}
\hline \multirow[b]{2}{*}{ County } & \multirow[b]{2}{*}{$\begin{array}{l}\text { Station } \\
\text { number }\end{array}$} & \multirow[b]{2}{*}{ Latitude } & \multirow[b]{2}{*}{ Longitude } & \multirow[b]{2}{*}{$\begin{array}{l}\text { Elevation, } \\
m(\mathrm{ft})^{\mathrm{a}}\end{array}$} & \multicolumn{2}{|c|}{$\begin{array}{l}\text { Location relative } \\
\text { to SW corner of Ohio }\end{array}$} & \multicolumn{2}{|c|}{$\begin{array}{l}\text { Location } \\
\text { relative to Pittsburgh } \\
\text { b }\end{array}$} \\
\hline & & & & & $\begin{array}{l}\text { Distance, } \\
\mathrm{km} \text { (miles) }\end{array}$ & Direction & $\begin{array}{l}\text { Distance, } \\
\mathrm{km} \text { (miles) }\end{array}$ & Direction \\
\hline Noble & 364900 & $39^{\circ} 47^{\prime}$ & $81^{\circ} 31^{\prime}$ & $274 \quad(900)$ & $290(180)$ & ENE & 153 (95) & WSW \\
\hline Wayne & 367160 & $40^{\circ} 46^{\prime}$ & $81^{\circ} 56^{\prime}$ & $312(1025)$ & $306(190)$ & NE & 169 (105) & WNW \\
\hline Elk & 392940 & $41^{\circ} 33^{\prime}$ & $78^{\circ} 46^{\prime}$ & $610(2000)$ & $595(370)$ & ENE & $161(100)$ & $\mathrm{NE}$ \\
\hline Huntingdon & 394200 & $40^{\circ} 39^{\prime}$ & $77^{\circ} 56^{\prime}$ & $274 \quad(900)$ & $611(380)$ & ENE & 177 (110) & $E$ \\
\hline
\end{tabular}

a Approximate elevation above mean sea level.

b City center.

c Approximate coordinates. 
With the exception of the Wayne County station, all stations are located east-northeast of southwestern Ohio. The stations are essentially equidistant from Pittsburgh in various directions, and the two stations in ohio are about the same distance apart as the two stations in Pennsylvania.

\subsubsection{Meteorological Factors}

Local and mesoscale transport winds in the study area generally affect the flow and dispersion of air pollutants. The most predominant transport mechanisms are the lasye migratory pressure systems that move generally from the southwest to the northeast. Local effects due to Lake Erie also account for some transport. Cold polar outbreaks coupled with Lake Erie moisture are a regular winter feature of the area, along with the associated snow, cloud cover, and gusty winds. The highly changeable weather is also influenced by air masses heavily laden with moisture and heat from the Gulf of Mexico; thus, the area is subject to moderating temperatures and wet conditions throughout the year.

Distribution of precipitation over the area is generally constant throughout the year; slightly greater amounts occur in the spring and early summer. The frequent influence of highpressure systems and the accompanying stagnating conditions are often associated with the buildup of airborne pollutants over a wide area.

The surface wind directions at several locations in the study area are shown in Figure 4-6 for several representative months. As is seen in this figure, in late spring and summer the 

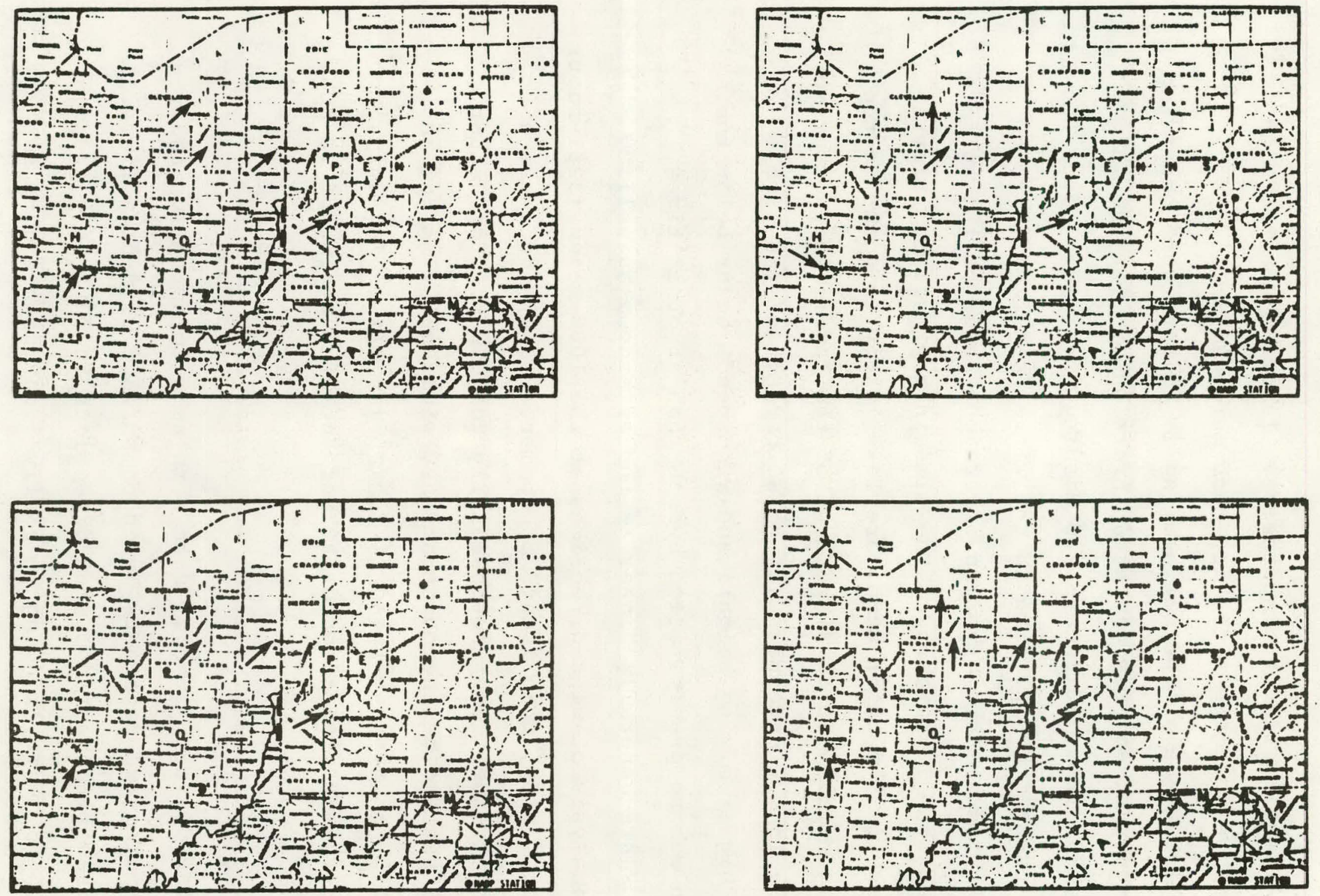

Figure 4-6. Prevailing wind directions in the Ohio/Pennsylvania study area for January, April, July, and October. 
winds are usually from the southwest. In other months, wind directions between the sites are much more variable.

The influence of thermal heating is evident when observing the frequency of surface elevated inversions. Over the ohio/Pennsylvania areas, surface-based morning inversions occur about 30 to 40 percent of the time in the winter and from 70 to 80 percent in the summer. Evening inversions based at the surface occur less than 10 percent of the time in any season. Elevated inversions, on the other hand, are less likely to occur in the morning (generally 20 to 40 percent of the time); they occur more frequently in the afternoon (40 to 60 percent of the time). Somewhat higher mixing heights and windspeeds occur below the inversion during precipitation events than at other times. Windspeeds are generally higher in the afternoon as well.

An analysis of wind directions at the 1000-meter (3281-foot) level over Dayton, Ohio (Dept. of Commerce 1960) indicates a strong and frequent west-southwesterly component. For January, during 37 percent of the observations, winds are from the westsouthwest at an average speed of $23 \mathrm{mph}(10 \mathrm{~m} / \mathrm{s})$. For July, winds are from the same sector 43 percent of the time at $20 \mathrm{mph}$ $(9 \mathrm{~m} / \mathrm{s})$.

\subsubsection{Results}

As in New York, several data sets were selected for analysis, including two data sets based on surface wind directions. Because prevailing surface wind directions in ohio vary greatly from month to month, finding an easily identifiable data set 
based on wind direction is difficult. Therefore, an analysis was also made of two data sets based on the heating season (the period from November through April) and the nonheating season (May through october).

The stations in this study area are some of the first NADP. stations to become operational. The Elk County station first became operational on July"18, 1978, but did not begin to obtain wet-only data on a consistent basis until May 1979. The stations in Noble and Wayne Counties began operating on September 26, 1978, and have generated fairly consistent wet-only samples since that time. The station in Huntingdon County, which began operating on April 25, 1979, also has generated consistent samples from the beginning. A maximum of 89 weekly data points would be possible when all four stations were generating data. Because of erratic collection at the Elk County station, however, the stations did not generate data concurrently until May 15, 1979; thus, only 54 weekly data points were available. Table 4-6 lists these available data points by month.

Table 4-7 presents averages and standard deviations for the $\mathrm{SO}_{4}^{-2}$ and $\mathrm{NO}_{3}^{-}$data sorted according to wind direction. No significant differences exist between any of the stations when the data are grouped by wind direction for $\mathrm{SO}_{4}{ }^{-2}$ or $\mathrm{NO}_{3}{ }^{-}$: Results of all stations are significantly correlated with one another at all times, except the $\mathrm{so}_{4}^{-2}$ results for the wayne County and Noble County stations for $\mathrm{so}_{4}^{-2}$ when winds are from the south. This analysis shows a similarity among all stations 
TABLE 4-6. NUMBER OF CONCURRENT WEEKLY DATA POINTS AVAILABLE IN OHIO/PENNSYLVANIA

\begin{tabular}{|c|c|c|}
\hline Month & $\begin{array}{l}\text { Data points } \\
\text { available }\end{array}$ & Data groups ${ }^{a}$ \\
\hline $\begin{array}{l}\text { January } \\
\text { Fehrilary } \\
\text { March } \\
\text { April } \\
\text { May } \\
\text { June } \\
\text { July } \\
\text { August } \\
\text { September } \\
\text { October } \\
\text { November } \\
\text { December }\end{array}$ & $\begin{array}{l}0 \\
4 \\
4 \\
3 \\
6 \\
6 \\
6 \\
7 \\
6 \\
7 \\
3 \\
2\end{array}$ & $\begin{array}{l}2,3 \\
2,3 \\
2,3 \\
2,3 \\
2,4 \\
1,4 \\
2,4 \\
2,4 \\
1,4 \\
1,4 b \\
1,3 \\
1,3\end{array}$ \\
\hline Total & 54 & \\
\hline
\end{tabular}

a Group 1 - Winds from the south at Akron, Ohio; Total $=24$. Group 2 - Winds not from the south at Akron, Ohio; Total $=30$. Group 3 - Heating season; Total $=18$. Group 4 - Nonheating season; Total $=36$.

b Two data points started on last day of October included in Group 3 Heating season. 
TABLE 4-7. DEPOSITION RATES AI NADP STATIONS IN OHIO/PENNSYLVANIA $\left(\mathrm{mg} / \mathrm{m}^{2} / \mathrm{cm}\right.$ of $\left.\mathrm{ppt}\right)$

\begin{tabular}{l|c|c|c|c|c|c|c|c}
\hline \hline \multirow{4}{*}{ County } & \multicolumn{3}{|c|}{$\begin{array}{c}\text { Akron winds from the south } \\
(\mathrm{n}=24)\end{array}$} & \multicolumn{3}{c}{ Akron winds not from the south } \\
\cline { 2 - 9 }$(\mathrm{n}=30)$
\end{tabular}


in the area at all times. Highlights of the results by heating season are presented below.

Sulfate Results--

Table 4-8 summarizes the results for $\mathrm{SO}_{4}^{-2}$ deposition rates for the heating seasons. At all stations shown, the average sulfate deposition rate during the nonheating season (summer) is greater than in the winter; the difference ranges from $7.9 \mathrm{mg} / \mathrm{m}^{2} / \mathrm{cm}$ in Noble County to $19.6 \mathrm{mg} / \mathrm{m}^{2} / \mathrm{cm}$ in Huilingdon County. Thesc results are in agreement with those observed by many other experimenters. The higher $\mathrm{so}_{4}^{-2}$ deposition rates during the nonheating period are due to rapid precursor oxidation in the warmer months. Except at the Noble County station, the winter deposition rates differ significantly from the summer deposition rates, reflected by the large difference between the data set means (10.3 at wayne County, 14.5 at Elk County, and 19.6 at Huntingdon County).

One explanation concerning the the seasonal differences between the deposition rates at each station is that the magnitude of the seasonal differences at each station is greater at those stations that are impacted most by nedrby precursor emissions. This could be due to the rapid oxidation of materials in the summer, which would allow for deposition after only a short residence time in the reactive atmosphere. The longer residence time in the winter months due to slower oxidation rates causes pollutant deposition farther away from the emission point. Thus, deposition at a station where the seasonal difference is small must result from farther-removed sources of precursor emissions 
TABLE 4-8. SUMMARY OF OHIO/PENNSYLVANIA RESULTS

A. Average Deposition Rates and standard Deviations, $\mathrm{mg} / \mathrm{m}^{2} / \mathrm{cm}$ of $\mathrm{ppt}$

\begin{tabular}{|c|c|c|c|c|c|c|c|c|c|c|c|c|}
\hline \multirow[b]{3}{*}{ Station } & \multicolumn{4}{|c|}{ Ali concurrent observations ${ }^{a}$} & \multicolumn{4}{|c|}{ Heating season ${ }^{b}$} & \multicolumn{4}{|c|}{ Nonheating season ${ }^{C}$} \\
\hline & \multicolumn{2}{|c|}{$\mathrm{SO}_{4}^{-2}$} & \multicolumn{2}{|c|}{$\mathrm{NO}_{3}^{-}$} & \multicolumn{2}{|c|}{$\mathrm{SO}_{4}^{-2}$} & \multicolumn{2}{|c|}{$\mathrm{NO}_{3}^{-}$} & \multicolumn{2}{|c|}{$\mathrm{SO}_{4}^{-2}$} & \multicolumn{2}{|c|}{$\mathrm{NO}_{3}$} \\
\hline & $\bar{x}$ & $\mathbf{s}$ & $\overline{\bar{x}}$ & 5 & $\bar{x}$ & 5 & $\bar{x}$ & s & $\overline{\bar{x}}$ & 5 & $\bar{x}$ & s \\
\hline $\begin{array}{l}\text { Noble } \\
\text { Mayne } \\
\text { Elk } \\
\text { Huntlagdon }\end{array}$ & $\begin{array}{l}43.8 \\
44.8 \\
39.6 \\
43.2\end{array}$ & $\begin{array}{l}20.8 \\
20.6 \\
20.2 \\
26.9\end{array}$ & $\begin{array}{l}24.3 \\
25.5 \\
25.5 \\
29.2\end{array}$ & $\begin{array}{l}13.8 \\
12.8 \\
15.2 \\
1 B .3\end{array}$ & $\begin{array}{l}38.6 \\
37.9 \\
30.0 \\
30.2\end{array}$ & $\begin{array}{l}22.0 \\
19.8 \\
19.8 \\
18.8\end{array}$ & $\begin{array}{l}29.0 \\
28.4 \\
27.8 \\
33.0\end{array}$ & $\begin{array}{l}17.4 \\
17.3 \\
17.6 \\
19.3\end{array}$ & $\begin{array}{l}46.5 \\
48.2 \\
44.5 \\
49.8\end{array}$ & $\begin{array}{l}19.9 \\
20.4 \\
18.9 \\
28.1\end{array}$ & $\begin{array}{l}21.9 \\
24.1 \\
24.3 \\
27.3\end{array}$ & $\begin{array}{r}11.1 \\
9.9 \\
13.9 \\
17.7\end{array}$ \\
\hline
\end{tabular}

$a_{n=54}$

$b=18$

c $n=36$

B. Intersite Correlation Coefficients

\begin{tabular}{|c|c|c|c|}
\hline & \multicolumn{3}{|c|}{ Sulfate } \\
\hline & Hayne & Elk & Hunt ingdon \\
\hline \multirow[t]{2}{*}{$\begin{array}{l}\text { Noble } \\
\text { Mayne } \\
\text { Elk }\end{array}$} & 0.40 & $\begin{array}{l}0.64 \\
0.40\end{array}$ & $\begin{array}{l}0.51 \\
0.30 \\
0.65\end{array}$ \\
\hline & Wayne & Elk & Kuntingdon \\
\hline \multirow[t]{2}{*}{$\begin{array}{l}\text { Noble. } \\
\text { Nayne } \\
\text { Elk }\end{array}$} & 0.65 & $\begin{array}{l}0.51 \\
0.46\end{array}$ & $\begin{array}{l}0.56 \\
0.37 \\
0.64\end{array}$ \\
\hline & Hayne & Elk & Hunt ingdon \\
\hline $\begin{array}{l}\text { Noble } \\
\text { Nayne } \\
\text { Elk }\end{array}$ & 0.22 & $\begin{array}{l}0.69 \\
0.29\end{array}$ & $\begin{array}{c}0.47 \\
0.21 \text { (NS) } \\
0.61\end{array}$ \\
\hline
\end{tabular}

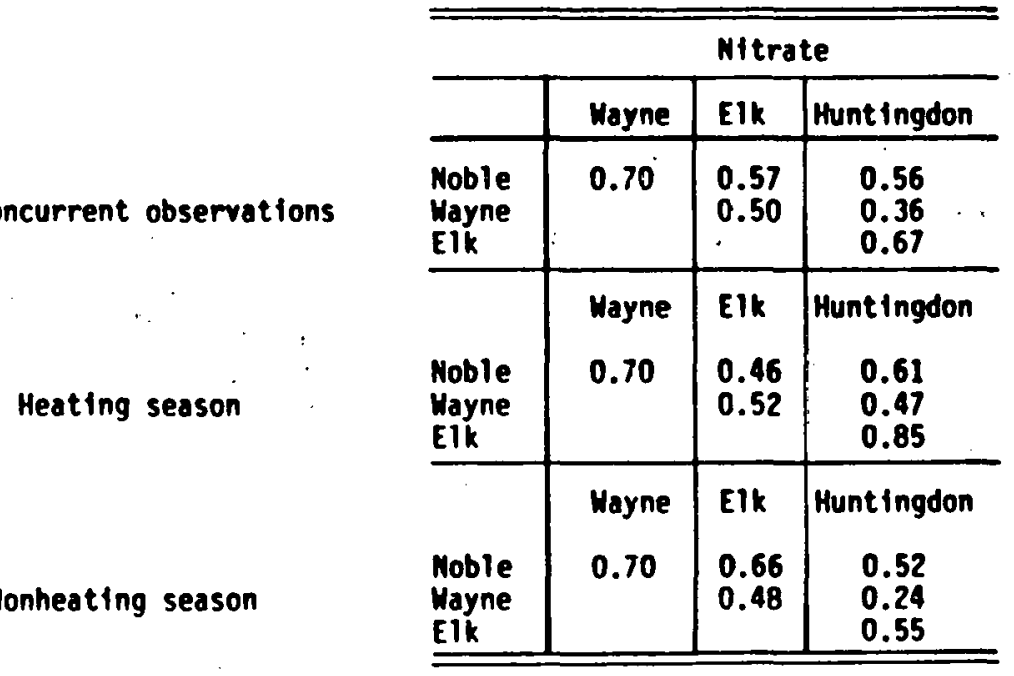

a $=$ Not significant ot the 90 percent level. 
or from sources emitting primary sulfates. Stations where seasonal differences are large are receiving less deposition in the winter because the precursors have not oxidized at a rate commensurate with summer oxidation, and the closeness of the emission source to the monitoring station does not allow for significant winter month oxidation/deposition. As previously shown in Figure 3-10 (reproduced herein as Figure 4-7), the Huntingdon station is immodiately downwind of the high emission density areas surrounding Pittsburgh, whereas no noticeable hotspots occur immediately upwind of the Elk and Wayne stations. Elk, which is the closer to a hotspot emission area than wayne, shows the higher seasonal difference of the two. (Note: this explanation could also apply to New York, where the largest seasonal $\mathrm{so}_{4}^{-2}$ deposition rate difference is observed at the station closest to New York City, and the smallest seasonal difference occurs at the station farthesl away.)

The intersite correlations in Table 4-8 substantiate this theory somewhat. With the exception of the Wayne/Huntingdon comparison, the significant correlation between the sulfate deposition rates at the six pairs of stations in both winter and summer (in conjuction with the lack of a significant difference between the means) indicates that the ctatione are impacted by the same polluted air mass in each season. The correlations between five of the six station pairs are lower in the summer. (nonheating season), however, than in the winter, and all standard deviations are greater. This indicates a greater tendency 


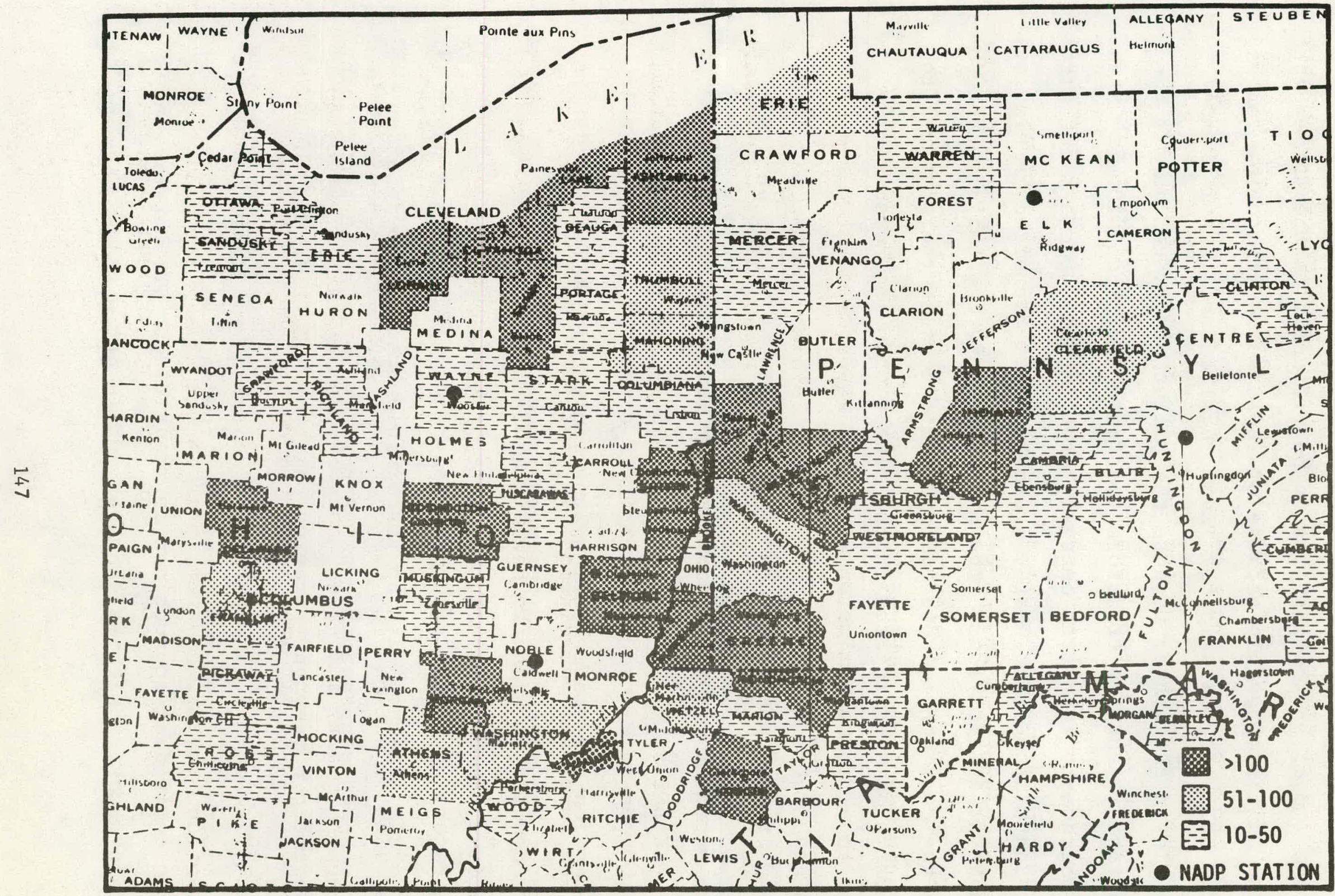

Figure 4-7. Emission density ranges of $\mathrm{SO}_{\mathrm{x}}$ (tons/yr/mi${ }^{2}$ ) by county for a11 sectors combined in the Ohio/Pennsylvania study area. 
for the impact on the stations to be different in the summer than in the winter, possibly because of rapid summertime oxidation of nearby precursor emissions. These local effects are less noticeable in the winter because the pollutants travel across the area faster, and the transformation rates are much slower. Thus, the pollutants leave the emission area faster, become mixed with pollutants from other nearby areas, and are deposited in similar amounts at all stations. 'I'he mixing heights and emission rates have the most control over deposition and cause the stations to be more highly correlated in the winter than in the summer.

\section{Nitrate Results--}

Nitrate deposition rates at all stations, shown in Table 4-8, are observed to be greater during the heating season than in the nonheating season, due to widespread area source emissions (reproduced in Figure 4-8). This is caused by increased fuel consumption for space heating and reduced mixing heights in the winter. The seasonal differences range from 3.5 at Elk County to 7.1 at Noble County. All intersite correlation coefficients are significant at the 90 percent level between all station pairs during all seasons, with no discernible trend in correlation strength between seasons. ANOVA results revealed no significant differences between any station pair for all three data sets analyzed. Thus, there is no reason to believe that the stations are impacted by anything other than the same well-mixed air mass and no individual sources can be identified. The higher winter nitrate deposition rates, however, while not a surprise based on 


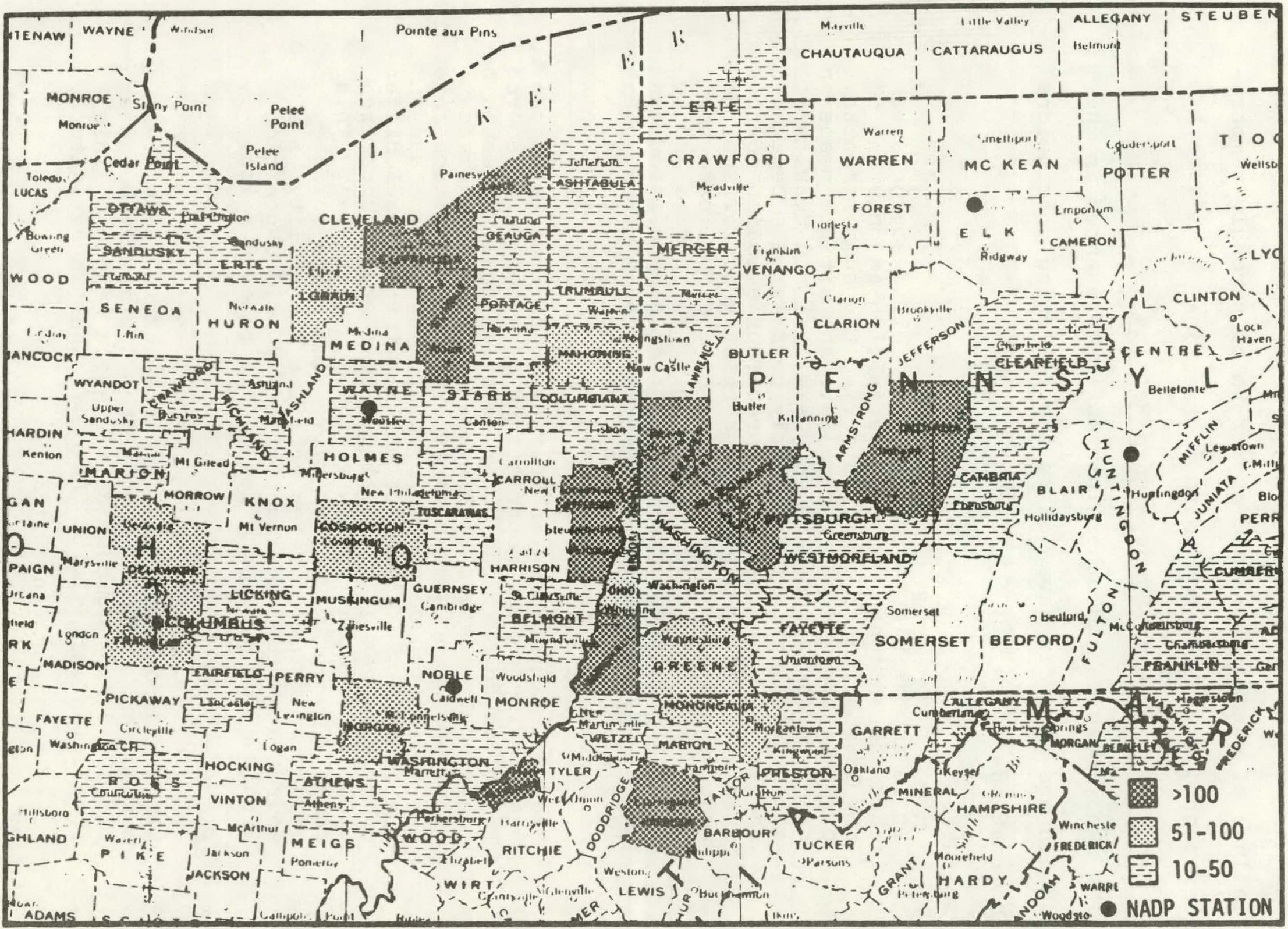

Figure 4-8. Emission density ranges of $\mathrm{NO}_{\mathrm{x}}$ (tons/yr/mi2) by county for all sectors combined in the Ohio/Pennsylvania study area. 
the findings of others, does not appear to be strongly temperature-dependent, as in the $\mathrm{SO}_{2}$ to $\mathrm{So}_{4}^{-2}$ reaction.

\subsubsection{Discussion of Ohio/Pennsylvania Results}

The study results and other information presented in the text and in the appendix have led to the following conclusions and observations:

1. Sulfates

- It is impossible to identify a specific source area that has an impact on acid deposition at only one of the four slaliuns andyzed during the summer months. During these months, the sulfate and nitrate means and standard deviations are very similar, and results at all stations are significantly correlated. Because of the large concentration of precursor emission sources within the study area and the relatively few sources west of the area, the results seem to implicate the study area itself as the source of pollutants and to demonstrate that a great deal of acid deposition can occur under stagnated atmospheric conditions within the localized impact range of approximately 80 to 240 kilometers (b0 to 150 miles).

- Seasonal differences in sulfate deposition rates can be used to locate the contribution of a suspected sourcc to acidic deposition, but a detailed analysis would be required to confirm such suspicions. The observed relationship between seasonal sulfate deposition rates and the distance between a monitoring station and an upwind source area indicates that the seasnnal difference is larger at the stations nearcst a source area than at those farther away from a source area. This result, due primarily to rapid summertime sulfate oxidation rates, further verifies the ability of a source area to contribute to heavy acid deposition within a few hundred miles of its relcasc point.

2. Nitrates

- Nitrate deposition rates are greater in the winter months than in the summer months, primarily because of increased fuel combustion for space heating. This conclusion agrees with those of other investigators. 


\subsection{TENNESSEE/SOUTH CAROLINA/NORTH CAROLINA AREA}

\subsubsection{Station Locations}

Five NADP stations are located within this study area. Figure 4-9 shows the general study area, the location of the deposition stations, and other relevant information. Table 4-9 presents other pertinent information regarding the stations. The Sevier County station began operations on August 12, 1980, and available data at this station are sparse; therefore, it is not included in this analysis. When additional data become available, it will represent a valuable additional point for analysis. 4.4.2 Physical Features of the Study Area

The NADP stations in this study area are located within three distinctly different physical areas. The Anderson County station is situated within a valley and ridge area consisting predominantly of valley belts. Immediately west of the Anderson station [elevation $300 \mathrm{~m}(984 \mathrm{ft})$ ], ridge elevations increase to approximately $1070 \mathrm{~m}(3500 \mathrm{ft})$. The valley area is relatively narrow from Chattanooga northwest into Virginia. Its eastern side is defined by the southern section of the Blue Ridge formation, which includes the Great Smoky Mountain National Park and Nantahala National Forest. The Macon County station is located within the Nantahala National Forest. Its elevation is high, but not as high as those of the surrounding areas, which are the highest points in each of the four states shown in this figure. The Pickens, South Carolina, and Rowan, North Carolina, stations are located in the Piedmont Upland formation, which lies to the 


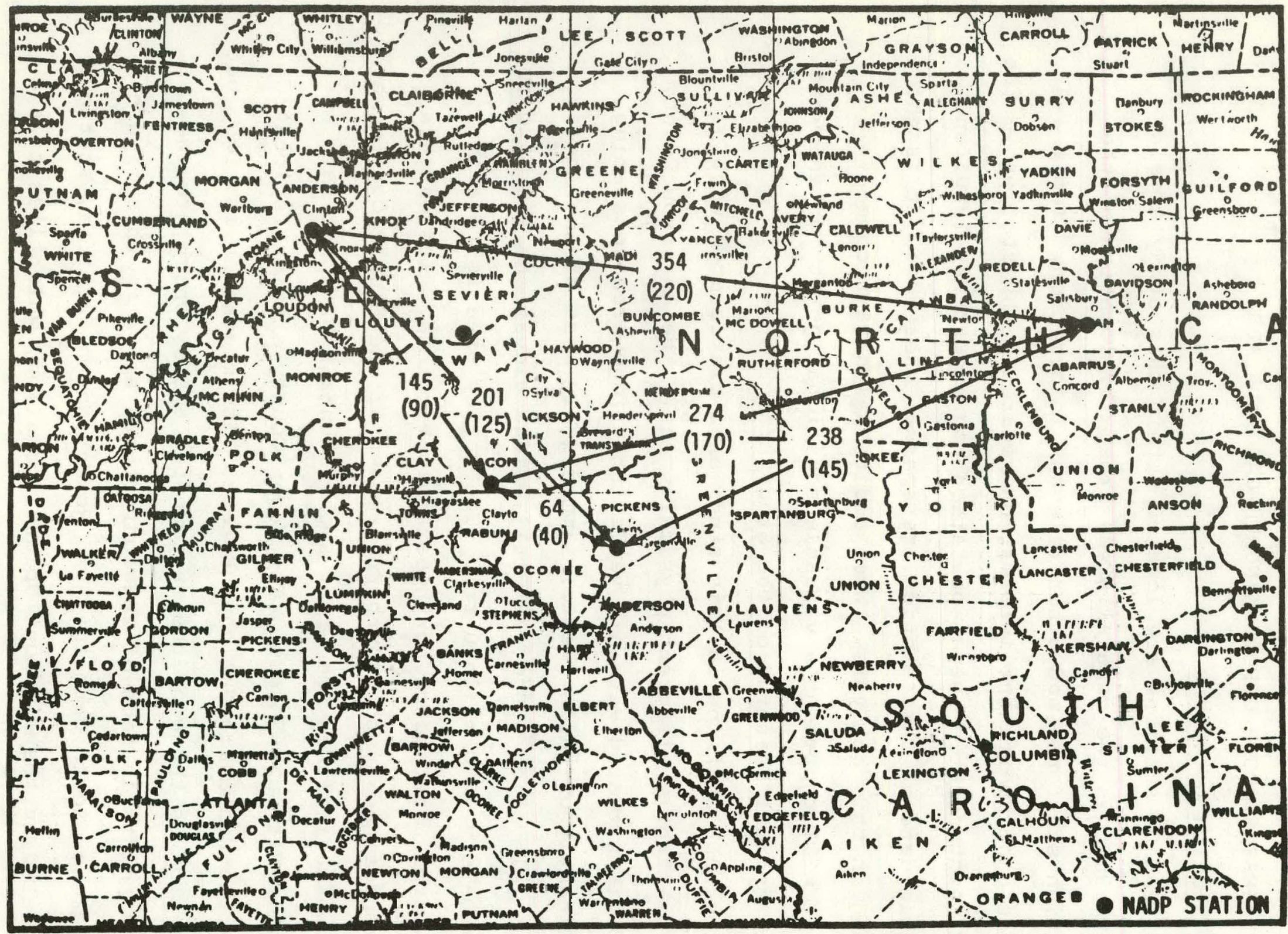

Figure 4-9. Tennessee/South Carolina/North Carolina study area, station locations, and separation distances in kilometers (miles). 
TABLE 4-9. ACID DEPOSITION STATIONS IN THE TENNESSEE/SOUTH CAROLINA/NORTH CAROLINA AREA

\begin{tabular}{|c|c|c|c|c|}
\hline County & Station number & Latitude & Longitude & $\begin{array}{c}\text { Elevation, } \\
m(f t) \text { above } \\
\text { mean sea level }\end{array}$ \\
\hline Pickens, SC & 421880 & $34^{\circ} 40^{\prime}$ & $82^{\circ} 50^{\prime}$ & $231(758)$ \\
\hline Anderson, TN & 440040 & $35^{\circ} 58^{\prime}$ & $84^{\circ} 17^{\prime}$ & $300(984)$ \\
\hline Sevier, TN & 441190 & $35^{\circ} 40^{\prime}$ & $83^{\circ} 20^{\prime}$ & 655 (2149) \\
\hline Macon, NC & 342500 & $35^{\circ} 03^{\prime}$ & $83^{\circ} 27^{\prime}$ & $722(2369)$ \\
\hline Rowan, NC & 343460 & $35^{\circ} 40^{\prime}$ & $80^{\circ} 34^{\prime}$ & $110\left(360^{a}\right)$ \\
\hline
\end{tabular}

a Approximate elevation. 
east of Nantahala. This area is characterized by moderate relief (approaching $300 \mathrm{~m}(1000 \mathrm{ft}$ ) and lower elevations than the other two areas.

\subsubsection{Meteorological Factors}

Local and mesoscale winds generally affect the transport and dispersion of emissions from source areas to nearby and distant receptor locations. A predominant factor in determining emission transport across the southern Appalachian Mountains is the mountains themselves. In the study area, the mountain ridges lhat run northeast to southwest have the folluwing key effects:

- They act as a barrier to general synoptic-scale, lowpressure systems moving in from the west and northwest, with the effect that winters are not as cold at the sites south and east of the ridges as they usually are in their Midwestern counterparts. Also, the west and northwest winds that prevail in the plains do not prevail in the study area.

- Wind bchavior is terrain-indured, and surface winds are channeled along well-defined corridors.

- The incidence of convective-type thundersturms is higher, especially in spring and summer.

- The sites along the mountain-Piedmont transitional zone are isolated from severe winter weather.

Site-to-site variations in climate are due to location, altitude, proximity to mountain influences, and proximity to Gulf of Mexico-related low-pressure systems. Sites in the southeastern portion of the study area tend to be influenced primarily by storm systems moving up the Atlantic Coast, whereas sites farther into the mountains are influenced by both cold northwestern outbreaks and warm, moist Gulf air. 
Precipitation is generally well distributed throughout the year over the study area, with somewhat greater amounts in the winter when moist Gulf air comes in contact with cold northern air over the mountains and piedmont. The high convective activity in the summertime results in frequent thunderstorms of short duration. On a spatial scale, the patterns of precipitation vary greatly with surface elevation; precipitation ranges from 100 to $255+\mathrm{cm}$ (40 to $100+$ inches) at the highest elevations.

Figure 4-10 shows the monthly prevailing wind directions at several locations for January, April, July, and October. These wind directions point up the disorganized nature of winds over the whole area in January. Winds in April and July are more characteristic of the southwesterly flow associated with synoptic scale activity in the atmosphere. They are modified or enhanced by the effects of the local terrain (e.g., the large, abrupt rise in elevation to the west of Chattanooga), however, which tend to channel the winds more from the south. The october wind flow tends to be from the northeast at all sites.

As in the other study areas, the transport taking place within the mixing layer also must be considered. Mixing heights and wind speeds are greater during precipitation events. They are also somewhat greater in the afternoon hours.

\subsection{Results}

The measurements of acid deposition collected at the Anderson station are of greatest interest because this station is closest to areas of high emission density. For this reason, two 


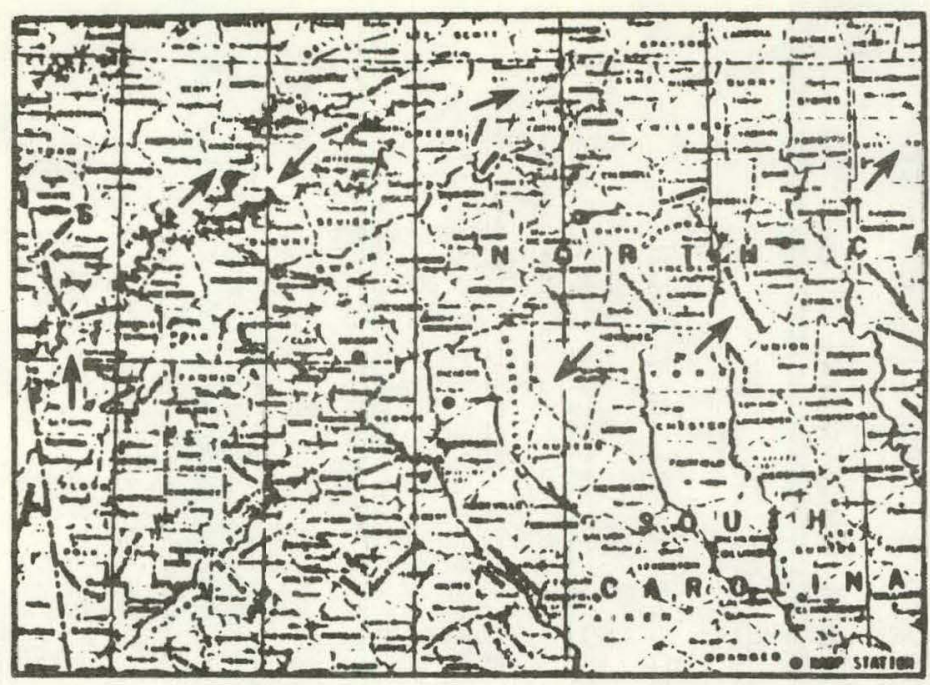

菂
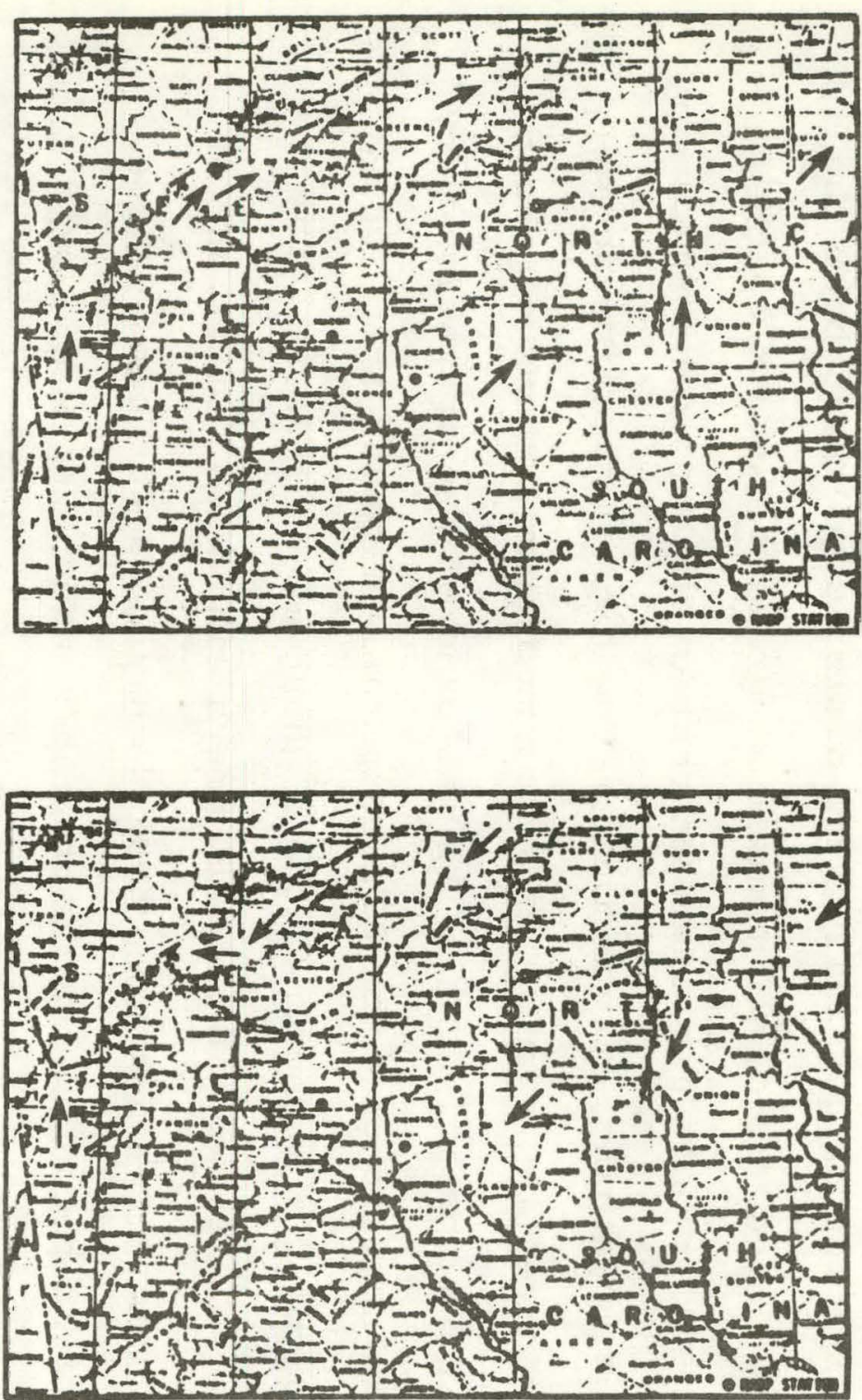

Figure 4-10. Prevailing wind directions in the mountain-Piedmont study area for January, Apri1, July, and October. 
subsets of data were selected for analysis: 1) those values obtained during months when the prevailing surface wind direction at Oak Ridge was from the southwest, and 2) those values obtained during the months when the prevailing surface wind direction was not from the southwest (this includes winds from the east and winds from the east-northeast). Intersite correlations and ANOVA results are presented for the $\mathrm{SO}_{4}^{-2}$ and $\mathrm{NO}_{3}{ }^{-}$data.

The station in Anderson County, Tennessee, did not begin collecting data until March 11, 1980, and represents the limiting factor in data availability. The Pickens County, South Carolina, station began operating on March 27, 1979. The two stations in North Carolina have been collecting data consistently since early in the NADP program (October 17, 1978). Based on the limitations posed by the Anderson County start date, a maximum of 43 weeks of data could be available when all four stations were generating data. As shown in Table 4-10, however, a total of only 21 weekly data points are available between March 11, and December 30, 1980, when all stations were concurrently collecting data.

Sulfate Results--

Table 4-11 presents a summary of the average sulfate deposition rates. The Anderson station has the highest average (37.2) for all data, followed by the Rowan station (35.2). The other two stations have much lower average values $(20.7$ at Macon and 24.5 at Pickens). The most pronounced difference in these results is that between the means measured at Anderson County for the two wind direction data sets and measured means at the other 
TABLE 4-10. NUMBER OF CONCURRENT WEEKLY DATA POINTS AVAILABLE AT FOUR SITES IN TENNESSEE/SOUTH CAROLINA/NORTH CAROLINA

\begin{tabular}{|c|c|c|}
\hline Month & $\begin{array}{c}\text { Data points } \\
\text { available }\end{array}$ & Data group \\
\hline January & 0 & 1 \\
\hline February & 0 & 2 \\
\hline March & 1 & 1 \\
\hline April & 1 & 1 \\
\hline May & 2 & 1 \\
\hline June & 2 & 1 \\
\hline July & 2 & 1 \\
\hline August & 2 & 2 \\
\hline September & 4 & 2 \\
\hline October & 3 & 2 \\
\hline November & 3 & 2 \\
\hline December & 1 & 1 \\
\hline Total & 21 & \\
\hline
\end{tabular}

${ }^{\text {a }}$ Group 1 - Wind from southwest at Oak Ridge; Total $=9$. Group 2 = Wind not from southwest at 0ak Ridge; Total $=12$. 
TABLE 4-11. SUMMARY OF TENNESSEE/SOUTH CAROLINA/NORTH CAROLINA RESULTS

A. Average Deposition Rates and Standard Deviations, $\mathrm{ma} / \mathrm{m}^{2} / \mathrm{cm}$ of ppt

\begin{tabular}{|c|c|c|c|c|c|c|c|c|c|c|c|c|}
\hline \multirow[b]{3}{*}{ Station } & \multicolumn{4}{|c|}{ A11 concurrent observations ${ }^{a}$} & \multicolumn{4}{|c|}{$\begin{array}{l}\text { Surface winds from } \\
\text { southwest at Oak Ridge }\end{array}$} & \multicolumn{4}{|c|}{$\begin{array}{l}\text { Surface winds not from } \\
\text { southwest at } 0 \text { ak } R+d g{ }^{c}\end{array}$} \\
\hline & \multicolumn{2}{|c|}{$\mathrm{SO}_{4}^{-2}$} & \multicolumn{2}{|c|}{$\mathrm{NO}_{3}^{-}$} & \multicolumn{2}{|c|}{$\mathrm{SO}_{4}^{-2}$} & \multicolumn{2}{|c|}{$\mathrm{NO}_{3}^{-}$} & \multicolumn{2}{|c|}{$\mathrm{SO}_{4}^{-2}$} & \multicolumn{2}{|c|}{$\mathrm{NO}_{3}$} \\
\hline & $\bar{x}$ & s & $\bar{x}$ & s & $\bar{x}$ & s & $\bar{x}$ & s & $\bar{x}$ & s & $\bar{x}$ & s \\
\hline $\begin{array}{l}\text { Anderson } \\
\text { Rowan } \\
\text { Pickens } \\
\text { Macon }\end{array}$ & $\begin{array}{l}37.2 \\
35.2 \\
24.5 \\
20.7\end{array}$ & $\begin{array}{l}18.3 \\
22.8 \\
12.5 \\
11.4\end{array}$ & $\begin{array}{l}15.9 \\
17.8 \\
13.9 \\
11.4\end{array}$ & $\begin{array}{r}7.7 \\
12.6 \\
10.0 \\
7.0\end{array}$ & $\begin{array}{l}33.3 \\
35.4 \\
24.1 \\
21.2\end{array}$ & $\begin{array}{r}14.4 \\
12.5 \\
11.6 \\
8.0\end{array}$ & $\begin{array}{l}15.8 \\
16.6 \\
13.9 \\
10.8\end{array}$ & $\begin{array}{l}8.8 \\
8.9 \\
8.4 \\
5.3\end{array}$ & $\begin{array}{l}40.2 \\
35.0 \\
24.7 \\
20.4\end{array}$ & $\begin{array}{l}20.8 \\
28.9 \\
13.6 \\
13.7\end{array}$ & $\begin{array}{l}16.0 \\
18.7 \\
13.9 \\
11.8\end{array}$ & $\begin{array}{r}7.2 \\
15.1 \\
11.5 \\
8.3\end{array}$ \\
\hline
\end{tabular}

$n=21$

$b_{n}=9$

$c_{n}=12$

B. Intersite Correlation Coefficients

\begin{tabular}{|c|c|c|c|c|c|c|c|c|}
\hline \multicolumn{4}{|c|}{ Sulfate } & & & \multicolumn{3}{|c|}{ Nitrate } \\
\hline & Rowan & Pickens & Macon & & & Rowan & Pickens & Macon \\
\hline $\begin{array}{l}\text { Anderson } \\
\text { Rowan } \\
\text { Pickens }\end{array}$ & 0.03 & $\begin{array}{c}-0.09^{b} \\
0.52^{a, b}\end{array}$ & $\begin{array}{l}0.52^{\mathrm{a}, b} \\
0.16^{\mathrm{b}} \\
0.33^{\mathrm{a}}\end{array}$ & Al1 concurrent observations & $\begin{array}{l}\text { Anderson } \\
\text { Rowan } \\
\text { Pickens }\end{array}$ & $0.54^{a}$ & $\begin{array}{l}0.47^{\mathrm{a}} \\
0.52^{\mathrm{a}}\end{array}$ & $\begin{array}{l}0.19^{b} \\
0.10^{b} \\
0.19\end{array}$ \\
\hline $\begin{array}{l}\text { Anderson } \\
\text { Rowan } \\
\text { Pickens }\end{array}$ & $\begin{array}{l}\text { Rowan } \\
0.65^{\mathrm{a}}\end{array}$ & $\begin{array}{l}\text { Pickens } \\
0.28 \\
0.58^{\mathrm{a}, \mathrm{b}}\end{array}$ & $\begin{array}{l}\text { Macon } \\
0.15^{b} \\
0.38^{b} \\
0.80^{a}\end{array}$ & $\begin{array}{l}\text { Surface winds from southwest at } \\
\text { Oak Ridge }\end{array}$ & $\begin{array}{l}\text { Anderson } \\
\text { Rowan } \\
\text { Pickens }\end{array}$ & $\begin{array}{l}\text { Rowan } \\
0.69^{\mathrm{a}}\end{array}$ & $\begin{array}{l}\text { Pickens } \\
0.48^{\mathrm{a}} \\
0.26\end{array}$ & $\begin{array}{l}\text { Macon } \\
0.31 \\
0.22 \\
0.64^{8}\end{array}$ \\
\hline $\begin{array}{l}\text { Anderson } \\
\text { Rowan } \\
\text { Pickens }\end{array}$ & $\begin{array}{l}\text { Rowan } \\
-0.10\end{array}$ & $\begin{array}{l}\text { Pickens } \\
-0.26^{b} \\
0.53^{\mathrm{a}}\end{array}$ & $\begin{array}{l}\text { Macon } \\
c .66^{a, b} \\
0.12 \\
0.17\end{array}$ & $\begin{array}{l}\text { Surface winds not from southwest } \\
\text { at Oak Ridge }\end{array}$ & $\begin{array}{l}\text { Anderson } \\
\text { Rowan } \\
\text { Pickens }\end{array}$ & $\begin{array}{l}\text { Rowan } \\
0.51^{a}\end{array}$ & $\begin{array}{c}\text { Pickens } \\
0.49^{\mathrm{a}} \\
0.60^{\mathrm{a}}\end{array}$ & $\begin{array}{l}\text { Macon } \\
0.65^{a} \\
0.06 \\
0.04\end{array}$ \\
\hline
\end{tabular}

a Significant at 90 percent level.

b ANOVA results are significant for this pair of stations. 
three stations for the same data set. These differences (absolute) between deposition rates as a function of wind direction are $6.9(40.2$ vs. 33.3) at Anderson, $0.4(35.0$ vs. 35.4) at Rowan, 0.8 (24.7 vs. 24.1) at Macon, and 0.6 (20.4 vs. 21.2) at Pickens. These results indicate that contributing sources, transformation rates, and transport at three of the stations do not differ greatly between the two time periods. Conversely, the large difference between the data set averages at Anderson indicate that this station is influenced differently, depending on the air mass that impacts the area.

Analyses of results sorted by wind-direction show that there is no significant correlation between the Anderson station and the Pickens or Rowan stations; this indicates that Anderson is impacted by different sources than the other two stations. The fact that the Anderson and Rowan deposition rates are never significantly different implies that although the same source does not impact both stations, the sources impacting the two stations are similar in nature. This was indicated in Section 3, (reproduced here in Figure 4-11), which shows a similar distribution of $\mathrm{SO}_{\mathrm{x}}$-emission-density counties around both of these stations.

A comparison of Rowan results with those of Pickens and Macon also illustrates the localized-impact effect. No significant correlation is ever apparent between Rowan and Macon, which indicates they are being impacted by different sources. This is not surprising because the physical areas in which these stations are located are different. Rowan and Pickens, on the 


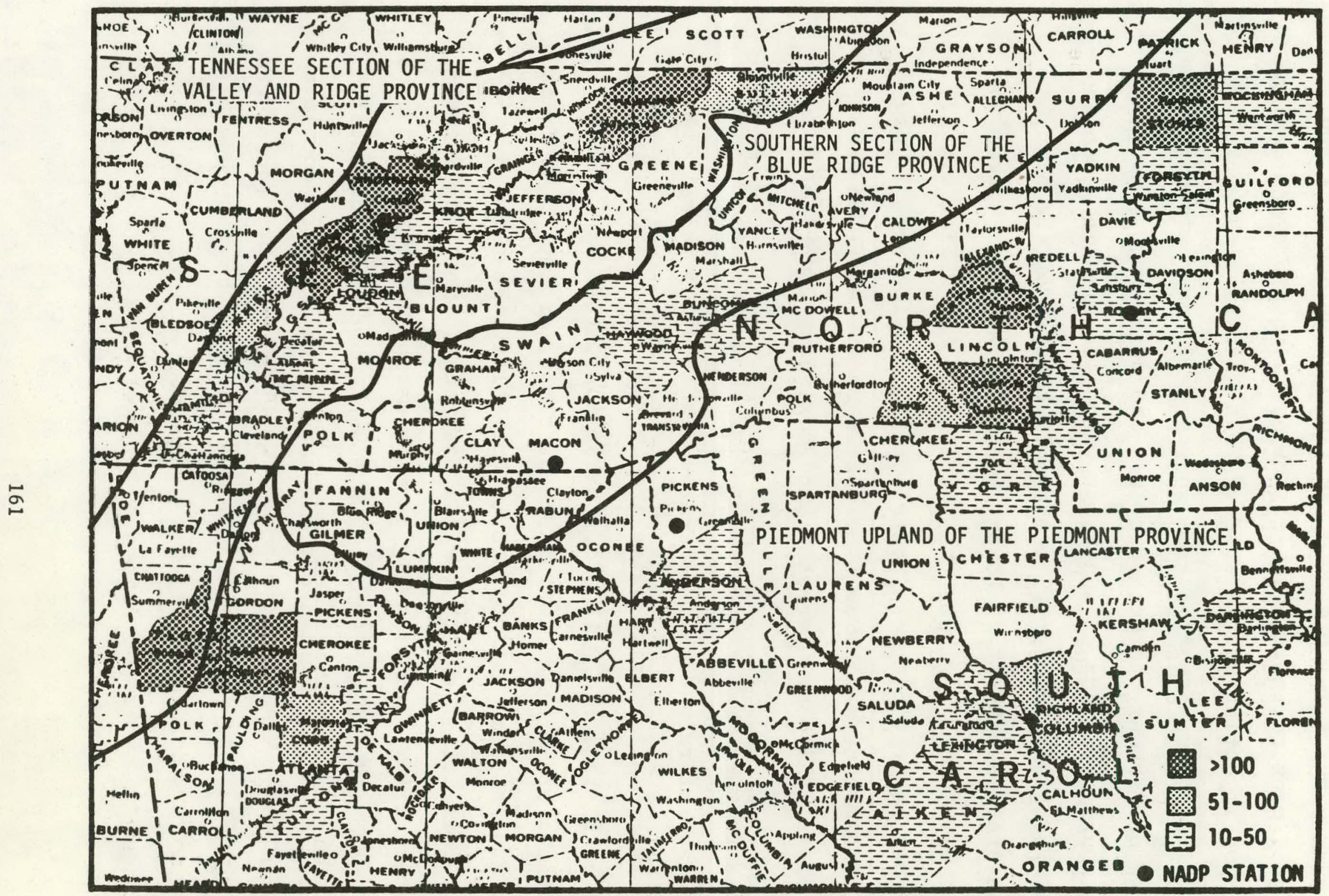

Figure 4-11. Emission density ranges of $\mathrm{SO}_{\mathrm{x}}$ (tons $/ \mathrm{mi}^{2}$ per $\mathrm{yr}$ ) for all sectors combined in the Tennessee/South Carolina/North Carolina study area. 
other hand, both of which are in the Piedmont Upland Division, show significant correlation at all times, a possible indication of the same impacting source areas. This Division (shown in Figure 4-11) encompasses the area in Bartow County extending from southwest of Pickens, through Pickens, and up through Rowan County. During periods of southwest winds, results in Rowan and Pickens differ significantly, presumably because of the high emission areas southwest of Rowan. When the wind comes from the opposite direction, however, the stations do not differ significantly because the previous contributing emission area is now upwind of Pickens, and Rowan is impacted by the emission area upwind of it in Stoker, Forsyth, and Rockingham Counties.

Nitrate Results--

Average nitrate deposition rates (Table 4-11) reveal similar means between most station pairs and between wind direction data sets at each station. With a few exceptions, the intersite correlations are similar in pattern as those for $\mathrm{so}_{4}^{-2}$. Between Pickens and Anderson (as opposed to the sulfate results), significant correlation exists for all data sets. The mean deposition rates differ significantly between Macon County and Anderson County and between Macon County and Rowan County for the total data set. No other significant differences exist. For completeness, the $\mathrm{NO}_{\mathrm{x}}$ emission densities in the study area are reproduced as Figure 4-12. 


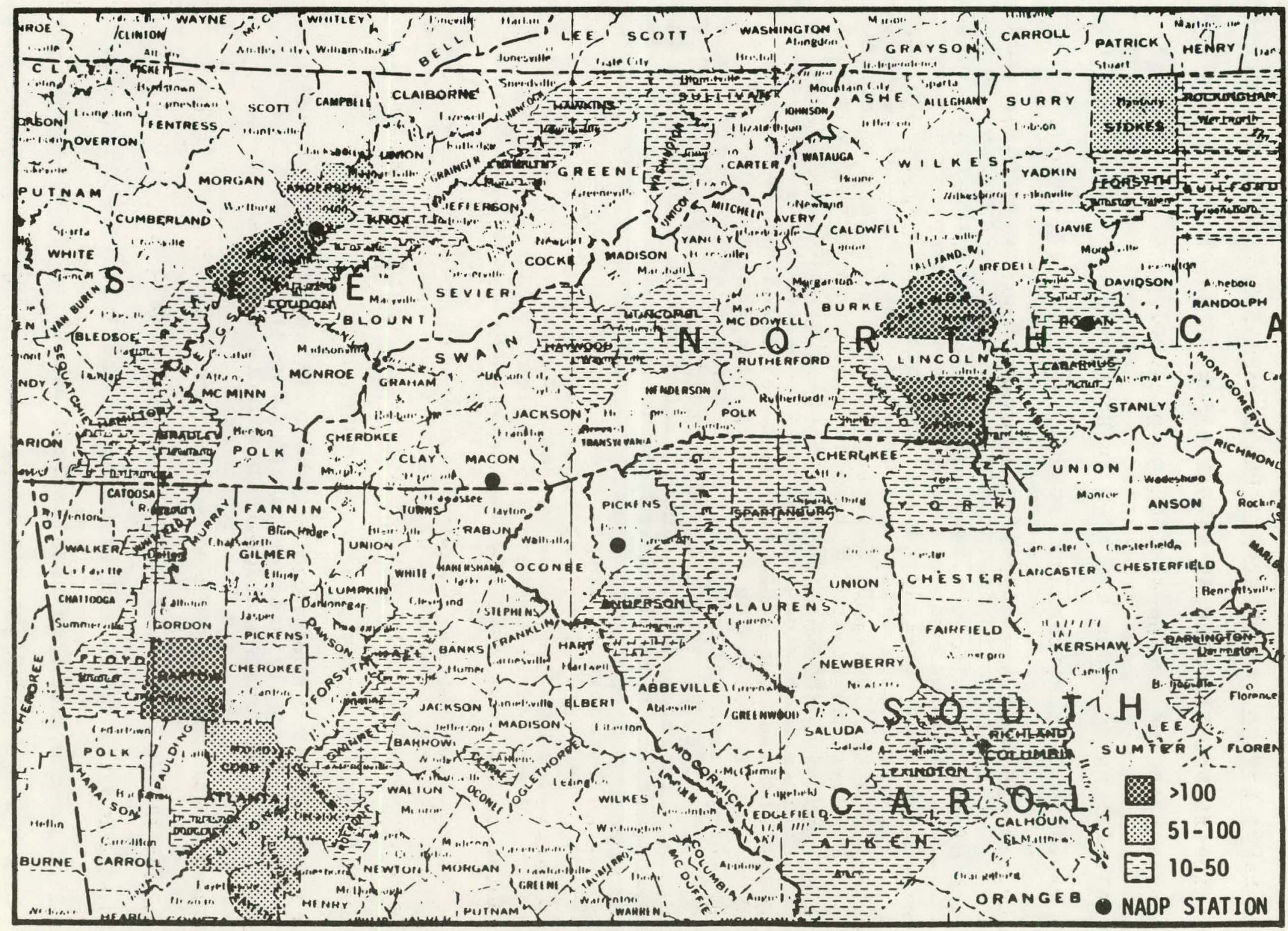

Figure 4-12. Emission density ranges of $\mathrm{NO} \mathrm{N}_{\mathrm{x}}$ (tons/yr/mi2) for all sectors combined in the Tennessee/South Carolina/North Carolina study area. 


\subsubsection{Discussion of Tennessee/South Carolina/North Carolina Results}

The information and results presented in the text and in the appendix have led to the the following conclusions and observations:

1) Sulfates

- The impact of specific sources or source areas at individual monitoring stations are readily apparent in the area. This conclusion is based on the following results: a) the two stations that are most distant from emission sources generally do not correlate with those nearer to a precursur emissijun dred, and most often have significantly lower $\mathrm{SO}_{4}-2$ deposition rates; b) the Anderson station, upwind of two differcnt strong source areas (depending on wind direction), has a higher deposition rate when winds come from the direction of the area having higher $\mathrm{SO}_{2}$ emission densities, whereas other stations in the area remain essentially unchanged; c) significant differences between stations occur when a readily identifiable emission area is near one of the stations-for instance, Gaston and Stokes Counties in relation to the Rowan station.

- The impact of source areas in proximity to a station is apparent. Those station pairs separated by physical divisions, such as mountain ridges or distances greater than 240 kilomelers (150 miles), generally do not correlate with one another; this illustrates the tendency for precursor emissions to be transformed and deposited fairly close to the emission source. The channelling effects of mountains and valleys are also evident.

2) Nitrates

- The two most highly industrialized areas produce significantly greater nitrate deposition rates than the most rural station. This industrial and/or urban activity is a likely contributor.

\subsection{COMPARISON OF STUDY RESULTS AND CONCLUSIONS}

The following is a discussion of the inferences that can be applied to the combined results from all three study areas, based 
on the interpretative guidelines discussed in the introduction to this section and all factors that affect acid deposition.

A total of 11 stations in three study areas were analyzed; this permits comparisons of 15 separate station pairs. Tables 4-12 and 4-13 present an overview comparison of each of the three study areas. Because there is always a chance that an incorrect interpretation can be derived from statistical tests performed with less than 100 percent confidence, some measure of conservativeness is incorporated into the conclusions for each station pair. Therefore, a conclusion regarding the existence of a unique source impact at one of the stations is made only after "false" answers apply to at least two statements relating to the similar means and variation between the station pairs.

These tables present four combinations of true and false statements for the analysis of sulfate and nitrate for each station pair test. These combinations and their inferences are:

Combination

1) Similar variation - $\mathrm{T}$ Similar mean - T

2). Similar variation - F Similar mean

$-F$

3) Similar variation - $\mathrm{T}$ Similar mean $-\mathrm{F}$

4) Similar variation - F Similar mean - $\mathrm{T}$
Inference

The pair receives similar impact from the same source or source area.

The pair receives impact from completely different sources or source areas and at different deposition rates.

The pair receives impact from the same source or source areas, but the impact is not equal because of the physical features or emission characteristics of the area.

The pair receives impact from completely different sources, but the deposition rates are the same. 
TABLE $\varepsilon_{-}$-12. SUMMARY OF SULFATE RESULTS FOR ALL STUDY ARE.AS

\begin{tabular}{|c|c|c|c|c|c|c|c|c|c|c|c|c|c|c|c|}
\hline \multirow{3}{*}{ Test performed" } & \multicolumn{15}{|c|}{ Study orea/station pair (county)/distan=e belmean stat ions(twiles) } \\
\hline & \multicolumn{3}{|c|}{ New Tort-thedson River Yalley } & \multicolumn{6}{|c|}{ Ohlo/Pennsylyanla } & \multicolumn{6}{|c|}{ Tennes see/Morth Carol Ina/South Carol Ine } \\
\hline & $\begin{array}{l}\text { Orange: } \\
\text { Essex: } \\
1190:\end{array}$ & 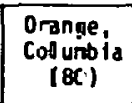 & \begin{tabular}{|c|} 
Col untiofid. \\
Issex, \\
$(120)$
\end{tabular} & \begin{tabular}{|l|} 
Roynne. \\
nobble \\
$170 i$
\end{tabular} & \begin{tabular}{|c|} 
Mayne \\
Eik \\
(175) \\
\end{tabular} & \begin{tabular}{|c|}
$\begin{array}{c}\text { Mayne } \\
\text { Huntingdon } \\
(210)\end{array}$ \\
\end{tabular} & \begin{tabular}{|l|} 
Noble \\
[1k \\
$1190)$
\end{tabular} & \begin{tabular}{|c|} 
Moble \\
Munt ingdon \\
$(200)$
\end{tabular} & \begin{tabular}{|c|} 
Elk. \\
Innetingos \\
(75)
\end{tabular} & $\begin{array}{c}\text { Anderson, } \\
\text { Mocoon } \\
(90)\end{array}$ & \begin{tabular}{|l|} 
Anderson \\
Pickens, \\
(125)
\end{tabular} & \begin{tabular}{|l|} 
Anderson, \\
Roman \\
(220)
\end{tabular} & $\begin{array}{c}\text { Macon } \\
\text { Pickens } \\
(40)\end{array}$ & \begin{tabular}{|c|}
$\begin{array}{c}\text { Macon. } \\
\text { Roman } \\
\text { (170) }\end{array}$ \\
\end{tabular} & \begin{tabular}{|l} 
Pickens, \\
Rowent \\
(1145)
\end{tabular} \\
\hline \multicolumn{16}{|l|}{ All observations display: } \\
\hline 1) siallar week to week variation & $\mathbf{T}$ & $\mathrm{T}$ & $\mathbf{T}$ & 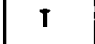 & $\mathbf{T}$ & $\mathbf{I}$ & $\mathbf{T}$ & $\mathbf{T}$ & $\mathbf{T}$ & $\mathbf{T}$ & $\mathbf{F}$ & $\mathbf{F}$ & $\mathbf{T}$ & $\mathbf{F}$ & $\mathbf{T}$ \\
\hline 2) Similar mean deposition rates & $\mathbf{F}$ & $\mathbf{T}$ & $\mathbf{F}$ & 1 & $\mathbf{T}$ & $\mathbf{T}$ & $\mathbf{T}$ & $\mathbf{T}$ & $\mathbf{T}$ & $\mathbf{F}$ & $\mathbf{F}$ & $\mathbf{I}$ & $\mathbf{T}$ & $\mathbf{F}$ & $\mathbf{f}$ \\
\hline \multicolumn{16}{|l|}{ Group 1 observations" display: } \\
\hline ") sindlar week to week variation & $\boldsymbol{\top}$ & 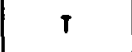 & $\mathbf{T}$ & $\mathbf{F}$ & $\mathbf{T}$ & $\mathbf{T}$ & $\mathbf{T}$ & $\mathbf{T}$ & $\mathbf{T}$ & $\mathbf{F}$ & $\mathbf{F}$ & $\mathbf{T}$ & $\mathbf{T}$ & $\mathbf{F}$ & $\mathbf{T}$ \\
\hline 2) siallar mean defosition rates & $\mathbf{F}$ & $\mathrm{T}$ & $\boldsymbol{f}$ & $T$ & $T$ & $\mathbf{r}$ & $\mathbf{r}$ & $\boldsymbol{T}$ & $\mathbf{T}$ & $\boldsymbol{F}$ & $\mathbf{T}$ & $\boldsymbol{T}$ & $\mathbf{r}$ & $\mathbf{F}$ & $\mathbf{F}$ \\
\hline \multicolumn{16}{|l|}{ Growp 2 observations ${ }^{c}$ Alsplay: } \\
\hline 1) Sinflar week to meek variation & $\mathbf{F}$ & $\pi$ & 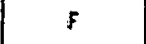 & 1 & $\mathrm{~T}$ & $\mathbf{T}$ & $\mathbf{T}$ & $\mathbf{T}$ & $\mathbf{T}$ & $\mathrm{T}$ & $\mathbf{F}$ & $\mathbf{F}$ & $\mathbf{F}$ & $\mathbf{F}$ & $\mathbf{I}$ \\
\hline 2) Sifflar mean deposition rates & $T$ & $\mathbf{r}$ & 1 & $T$ & $\boldsymbol{T}$ & $\boldsymbol{T}$ & $\top$ & 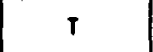 & $\boldsymbol{T}$ & $\mathbf{f}$ & $\mathbf{F}$ & $\mathbf{T}$ & $\mathbf{T}$ & $\mathbf{T}$ & $\boldsymbol{T}$ \\
\hline \multirow{3}{*}{$\begin{array}{l}\text { Crowp } 3 \text { observations }{ }^{d} \text { display: } \\
\text { 1) Stwilior meek to weet vartation } \\
\text { 2) sinflar mean depesition rates }\end{array}$} & uspe & Iisp & MSP & & & & & & & MSP & MSP & MSP & MSP & usp & 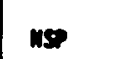 \\
\hline & & & & $\mathbf{I}$ & $\mathbf{T}$ & $\mathbf{T}$ & $T$ & $\mathbf{T}$ & $\mathbf{T}$ & & & & & & \\
\hline & & & & $\mathbf{T}$ & $\top$ & $\mathbf{T}$ & $\mathbf{T}$ & 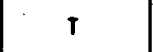 & $\mathbf{r}$ & & & & & & \\
\hline \multirow{3}{*}{ 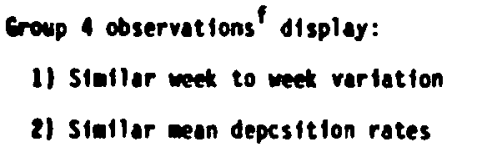 } & MSP & iss & MSP & & & & & & & MSP & MSP & usp & usp & us & $m$ \\
\hline & & & & T & $\mathbf{T}$ & $\mathbf{f}$ & $\mathbf{T}$ & $\mathbf{T}$ & $T$ & & & & & & \\
\hline & & & & $\mathbf{T}$ & $\mathbf{T}$ & $\boldsymbol{T}$ & $\mathrm{T}$ & 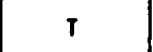 & $\boldsymbol{\top}$ & & & & & & \\
\hline $\begin{array}{l}\text { Conclusion: There is no discernible } \\
\text { effect due to dunlque } \\
\text { source ipoct ot one of } \\
\text { the stat lons in the pair. }\end{array}$ & $\mathbf{F}$ & r & $\mathbf{F}$ & $\mathbf{T}$ & $\boldsymbol{r}$ & 1 & T & $T$ & $T$ & F & $\mathbf{F}$ & 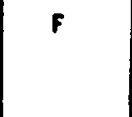 & $\mathbf{T}$ & f & f \\
\hline
\end{tabular}

- $T$ - true, based on the data analyzed and 908 corfidence; $F=$ not true, based on date analyzed and 903 confidence.

- Croup 1 observations: Mew York area - surface minds Fran the south at Albany. OhioiPennsylvanta area - surface winds from the south at Auron. Tennessee/North Caral ina/South Carolina - surface winds from the soctmurst at Cak Ridge.

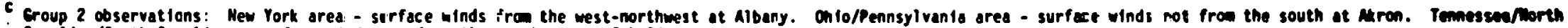
Carol ina/South Carol ina - surface winds not fros the solammest at oud Ridge.

Group 3 observetions: Meating season.

- wse - no sort performed for this group.

Growp observat lons: nonteating sedson. 
TABLE $6=23$. SUMMARY OF NITRATE RESULTS FOR ALL STUDY AREAS

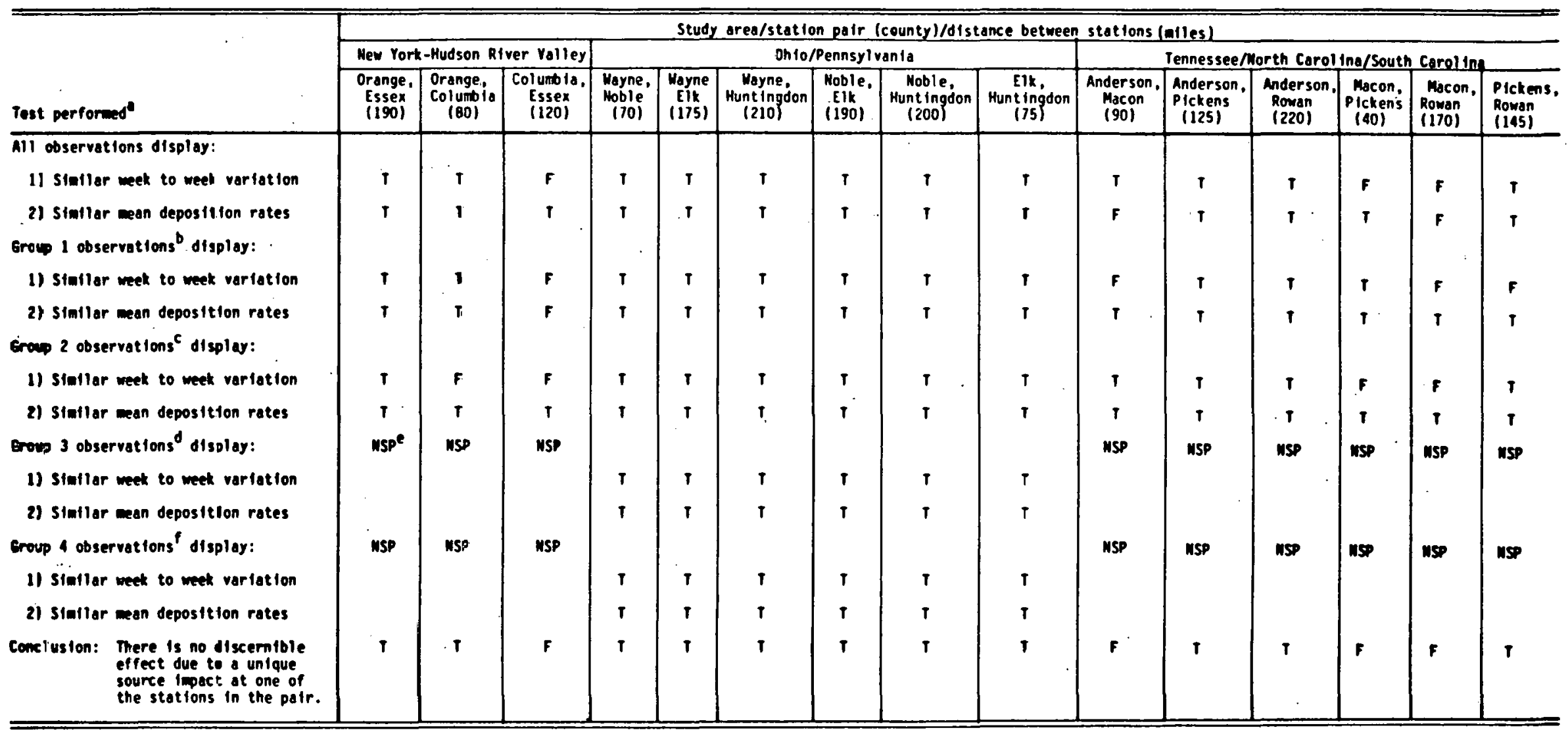

T - true, based on the data analyzed and 908 confidence; $F$ - not true, based on data anslyzed and 908 confidence.

crow 1 observations: New York area - surface winds from the south at Aibany. Ohio/Pennsyluania area - surface winds from the south ot Akron. Tennessee/Morth Carolina/South Carolina - surface winds from the southwest at Oak Ridge.

C Erewp 2 observat lons: Dew York ares - surface winds frow the west-northwest at Albany. Ohlo/Pennsylvania area - surface winds not from the south at Akron. Tennessee/Morth

Carol ina/South Carol ina - surface winds not from the southwest at Oak Ridge.

- Group 3 observations: heating season.

- nst - no sort perforned for thls group.

frewp observat tons: nonheating season. 
A review of the information presented in Tables 4-12 and 4-13, and careful consideration of possible combinations of true/false statements and the inferences listed reveal that the conclusions derived concerning the deposition of acid material are consistent based on what is known about the stations in each area.

For sulfates, the following inferences are made:

- In the ohio/Pennsylvania area, it. is not possible to identify a unique source that impacts one of the statione differently from the other. All pairs rereive similar intudel from lie same or similar sources. This is no surprise and is obvious from the similarities of each station with respect to climatology, emission densities, and terrain. The impacts occur within the 80 to 240 kilometer ( 50 to 150 mile) localized impact area.

- One station pair in each of the New York and Tennessee/ South Carolina/North Carolina areas follows the same pattern as the ohio results. In New York, it is not possible to identify a unique source impacting only one of the two stations in the southern part of the Hudson Valley. This is also true for the pair of stations representing the most rural pair in the Tennessee/South Carolina/North Carolina study area.

- Localized impact is obvious in the Tennessee/South Carolina/North Carolina area when several of station pairs are used as examples.

- The New York area clearly displays localized impact; sulfate deposition at Essex County in the Adirondacks is contributed at least partially by the New York City/New Jersey area. The results follow the pattern of both the Ohio/Pennsylvania area and the Tennessee/ North Carolina/South Carolina area in a way that is completely consistent with conclusions obtained in those two areas.

For nitrates, the inferences are as follows:

- A unique source or source area impact is apparent in the comparison between a station in the southern part of the Hudson Valley and one in the northern part. This source area is most likely the metropolitan areas south of the valley. 
- The most rural station in the Tennessee/North Carolina/ South Carolina area is definitely impacted diffently by nitrate precursor emission sources than the more urban stations.

- The Ohio/Pennsylvania nitrate results lead to identical conclusions as those derived for sulfates. The nitrate results in this area also confirm the greater winter nitrate deposition rates often discussed in literature.

One clear conclusion is verified by the results obtained in each of the three areas (especially for sulfates)--the rate at which acid materlal is deposited at a particular location is greatly influenced by the characteristics of the impacted area [typically within an $80-$ to $240-k i l o m e t e r ~(50$ to 150 mile) radius] of the site in question. 
SECTION 5

CONCLUSIONS AND RECOMMENDATIONS

\subsection{CONCLUSIONS}

An analysis of the results of this study produced the following conclusions.

1. The combustion source emission inventory was successfully developed for the Eastern United States. Nearly all important area and point sources have been characterized on a county-by-county basis and entered into a computerized data base. Its design provides flexibility and simplicity that makes it extremely useful in overall analysis of fuel use and emission patterns in the Eastern United States.

2. An analysis of the emission patterns east of the Mississippi produced the following conclusions:

- The use of emission densities was found to be very helpful in defining source contributions and source strengths in various geographical areas. Although not without their weaknesses, emissions densities were judiged to be much better than using total emissions.

- The importance of considering low- and mediumemission-density counties (10-100 tons/mi2 per $\mathrm{yr})$ in addition to the high-emission-density counties was demonstrated. This is because area sources (residential/commercial and transportation) were shown to be important in the production of acid rain precursors, with a considerable amount of emissions present in the low- and medium-emissiondensity counties. 
3. Three regions with basically different emission patterns have been identified and subjected to analysis of deposition data. The geographical distribution of emissions and source types in these regions revealed the following:

- The pattern in the densely populated northeast shows the tendency for large urban areas to be strong contributors to total NO emissions because of the transportation and industrial sectors, and to HC emissions, mainly because of the transportation sector.

- An estimated 60 percent of all acidic precursor compounds emitted by fuel combustion in the study area is produced in 550 counties that form an industrial band across the Eastern United States, extending from Illinois to the Atlantic Ocean and encompassing all areas between Massachusetts and Maryland. With the exception of selected areas, the area south of the industrial band is generally an area of low emission density, but it has pockets. of high- and medium-emission densities. Areas with high-emission densities are strongly influenced by utility emissions, whereas the counties with low- and medium-emission density are more influenced by industrial and area source components.

4. The results of the statistical analysis of acid deposition data were consistent from one study area to the next, and illustrate that sulfate and nitrate deposition rates in each of these areas are, at least partially, a function of the emissions of precursor compounds as near as 50 to 150 miles from the impact areas. Preliminary analysis of the results in each area leads to the following specific conclusions:

- The emission sources in the New York/New Jersey area have varying levels of impact on all the stations evaluated in the Hudson River Valley, with the greatest. impact occurring at stations nearest the suspected sources. In support of this statement is the fact that greater deposition rates are measured when the surface winds originate in the south. When the surface wind is from the west and more parallel with the upper air wind directions, not only are the deposition rates at 
all stations lower than when south winds prevail, but no correlation exists among the stations themselves, except those that are in proximity to one another. During periods of south winds, the contribution of long-range transport in the area cannot be identified.

The stations in the Ohio/Pennsylvania area are located in the industrial band and are impacted by the precursor emissions produced_within the band. The rapid oxidation of $\mathrm{SO}_{2}$ to $\mathrm{SO}^{-2}$ under summertime conditions is evidenced by figher $\mathrm{SO}_{4}^{2}$ deposition rates during the nonheating season. It was not possible to observe any differences between the deposition rates for acidic material at any of the stations in the area. 'lhe relationship between the seasonal differences in deposition rate at each station appears to be a function of the $\mathrm{SO}_{2}$ to $\mathrm{SO}_{4}^{2}$ oxidation rate and the spatial relationship of the monitoring stations and the nearest area of medium to high emission densities.

In the Tennessee/North Carolina/South Carolina area, the effects of nearby emissions on deposition rates were readily apparent. The main station of concern in the area showed a higher average deposition rate when the wind was blowing over high-emission-density areas upwind from the monitor as opposed to when it was blowing from relatively clean areas. During the same period, the average rates at the other stations in the area showed no change. Furthermore, the stations near urbanized areas produced higher average rates than those in more rural areas, which indicates the effect of transportation-related and other source emissions in the surrounding areas.

\subsection{RECOMMENDATIONS}

Based on this study effort and the conclusions presented, the following recommendations are offered:

1. The combustion inventory should be maintained, refined, and expanded to include the remainder of the United States. This includes computerization of data for the remaining western states, and review and upgrading of assumptions for plant production estimates, unit energy consumption, emission factors, and fuel allocation 
methods. In addition, it is recommended that the existing analysis of emission patterns and their relationship to the wet deposition monitoring analysis be extended and strengthened, and included in a final report covering the entire United States. This would include additional NADP data collected during 1981 and 1982, if available in the near future.' In addition, data from the EPRI and MAP3S, networks could be transformed from a precipitation event basis to weekly average acid deposition rates consistent with the NADP data. A more sophisticated analysis of the expanded data base wculd then be performed to further substantiate the conclusions presented in this report.

2. The national data base should be utilized for other issues beside's acid rain related issues. Additional analysis could consist of a more complete description of fuel use patterns plus assessment of new technology.

3. Additional work should be conducted to better define the industrial area source portion of the data base, which now accounts for approximately 15 percent of the. total fuel use. ". Two areas could be investigated.

- Expand the boiler coverage to include units in the $100-250 \times 10^{6} \mathrm{Btu} / \mathrm{h}$ capacity range. Information on boilers of this size is avallable from NELS and MFBI, and a preliminary analysis indicates that these smaller units may account for as much fuel as those greater than $250 \times 10^{5} \mathrm{Btu} / \mathrm{h}$.

- Analyze reported fuel data for IC engines and turbines to develop factors that could be used to estimate the percentage of total industrial fuel use accounted for by these units. This could be used to further reduce the amount of area source fuel (i.e., unexplained) in the industrial sector. 
4. The computerized data base should be made more flexible to facilitate its expanded usage for analyses other than those related directly to acid rain. This would involve expanding the program on the METC computer to include the parameters that were used to develop the fuel and emission estimates (e.g., plant capacities, production data, etc.), as well as the calculational methodologies. The result would be a master program that would permit easy modification of assumptions to of explore alternate scenarios and conduct sensitivity analyoco. Thio would replace the current oystcm that involves development of the fuel and emission data on microcomputers and subsequent transfer of the results exclusively to the METC computer. 
APPENDIX A

BACKGROUND INFORMATION FOR THE ACID DEPOSITION DATA ANALYSIS AND PRESENTATION OF DETAILED RESULTS FOR EACH STUDY AREA

\section{A. 1 INTRODUCTION}

Within the past decade, considerable technical effort has been directed toward identifying the origin, causes, and effects of acid deposition. Background information required for adequate understanding of the acid deposition issue can be found in many different acid rain literature review reports.

During this same decade a large amount of atmospheric sampling also has been conducted to obtain the necessary data for evaluating causes and effects of acid deposition. The data generated in these sampling programs unequivocally show that both acidic and basic materials are being deposited in many portions of the United States and other countries. To mitigate the continued acidification of surface waters and land areas in the Northeastern United States, many have suggested the use of control programs directed at the large coal-consuming regions of the Midwest. Some investigators have stated that the long-range transport (LRT) of the acid precursor material (i.e., sulfur oxides) emitted during coal combustion in this region is largely responsible for the acid rain that occurs in the Northeast. 
The purpose of this analysis of wet deposition monitoring data is to amplify some aspects of this past research by developing a methodology to examine some of the variations present in existing deposition data and thus form a basis for identifying probable sources contributing to the deposition. As with a majority of past studies, although the results of this analysis are quantitative in nature, the conclusions are qualitative and subject to uncertainties in interpretation.

In general, conclusions regarding sources of acid deposition are necessarily a function of the investigators' basic assumptions and method of data analysis. Different investigators can independently arrive at a variety of conclusions from the same set of data, depending on treatment of the raw data base. Of course, such treatment must be founded on the references obtained from other available information. As stated by the well-known statisticians Snedecor and Cochran when discussing the interpretation of statistical results, "Convincing evidence of an association [such as that between midwestern power plants and northeast acid deposition], even though close, does not prove that $X$ is the cause of the variation in $Y$. Evidence of causality must come from other sources." 1

\section{A.1.1 Long-Range Transport Theory}

The foundation of arguments for the theory of LRT begins with the earliest record of acidic rainfall in the northeast United States (Mt. Washington, New Hampshire) in an area of little industrial activity in the White Mountains. ${ }^{2}$ Because the general pattern of low-pressure precipitation systems is from 
the more industrialized areas in the Midwest to the Northeast, the most straightforward conclusion is to associate the upwind trajectory area with the source of the acidic material. Not until fairly recently, however, have some investigators taken a more sophisticated data analysis approach by explaining the variation of collected data rather than explaining how a suspected source's emissions could be transported to the area being investigated. It is the examination of variations in collected wet deposition data that is emphașized herein.

Another reason for the predominance of conclusions regarding LRT is that acid deposition sampling sites are generally placed in areas of relatively light industrial activity to reduce potential bias from nearby sources. As stated in the National Atmospheric Deposition Program (NADP) Site Selection and Certification Manual, selection of a sampler site should be such that "No continuous sources of pollution shall be within 50 kilometers in the direction of the mean wind direction for the site, and 30 kilometers in all other directions." ${ }^{3}$ In addition, a significant portion of the material deposited as acid is apparently transformed from precursor emissions of $\mathrm{SO}_{2}$ and $\mathrm{NO}_{x}$ (primary sulfate emissions obviously require no transformation). Thus, it becomes a difficult task to quantify, or even observe, the effects of sources, between this 50 - or $30-\mathrm{km}$ radius and $800-$ to $1000-k m$ radii studied in the LRT theory.

\section{A.1.2 Focus of This Study}

In this study, data generated by four acid deposition monitoring networks were evaluated for analysis, The evaluation 
led to the selection of sampling stations within the NADP network for analysis using simple statistical procedures. As specified in the NADP criteria, the locations of sampling stations within this network were established "to give accurate and representative information concerning the temporal and spatial variation of precipitation and dry particulate deposition of important chemical constituents." ${ }^{35}$ only wet deposition data are used. Dry deposition analyses are also available on a bimonthly basis. As discussed later, however, completely different deposition functions exist between wet and dry deposition. In addition, there is considerable uncertainty with regard to the adequacy of present methods of measuring dry deposition. Thus, the decision was made to analyze only wet deposition data.

Analyses of the temporal and spatial variations of observed species of the wet samples and the use of emission patterns and meteorological information near the monitoring stations provide possible explanations of the variations in terms of probable source areas. This method utilizes the entire set of available data currently generated at the sites selected for analysis. Thus, this approach is objective in that no preliminary analysis is conducted for the purpose of choosing a few sample observations at a station with which to prove the point in question. Both upper air and surface meteorological data are used to reduce any inherent data anomalies that would lead one to conclude that acid deposition is caused by sources located under 
cloud formation regions hundreds of kilometers away without looking at potential nearby source areas as well.

A comparison of the methodologies of many past analyses with this analysis reveals one main difference. That is, backup data (emission data, meteorological data, etc.) were analyzed to assist in sorting the deposition data received for analysis. These data are not used specifically in the "mechanical" aspects of analyzing the deposition data; rather, they are used in conjunction with the analysis results to provide insight on possible source/receptor relationships regarding the deposited material.

\section{A. 2 FACTORS INFLUENCING WET DEPOSITION}

Although an in-depth review of the factors influencing acid deposition is not presented here, some pertinent aspects of acid deposition are covered as background for the results presented in section 4, and later in this appendix. This does not mean other equally significant facts pertaining to acid deposition have been overlooked; rather, they are considered unnecessary in this particular discussion.

As mentioned previously, two factors combine to cause a somewhat inconclusive description of the acid deposition phenomenon in the United States: 1) monitoring locations are selected to minimize bias due to the proximity of sources to the monitor, and 2) much of the acid material deposited is not emitted directly by industrial sources but is transformed from $\mathrm{SO}_{2}$ and $\mathrm{NO}_{\mathrm{x}}$ to $\mathrm{SO}_{4}^{-2}$ and $\mathrm{NO}_{3}^{-}$. During and after transformation, 
the acidic material is transported some distance before it is collected in a deposition sampler. The combination of these factors produces a collection of data that are difficult to analyze and interpret. It is apparently intended that the samplers not be impacted by nearby sources, and the transformation of the emitted species to the deposited species precludes the easy application of emission tracking procedures.

\section{A.2.1 Transformation}

The transformation process is not completely understood; however, some of the suspected variables governing $\mathrm{SO}_{2}$ and $\mathrm{NO}_{x}$ (precursor) transformation rates include humidity, temperature, insolation, concentrations of precursors present, concentrations of oxidants present, and the presence of influencing catalysts. More is known about conversion of $\mathrm{SO}_{2}$ to $\mathrm{SO}_{4}^{-2}$ than about the $\mathrm{NO}_{x}$ to $\mathrm{NO}_{3}^{-}$transformation processes. Oxidation of $\mathrm{SO}_{2}$ proceeds most rapidly at high temperatures and humidity levels near saturation. Sunlight is required to drive the reaction in the presence of oxidants. It is also suspected that the $\mathrm{SO}_{2}$ is absorbed into the liquid phase prior to oxidation. This absorption is dependent on the $\mathrm{pH}$ of the liquid, the concentration of $\mathrm{SO}_{2}$, the surface area available for absorption, and the temperature. It has been stated that during the winter at latitudes between $37^{\circ}$ and $47^{\circ} \mathrm{N}$ (Kentucky/Virginia to northern Maine), the photochemical conversion rates would be less than 0.1 percent/hour. According to Altschuller (1980), "Such low winter rates would not be likely to contribute substantially to atmospheric sulfate 
loadings." 4 In the summer the conversion rate at these latitudes would be 0.25 percent to 0.4 percent/hour.

Removal of the transformed $\mathrm{SO}_{4}^{-2}$ species through neutralization, deposition, or combination with other pollutants is necessary for the photochemical reaction to continue. In the absence of such removal, the conversion will proceed only until equilibrium conditions are attained. Oxidation will proceed at a faster rate in the presence of catalysts. Several metal salts are suspected of promoting catalytic oxidation; these include manganese sulfate, manganese chloride, and copper sulfate. Sodium chloride also promotes catalytic oxidation, but at a much slower rate than the metal salts. 5

\section{A.2.2 Transport}

Ions produced during photochemical oxidation are present as very fine particulates (aerosols) of small mass. This aerosol can be transported over long distance in the upper atmosphere, with the prevailing winds. Factors affecting long-range transport are dependent on the transport properties of the air mass, and the height at which pollutants are emitted. Some air mass characteristics of importance are atmospheric stabilily, the height, intensity, and frequency of inversion layers, windspeed, and obstructions to transport (hills and mountains).

Studies of ambient air in the northeastern United States indicate some local transport as well. For example, Altschuller (1980) indicated that: 1) "The urban excess of sulfate over regional sulfate levels decreased during the first, second, and fourth quarters (of the year) approximately in proportion to 
decreases in sulfur oxide on a local scale at northeastern urban sites;" 4 2) "... consistently high pärticulate sulfate concentrations and low ratios (with sulfur dioxide) suggest very strong local primary emission sources of sulfate contributing most of the ambient air concentration of sulfate..."; 6 and 3 ) "It seems likely that the primary $\left(\mathrm{SO}^{-2}\right)$ emissions and other emission sources near a (monitoring) site on Manhattan could be responsible for the high values: "6 sampsnn (1980) statod that "In Albany, southerly wind flow, typified by a well mixed boundary layer and moderately strong winds, is consistently associated with higher suspended particulate: concentrations." 7 Rahn (1981) observed that "the overall association between high sulfate of summer and northeastern character of the aerosol of Naragansett suggests that the Northeast may well be a major source of the sulfate and acidity measured in Rhode Island, (and) episodes of transport from the Midwest are seen only in winter and in only 3 percent of the samples." 8

Based on past research, it appears that either range of transport is feasible. To add to the confusion, ozone, in the northeast as well as acid deposition, is suspected of being due to LRT. Figure A-1 shows that Primary NAAQS for this photochemically oxidized pollutant are not attained in much of the Midwest and Northeast and could conceivably be caused by LRT. Even though New York is surrounded by nonattainment areas, however, only the Hudson River Valley and a small area near Niagara within the state are designated as nonattainment areas. It seems contradictory that a nonattainment problem resulting 


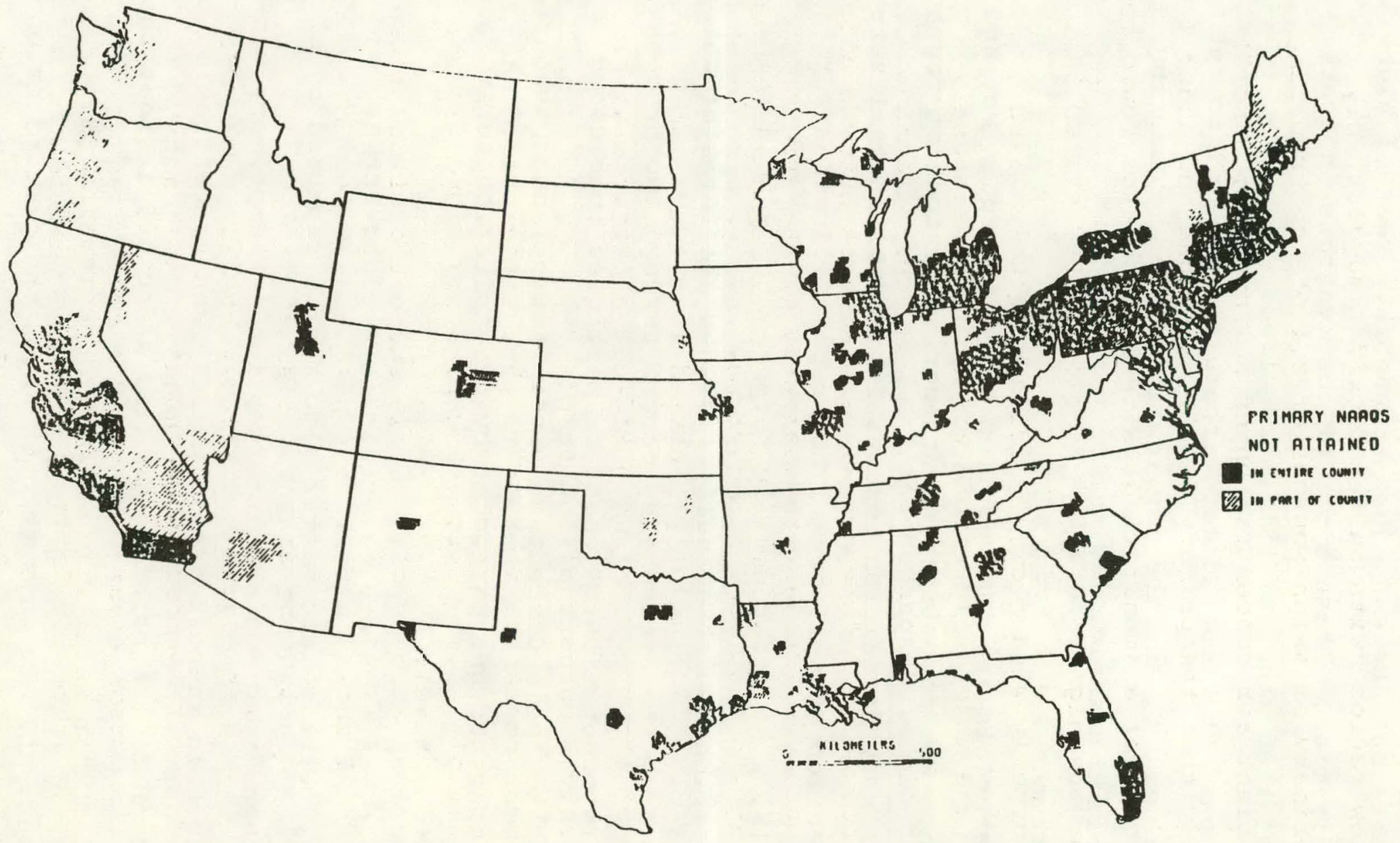

Figure A-1. Promulgated list of $0_{x}$ nonattaining counties - 1981. 
from LRT would not be present throughout an entire region such as New York state but instead just around the areas of highest industrial activities. These types of observations indicate that a more detailed study of LRT is required.

As these past studies indicate, there are many different theories of transport, and the implications of and reasoning behind them differ greatly.

\section{A.2.3 Deposition}

Acidic materials are removed from the air through wet and dry deposition. Wet deposition occurs during periods of fog and precipitation. Dry deposition results from gravitational settling and impaction on surfaces. This report addresses wet deposition only, i.e., that usually referred to as acid rain.

Wet deposition, which actually includes all forms of water that condense from the atmosphere, occurs through two processes: rainout (the incorporation of gases or particles into cloud droplets prior to their descent as precipitation) and washout (the removal of gases and particles by precipitation as it falls through the atmosphere).

In rainout, particulate materials in a cloud act as condensation nuclei. Particulate matter also may be captured by cloud droplets through impaction and interception. The primary controlling factors in rainout are solubility and concentration of the gas. The $\mathrm{pH}$ of the moisture is also a factor, in that the solubility of $\mathrm{SO}_{2}$ in water decreases with decreasing $\mathrm{pH}$.

In washout, the air mass through which the precipitation falls is cleansed as pollutants in the atmosphere are captured 
by impaction and interception. In light precipitation events, washout by absorption is also possible and is controlled by the same factors as in rainout. Otherwise, the surface area of the precipitation and the ambient concentrations of the pollutants are the main factors controlling pollutant washout.

Long-range transport is predominantly associated with the rainout mechanism, whereas short-range deposition can be associated with the washout mechanism. The relative importance of the two wet deposition mechanisms is unknown and no actual quantifications have been made to rank them.

\section{A. 3 SELECTION OF DATA ANALYSIS METHODS}

Many different methods (ranging from the very simple to the very sophisticated) have been used to explain the occurrence of acid rain in the United States. All of these methods fall into one of two general categories: 1) source-oriented methods and 2) receptor-oriented methods. Source-oriented methods assume that certain specific sources or source types are the major. contributors to acid deposition. Given this assumption and support information on emission rates, transport mechanisms, and deposition mechanisms, hypotheses are developed and tested to arrive at the contribution of the sources at various receptors. The methods most often used include LRT models incorporating transport, traneformation, and depletion functions, and comparisons of emission characteristics and suspected impact areas.

Receptor-oriented methods start with the measurement of a specific feature of a sample at the recoptor (sampling station). 
Either by inference or back calculation, the variation in the. available data provides a probable contribution from specific'. sources or source types. The methods most often used in the receptor-oriented approach include chemical/element mass balance, enrichment factor, time series correlation, multivariate analysis, and spatial correlation. In recent years these methods have been labeled as "receptor models," which implies the use oftult: some sophisticated relationships and input data manipulation to wi develop a "predictive model." Actually the term "model," as used in this context, is equivalent to an equation that is int: developed by using a least squares fitting technique on the data to arrive at what appears to be the best explanation of the behavior of a specific species noted at a sampling site, given the input assumptions used in the analysis. Thus, these models could be more correctly described as the application of the logic and assumptions offered to data analysis by simple statis-: tical analysis techniques.

Receptor-oriented methods can be very powerful tools. A combination of the source and receptor oriented methods forms the basis for analyses conducted in this study. The two general types used are time-series and spatial correlations.

\section{A.3.1 Time-Series Correlations}

The use of time-series correlations, or discerning temporal patterns, is popular for analyzing receptor information. Longterm trends, short-term trends, monthly or seasonal averages, and other time-series correlations are common. Analysis results are interpreted by comparing the emission trends of sources over 
the same temporal period to identify similar trends. Other variables also can be considered if they follow a pronounced temporal pattern, e.g., temperature, wind direction, and precipitation amounts.

Time-series correlation offers a positive analytical tool because both the deposition of the various constituents in a wet deposition sample and meteorological conditions vary as a function of season. Being able. to explain the seasonal variation of the acid deposition by definitive knowledge of the behavior of the various meteorological variables, coupled with an understanding of the sources of emissions and seasonal variations of the emission of various pollutants, can provide a reasonable explanation of the observed seasonal variation in acid deposition rates.

Time-series correlations provide qualitative information that can form the basis for strong inferences as to possible sources and effects of control measures, but they cannot provide quantitative information for specific source types. Nevertheless, this method provides unique qualitative information that is useful in evaluating the impact of control programs, direct-. ing the search for new sources, and confirming identified sources suggested by other methods. 8

The time-series correlation performed in this study first evaluates an entire set of data for a particular area. These data are then sorted into groups based on seasons for additional analysis. Two basic groupings have been chosen--one based on months requiring fuel consumption for space heating, and one 
based on months displaying similar monthly prevailing surface wind directions. Although not the classic seasonal splits, these groupings provide distinct subsets of the entire available data base.

\section{A.3.2 Spatial Correlations}

In the spatial correlation technique, comparisons are made of the measured deposition rates for various samples taken simultaneously at a number of different receptor sites. Implications of source contributions are obtained by comparing the spatial distributions of several selected species with the composition of emissions from specific sources or source categories. Common methods of spatial correlations include isopleths, intersite correlations, cluster analysis, pollution and wind roses, upwind-downwind analysis, and backwards trajectories.

Spatial correlations have been used most often where it is possible to identity areas that are impacted by unique source types and thus would be identifiable by comparing the observed species at various sites. Because the occurrence of acid deposition is ubiquitous, the application of spatial correlations to ascertain source contributions is considerably more complex than such application in an area impacted by a unique source. Therefore it is necessary to define the control volume or the volume of air assumed to be able to impact on a certain receptor. It is possible to formulate hypotheses for the application of spatial correlation methods that evaluate either the long-range transport or the local source theory. In either 
test, the resulting conclusions are qualitative and strongly dependent on the meteorological and emission variables affecting deposition during the period of sample collection.

A. 4 PRESENTATION OF WET DEPOSITION ANALYSIS RESULTS

Figures A-2 through A-25 summarize mean deposition rates, intersite correlations, and analysis of variance (ANOVA), for $\mathrm{SO}_{4}{ }^{-2}, \mathrm{NO}_{3}{ }^{-}, \mathrm{Ca}^{+2}$, and $\mathrm{Cl}^{-}$in each of the three study areas. These results support the discussion of results presented in Section 4 . 


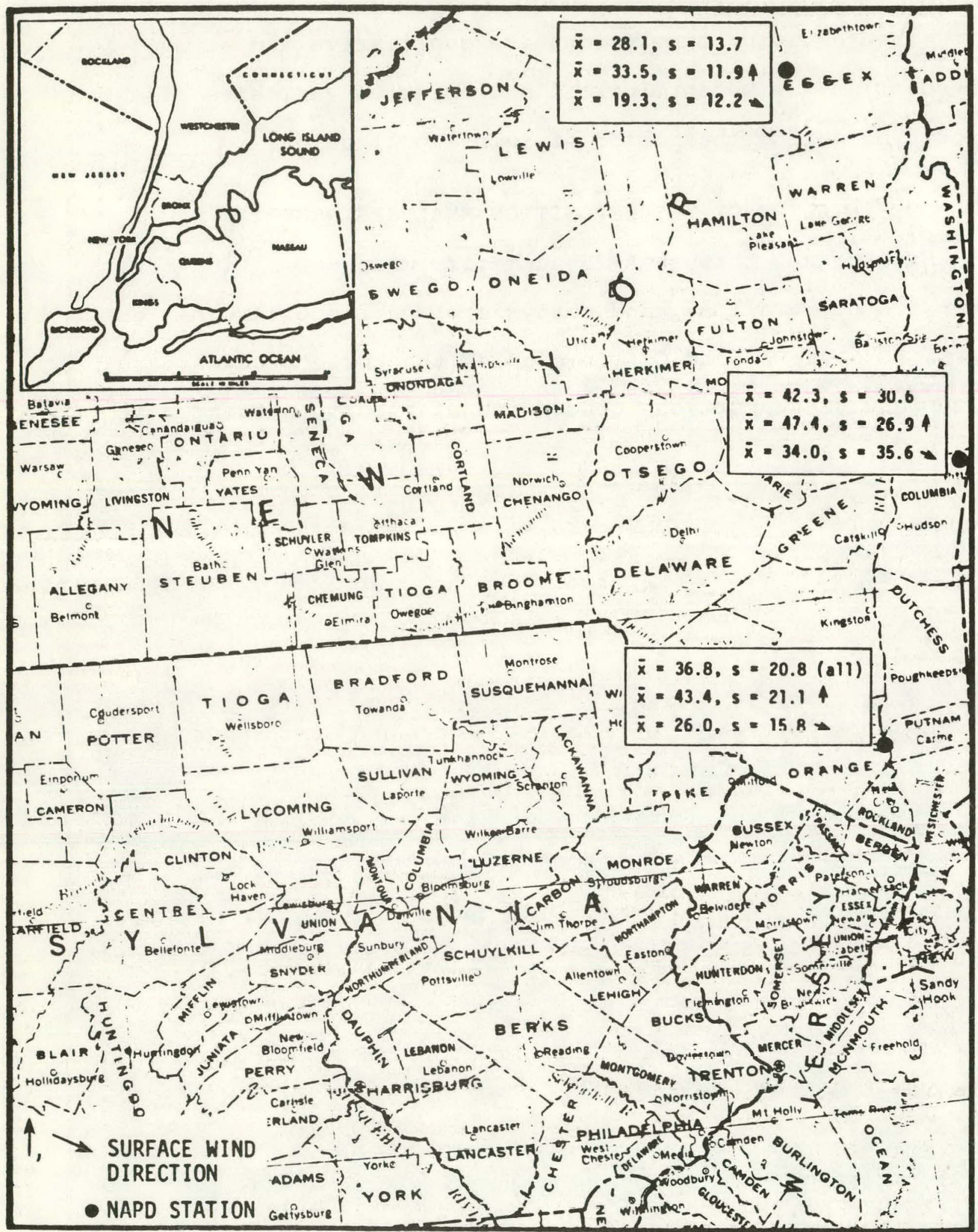

Figure $\mathrm{A}-2$. Mean $\mathrm{SO}_{4}^{-2}$ deposition rates $\left(\mathrm{mg} / \mathrm{m}^{2} / \mathrm{cm}\right.$ of $\mathrm{ppt}$ ) and standard deviations for selected data sets - New York area. 


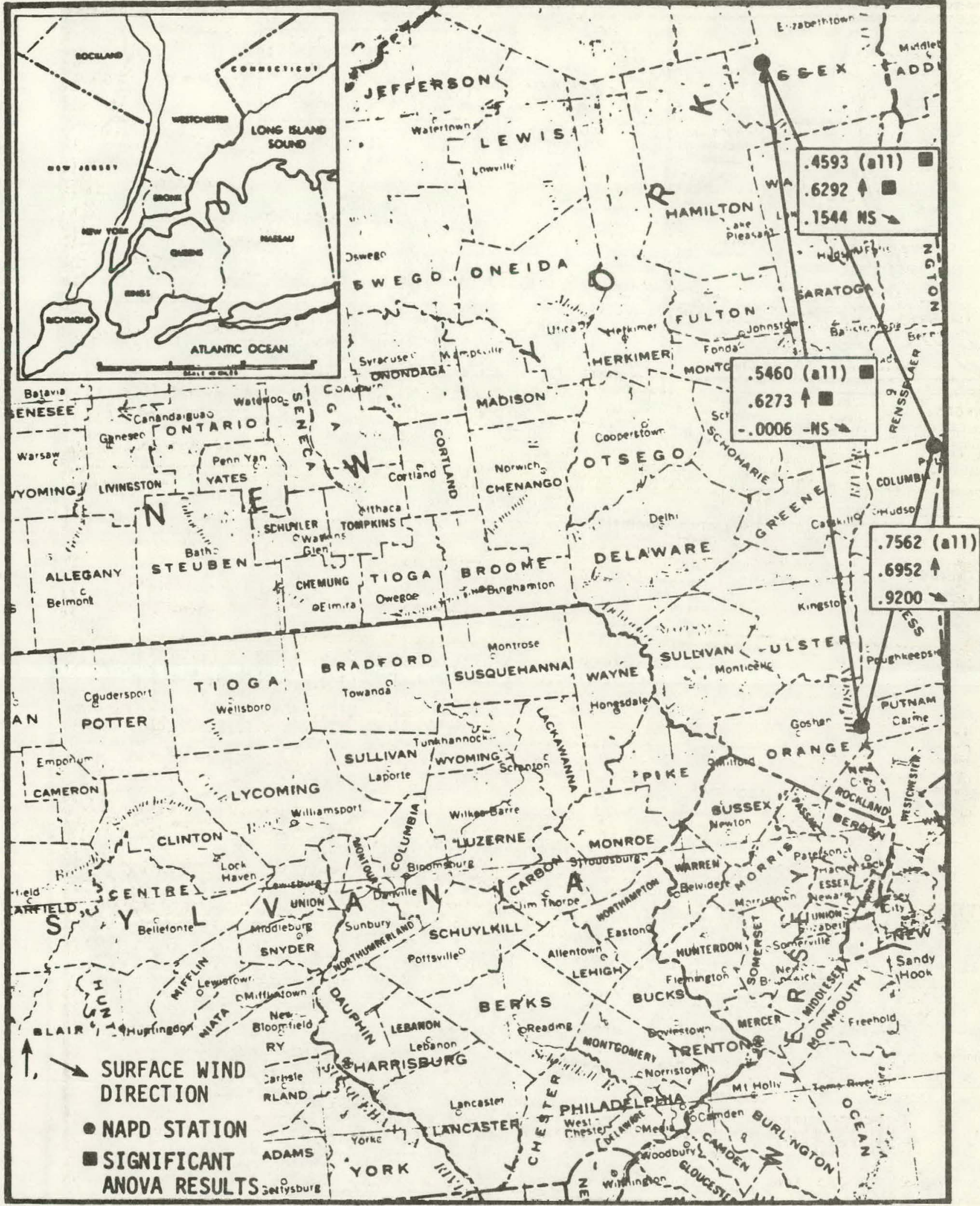

Figure A-3. Intersite correlation coefficients $(r)$ on $\mathrm{SO}_{4}^{-2}$ deposition rates $\left(\mathrm{mg} / \mathrm{m}^{2} / \mathrm{cm}\right.$ of $\left.\mathrm{ppt}\right)$ for selected data sets - New York area. 


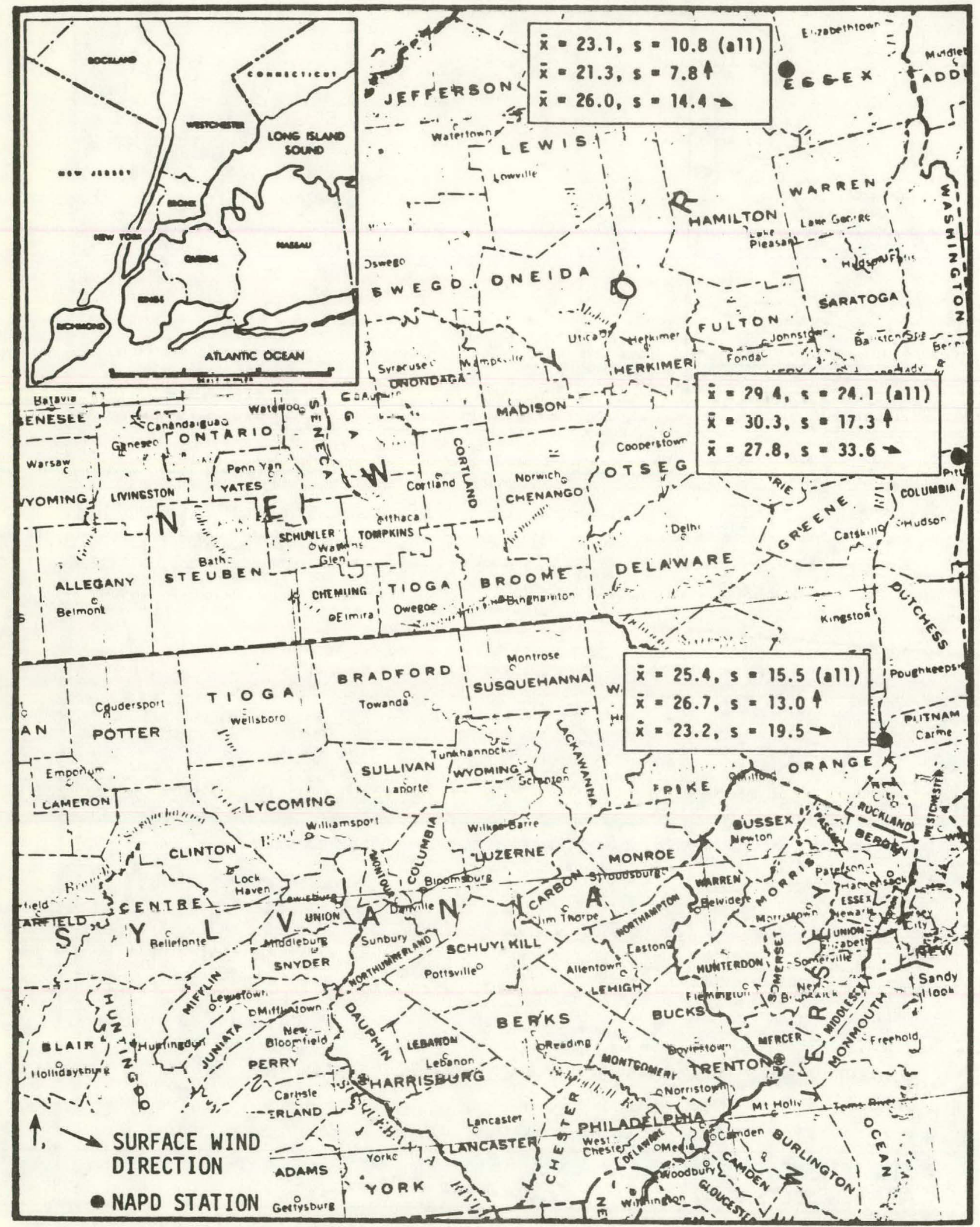

Fiaure A-4. Mean $\mathrm{NO}_{3}{ }^{-}$deposition rates $\left(\mathrm{mg} / \mathrm{m}^{2} / \mathrm{cm}\right.$ of $\mathrm{ppt}$ ) and standard deviations for selected data sets - New York area. 


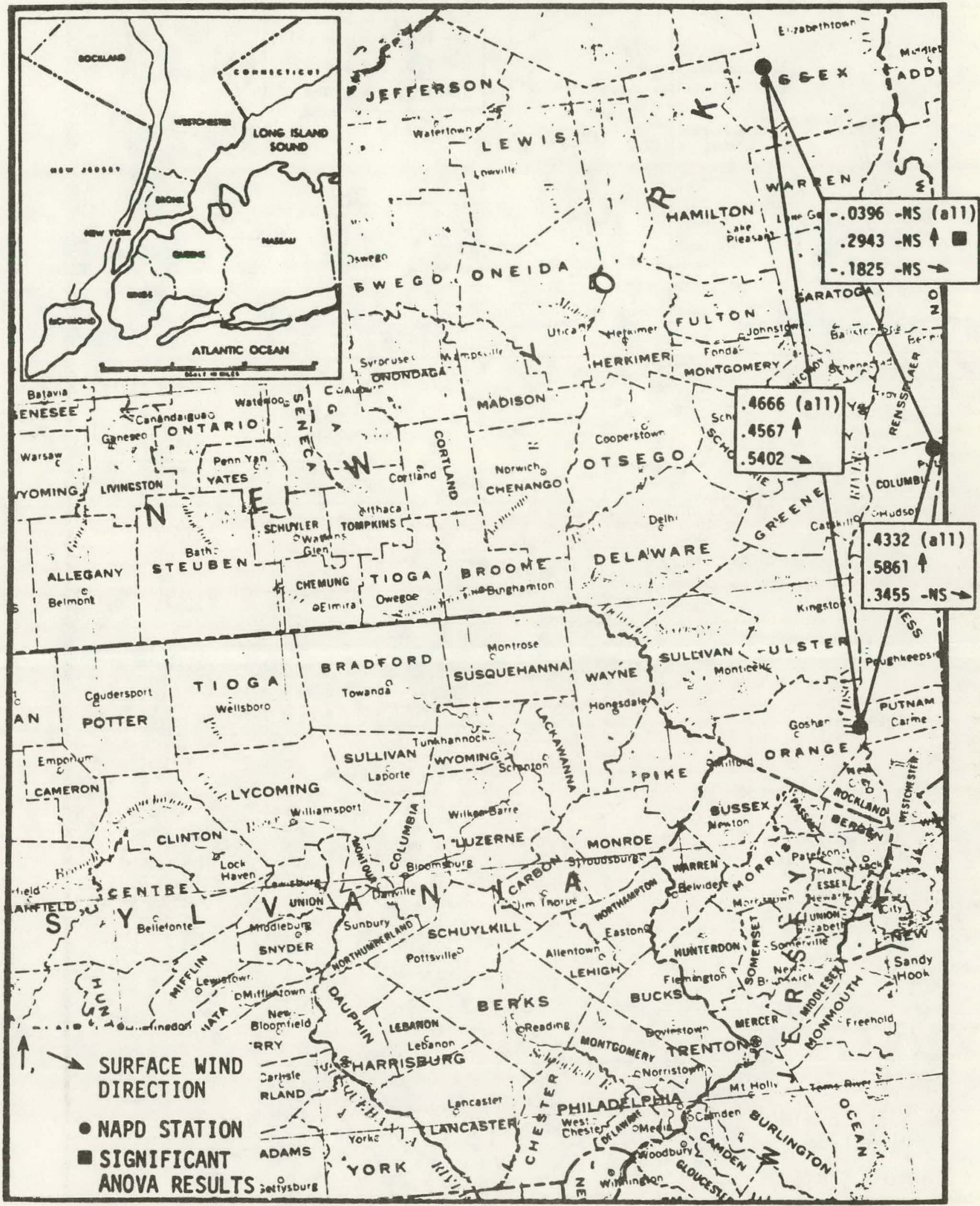

Figure A-5. Intersite correlation coefficients $(r)$ on $\mathrm{NO}_{3}{ }^{-}$deposition rates for selected data sets - New York area. 


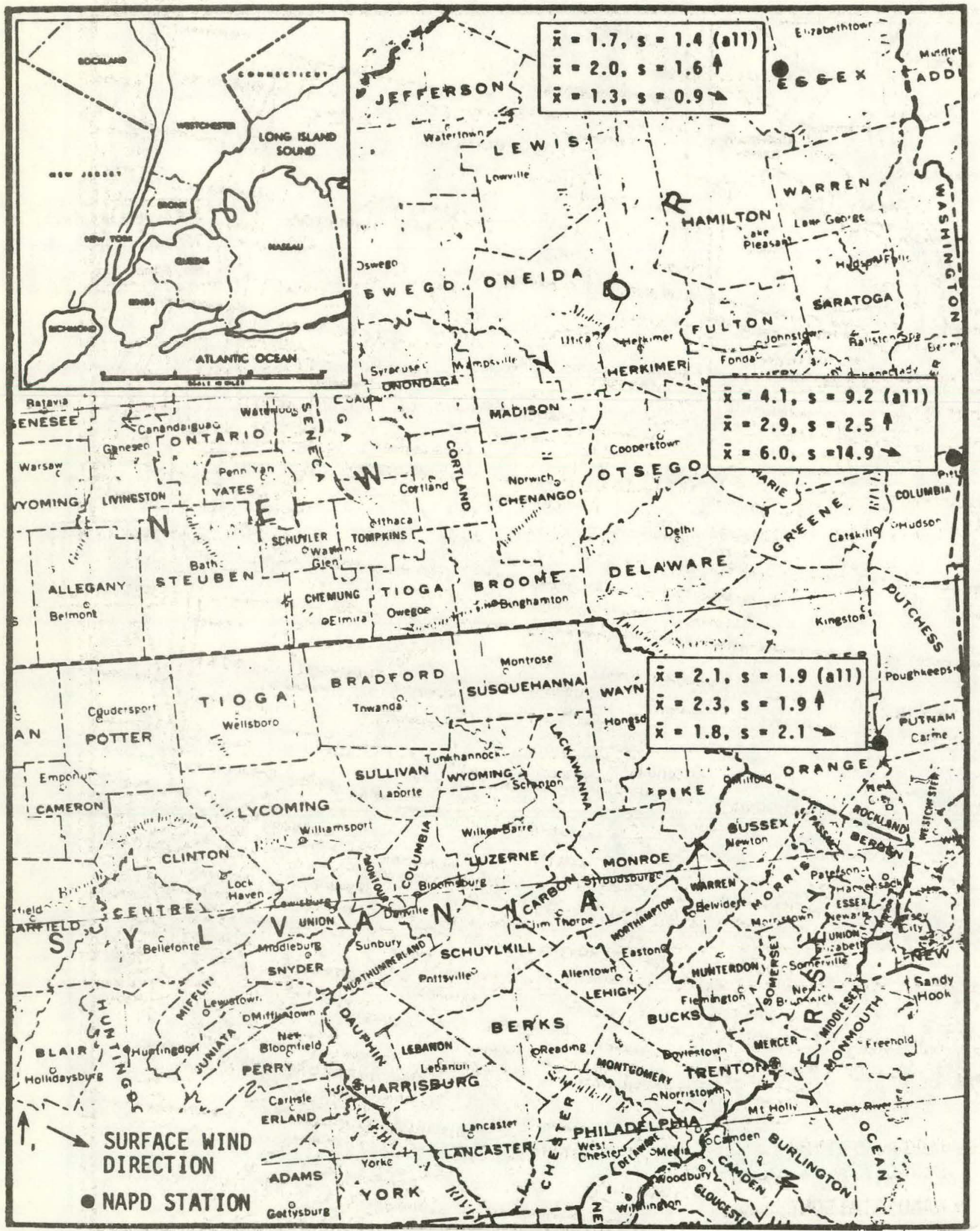

Figure A-6. Mean calcium deposition rates $\left(\mathrm{mg} / \mathrm{m}^{2} / \mathrm{cm}\right.$ of $\mathrm{ppt}$ ) and standard deviations for selected data sets - New York area. 


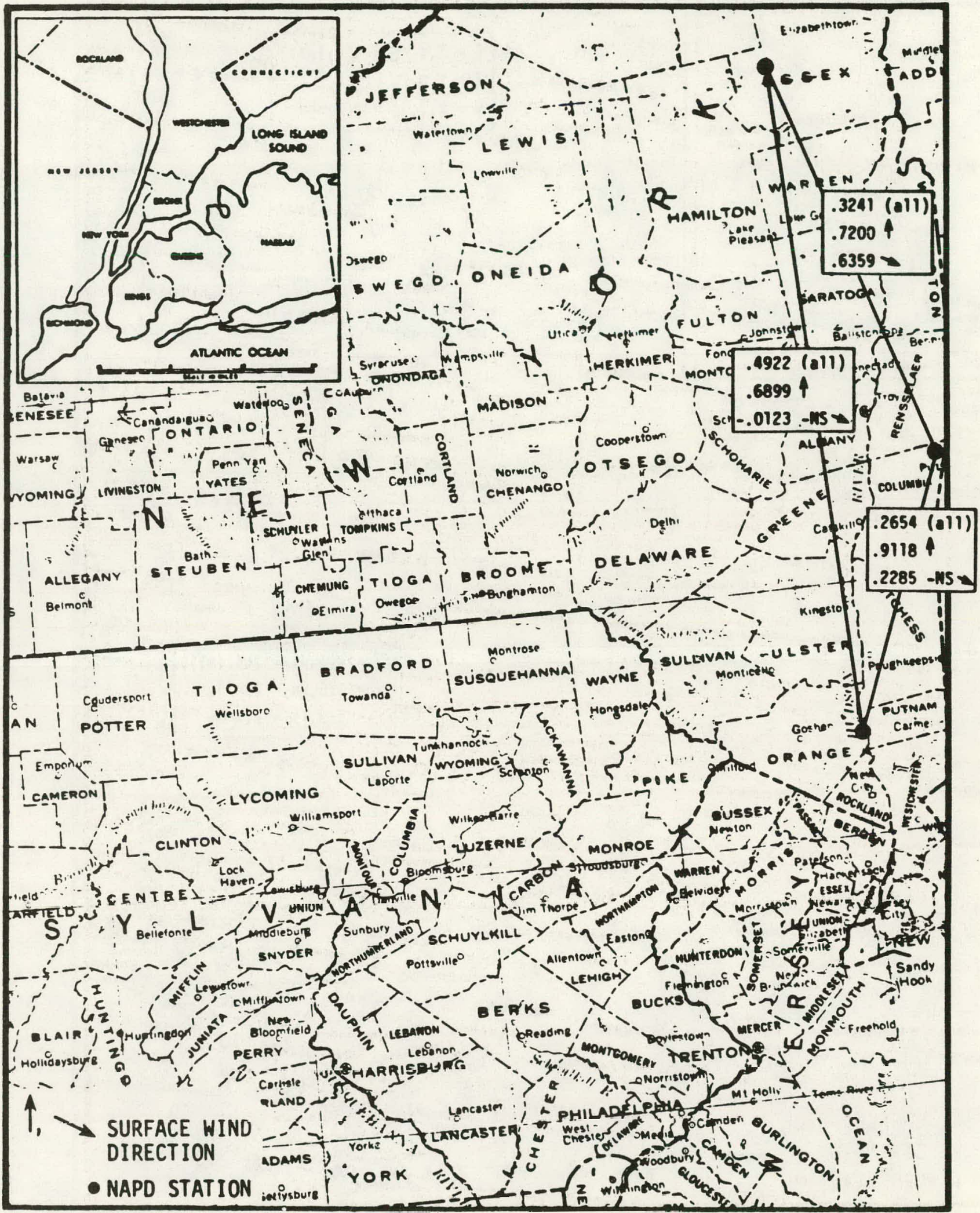

Figure A-7. Intersite correlation coefficients $(r)$ on calcium deposition rates $\left(\mathrm{mg} / \mathrm{m}^{2} / \mathrm{cm}\right.$ of $\left.\mathrm{ppt}\right)$ for selected data sets - New York area. 


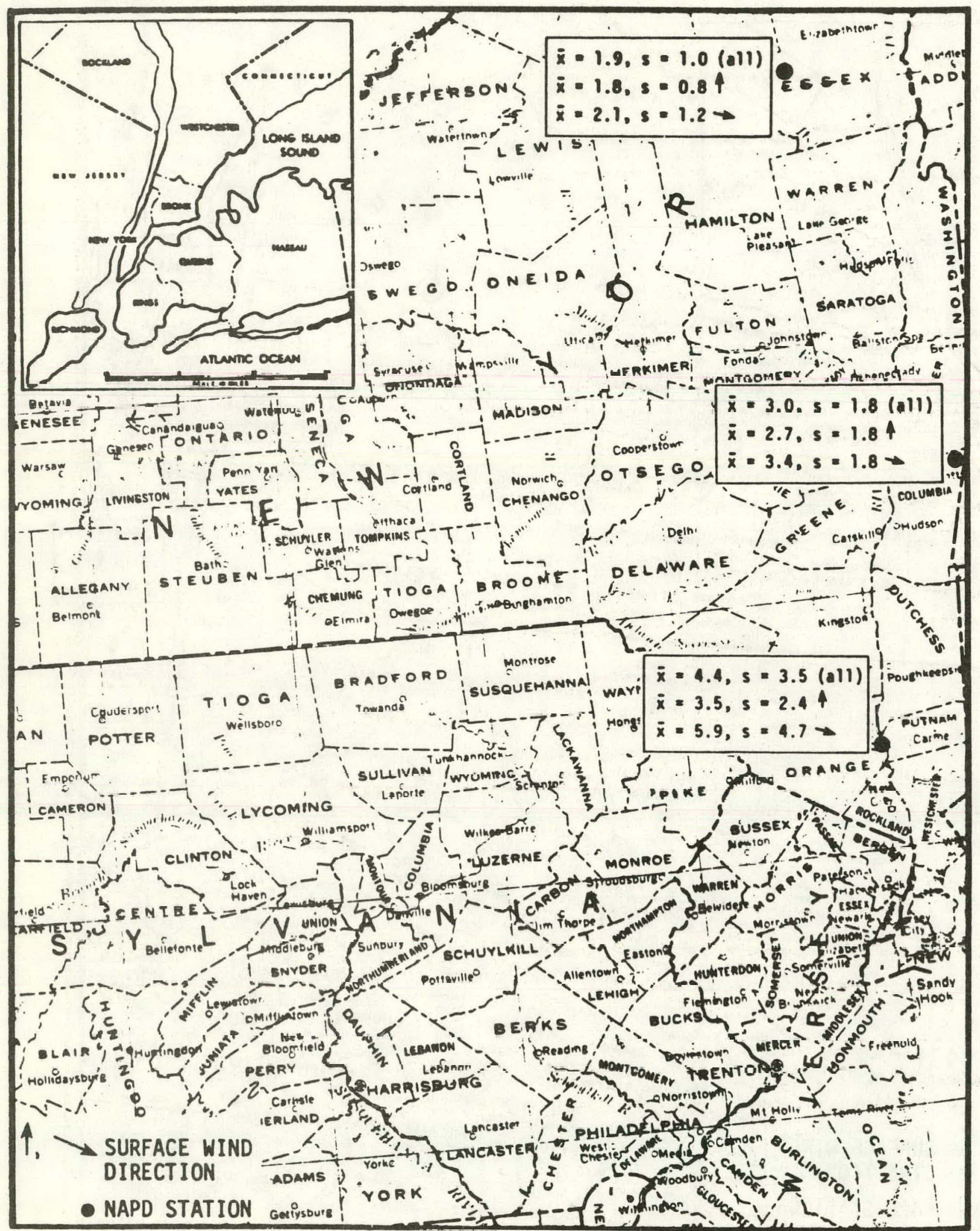

Fiqure A-8. Mean chloride deposition rates $\left(\mathrm{mg} / \mathrm{m}^{2} / \mathrm{cm}\right.$ of $\mathrm{ppt}$ ) and standard deviations for selected data sets - New York area. 


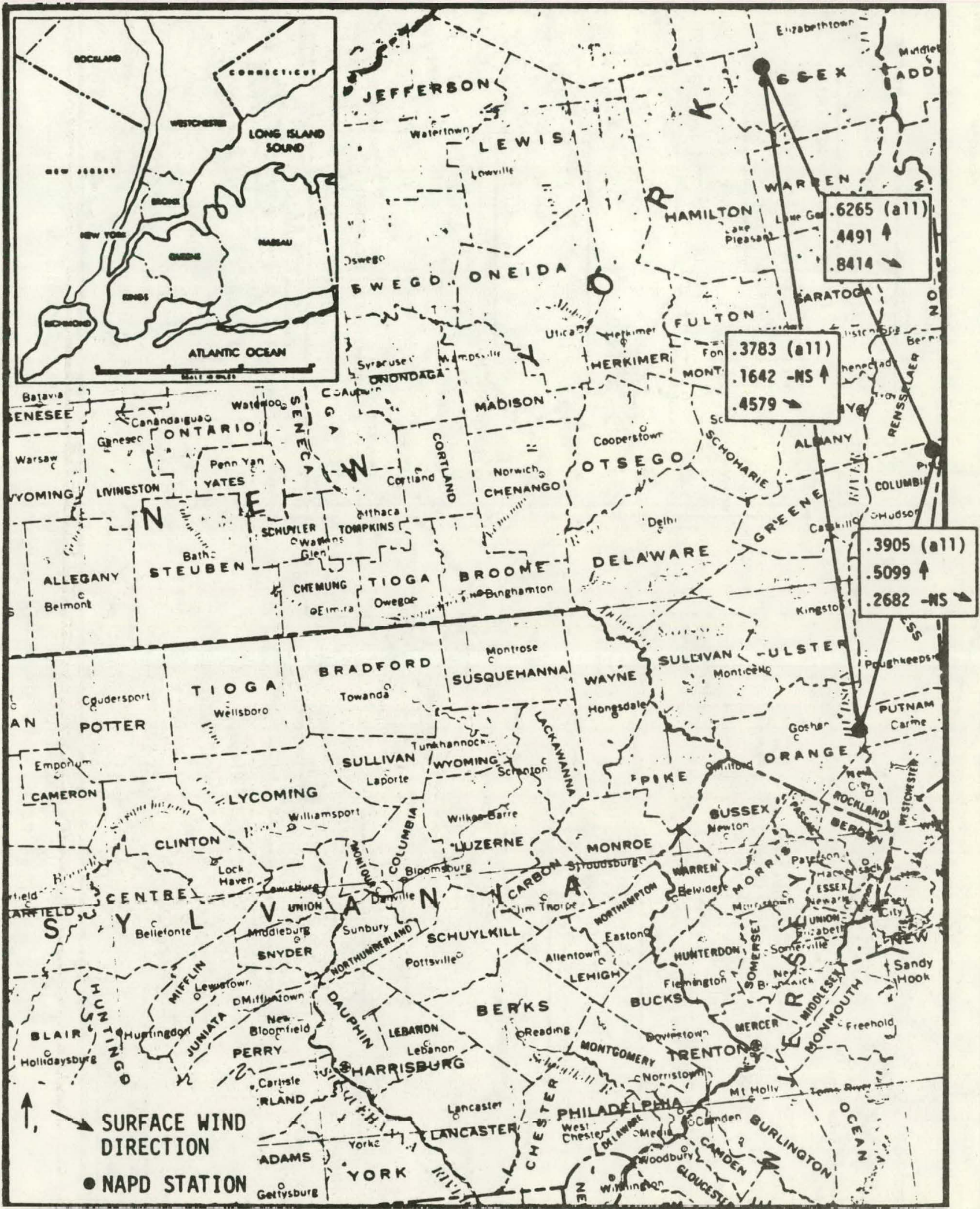

Figure A-9. Intersite correlation coefficients $(r)$ on chloride deposition rates $\left(\mathrm{mg} / \mathrm{m}^{2} / \mathrm{cm}\right.$ of $\left.\mathrm{ppt}\right)$ for selected data sets - New Y York area. 


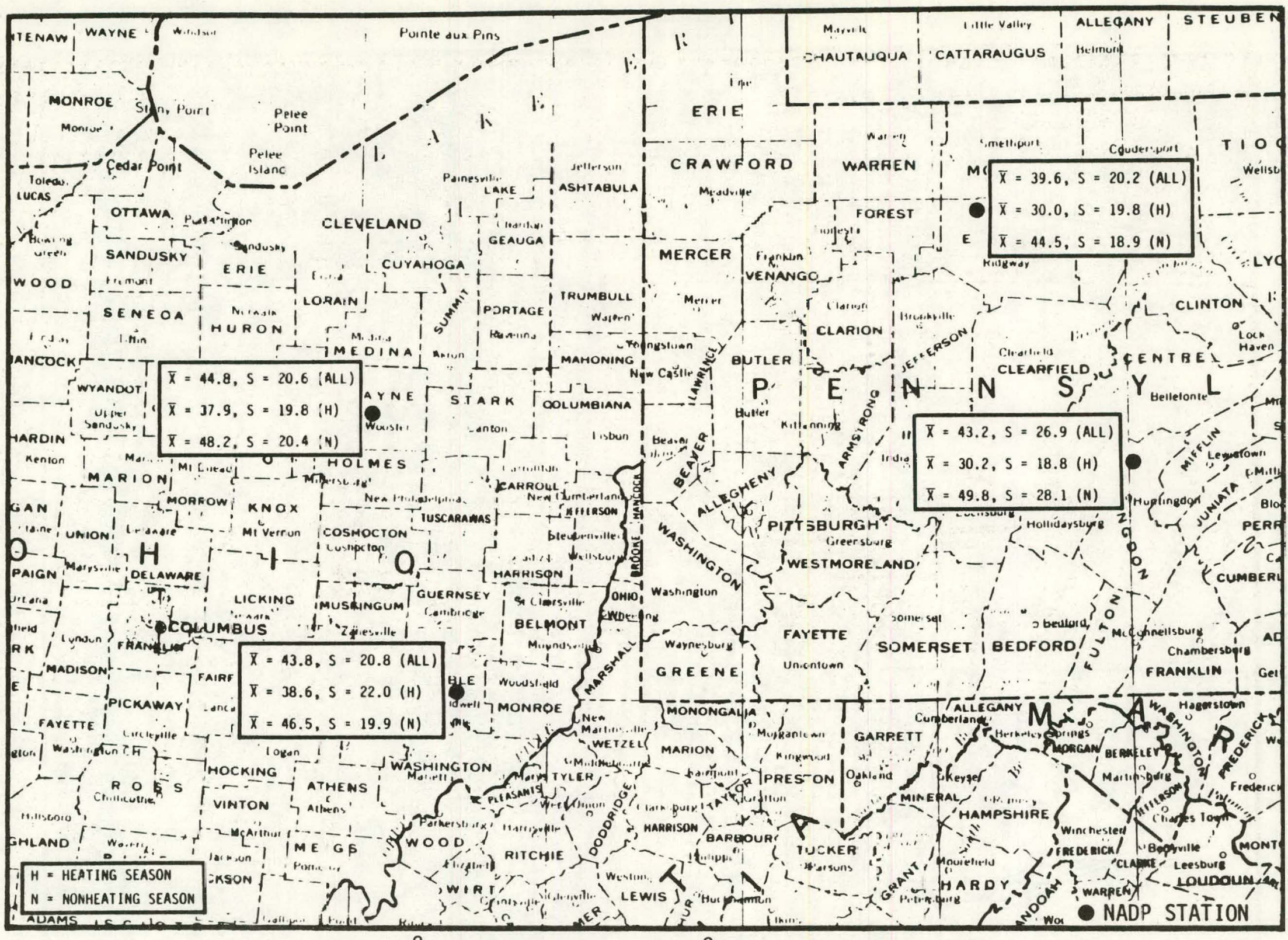

Figure $\mathrm{A}-10$. Mean $\mathrm{SO}_{4}^{-2}$ deposition rates $\left(\mathrm{mg} / \mathrm{m}^{2} / \mathrm{cm}\right.$ of $\mathrm{Fpt}$ ) anc standard deviations for sêlected data sets - Ohio/Pennsylvania area. 


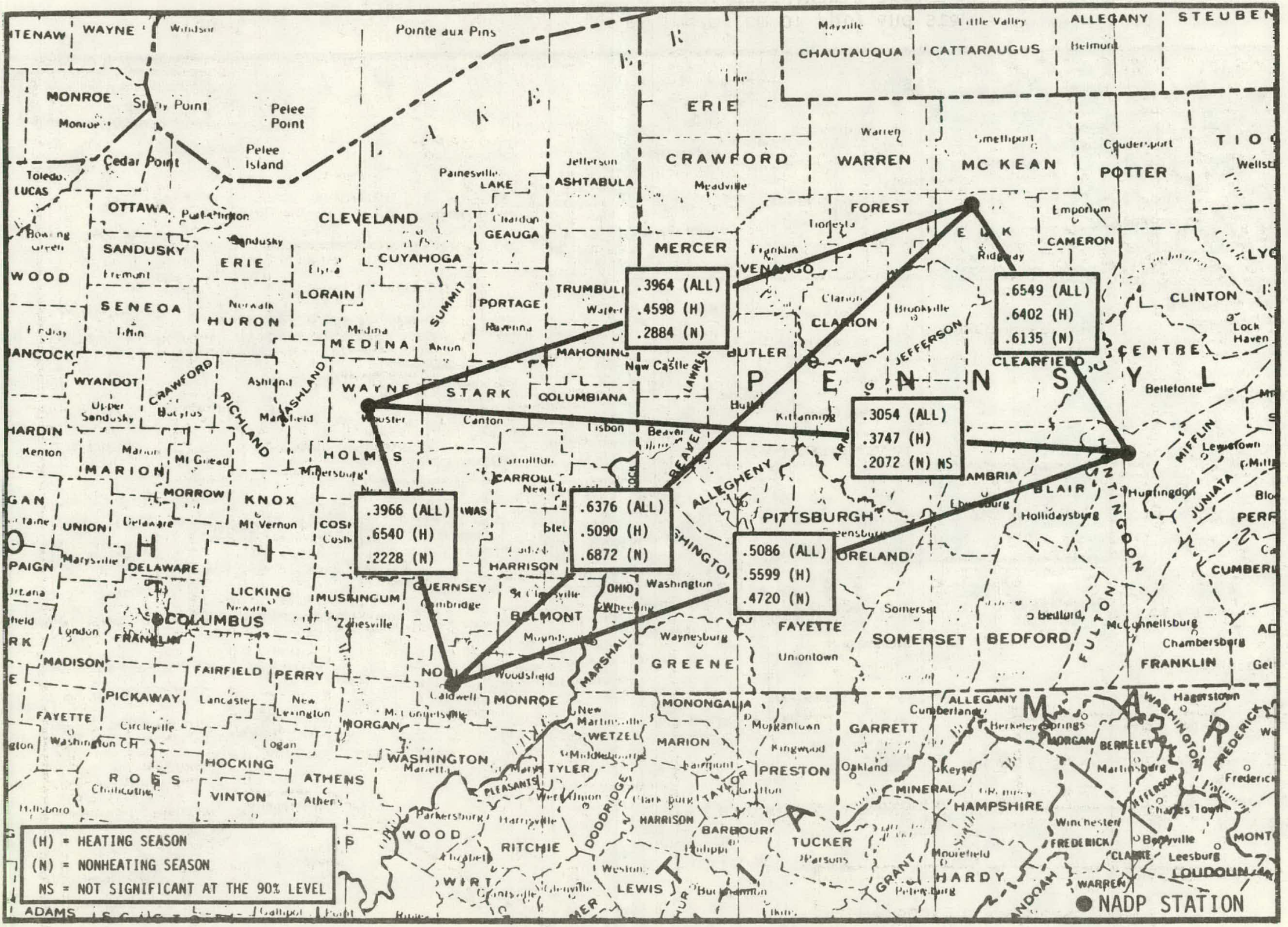

Figure A-11. Intersite correlation coefficients $(r)$ on $\mathrm{SO}_{4}^{-2}$ deposition rates $\left(\mathrm{mg} / \mathrm{m}^{2} / \mathrm{cm}\right.$ of ppt) for selected data sets - Ohio/Pennsylvania area. 


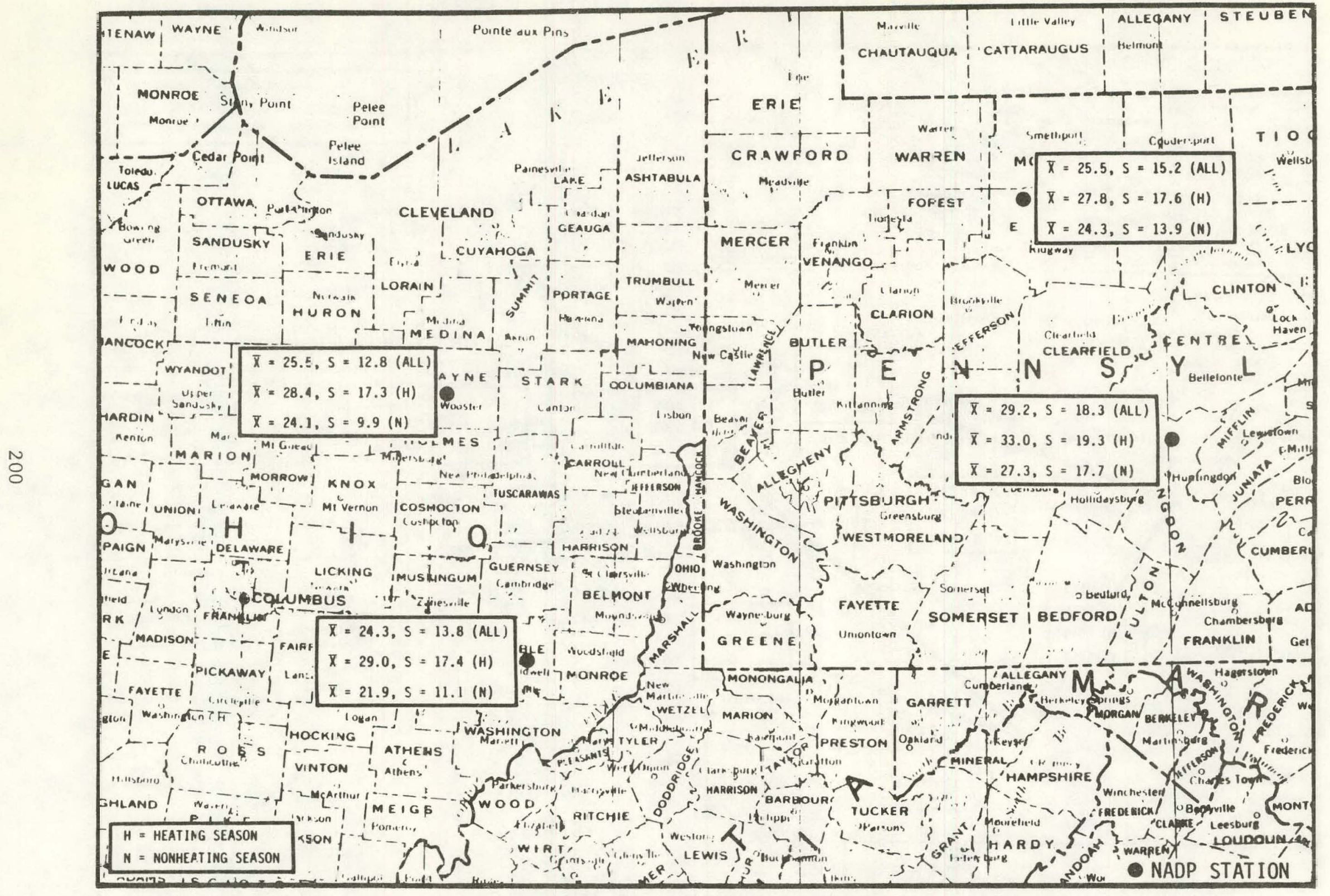

Figure $\mathrm{A}-12$. Mean $\mathrm{NO}_{3}{ }^{-}$deposition rates $\left(\mathrm{mg} / \mathrm{r}^{2} / \mathrm{cm}\right.$ of $\mathrm{ppt}$ ) and standard deviations for selected data sets - Ohic/Pennsylvania area. 


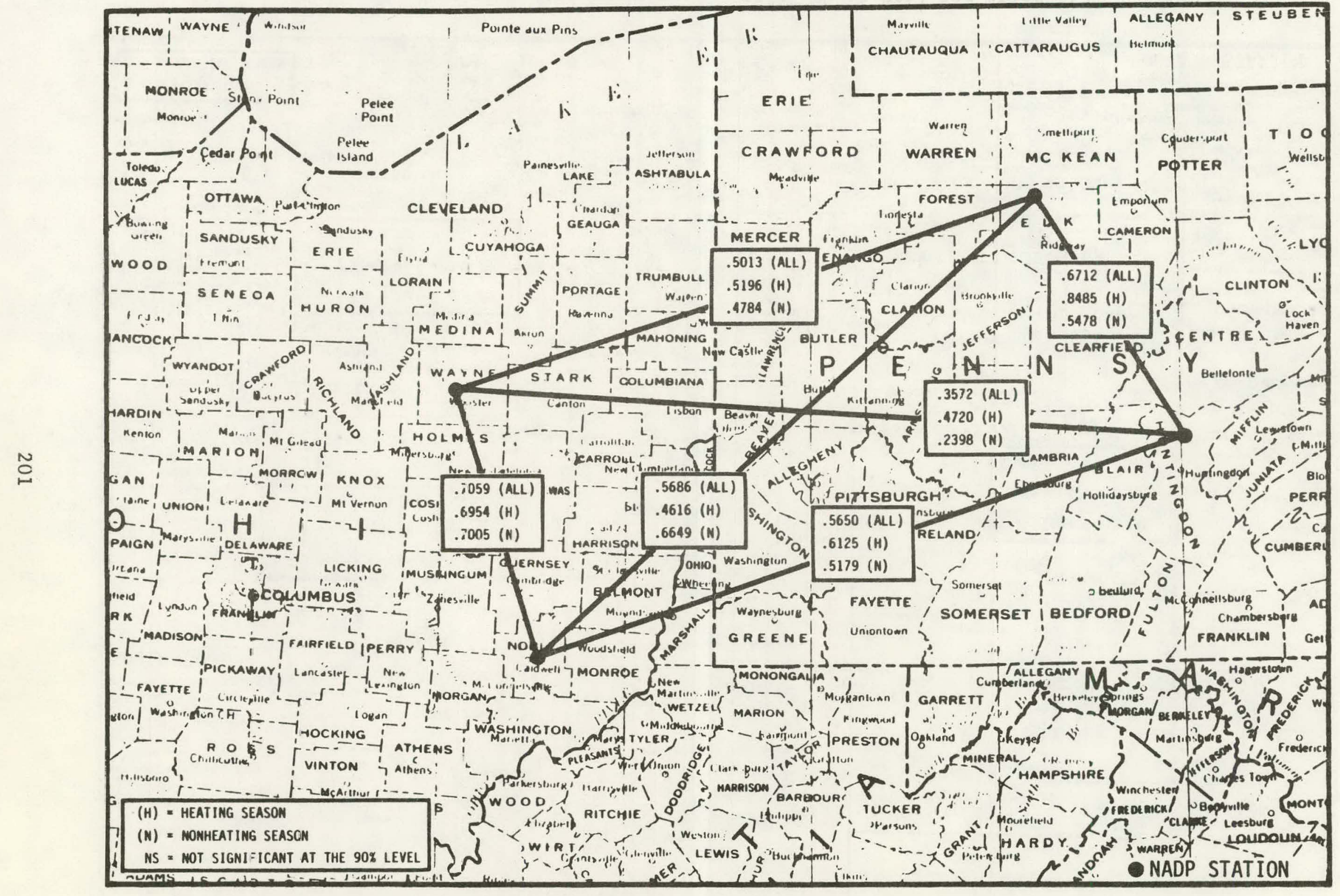

Figure A-13. Intersite correlation coefficients $(r)$ on $\mathrm{NO}_{3}{ }^{-}$deposition rates $\left(\mathrm{mg} / \mathrm{m}^{2} / \mathrm{cm} \mathrm{of} \mathrm{ppt}\right)$ for selected data sets - Ohio/Pennsylvania area. 


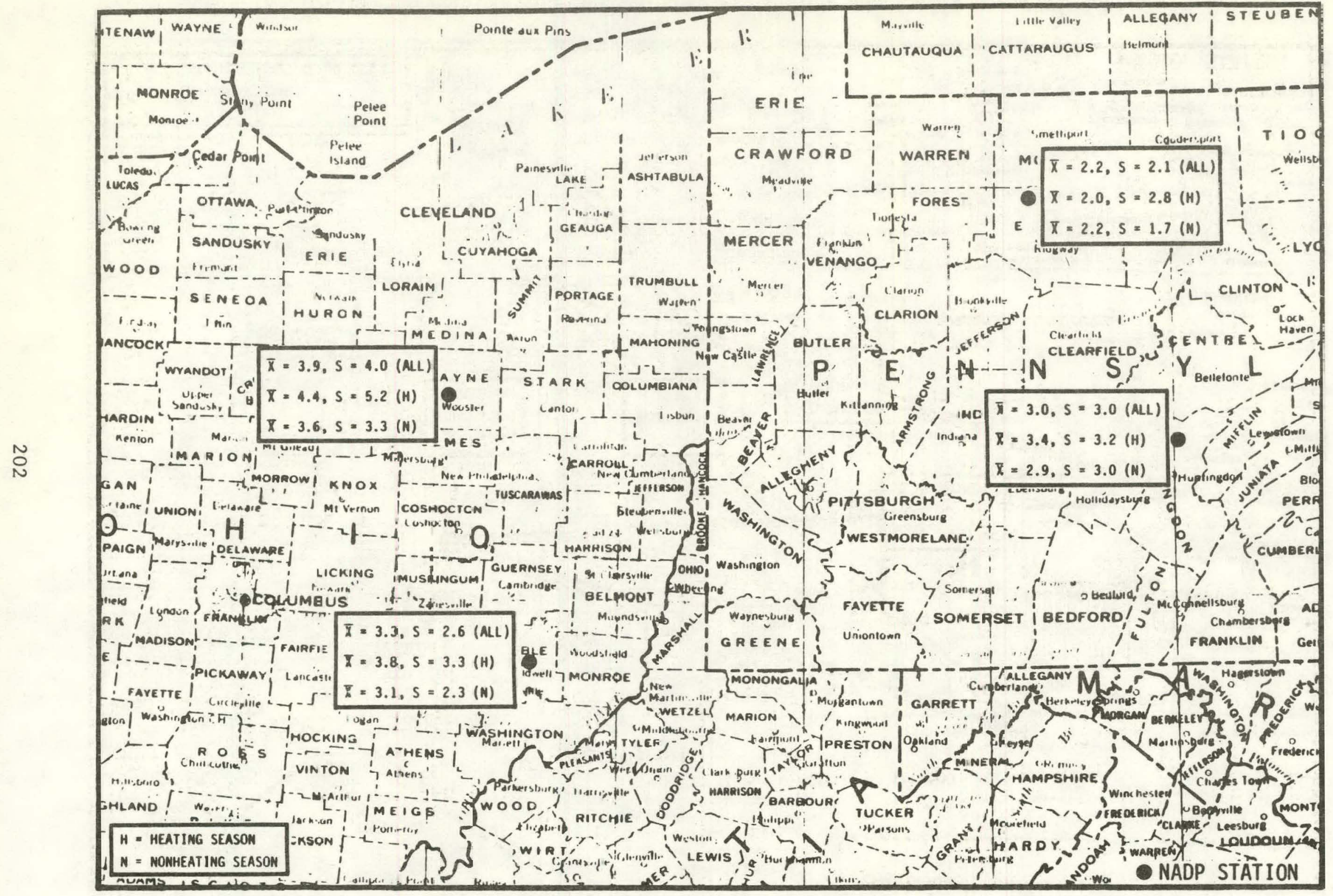

Figure A-14. Mean calcium deposition rates $\left(\mathrm{mg} / \mathrm{m}^{2} / \mathrm{cm}\right.$ of $\mathrm{ppt}$ ) and standard deviations for selected data sets - Ohio/Pennsylvania area. 


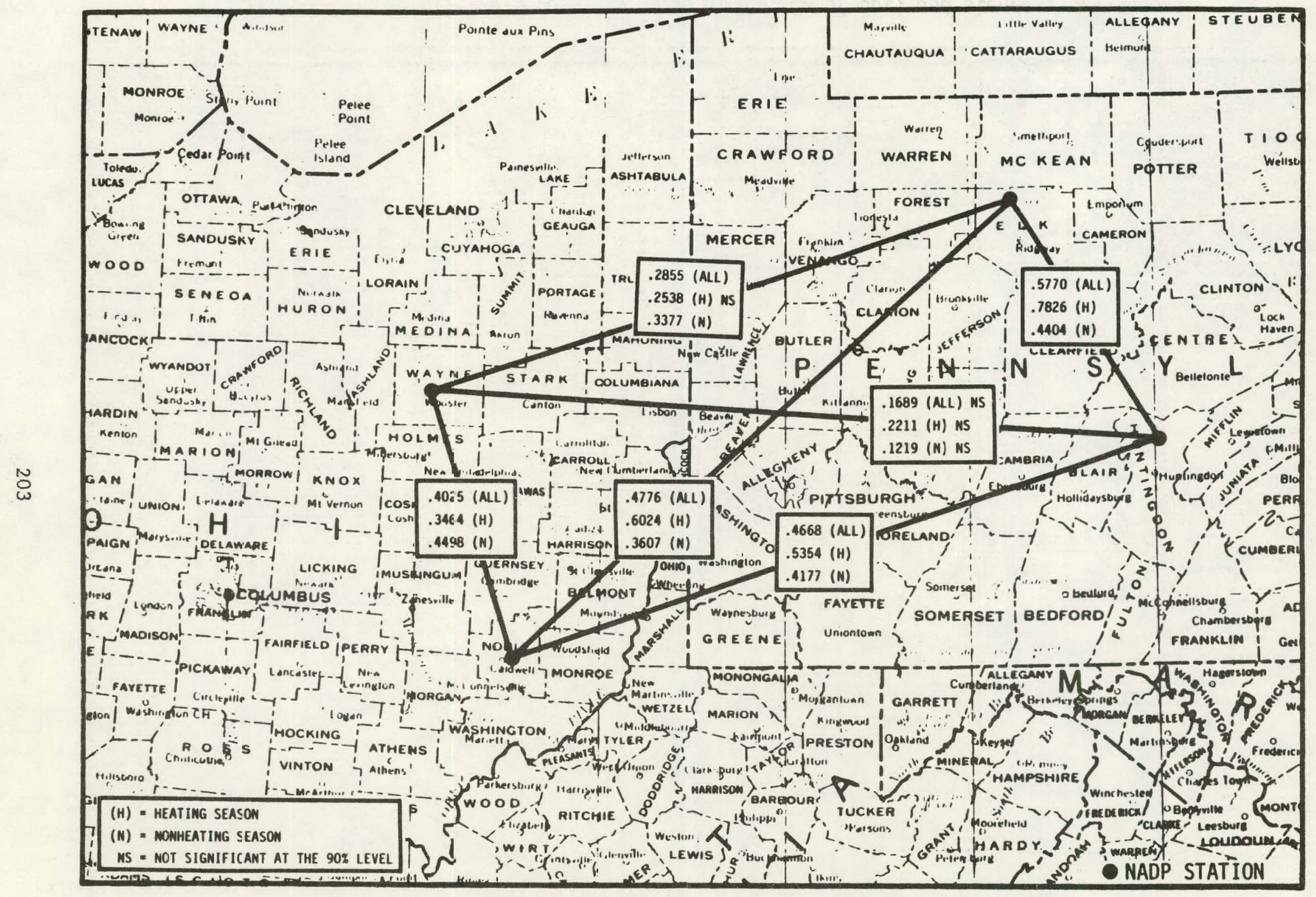

Figure A-15. Intersite correlation coefficients $(r)$ on calcium deposition rates $\left(\mathrm{mg} / \mathrm{m}^{2} / \mathrm{cm}\right.$ of ppt) for selected data sets - Ohio/Pennsyivania area. 


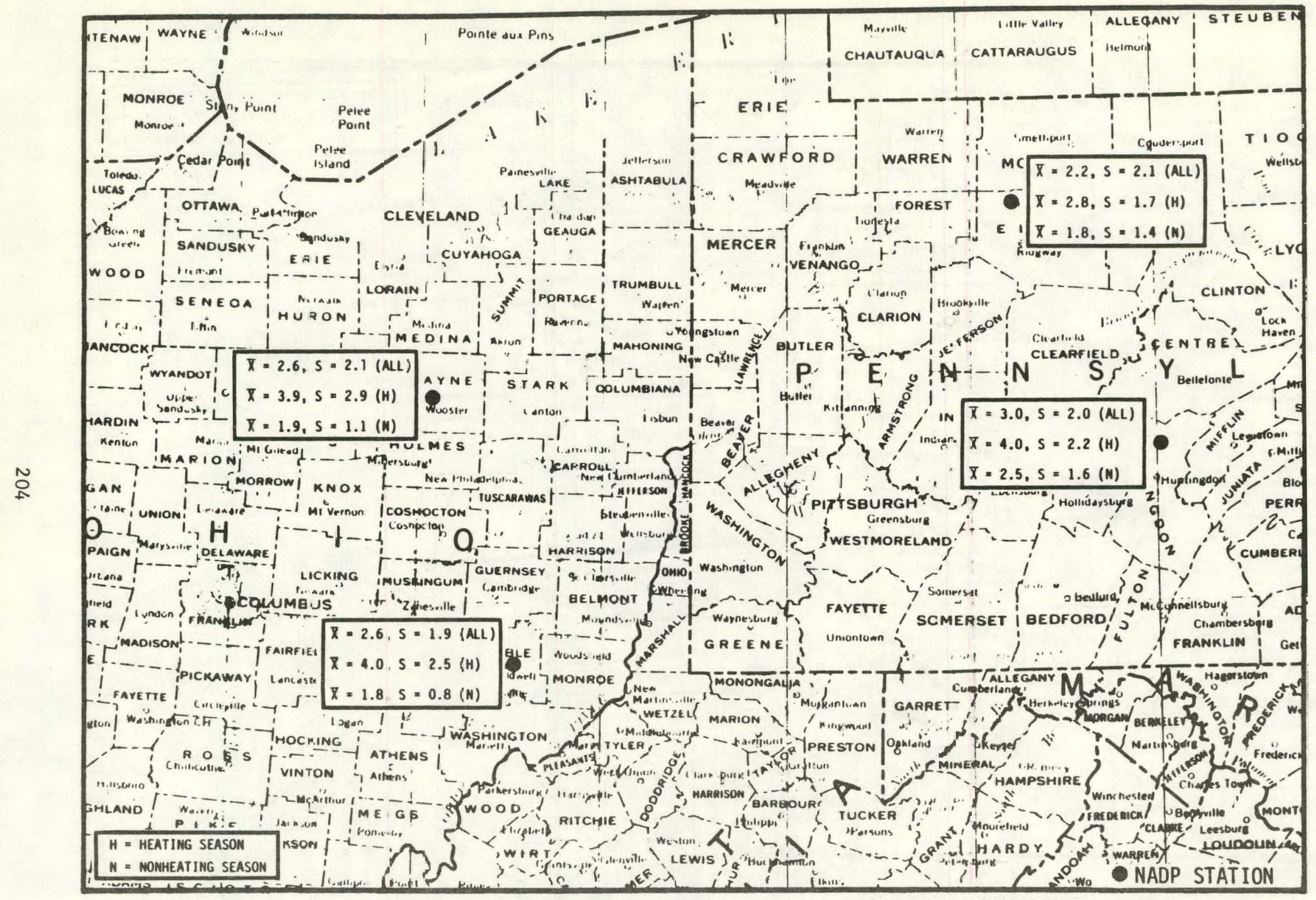

Figure A-16. Mean chloride deposition rates $\left(\mathrm{mg} / \mathrm{m}^{2} / \mathrm{cm}\right.$ of $\mathrm{ppt}$ ) and standard deviations for selected data sets - Ohio/Pennsylvania area. 


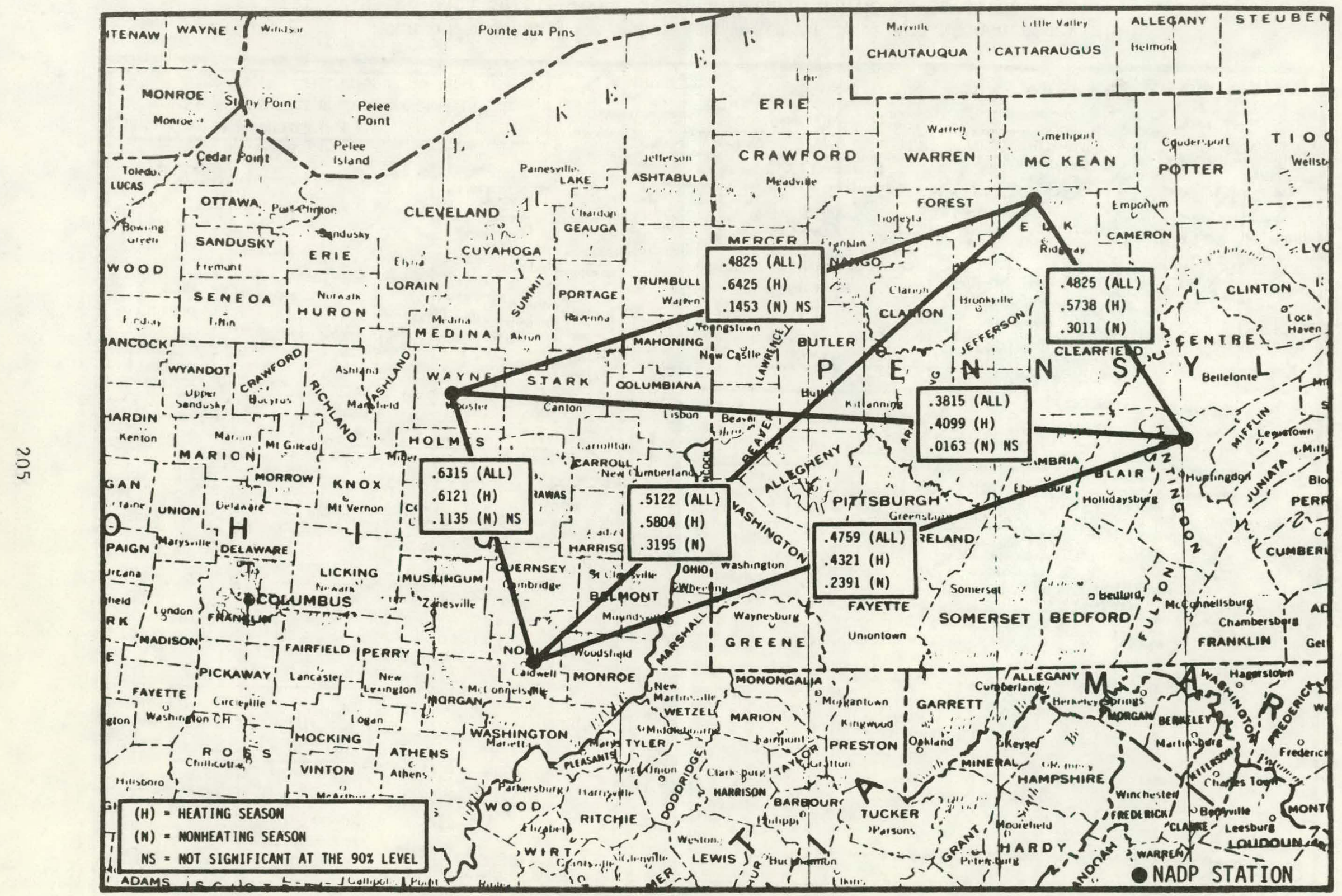

Figure A-17. Intersite correlation coefficients $(r)$ on chloride deposition rates $\left(\mathrm{mg} / \mathrm{m}^{2} / \mathrm{cm}\right.$ of $\mathrm{ppt}$ ) for selected data sets - Ohio/Pennsylvania area. 


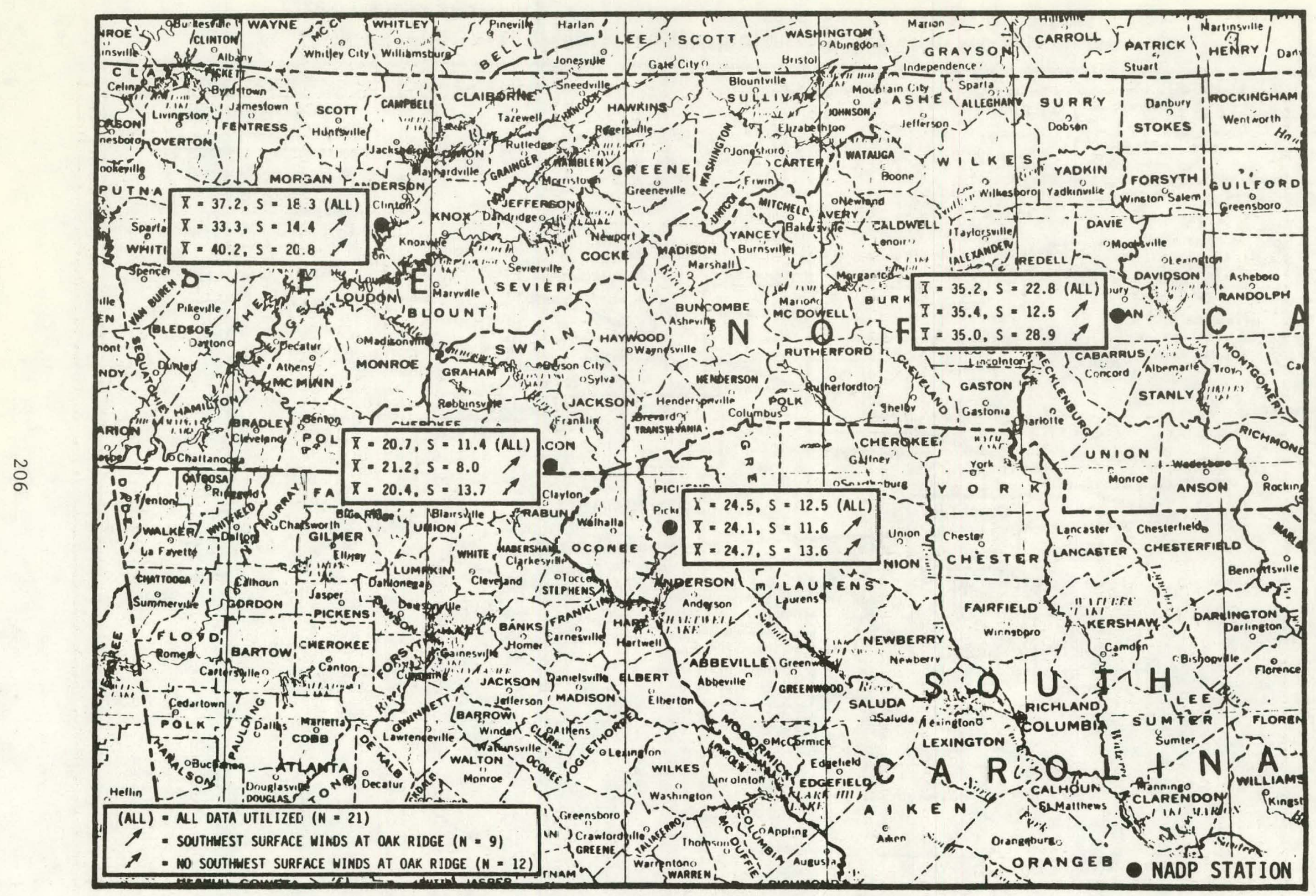

Figure A-18. Mean $\mathrm{SO}_{4}^{-2}$ deposition rates $\left(\mathrm{mg} / \mathrm{m}^{2} / \mathrm{cm}\right.$ of $\mathrm{ppt}$ ) and standard deviations for selected data sets - Tennessee/South Carolina/North Carolina area. 


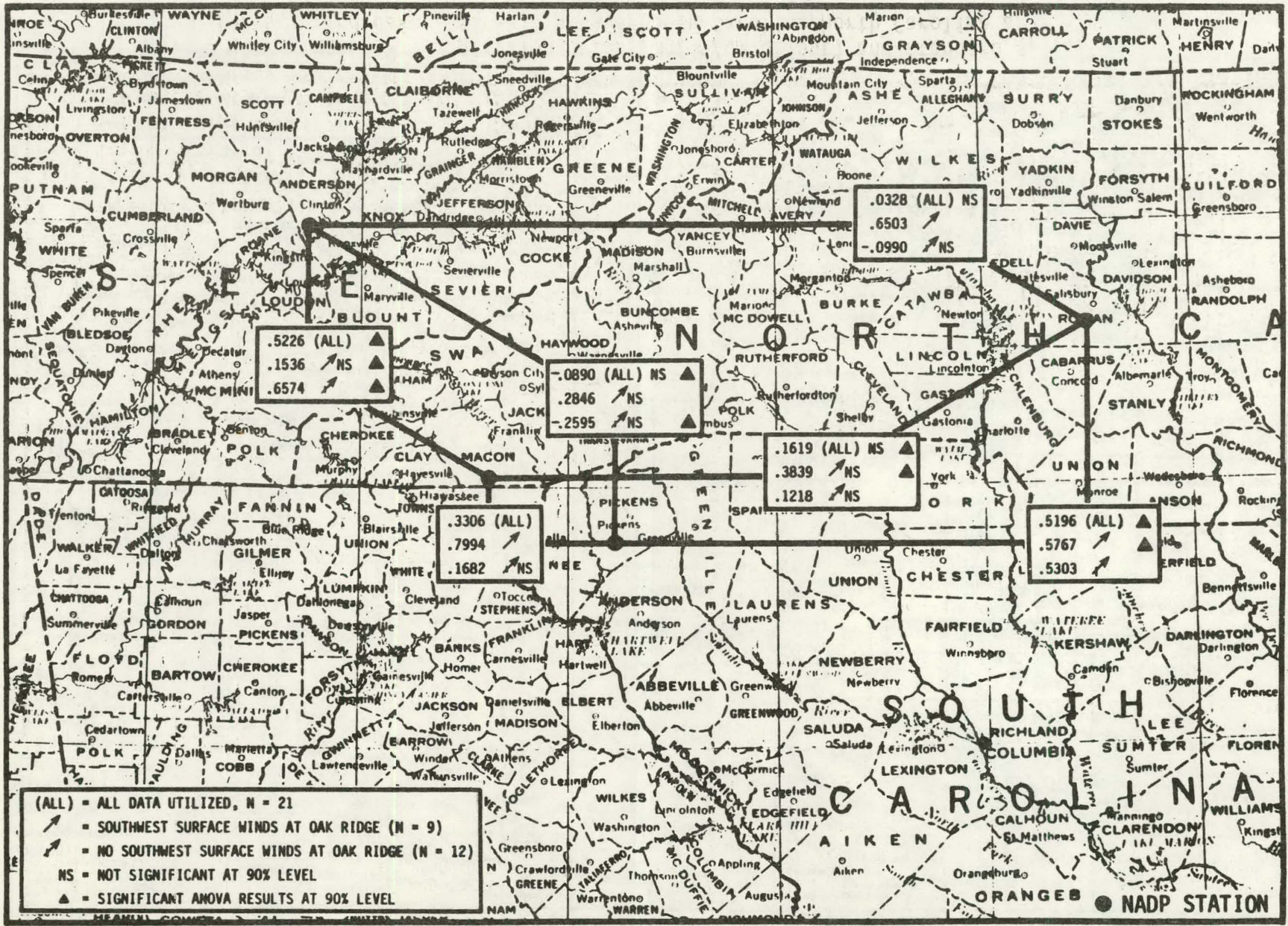

Figure A-19. Intersite correlation coefficients $(r)$ on $\mathrm{SO}_{4}^{-2}$ deposition rates $\left(\mathrm{mg} / \mathrm{m}^{2} / \mathrm{cm} \mathrm{of} \mathrm{ppt)}\right.$ for selected datc sets - Tennessee/South Carolina/North Carolina area. 


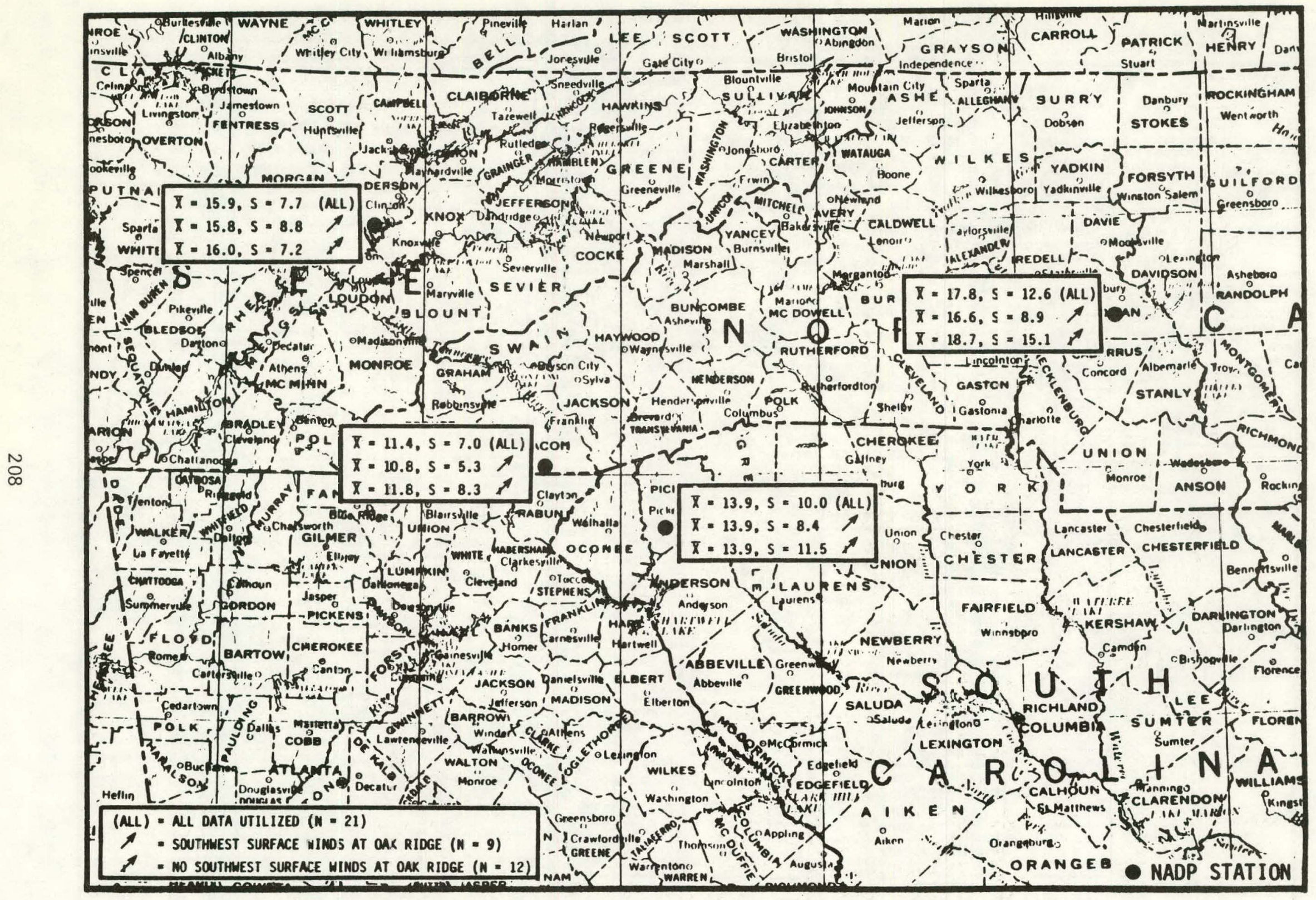

Figure $\mathrm{A}-20$. Mean $\mathrm{NO}_{3}{ }^{-}$deposition rates $\left(\mathrm{mg} / \mathrm{m}^{2} / \mathrm{cm}\right.$ of $\mathrm{ppt}$ ) and standard deviations for selected data sets - Tennessee/South Carolina/North Carolina area. 


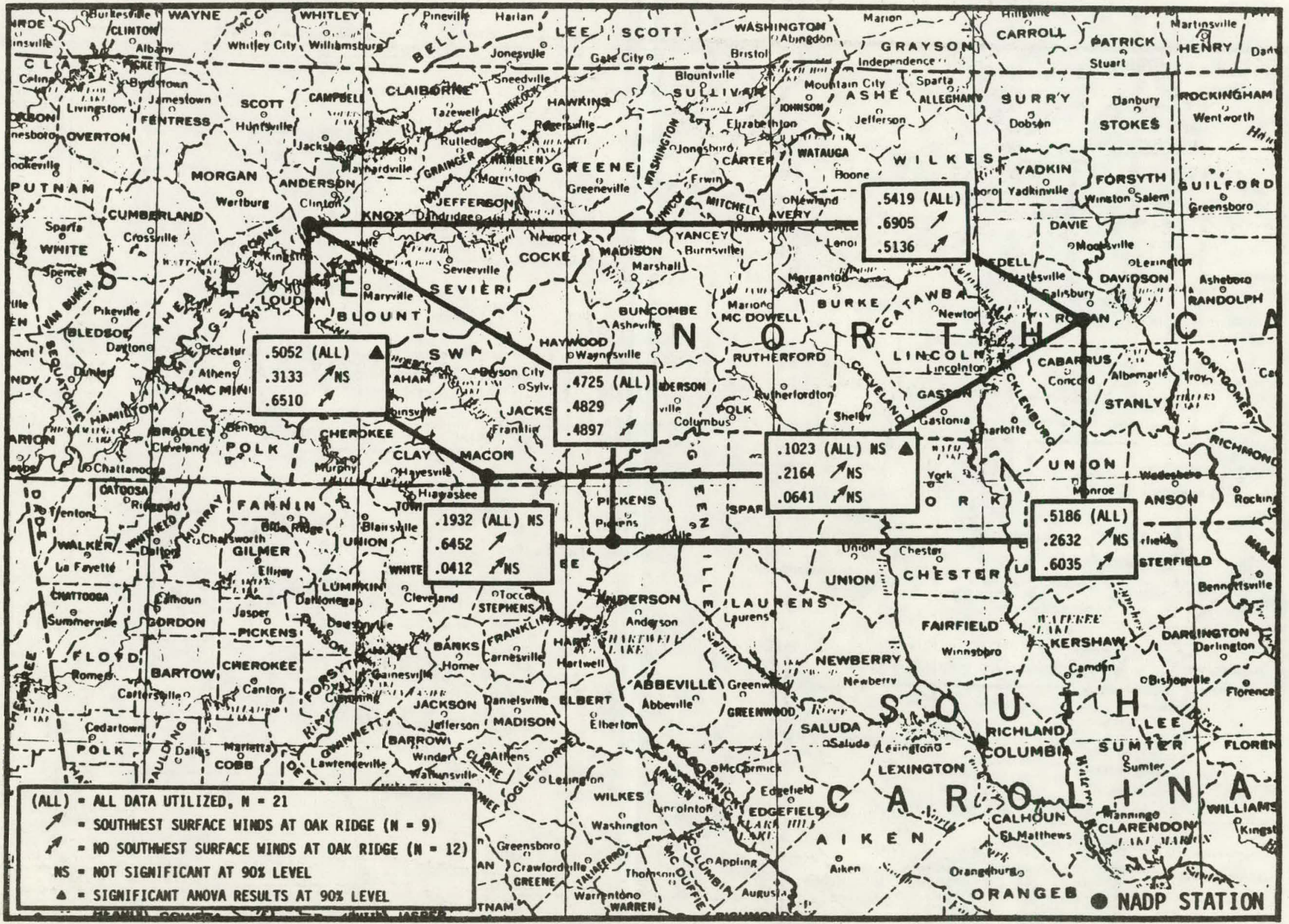

Figure A-21. Intersite correlation coefficients $(r)$ on $\mathrm{NO}_{3}{ }^{-}$deposition rates $\left(\mathrm{mg} / \mathrm{m}^{2} / \mathrm{cm} \mathrm{of} \mathrm{ppt)}\right.$ for selected data sets - Tennessee/South Carolina/North Carolina area. 


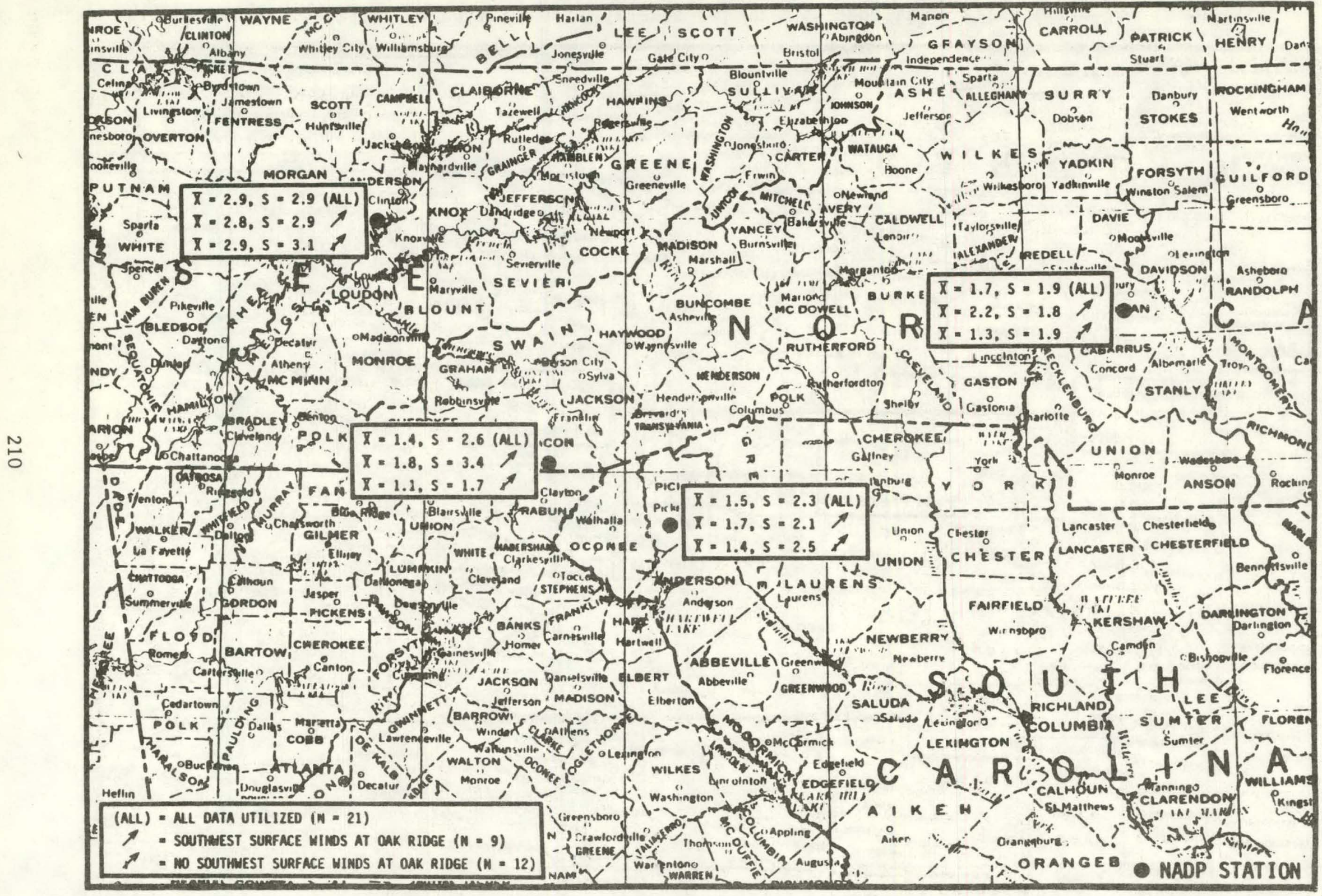

Figure A-22. Mean calcium deposition rates $\left(\mathrm{mg} / \mathrm{m}^{2} / \mathrm{cm}\right.$ of $\mathrm{ppt}$ ) and standard deviations for selected data sets - Tennessee/South Carolina/North Carolina area. 


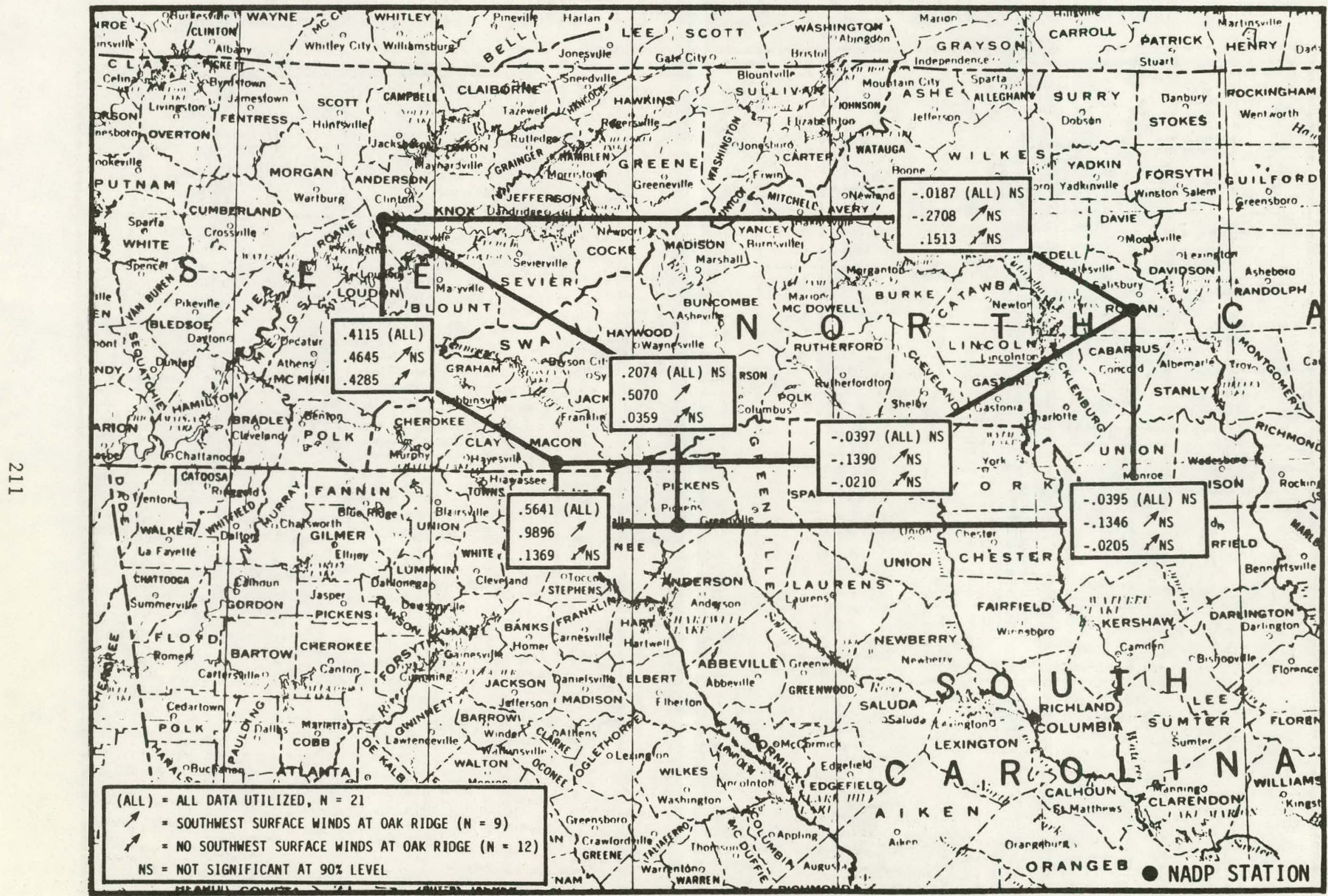

Figure A-23. Intersite correlation coefficients $(r)$ on calcium deposition rates $\left(\mathrm{mg} / \mathrm{m}^{2} / \mathrm{cm}\right.$ of ppt) for selected data sets - Tennessee/South Carolina/North Carolina area. 


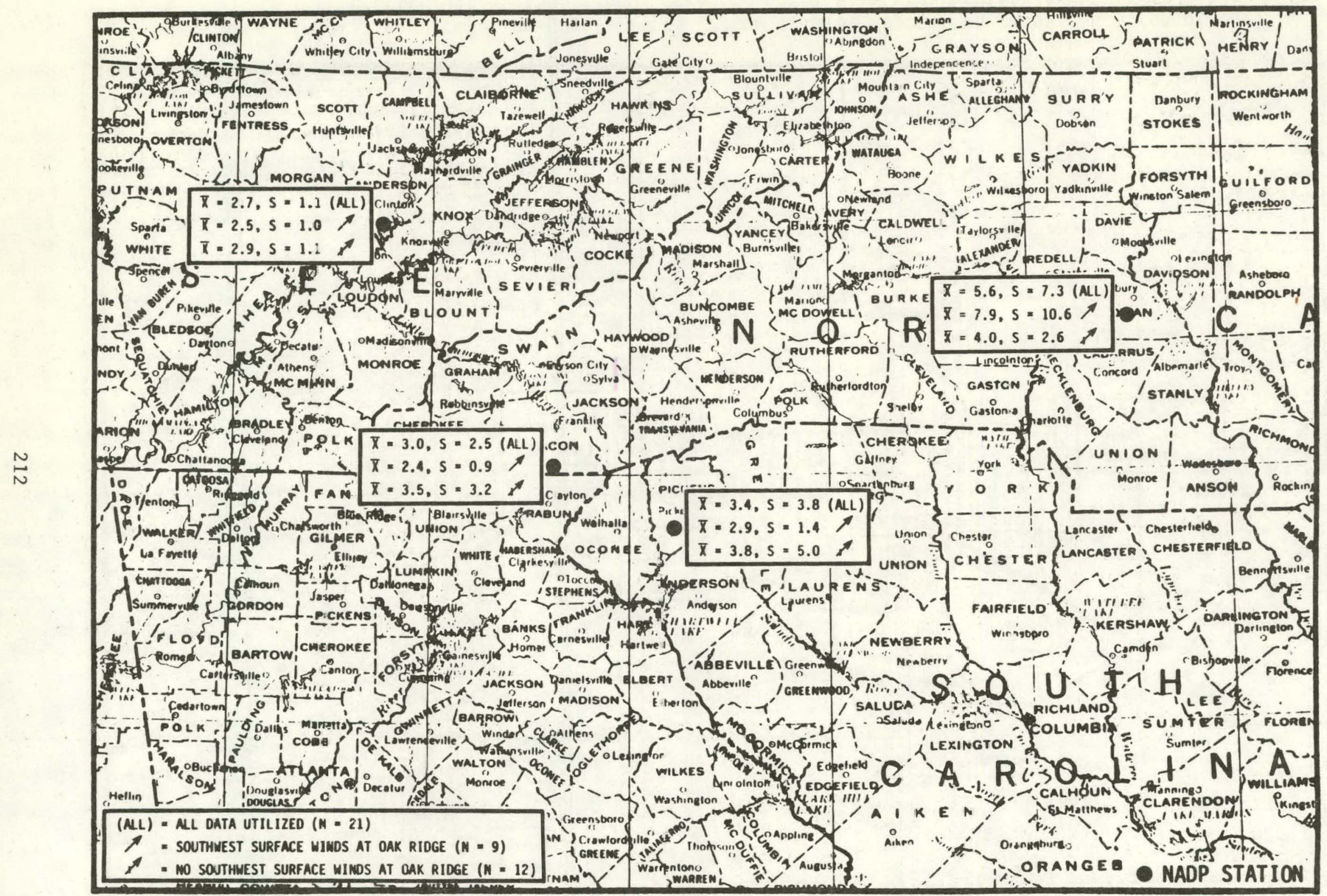

Figure A-24. Mean chloride deposition rates $\left(\mathrm{mg} / \mathrm{m}^{2} / \mathrm{cm}\right.$ of $\mathrm{ppt}$ ) and standard deviations for selected data sets - Tennessee;'South Carolina/North Carolina area. 


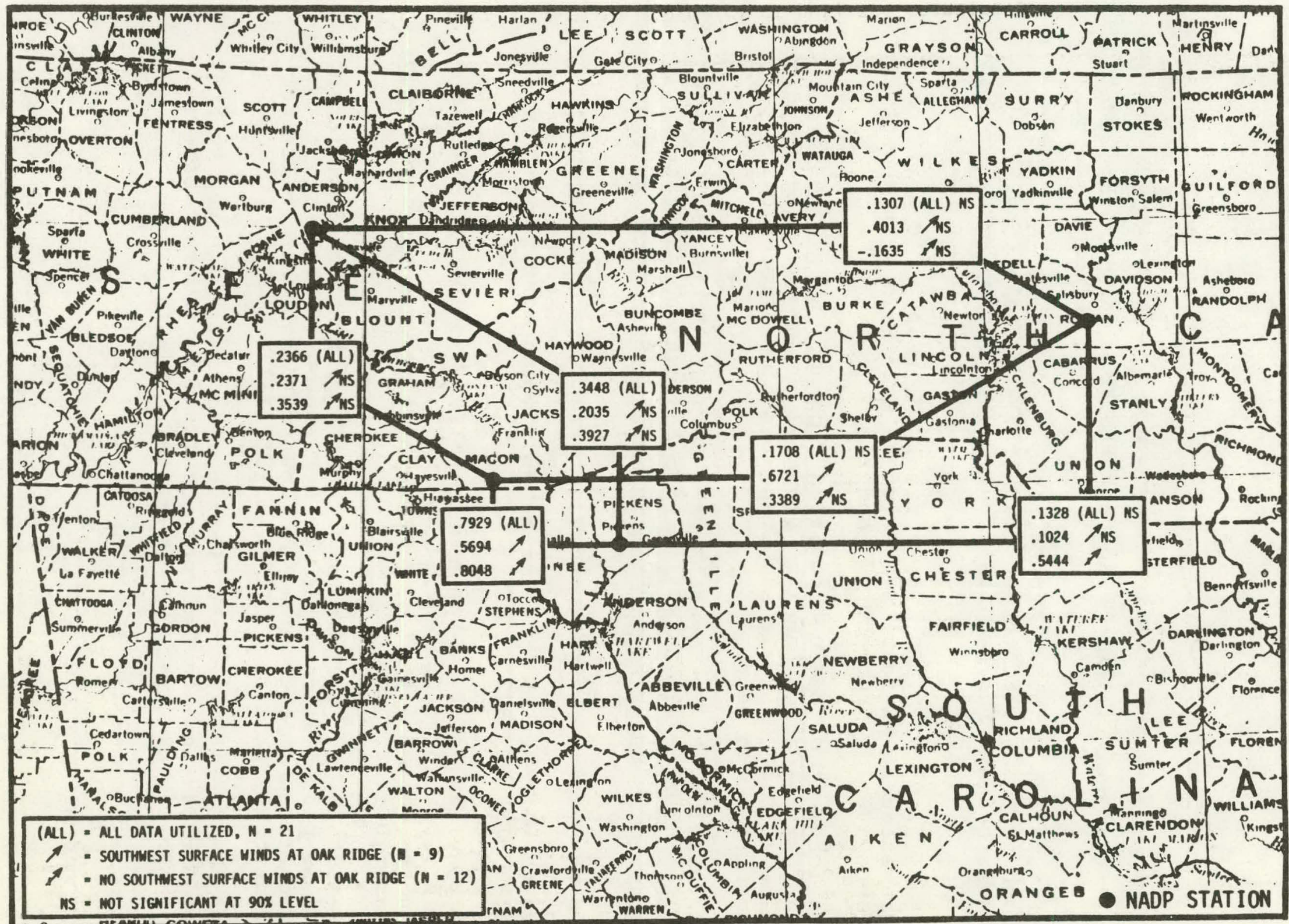

Figure A-25. Intersite correlation coefficients $(r)$ on chloride deposition rates $\left(\mathrm{mg} / \mathrm{m}^{2} / \mathrm{cm} \mathrm{of} \mathrm{ppt}\right)$ for selected data sets - Tennessee/South Carolina/North Carolina area. 
APPENDIX A REFERENCES

1. Statistical Methods, 6th Edition, Snedecor, G. W., and Cochran, W. G., Editors. Chapter 7 - Correlations. Published by the Iowa State University Press, Ames, Iowa. 1967.

2. Cogbill, C. V. 1980. Historical Geography of Depnsition. Presented at National Symposium on Acid Rain, Pittsburgh, Pennsylvania, September 23 and 24.

3. National Atmospheric Deposition Program. Site Selection and Certification Manual. Prepared by Subcommittee No. 1 Network Site Criteria and Standards of the Technical Committee, no date.

4. Altshuller, A. P. Seasonal and Episodic Trends in Sulfate Concentration (1973-1978) in the Eastern United States. Environmental Science and Technology, 14(11):1337-1398. 1980.

5. Cheng, R. T., M. Corn, and J. O. Frohliger. Contribution to the Reaction Kinetics of Water Soluble Aerosols and $\mathrm{SO}_{2}$ in the Air at PPM Concentrations. Atmospheric Environment, $5: 987-1008$. 1971 .

6. Altshuller, A. P. Atmospheric Sulfur Dioxide and Sulfate Distribution of Concentration at Urban and Nonurban Sites in the United States. Environmental Science and Technology, $7(8): 709-712$.

7. Samson, P. J., G. Neighmond, and A. J. Yencha. The Transport of Suspended Particulates as a Function of Wind Direction and Atmospheric Conditions. Journal of the Air Pollution Control Association. 25(12):1232-1237. 1975.

8. Cooper, J. A., and J. G. Watson. Receptor Oriented Methods of Air Particulate Source Apportionment. Journal of the Air Pollution Control Association. 30(10):1116-1125. 1980. 